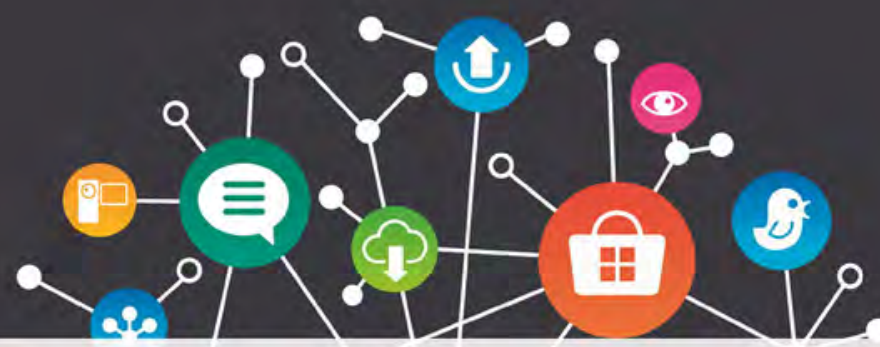

USO ÉTICO DE LA INFORIMACIÓN: IMIPLICACIONES Y DESAFÍOS

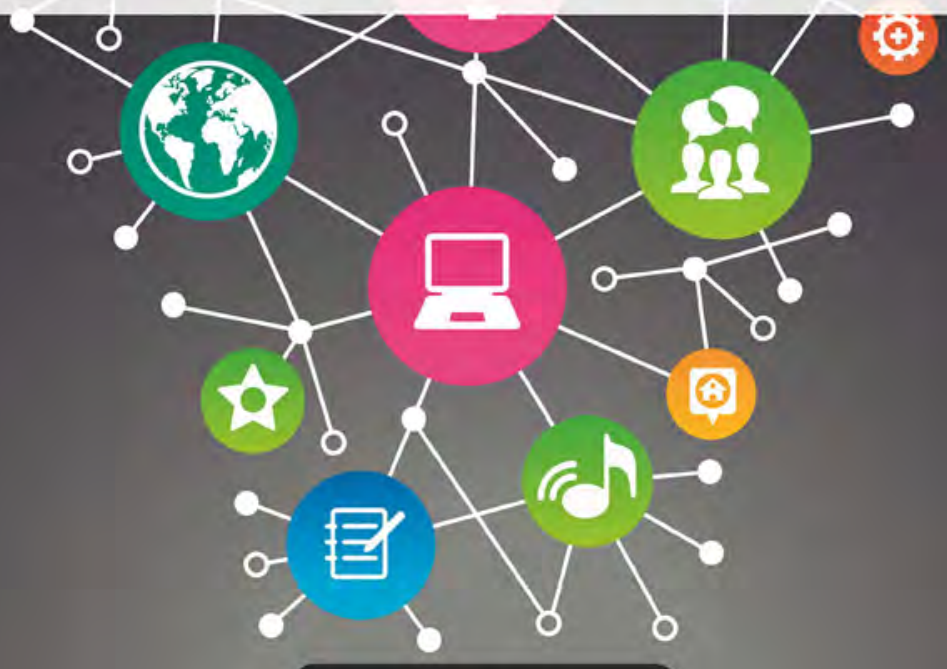

Jaime Ríos Ortega

CÉsar Augusto

Ramírez VelúzQUez

(Coordinadores)

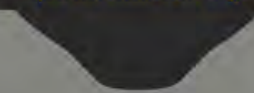




\section{La presente obra está bajo una licencia de:}

\section{http://creativecommons.org/licenses/by-nc-sa/3.0/deed.es MX}

\section{Atribución-No Comercial-Licenciamiento Reciproco 3.0 Unported}

Eres libre de:

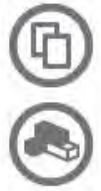

copiar, distribuir y comunicar públicamente la obra

hacer obras derivadas

Bajo las condiciones siguientes:

Atribución - Debes reconocer la autoría de la obra en los términos

especificados por el propio autor o licenciante.

No comercial - No puedes utilizar esta obra para fines comerciales.

Licenciamiento Recíproco - Si alteras, transformas o creas una obra a

partir de esta obra, solo podrás distribuir la obra resultante bajo una licencia

igual a ésta.

\section{Esto es un resumen fácilmente legible del: texto legal (de la licencia completa)}

En los casos que sea usada la presente obra, deben respetarse los términos especificados en esta licencia.
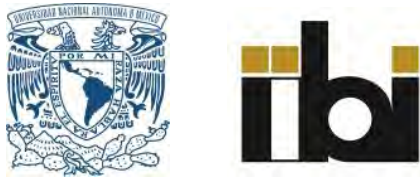


\section{Uso ético de la información: implicaciones y desafíos}




\title{
Uso ético de la información: implicaciones y desafíos
}

\author{
Coordinadores: \\ Jaime Ríos Ortega \\ César Augusto Ramírez Velázquez
}

Universidad Nacional Autónoma de México 2017 
Uso ético de información: implicaciones y desafíos / coordinadores Jaime Ríos Ortega, César Augusto Ramírez Velázquez.- México: UNAM, Instituto de Investigaciones Bibliotecológicas y de la Información, 2017.

xii, 250 p. (Sistemas bibliotecarios de Información y Sociedad)

ISBN: 978-607-02-9053-4

1. Ética profesional - Bibliotecas 2. Bibliotecología - Aspectos Morales y Éticos I. Ríos Ortega, Jaime, coordinador II. Ramírez Velázquez, César Augusto, coordinador III. ser.

Diseño de portada: Mario Ocampo Chávez

Imagen base de portada: Salvador Mendoza López

Primera Edición 2017

DR ( ) Universidad Nacional Autónoma de MÉxico

Ciudad Universitaria, 04510, Ciudad de México

Impreso y hecho en México

ISBN: 978-607-02-9053-4

Publicación dictaminada 


\section{Contenido}

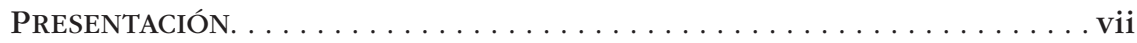
Jaime Ríos Ortega

SATISFACCIÓN DE LAS NECESIDADES INFORMATIVAS: EL USO ÉTICO

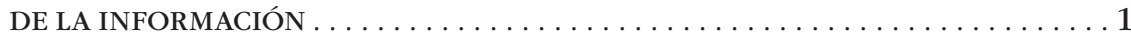

Juan José Calva González

Isabel Villaseñor Rodríguez

LA LECTURA DE LAS IMÁGENES FOTOGRÁFICAS TRAS LOS CONFLICTOS BÉLICOS: UNA MIRADA ÉTICA SOBRE LOS REFUGIADOS EN EUROPA . . . . . . . 13 Juan Carlos Marcos Recio Juan Miguel Sánchez Vigil María Olivera Zaldua

LA ÉTICA EN LAS INSTITUCIONES DE LA MEMORIA SONORA . . . . . . . . . . . 35 Perla Olivia Rodríguez Reséndiz

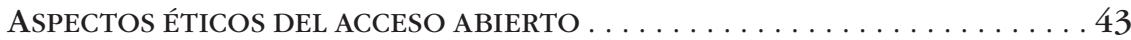
Filiberto Felipe Martínez Arellano

ÉTICA EN LAS REVISTAS CIENTÍFICAS MEXICANAS: PROCESO DE ARBITRAJE Y POLÍTICAS DE DERECHO DE AUTOR . . . . . . . . . . 61 Jenny Teresita Guerra González

LAS BIBLIOTECAS UNIVERSITARIAS ANTE LOS CURSOS MASIVOS ABIERTOS EN LÍNEA (MOOCS): ANÁLISIS DE UNA RELACIÓN POR CONSOLIDAR . . . . . . . . 85 Pedro Razquin Zazpe

DE LA "CIUDAD DE DIOS" A TELÉPOLIS. TRES TIEMPOS EN EL CONTEXTO HISTÓRICO-CULTURAL DE LA NATURALEZA ARCHIVÍSTICA . . . . . . . 117 Agustín Vivas Moreno 
DIRECTRICES PARA LA ELABORACIÓN DE PROYECTOS

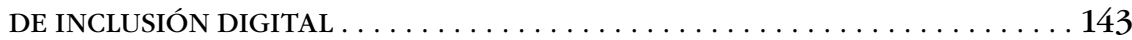

Sonia Sánchez Cuadrado

GOOGLE SCRAPING ................................. 167

Manuel Blázquez Ochando

LA INTERACCIÓN ENTRE LOS INVESTIGADORES Y LA BIBLIOTECA

PARA ESTIMULAR CONDUCTAS ÉTICAS Y EVITAR PLAGIOS

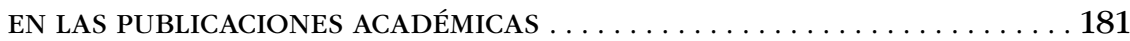

Estela Morales Campos

DESAFÍOS ÉTICOS EN LA APLICACIÓN

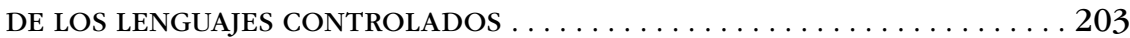

Catalina Naumis Peña

LA ÉTICA EN EL DESARROLlO DE LA CIENCIA BIBLIOTECOLÓGICA . . . . . . . 219

Rosa María Martínez Rider

Adriana Mata Puente

Eduardo Oliva Cruz

CONSIDERACIONES ÉTICAS EN EL INTERCAMBIO DE INFORMACIÓN

EN LAS REDES SOCIALES ACADÉMICAS $\ldots \ldots \ldots \ldots \ldots \ldots \ldots \ldots \ldots \ldots$

Armando Sánchez Soto

LA INFORMACIÓN DOCUMENTAL EN EL CINE. ASPECTOS ÉTICOS

Y GENERALES UNA PROPUESTA DE TRABAJO $\ldots \ldots \ldots \ldots \ldots \ldots \ldots \ldots \ldots$ José López Yepes 


\section{Presentación}

D s un hecho fácil de comprobar que, a través de la tecnolo4 gía, la inmediatez se ha vuelto un criterio que reglamenta la convivencia en la actualidad, al grado que todo lo que pensamos y hacemos está imbuido en esta urgencia. También ha sido uno de los factores que inciden en el éxito de un sinfín de ideas innovadoras que poco a poco modifican nuestro comportamiento y la forma de transmitir información en línea a nivel global; y a la par, ha sido decisivo en las prácticas deshonestas del plagio.

Los profesionales en bibliotecología, documentación y ciencias de la información de Hispanoamérica han asumido el compromiso de propugnar el respeto a la creatividad sin socavar el derecho de acceso a la información que todos los ciudadanos pueden ejercer. Lo anterior plantea una disyuntiva de significativa proporción. Por un lado, diseñan servicios bibliotecarios que tienen la encomienda de facilitar el uso de los recursos de información que se acopian en las bibliotecas; y por otro lado, la prestación de estos servicios se sujeta tanto a marcos normativos que están acordes a la legislación en materia de derecho de autor en cada país, cuya severidad escapa a los anhelos de la colectividad; así como a pautas deontológicas de los bibliotecólogos y otros profesionales que trabajan con la información. En consecuencia, el 
foco de las discusiones sobrepasa la frontera de los compromisos profesionales de los bibliotecólogos con sus comunidades, para situarse en la rigurosidad propia de las disposiciones legales en cuanto al usufructo y retribución justa por el trabajo intelectual que realizan los creadores e inventores.

En esta obra se compila una serie de reflexiones con matices éticos acerca de diversas problemáticas en el ámbito profesional. A lo largo de sus contribuciones, los autores convergen en la idea que sitúa a la ética en un horizonte al que han arribado gradualmente los bibliotecólogos por medio de diferentes puertos. Uno de estos puntos ha sido, por ejemplo, su estrecho vínculo con las instituciones que cuentan con reconocimiento social por su labor de preservación del conocimiento y de las tradiciones del pensamiento y la cultura escrita. En síntesis, los matices a los cuales se hace referencia, englobarían a las consecuencias éticas presentes en la labor cotidiana de satisfacer las necesidades de información de los usuarios, al igual que asumir los desafíos éticos en la utilización de lenguajes controlados para organizar la información. Es decir que para la vocación de servicio al público, son fundamentales los valores que promuevan la inclusión y erradiquen la discriminación por motivos de edad, orientación sexual, identidad de género, nacionalidad, afinidades políticas, estado civil, origen étnico, situación migratoria o condición social. De igual modo, se toma conciencia de los prejuicios que en determinados casos formarían parte de la terminología y expresiones lingüísticas usadas como encabezamientos de materia durante la indización de contenidos y la representación del conocimiento en épocas pasadas.

Asimismo, nuestra labor profesional también ha explorado otros ámbitos como los medios de comunicación, las instituciones de la memoria sonora o el entorno digital. Por ejemplo, podemos echar una mirada al tratamiento documental que realizan los bibliotecólogos y documentalistas sobre fotografías que suscitaron polémicas en ciertos momentos históricos. Con este ejemplo tan particular, se ve reflejada la dimensión ética en diferentes etapas: en principio, con la distribución pública de contenido sensible, seguida de 
reflexionar sobre las consideraciones requeridas para su organización y garantizar la conservación de documentos gráficos que registran pasajes abruptos de la historia, independiente de los juicios de valor que tengan los responsables de estas colecciones especiales; y que en un futuro, tendrían repercusiones en las pautas para acceder a contenido de este tipo. Lo anterior podría extrapolarse a lo que sucedería en las fonotecas de radiodifusoras, los archivos sonoros y de investigación, entendidos en su conjunto como instituciones de la memoria sonora, donde es posible hallar las más sublimes obras musicales y hasta grabaciones en audio de discursos y declaratorias en actos públicos. En consecuencia, su salvaguarda ha requerido de acciones arriesgadas en momentos de inestabilidad política y crisis. En América Latina, es desolador que han sido cruciales los testimonios registrados en formatos textuales, sonoros y audiovisuales para exigir respeto al derecho a la memoria como parte de las deudas que tienen pendientes por saldar los estados con nuestras sociedades en materia de derecho a la verdad e impartición de justicia. Además, estas injusticias sociales han dejado yermos los esfuerzos por subsanar la brecha digital que reproduce el modelo social según el cual, quienes menos tienen son los mismos que carecen de posibilidades para acceder a Internet. En este punto, nuestra postura es clara al sugerir que los bibliotecólogos deben emitir directrices metodológicas para compensar la falta de habilidades informativas y la escasez de infraestructura tecnológica que efectivamente sea de acceso público.

Otra arista de nuestra actuación y sus implicaciones éticas en el entorno digital, permanece ligada al proceso de la comunicación científica; particularmente, en la edición de las publicaciones periódicas académicas, puesto que en todas sus fases prevalece el principio de integridad académica, de acuerdo con el cual los científicos guían su conducta bajo valores como honestidad, imparcialidad, respeto y responsabilidad en pos de la búsqueda del conocimiento. Para tal propósito, los comités editoriales elaboran instrumentos normativos que deberían actualizar de manera constante y rigurosa, en virtud de perseguir fraudes científicos y desalentar malas prácticas como el plagio. Sin duda, se trata de un 
conjunto de procedimientos que se realizan a contrarreloj debido al riesgo que existe en la obsolescencia de los contenidos a publicar, o bien, en el incumplimiento de la periodicidad; lo anterior en el caso de tardar demasiado en contar con la evaluación crítica por medio del arbitraje y las modificaciones que aparezcan señaladas. Además, los juicios de valor también se hacen presentes en el mecanismo elegido para dar visibilidad a la producción de las investigaciones, a través del Acceso Abierto. Con respecto a esto, el movimiento de Acceso Abierto es una tendencia a nivel internacional que implica el acceso sin costo ni restricciones a los productos de investigación. No omitimos reiterar que este movimiento internacional se fundamenta sobre la base de una filosofía de libertad y apertura que gradualmente adquiere fuerza con el surgimiento de doctrinas políticas como el gobierno abierto o la ciencia abierta. De igual manera, el espíritu de compartir la información también se refleja en la dinámica de las redes sociales académicas. Al final de cuentas, en cualquier instancia conformamos colectividades que se sujetan a reglas de convivencia y códigos endémicos. En el caso de las de redes sociales, se tratan de aplicaciones web que ofrecen una variedad de herramientas para intercambiar y agilizar el proceso de colaboración. Sin embargo, hay malas prácticas como la usurpación de identidades, el fraude y el acoso virtual que merman la interacción provechosa.

Cabe aclarar que tanto la Web 2.0 así como el movimiento de acceso abierto, comparten principios de apertura, igualdad y libertad. Pese a interpretaciones erróneas, el movimiento de acceso abierto no ha trabado ningún conflicto con las disposiciones jurídicas que establece el Derecho de Autor. En los países hispanoamericanos se ha estipulado la existencia de los derechos morales y las facultades patrimoniales que detentan los autores de obras intelectuales. La teoría jurídica establece que éstos son inalienables, imprescriptibles, irrenunciables e inembargables; y entre los derechos morales encontramos el reconocimiento público de la autoría, o de paternidad; tienen derecho a decidir si su obra permanece inédita o la publican, o de comunicación pública; pueden 
exigir respeto a la obra y oponerse a modificaciones y mutilaciones de las que no tengan conocimiento, o de integridad; así como pueden tomar la decisión de hacer las adaptaciones de sus propias creaciones, autorizar traducciones o realizar arreglos que consideren pertinentes, o de modificación; entre otras más. Asimismo, las facultades patrimoniales que se garantizan en la mayoría de las legislaciones nacionales en materia de Derecho de Autor, se hallan: la reproducción, la distribución, la importación, la divulgación de obras derivadas de sus creaciones, la transmisión, la edición en partes y la utilización pública. En resumidas cuentas, la decisión de publicar sus productos en acceso abierto o someterlos al proceso de edición comercial, es tomada por los investigadores, sobre la base de reflexionar la viabilidad de los canales de publicación que tienen a la mano. Por una parte, publicar en acceso abierto facilitaría en cierta medida el acceso sin restricciones a sus pares en universidades que adolezcan de recursos financieros para el pago de suscripciones. Por otra parte, publicar bajo el sistema de pago por autor ofrecería la quimera de posicionar los resultados de su trabajo en canales formales y prestigiosos en el ámbito científico, y la ilusión de visibilidad internacional en su área de especialización. En ambos escenarios, la toma de decisiones compete a los autores; y el Derecho de Autor ofrece bases para respaldarlos. Por ejemplo, entre las diatribas que buscan perniciosamente socavar el Derecho de Autor se hallan señalamientos a medias de restricciones en el acceso a la información; lo cual no entra en conflicto con las facultades patrimoniales que garantizan una retribución justa por el trabajo intelectual. Es decir que se puede acceder a las obras intelectuales, toda vez que el autor reciba la compensación por su esfuerzo, como se esperaría que suceda con todos los trabajadores y la defensa de su medio de subsistencia.

Se aduce que las herramientas tecnológicas sirven para facilitar el cumplimiento de tareas, mientras que los propósitos para los cuales se empleen, a pesar de que pudieran carecer de escrúpulos, escapan por completo de pautas externas que provengan de la colectividad. Lo anterior en virtud de que caen en el territorio de 
la ética personal, la autorreflexión y el respeto que cada uno manifestemos por el otro. La plena comprensión y aprendizaje de los cambios vertiginosos de nuestro tiempo derivará hacia el desarrollo de nuestra disciplina.

Por último, el lector de nuestra obra colectiva, sin duda, hallará estos y otros temas y contará con diversos puntos de vista acerca de los argumentos que fundamentan las posturas de los autores; lo fructífero sería que el diálogo adquiera matices cada vez más interactivos y con retroalimentación de las ideas.

Jaime Ríos Ortega 


\title{
Satisfacción de las necesidades informativas: el uso ético de la información
}

\author{
JuAn José Calva González \\ Instituto de Investigaciones Bibliotecológicas y de la Información, \\ Universidad Nacional Autónoma de México, México \\ ISABEL VILLASEÑOR RODRÍGUEZ \\ Facultad de Ciencias de la Documentación, \\ Universidad Complutense de Madrid, España
}

\section{INTRODUCCIÓN}

$\mathrm{E}$ xiste una relación muy estrecha entre la satisfacción de las necesidades de información que tiene una persona y el uso que le dará o le dé a la información que cubra esa necesidad, razón por la cual el estudio o investigación sobre el uso de la información puede partir desde el momento en que la persona busca satisfacer su necesidad informativa, ya que es muy posible que ya tenga en mente el uso que le dará a la información obtenida y decidirá si le dará el reconocimiento a la fuente de donde la obtuvo, pero esto dependerá del uso que le dé. Es indiscutible que si es un uso académico, la fuente de donde se obtuvo la información utilizada es importante. Entonces hay que buscar esa relación entre la satisfacción y el uso de la información.

\section{EL USUARIO DE LA INFORMACIÓN}

Tomando en cuenta lo expresado por diversos autores y tratando de llevar a cabo una síntesis de sus propuestas, se puede establecer la siguiente tipología de usuarios: 
1. Por el uso que hacen de alguna unidad de información (centro de información, documentación, biblioteca, archivo, etc.).

- Usuarios potenciales, que tienen el derecho de usar el centro aunque no lo hacen.

- Usuarios reales, que, aunque no siempre tienen derecho a usarlo, pueden ser:

- Presenciales, que usan el centro en el mismo centro.

- No presenciales, que usan el centro fuera del centro (los presos, los enfermos, los usuarios virtuales, etc.).

En relación con este criterio, hay que considerar el asunto de la frecuencia y de la finalidad con que usan la unidad de información y la información que obtienen.

2. Por la edad:

- Usuarios infantiles.

- Usuarios juveniles.

- Usuarios adultos, con especial atención a la tercera edad.

3. Por el tipo de centro de información que usan:

- Usuarios de bibliotecas públicas o privadas, generales o especializadas, de apoyo a centros docentes (escolares: alumnos, profesores, padres; universitarias: alumnos de distintos ciclos, PAS) o a entidades superiores (museos, archivos, ministerios, empresas, parlamentarias, etc.).

- Usuarios de archivos:

- Internos.

- Externos.

- Usuarios de centros de documentación especializados públicos o privados, internos o externos.

- Usuarios de centros de información electrónicos o híbridos:

- Iniciados y autosuficientes.

- Que saben poco o nada y dependen del profesional de la información.

- Virtual. 
4. Por competencias, habilidades y conocimientos para manejar la documentación, esto es, su destreza en relación con el grado de alfabetización en información:

- Mayor o menor grado de destreza.

- Menor o mayor dependencia del profesional de la información.

5. Usuarios por el tiempo y material requeridos para satisfacer las demandas así como por el grado de satisfacción en relación con la respuesta recibida.

6. Usuarios por distintos condicionantes que determinan la capacidad para acceder a la información:

- Económico-sociales: grupos de población más desfavorecidos.

- Culturales: comunidades indígenas, por lengua.

- Ocupación: trabajadores (fuera y dentro de casa), en paro, estudiantes, jubilados.

- Nivel de formación: sin estudios, con estudios (primarios, secundarios, superiores).

- Físicos (alguna discapacidad).

- Geográficos (cercanía o lejanía del centro).

En la actualidad, se puede hablar del Usuario 2.0, término que ofrece tantos perfiles como individuos diferentes navegan por Internet. En este caso, lo que importa no es tanto el individuo sino la comunidad de la que forma parte, ya que éste es uno de sus rasgos característicos. Hasta el momento, son escasos los trabajos de carácter teórico que afronten una tipología de Usuarios 2.0. En la bibliografía consultada se ha podido ver algunas clasificaciones y caracterizaciones de usuarios en la red fundadas esencialmente en resultados obtenidos a través de trabajos de campo. Así, Reig (2009) da a conocer una tipología basada en aspectos relacionados con las actitudes y conductas de los usuarios de redes sociales que, en su día, estableció OFCOM. ${ }^{1}$ Se puede encontrar:

1 Organización reguladora independiente para las industrias de la comunicación en Reino Unido. 
- Alpha socializers: personas que usan los sitios sociales en intensos y cortos periodos de tiempo para coquetear, conocer gente nueva o entretenerse.

- Buscadores de atención: personas que buscan la atención y los comentarios de los demás, posteando fotos y personalizando sus perfiles.

- Seguidores: personas que se unen a sitios sociales para estar al día de las actividades de sus contactos en la vida real.

- Fieles: personas que usan las redes sociales para recuperar amistades del pasado.

- Funcionales: gente que tiende a usar los sitios de redes sociales con un único objetivo, puntual.

- No usuarios: pueden clasificarse en distintos grupos, según las razones que se aducen para no utilizar redes sociales como la preocupación por la seguridad, la poca experiencia técnica o motivos intelectuales al suponer las redes sociales como una pérdida de tiempo.

Por su parte, Barbosa et al. (2010), al considerar la red como nuestro territorio nuestra aldea global, distinguen una gran diversidad de pobladores en ella, entre los que destacan:

- Nativos digitales.

- Inmigrantes digitales.

- Fóbicos digitales.

Por último, Rautenstrauch (2011) dice que, en las redes sociales, se puede clasificar los usuarios en los siguientes perfiles, según su participación en los medios sociales:

- Creador.

- Conversador.

- Crítico.

- Coleccionista.

- Participativo. 
- Espectador.

- Inactivo.

LA SATISFACCIÓN DE LAS NECESIDADES DE INFORMACIÓN DEL USUARIO

Los usuarios, cualesquiera que estos sean, pasan por el ciclo de las necesidades de información, el cual consta de tres partes fundamentales: el surgimiento de la necesidad de información, el comportamiento informativo y la satisfacción.

Es indudable que el largo camino para la satisfacción de las necesidades de información no es fácil, ya que no siempre se cubren sino que, a veces, lo que se consigue es la insatisfacción. Ambas vertientes tienen un impacto en el usuario. Si vemos el surgimiento de estas necesidades y su manifestación a través del comportamiento informativo que lleva al individuo a buscar la satisfacción. Por lo cual, todo sujeto, a través de su comportamiento informativo, busca resolver sus necesidades de información. Esta búsqueda es constante en nuestra sociedad actual y en las diversas comunidades de sujetos. Entonces, los sujetos buscarán cualquier medio (recurso o fuente) a su alcance para sentirse satisfechos informativamente. La satisfacción se enmarca dentro de la teoría de las necesidades de información y se entiende como el restablecimiento del equilibrio del sujeto con su medio circundante, a partir de disipar las carencias de conocimiento e información que tenía sobre un hecho, objeto o fenómeno y que fue lo que provocó una necesidad de información.

Para satisfacer las necesidades de información, una persona presenta un comportamiento informativo, como por ejemplo: consultar a sus vecinos, ir a la biblioteca, dirigirse a un servicio de información o valerse de su experiencia.

Entonces, el sujeto espera sentirse satisfecho al tener cubiertas sus necesidades de información. Esto lo logra obteniendo los documentos (satisfacción material) con la información que necesita; asimismo el individuo tendrá una satisfacción emocional cuando 
usa la información obtenida con el fin para el cual la necesitaba, lo que también repercutirá en su comportamiento informativo posterior - cuando presente otra nueva necesidad informativa al transcurrir el tiempo. De la misma manera, si no se obtiene satisfacción, lo emocional estará cargado de una serie de sentimientos en el sujeto, lo cual también afectará su comportamiento futuro con relación a las nuevas necesidades que tenga.

Visto así, es posible establecer como fundamento que el sujeto es el único que puede determinar si está satisfecho en cuanto a sus necesidades de información.

Lo anterior sugiere pensar en las características que deben tener dichas fuentes y recursos de información. Pero la valoración o evaluación de las fuentes y recursos las proporciona el propio sujeto. Es indudable que si él está satisfecho, es porque la fuente o recurso también fue pertinente, relevante y precisa.

En la satisfacción de usuarios hay que reconocer, como señala Figuereido, que "[...] los canales informales son considerados importantes para satisfacer muchos de los tipos de necesidades de información que tienen los sujetos de una comunidad" (Figuereido 1994, 27). Es así como se abre la conversación con colegas u otras personas, expertos, profesores, maestros, parientes, etc., sobre la búsqueda de la información registrada en algún documento impreso o electrónico.

La información que satisfizo al sujeto, es decir positivamente, será utilizada por éste y formará parte de su experiencia acumulada; será una parte más de ese gran cúmulo que podrá seguir utilizando en otros momentos, ya que ha quedado registrada.

\section{EL USO DE LA INFORMACIÓN}

El usuario, para satisfacer su necesidad de información, deberá darle un uso específico a la información obtenida, ya sea sólo para adquirir el conocimiento que le hace falta sobre algún hecho o fenómeno, o bien para utilizarlo en forma práctica: elaborar una conferencia, apoyar el diseño de equipo o instrumentos, preparar 
Satisfacción de las necesidades informativas...

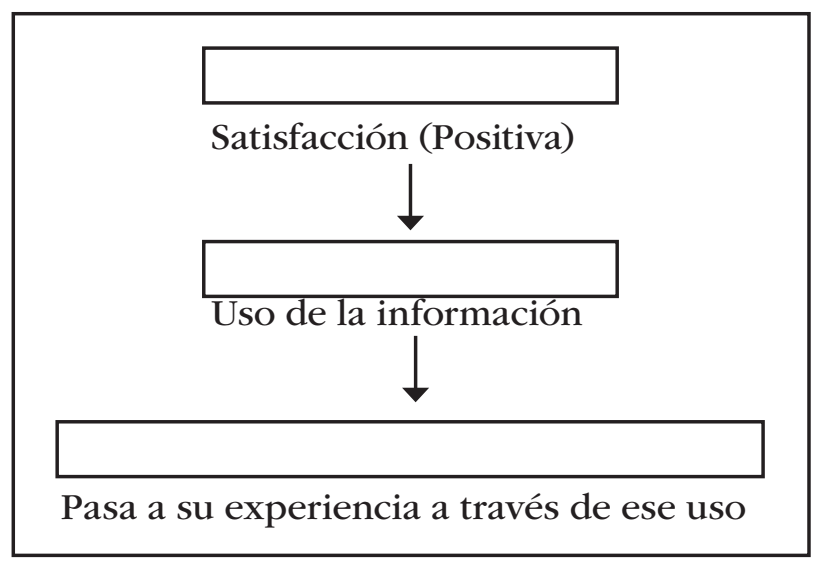

Fuente: Elaboración propia

una clase, solventar un problema personal con su familia o amistades, etc.

Así es como el uso de la información estará determinado por lo que el usuario pretende hacer con ella en el momento que la obtiene, de ahí se acepta que su uso forma parte de los factores internos que orillan al sujeto a tener una necesidad.

También es importante señalar que el uso de la información tendría un lugar bivalente, es decir, estará presente al momento de la satisfacción de la necesidad de información, ya que está relacionado con la valoración positiva o negativa al momento en el que el usuario pueda hacer uso de ella. Pero, a la vez, forma parte de los factores internos que impactan al propio usuario, ya que, en el momento de originarse la necesidad de información, este elemento es un factor interno que impacta en la propia necesidad, ya que el sujeto tendrá una idea de cuál será el uso que le dará a la información una vez obtenida.

Asimismo, el uso de la información obtenida le permitirá al usuario restablecer el equilibrio y satisfacer la necesidad que tenía. Pero el usuario deberá comprender que el uso de la información, es decir las practicas éticas en su uso para las labores de investigación implican: 
En primera instancia, comprender el impacto social y económico que tiene la investigación y sus productos y, por lo tanto, el uso que se le da a la información generada de ella.

En segundo lugar, tomar en cuenta la normatividad acerca del acceso a la información, sobre todo a la información de acceso libre y que se encuentra en formato electrónico en Internet.

En tercer lugar, utilizar responsablemente las fuentes de información y reconocer a los autores que las escribieron.

En cuarto lugar, el acceso a la información, aunque parezca que es gratuito, alguien lo está cubriendo, sobre todo si es de acceso libre en Internet, alguien está pagando por el servidor o el lugar donde se ubica la fuente original, el libro ubicado en una biblioteca conlleva un costo para poder prepararlo para tener acceso libre al mismo (como en la biblioteca pública o universitaria, por ejemplo). El servicio de préstamo interbibliotecario también conlleva un costo para ambas bibliotecas que están en convenio, aunque el usuario no lo perciba directamente.

En quinto lugar, la citación, reconocer de quien es la información que se obtuvo. El copiar y pegar o el copiar literalmente parte de un texto impreso o electrónico representa una práctica o un comportamiento antiético. Esta práctica puede estar penalizada o presentar sanciones. Para conseguir un comportamiento ético en el uso de la información es preciso reconocer las ideas de otros, plasmadas en algún soporte de información y citarlos.

\section{REFLEXIONES ÉTICAS SOBRE EL USO DE LA INFORMACIÓN}

Hacer una investigación sobre el uso que le dan a la información las personas, a partir de los estudios sobre satisfacción de las necesidades de información de los usuarios, podrá permitir hacer la conexión entre satisfacción y el uso ético que el usuario le dará a la información que le cubre su necesidad informativa.

Ahora bien, el profesional de la información como el bibliotecólogo, documentalista o archivista tendrá que investigar sobre el uso que le dará a la información que se le proporciona en al- 
guna de las unidades de información: biblioteca, archivo, centro de documentación, o que obtuvo de forma directa con una fuente informativa o electrónica al tener acceso abierto a los documentos electrónicos.

Esta reflexión por si misma nos lleva a investigarla en el momento en que un usuario solicita la información en una unidad de información. De esta manera se podrá empezar la investigación de su uso, así el usuario puede decir que la quiere para hacer un artículo, un libro, para una investigación o simplemente porque necesita saber y cubrir un conocimiento que no tiene en ese momento, o bien no dar demasiadas explicaciones al respecto; entonces surge la inquietud de cómo puede transmitirse la idea de que el usuario tiene que hacer un uso ético de la información una vez que se las entregaron, es decir, tomar en cuenta la fuente de donde la obtuvo, posiblemente citándola, indicando de quién tomó los datos y sobre todo considerar para qué la está utilizando, si es para llevar a cabo una acción académica, una acción de servicios u otra acción específica. Sin embargo, podría usarla para un hecho negativo y la información le sirvió para hacer una acción perjudicial para un individuo, la comunidad o la sociedad.

El uso ético de la información que se proporciona en las unidades de información, debe investigarse desde este contexto: qué uso le dará y cómo debe usarla.

Con la aparición del acceso abierto a la información que se encuentra en Internet, el sujeto ya no asiste a la biblioteca a solicitarla, entonces una vez que consigue la información debe usarla en forma ética y con responsabilidad. Puede ser para su beneficio propio o para el de su entorno social, pero bien puede usarla de una forma no ética o puede copiarla sin darle crédito a la fuente en Internet de donde la obtuvo.

El profesional de la información debe, de alguna forma, darle la información al usuario sobre el uso ético de la información que le fue proporcionada, ya sea de forma impresa o electrónica, o bien de una fuente directa y a través del acceso abierto que es un derecho, y de los documentos electrónicos, que ya se encuentran libres en el Internet. Por ejemplo, en la UNAM todos los productos 
generados por las actividades de docencia e investigación se encaminan a estar en formato electrónico de libre acceso.

\section{CONSIDERACIONES FINALES}

En la época actual y con el aumento de acceso a la información electrónica que se ubica libremente en el Internet, es preciso investigar cómo los usuarios de toda esa información la usarán de forma ética, y que su conducta cumpla con un código, es decir, con el uso que dé a la información obtenida.

El uso ético de la información se refiere a cómo es usada con respecto a cómo la usan los demás, es decir, toda una comunidad, como lo puede ser la académica. El uso ético puede tener presente una serie de normas, reglas o códigos que guían la conducta de una comunidad de usuarios de la información.

Asimismo, hay que reflexionar acerca del uso que le da una persona, un usuario, a la información que obtiene de una biblioteca o de un archivo, o de la que se encuentra libre en Internet como, por ejemplo, los componentes para elaborar un aparato explosivo con componentes caseros o fáciles de adquirir y que esta información la obtuvo de cualquier recurso impreso o electrónico que tenía disponible.

\section{BibliografíA}

Barbosa, D., A. Vázquez, J. Seco, J.M. Jiménez (2010). CULTURA 2.o. Técnicas de investigación en entornos digitales. Barcelona: UOC.

Figuereido, N. Menezes de (1994). Estudos de uso e usuários da informação. Brasilia, Ministeiro da Ciencia e Tecnologie: IBICT. 
Rautenstrauch, R. (2011). Tipos de usuarios en Redes Sociales. Disponible en: <www.netconsultingmarketing. es/tipos-de-usuarios-en-redes-sociales/> [Fecha de consulta: mayo 2016]

Reig, D. (2009). Actitudes, comportamiento, usos, clasificación de los usuarios de las redes sociales. Disponible en: <http://www.dreig.eu/caparazon/2009/02/09/ actitudes-comportamiento-usos-clasificacion-de-losusuarios-de-las-redes-sociales/> [Fecha de consulta: mayo 2016] 


\title{
La lectura de las imágenes fotográficas tras los conflictos bélicos: una mirada ética sobre los refugiados en Europa
}

\author{
Juan Carlos Marcos Recio \\ Facultad de la Información, Universidad \\ Complutense de Madrid, España \\ JuAN Miguel SánChEZ VigiL \\ María Olivera ZalduA \\ Facultad de Ciencias de la Documentación, \\ Universidad Complutense de Madrid, España
}

\section{INTRODUCCIÓN}

$\mathbf{N}$

unca antes desde la Segunda Guerra Mundial, Europa había vivido un fenómeno migratorio tan numeroso, a raíz de conflictos bélicos en diversos países musulmanes que han visto en el Viejo Continente el sueño de establecerse, aunque tengan que enfrentarse a una nueva cultura, lengua, religión, política y educación. Según un Informe de la Comisión Española de Ayuda al refugiado, se trata del mayor éxodo desde la Segunda Guerra Mundial. Si bien toda guerra supone un desplazamiento de los perdedores, el año 2015 ha sido especialmente intenso en cuanto al número de personas que, atravesando Turquía o bien pasando por Grecia, han apostado por Europa como lugar donde quieren empezar una nueva vida, antes lo era a través del Estrecho de Gibraltar hacia España.

Este éxodo es fruto de una intolerancia de los gobernantes de determinados países, apoyados por fuerzas internacionales que no respetan los derechos humanos y que quieren perpetuarse en el poder, incluso en contra de los ciudadanos para los que gobiernan. Enfrentamientos religiosos entre diferentes etnias son la excusa, a veces, para afrontar problemas económicos de algunos 
gobernantes que resuelven sus malas gestiones enfrentando a una parte de los ciudadanos con otra.

Está en el ADN del ser humano iniciar caminos que conducen a otros lugares. Así, desde Marco Polo con sus viajes hacia Asia, pasando por los conquistadores españoles y portugueses, los navegantes holandeses e ingleses e, incluso en la época del imperio francés, fueron los que establecieron contacto con otras civilizaciones. Este tipo de encuentros, no siempre amistosos, como se puede constatar en las crónicas de la historia, dio origen a nuevos mestizajes entre las culturas. Eran desplazamientos voluntarios paraencontrar otras maneras de establecerse y empezar nuevas vidas. En cada uno de los imperios citados con anterioridad, hubo un flujo de personas entre la metrópoli y la colonia del que se beneficiaron ambos países.

Esa realidad se fue suplantando cuando la brecha económica se hizo más fuerte, y los países más ricos, temerosos de la llegada de más inmigrantes, deciden poner leyes que restrinjan la entrada de nuevos ciudadanos. Mientras, en los países más desfavorecidos, el nivel de pobreza siguió creciendo y con él la necesidad de que sus ciudadanos buscaran mejores formas de vida marchando hacia el norte geográfico. Esto es lo que ha sucedido en la última década y, especialmente en el año 2015, cuando miles de ciudadanos huyen de países asolados por las guerras, especialmente, Irak, Libia y Siria. Pero hay otras emigraciones que se vienen estableciendo con regularidad, del Sur de América y Centroamérica queriendo cruzar la frontera mexicana rumbo a Estados Unidos y Canadá, también en busca de otra forma de vida. En el siglo XX se constata otra realidad diferente, sobre todo las dos guerras mundiales ( $1^{\mathrm{a}} \mathrm{GM} 1914-1918$ y $2^{\mathrm{a}}$ GM 1940-1945) donde Europa sumó miles de desplazados de un país a otro más próximo geográficamente.

En el caso español, la emigración de finales del siglo XIX sirvió para que algunos se desplazaran a las colonias con la esperanza de encontrar una vida mejor; y hubo otra hacia el centro y norte de 
Europa en los años 60 y 70 también en busca de trabajo y un mundo mejor. Tras 40 años hemos pasado de un país que emigra a un país que recibe a otros ciudadanos, con una problemática especial a lo largo de la última década, ya que desde el norte de África han venido oleadas de emigrantes centroafricanos con el fin de establecerse después en países del norte de Europa, tomando como paso el suelo español.

Este trabajo tiene como objetivo estudiar las imágenes fotográficas que se originan tras los conflictos bélicos, cómo leerlas e interpretarlas y cuál es el tratamiento que los medios de comunicación hacen de la llegada de los refugiados a Europa. En este sentido, los medios de comunicación han jugado un papel fundamental dando a conocer las difíciles situaciones en las que llegaban los emigrantes a Europa y los que se quedaron en el intento, de los que no hay cifras. Y de manera particular hay algunas fotografías que se grabarán para siempre en la memoria del ser humano como símbolo de una tragedia, algo que se debería haber evitado y que no se hizo.

Conflictos BÉLicos CAUSANTES DE UNA EMIGRACión DESCONTROLADA

La mayoría de los conflictos bélicos que han sucedido en la última década, o quizás desde la Guerra de los Balcanes en suelo europeo, han significado un aumento considerable de los desplazamientos entre los países europeos. Además, la situación geopolítica en algunos países de la zona del Golfo Pérsico, han roto el mapa político que existía, también el territorial, y han expulsado de varios territorios a un elevado número de personas que esperan ser acogidas en Europa.

Durante los últimos cinco años, los medios de comunicación estuvieron interesados en esos conflictos. La información textual y gráfica se cubría en la zona. Había un conocimiento directo de lo que estaba sucediendo en esos lugares. La televisión también ofrecía imágenes desgarradoras de situaciones familiares en las 
que muchas personas salían de su ciudad al quedarse sin casas destruidas por la guerra. Pero esa información cambió cuando las facciones militares, religiosas y/o políticas decidieron que los periodistas serían los primeros en ser ejecutados. Hasta entonces, la vida de los periodistas, tras un secuestro y quizás un pago por el rescate, continuaba en otra zona mandando información. Este proceso se rompió porque se dejó de negociar en la mayor parte de las ocasiones y, por eso, según el Barómetro de la Libertad de Prensa de Reporteros sin Fronteras en el año 2014 resultaron muertos 71 periodistas, 11 colaboradores y 21 ciudadanos (64/6/19, en 2015). Por tanto, la información gráfica de las agencias, y el texto que llega de estas zonas es cada vez menor y la realidad que se cuenta no es la misma que si el periodista o el fotógrafo estuviera en la zona.

Por tanto, cabría preguntarse: ¿Qué está pasando en estos países para que los ciudadanos tengan que salir a toda prisa? ¿Cuántos y de qué zonas están llegando a Europa? ¿Qué está pasando en otras partes del mundo que ahora afectan a Europa? Respondiendo a estas cuestiones podremos centrar este trabajo y pasar luego a evaluar la información y las fotografías en algunos medios.

¿Qué está pasando en estos países para que los ciudadanos tengan que salir a toda prisa?

Son varios los problemas de los países que terminan en un conflicto, desde la intolerancia religiosa que enfrenta a comunidades, dos en el mundo musulmán: chiies y suníes, pasando por los problemas económicos derivados del descenso de sus recursos naturales, o simplemente, la mala gestión de sus dirigentes, que se perpetúan en el poder obligando a una parte de sus ciudadanos a tener que emigrar ante las dificultades en las que se quedan. Geopolíticamente estos países en conflicto han pasado de estar aliados a Occidente, quien les ha entrenado militarmente y les ha dotado de armas, a ser enemigos principales. En ese cambio, algunas facciones militares se han quedado con importantes partes de un territorio, como es el caso del DAES (ISIS por sus siglas en inglés) que ocupa ya importantes espacios en Irak, Libia y Siria. 
Si bien, Siria es el ejemplo más reciente, desde los años 80 del siglo pasado, se vienen acumulando exiliados por tres guerras importantes: Vietnam, Afganistán e Irak. Por su parte, el continente africano produjo importantes desplazamientos de un país a otro por culpa de guerras como las vividas en Angola, Sudán, Burundi, República Democrática del Congo, Eritrea, Ruanda, Somalia y hasta el Sáhara Occidental. En todos estos casos, la primera opción de los refugiados es ir al país más próximo. Así, en el caso de Siria, países como Líbano, Jordania, Turquía, Irak y Egipto fueron al principio sus opciones. Pero viendo que esos países tampoco garantizaban su seguridad, el efecto llamada de otros vecinos o familiares empujó a muchos a salir de los campos de refugiados y desplazarse a Europa.

Conviene precisar una diferencia entre lo que significa ser migrante y/o refugiado. En el primer caso, se hace por cuestiones económicas y con el fin de encontrar una mejor vida en otro país, con otra sociedad y otra cultura; en el segundo, se hace porque desean salvar su vida y preservar su libertad. Es su estado el que los persigue e incluso condena a muerte por lo que tienen que desplazarse y solicitar asilo político en otro donde les garanticen su seguridad. Por tanto, no son solo cuestiones económicas las que obligan al refugiado a irse a otro país, la religión y sobre todo la política les lleva a emigrar porque su gobierno les considera enemigos peligrosos.

\section{¿Cuántos y de qué zonas están llegando a Europa?}

Curiosamente, Europa acoge cada año más de 500 millones de turistas, de ellos 89 millones visitaron Francia y 60 España en 2013. El resto se reparten en otros países, fundamentalmente Inglaterra, Italia y países nórdicos. Pero, mientras el turismo genera riqueza a estos países, los emigrantes y los refugiados suponen una carga social y económica que en algunos casos supone un impulso de generosidad y solidaridad fugaz.

Los datos que se pueden manejar en este trabajo varían de un día para otro, dependiendo del flujo, pues hay días que llegan 
2000 nuevos refugiados, otros 600 y días con apenas un grupo pequeño en barcos con poca capacidad. La Comisión Europea, alertada por los miles de desplazamientos que llegaban a Europa, sobre todo a través de Grecia y de Turquía, opta por un reparto del que ni siquiera se han puesto de acuerdo las partes. El cupo de refugiados dispuestos a recoger de manera consensuada por este organismo se eleva a 120 000, número muy inferior al volumen real de personas que siguen llegando a Europa. De esa cantidad barajada, 17800 serían las que tiene que asumir España. Pero los datos son estremecedores. De la cantidad total, tan solo se han realojado oficialmente a 272 personas, 18 de ellas en España. Y lo peor de todo, según ha denunciado UNICEF es la desaparición de unos 10000 niños que pueden haber caído en mafias en donde serán explotados. En definitiva, el sistema europeo de asilo no está actuando a la altura de las necesidades, porque algunos países de la Eurozona están atravesando momentos económicos difíciles y por ello están blindando sus fronteras con la construcción de alambradas, edificando muros (similar al que Estados Unidos construye con México) y poniendo al ejército en la frontera para que entre en su país; o el que separa Israel de Palestina.

La gran avalancha de refugiados se ha producido sobre todo por la guerra en Siria, que comenzó en el 2011 y continúa en la actualidad por motivos de violación de los derechos humanos, pobreza, desigualdad, secuestros políticos, etc. y que a comienzos de 2016, suponía ya un desplazamiento de once millones de refugiados. No hay datos sobre el lugar definitivo al que se dirigen los ciudadanos sirios, pero sus primeros pasos se encaminan hacia países como Turquía, Grecia, Macedonia, Serbia, Croacia, Hungría, Austria, Eslovenia e Italia. Estos no son sus destinos finales, son solo el comienzo del camino, ya que muchos de ellos aspiran a países con un alto poder económico porque creen que eso les garantiza un trabajo, tales como Alemania, Francia, Inglaterra y los países nórdicos.

Europa, especialmente Grecia que ya soporta su propia crisis, pero también otros países como Hungría y Eslovaquia en 
situaciones difíciles, y hasta la propia Alemania, donde en ciudades como Heidenau los policías se han tenido que enfrentar a la ultraderecha que no quiere recibir refugiados porque consideran que la inmigración es un claro ejemplo de malestar social. Así pues, Europa no tiene una solución a la crisis migratoria, pero más temprano que tarde tendrá que emplear su influencia para detener las guerras y los conflictos que son el origen de estas avalanchas migratorias. Así se constata las solicitudes de asilo en países europeos entre 1985 y 2015, en el Gráfico 1, como los grandes picos se producen justo en momentos de conflictos.

Gráfico 1.

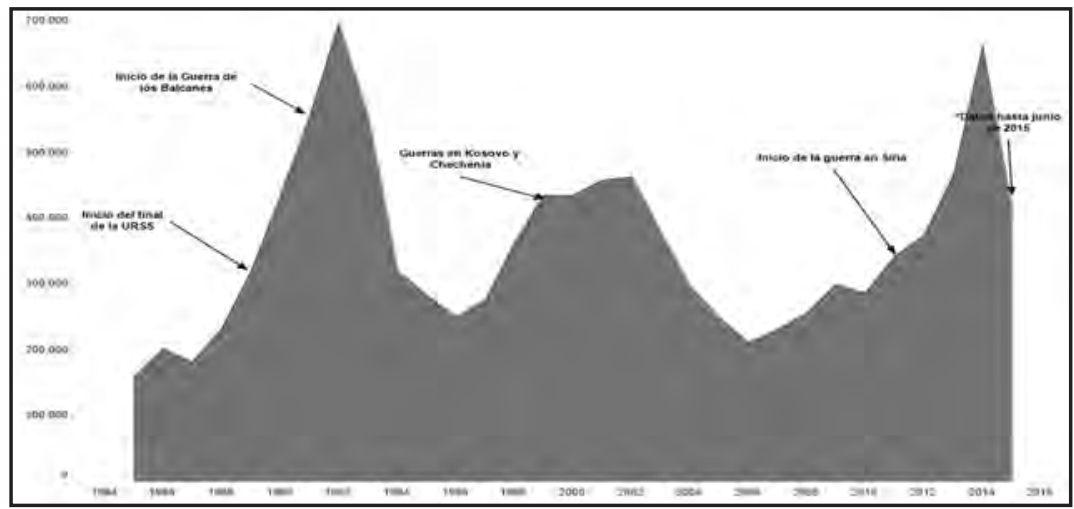

Fuente: Eldiario.es y Eurostat

¿Qué está pasando en otras partes del mundo que ahora afectan a Europa?

Todos los conflictos bélicos terminan con una gran número de desplazados y/o refugiados. Normalmente los que pierden el conflicto. Este fenómeno se ha ido incrementando en los últimos años, no porque haya más guerras, sino porque familiares y amigos que salieron antes del conflicto, ahora llaman a sus familias para la reunificación. En este sentido, ACNUR denunciaba en 2013 que el incremento sería cada día mayor en cuanto a desplazamientos forzosos de personas. En ese año se produjeron 51,2 millones 
de personas a nivel mundial. Un año después la cifra subió a 59,5 millones de los cuales 14,4 son refugiados.

La situación para algunos países que acogen desplazados, la mayoría son refugiados de guerra, es insostenible, ya que supone un esfuerzo considerable atender cada día a millones de personas sin ningún tipo de ayuda de otros países. En este ranking, Turquía es en la actualidad quien más refugiados acoge: 1,59 millones, seguida de Pakistán: 1,51 millones, Líbano: 1,15 millones, República Islámica de Irán: 982 000, Etiopía: 659500 y Jordania: 654000 refugiados. Por el contrario, la procedencia de esos refugiados se centra en tres países fundamentalmente: Siria con 3,88 millones, Afganistán con 2,59 millones y Somalia, con 1,11 millones.

Para Alonso (2015), Jefa de la Oficina de la Unión Europea de Oxfam, el problema es una crisis global de la migración mal dirigida:

La Unión Europea tiene que garantizar la seguridad de las personas que han huido de los conflictos y la inestabilidad política para buscar refugio en Europa. Toda persona tiene derecho a la protección y a la seguridad y bajo el derecho internacional también estamos comprometidos a proporcionar seguridad a los refugiados. Darles la oportunidad de reconstruir sus vidas es nuestra manera de hacer una gran diferencia (Alonso, 2015).

Así, mientras la Organización Internacional para las Migraciones (OIM) trabaja activamente para dar salida a la avalancha de refugiados sirios y resolver sus necesidades, la estrategia de ISIS pasa por hacer entender a los europeos que no son víctimas, sino amenazas con el fin de que les cierren las puertas y se tengan que quedar en su país de origen. Este mismo organismo, señalaba el 17 de febrero de 2016 que 84000 refugiados habían entrado en Europa en lo que va de año por Grecia e Italia, 410 de ellos habrían muerto en el mar. 
La lectura de las imágenes fotográficas...

EL TRATAMIENTO GRÁFICO EN LOS CONFLICTOS: REPERCUSIÓN DE LAS IMÁGENES

Todo conflicto armado supone un cambio social importante. Las guerras pocas veces clarifican una sociedad. Si antes del enfrentamiento ya estaba dividida, tras él, las cosas van a peor porque una guerra supone la división, la separación física y hasta el alejamiento de una parte importante de las mismas, rompiendo familias, comunidades y estados. Los hombres que crean fronteras ven luego como se rompen, se desplazan, se hacen nuevos límites para después reconquistarlos.

Los periodistas, acompañados de algún reportero gráfico o fotógrafo de guerra, han estado siempre en los principales conflictos. Los medios de comunicación han interpretado que un conflicto es un tema de interés y por eso deciden cubrir cada guerra para que sus lectores estén plenamente informados. Y más cuando los medios impresos eran los principales y casi únicos referentes informativos en los conflictos. Ahí quedó para la historia la famosa frase de aquel telegrama que le envía a su corresponsal en Cuba William Randolph Hearst: Quédese. Ústed ponga las ilustraciones, que yo pondré la guerra, en la que el famoso editor animaba a las fuerzas armadas de su país a enfrentarse a España en la Guerra de Cuba de 1898.

Las guerras mundiales también han sido importantes lugares de actividad informativa. De la primera quedan excelentes reportajes gráficos. De la segunda también, aunque aquí la radio se convirtió en la protagonista. Y en sucesivos conflictos, como en Vietnam donde la televisión inició una manera de contar historias en directo y las más recientes en los años 80 del siglo pasado como Afganistán, luego Irak, pasando por los Balcanes en el corazón de Europa, algunos conflictos en África y la más reciente de Siria. En todas las guerras se retrata (en el sentido amplio de la imagen) una realidad que no siempre se puede decir con palabras.

De muchos de los conflictos del siglo xx y de los actuales hay abundantes fotografías que enseñan momentos difíciles de creer, situaciones de desesperación en las personas, miradas frente a 
edificios que se han destruido (Fotos 1 y 2 con tan solo dos años de diferencia), huidas hacia la tierra de nadie, sollozos, lágrimas, muerte y destrucción. El ser humano tiene una capacidad limitada para el dolor, pero lo que la imagen esconde, lo que la fotografía muestra supera con creces lo que como personas somos capaces de entender.

Foto 1. Plaza Saadallab al-Jabri, Alepo, 25 de septtiembre de 2010

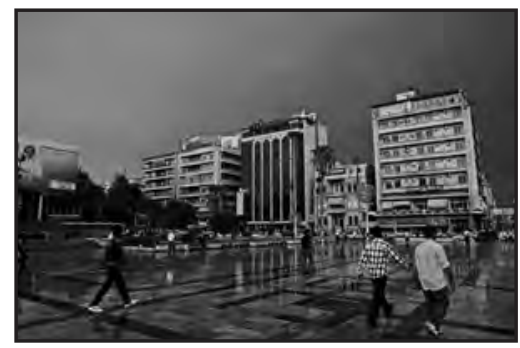

Fuente: Difundir.org

Foto 2. Plaza Saadallah al-Jabri, Alepo, 3 de octubre de 2012

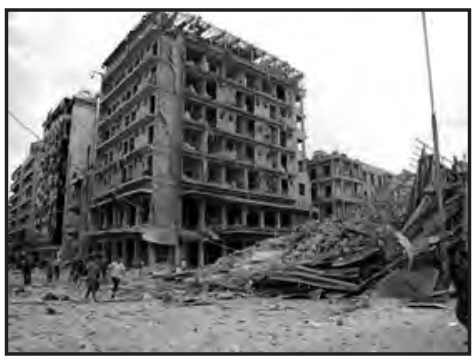

Fuente: Difundir.org

En la retina de muchos ciudadanos que vivieron las guerras del siglo $\mathrm{XX}$ quedan fotografías que recogen sentimientos encontrados. De ellas, la explosión de la bomba atómica, creciendo como un hongo, sobre las ciudades de Hirosima y Nagasaki es un claro ejemplo de cómo los recuerdos han de permanecer para que no se repitan esas situaciones. En el otro lado, el beso de un marineen la ciudad de Nueva York nos recuerda el final del conflicto. 
Un breve recorrido por los últimos enfrentamientos y las imágenes representativas de los mismos, pueden ayudar a entender lo que aportan las fotografías durante y años después de los conflictos bélicos. En la mayor parte de las ocasiones, son personas las que dan ese testimonio de la guerra, es decir su rostro refleja el horror, la tragedia, el sinsentido y todos los adjetivos que se puedan añadir. Algunas, que luego sobrevivieron, se vieron atrapadas en aquel encuadre y tuvieron que vivir a su pesar el resto de sus días con aquel recuerdo. Pero también esa situación de angustia, de desesperación, de tristeza, de trabajo maldito le acompaña al fotógrafo, que en muchas ocasiones no sabe la repercusión que luego tendrá esa imagen. A continuación, tres ejemplos:

La primera de ellas (Foto 3) se tomó en la Guerra de Vietnam y fue portada en todos los periódicos del mundo. La foto se hizo el 8 de junio de 1972 y fue obra de Nick Ut. En la imagen se aprecian niños corriendo, algunos desnudos, sufriendo las consecuencias de una población civil indefensa que es la que más sufre en las guerras. Incluso el presidente norteamericano, Richard Nixon negó que la foto fuera real, pero poco tiempo después las tropas de ese país se retiraron y se acabó la guerra. Esa foto, como otras muchas de conflictos, terminó ganando el Pulitzer.

Foto 3.

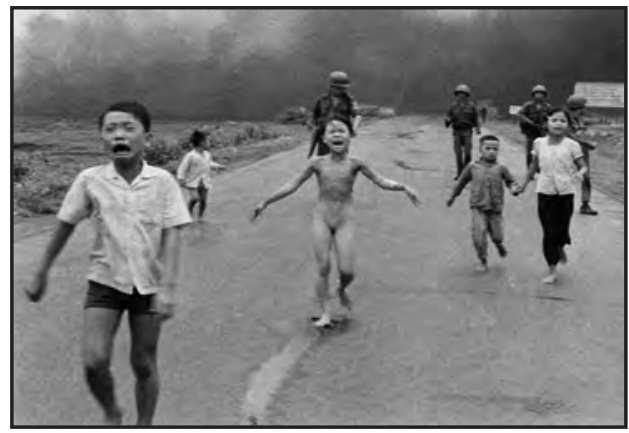

Fotógrafo: NickUt 
43 años después de tomar esa foto, protagonista y fotógrafo se reunieron en Madrid. Nick Ut contó algunas experiencias previas a tomar esa foto. Personas muertas que encontraba por el camino, pero supo al revelar el carrete número siete que una foto podía parar una guerra:

Recuerdo que llegué a Hanoi y me puse a revelar aquellos carretes como un loco [...] Allí estaba la foto: el negativo número siete. Era el número de mi hermano muerto en la guerra, fotógrafo como yo, el séptimo de la familia. Y era una señal. El me dijo antes de morir: "Quiero que hagas la foto que detenga esta matanza." Al ver ese negativo, con Kim Phuc huyendo de las bombas, supe que había hecho la fotografía que pondría fin a la guerra de Vietnam (Rojas, 2015).

La segunda imagen dio la vuelta al mundo cuando Kevin Carter, un reportero gráfico sudafricano y fotógrafo de guerra, ganó un Pulitzer en 1994. No es una imagen de guerra, es una fotografía que plantea las consecuencias de un conflicto, en este caso la segunda guerra civil sudanesa de 1955 a 1972. La destrucción, la pobreza y la hambruna fueron los causantes de aquella situación que captó la cámara de Carter. Esta imagen de un niño sudanés muy delgado y amenazado por un Buitre fue publicada el 26 de marzo de 1993 por The New York Times. La foto trajo consigo un gran revuelo, ya que la opinión pública pidió explicaciones al fotógrafo de por qué no ayudó al niño. Éste alegó que su tribu estaba a menos de 20 metros de donde tomó la foto. Después de unos meses y de caóticas experiencias, el 27 de julio de 1994 se suicidó tras sumergirse en el río donde jugaba de pequeño (Foto 4). 
Foto 4 .

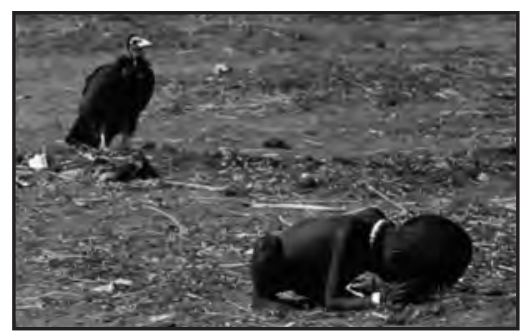

Fotógrafo: Kevin Carter

A veces, las fotografías evitan guerras. En el imaginario del siglo XX hay muchas fotos, sobre todo de la Segunda Guerra Mundial en la que se ven personas en, sobre, al lado o frente a tanques. El tercer ejemplo, más reciente en el tiempo, nos muestra una fotografía que dio la vuelta al mundo. En China, en la Plaza de Tiananmen, un grupo de estudiantes resiste frente al Gobierno al que considera un opresor. El gobierno chino decide desalojar la plaza y cuando todos se van un ciudadano se enfrenta a los tanques y se queda parado, por eso la instantánea se denomina $E l$ hombre del Tanque o el Rebelde Desconocido (Foto 5). La fotografía se toma el 5 de junio 1989, desde un balcón del Hotel Beijing a doscientos metros del lugar. Tres autores de una misma imagen, Jeff Widener de Associated Press (AP), Charlie Cole, de Newsweek y Stuart Franklin de Magnum. No se sabe a ciencia cierta que pasó con aquel ciudadano chino, pero muchos creen que se lo llevó la policía secreta y lo ejecutó.

Foto 5 .

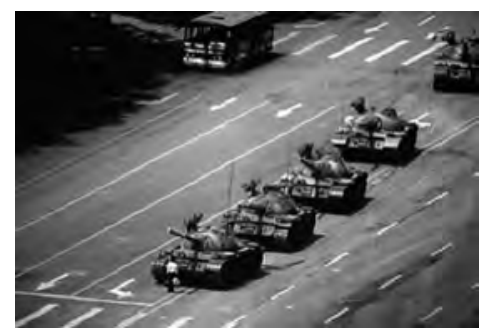

Fotógrafo: Jeff Widener, Associated Press (AP) 
Muchos fotógrafos han pasado por situaciones extremas en conflictos, antes de que se inicien y hasta después. Experiencias personales muy difíciles de superar, pero son denuncias ante la sociedad que defiende y/o ampara las guerras creyendo que se hacen para que el mundo sea mejor y más seguro. Pero ninguna guerra se puede justificar, son éticamente injustificables.

\section{LA GRAN INVASIÓN DE EuROPA RESUMIdA EN LA FOTO DE Aylan Kurdi}

Algunos de los conflictos armados actuales, como el que está sufriendo la población siria, ha llevado a la población a salir del país y quedarse en campamentos de refugiados en los países limítrofes, por si la guerra se acaba y pueden volver. Otros, tras el Efecto llamada de amigos y familiares, han cruzado el Mediterráneo para entrar por Italia o el Egeo para hacerlo por Grecia. Aunque Turquía es el gran país desde donde dan el salto a Europa.

De este conflicto se han publicado muchas fotos, (véase Fotos 1 y 2). Las fotografías demuestran que Siria es un país tomado por al menos dos grandes facciones que han roto el país por la mitad. De un lado y de otro, la propaganda de los que mantienen la guerra, se ha registrado bajo las fotos de algunos reporteros de guerra. Cuando el conflicto empeora y los periodistas son secuestrados y ejecutados, el volumen de imágenes desciende y la información sobre la guerra se hace más escasa.

En el caso de Europa, el problema de la guerra se traslada a su territorio cuando se ven invadidos por miles de ciudadanos, la mayoría refugiados sirios. La fotografía que debería parar esta guerra se produjo el día que Aylan Kurdi perdió su vida intentado huir de la guerra con su padre y buscar una vida mejor. Fue un miércoles 2 de septiembre de 2015 cuando su cuerpo apareció ahogado en una playa turística Bodrum en Turquía (Fotos 6 y 7). 
Foto 6 .

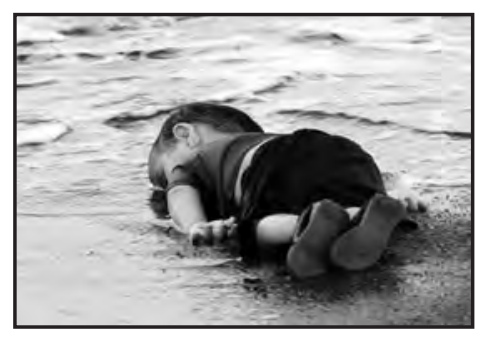

Foto 7 .

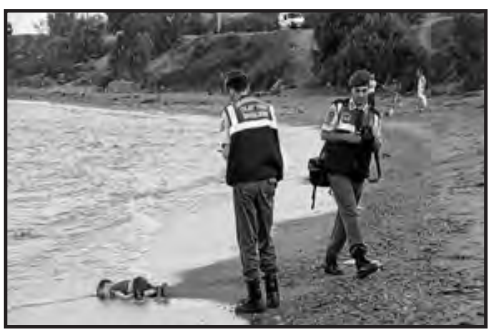

Fotógrafo: Nilüfer Demir

Esa imagen logró remover y despertar las conciencias de Europa y la sociedad (¿civilizada?) ante una guerra que obliga a sus ciudadanos a desplazarse a lugares sin conflictos. Y ya se ha convertido en un icono visual de este siglo. Una vez más, una tragedia da origen a una fotografía para la historia. Pero ese día murieron tres niños más en las dos embarcaciones que con 18 inmigrantes se dirigían a la isla griega de Kos.

La imagen es obra de la fotógrafa de Reuters, Nilüfer Demir. Junto al niño ahogado tomó otras fotos de los guardias costeros turcos recogiendo el cadáver de Aylan. Ese niño que todos vimos en la fotografía dejó de ser anónimo y pasó a llamarse Aylan Kurdi, tenía tres años y murió junto a su hermano de cinco, Galip y también su madre. En declaraciones a los medios de comunicación, la autora que trabaja para la agencia de noticias turca Dogan, espera que la imagen sirva para parar este conflicto, que ya supera cualquier adjetivo: “[...] Cuando me di cuenta de que no había nada que hacer para devolverle la vida a aquel niño, pensé que tenía que tomar la foto para mostrar la tragedia" (Reuters 2015). Aylan y su familia ya no llegaron a Canadá, donde les esperaba otros familiares.

Esta sobrecogedora imagen que heló las conciencias del mundo es una de las 3000 muertes que se calculan en los últimos años de los refugiados que tratan de alcanzar Europa, entre ellas un número muy alto de niños. Pasados ya cinco meses de aquella imagen, hubo cierto entendimiento en las potencias, pero la guerra continúa y la fotografía que removió conciencias sigue 
esperando que el fin de la guerra llegue pronto para que como ciudadanos puedan vivir en paz en la tierra de sus raíces y no tener que convertirse en refugiados en otros países, donde la situación económica no es tan ideal como ellos piensan.

¿QUÉ HAN DE HACER LOS MEDIOS DE COMUNICACIÓN CON ESTE TIPO DE IMÁGENES? CONSIDERACIONES ÉTICAS

Se ha dicho siempre que sin los medios de comunicación no existiría la democracia. Ellos son los que denuncian los abusos del poder, quienes se enfrentan a gobernantes, aunque a veces los censuren, los que construyen una sociedad civil más consolidada, los que se esfuerzan para que la convivencia sea cada vez mejor, pero no tienen la solución a todos los conflictos.

En el caso de la fotografía, como se ha constatado en los apartados anteriores, los reporteros de guerra muestran los resultados de los conflictos. No manipulan, ni tergiversan, ni toman unas fotos sí y otras no. Su trabajo consiste en abrir el ojo de su cámara para que otros puedan entender la realidad de un conflicto. Las preguntas serían: ¿Qué han de hacer los medios de comunicación cuando reciben determinadas imágenes de guerra? ¿Hay un límite para publicarlas? ¿Cuáles son las razones éticas para hacerlo/no hacerlo? Sigamos con el ejemplo de Aylan Kurdi, donde la unanimidad quedó patente en los medios escritos (también en los audiovisuales que reprodujeron la foto), ya que al día siguiente el 99\% de todos los periódicos del mundo pusieron en su portada esa imagen. Cabría pensar entonces que si cada día se coloca en portada una fotografía con la desesperación de las personas que huyen de la guerra, ese conflicto desaparecería.

Es un debate ético que no tiene una solución fácil. Ese día y los siguientes, los medios se implicaron en explicar la imagen y otras imágenes de guerra que se recogen en este texto. En varias secciones de los principales periódicos se pidieron explicaciones a expertos en fotografía y a analistas políticos de si la imagen serviría como en otras ocasiones para frenar la guerra, pero aún se espera 
la respuesta. Sin embargo, otros temas de interés desplazan de la portada los conflictos bélicos y los medios reflejan la realidad informativa de cada día; por este motivo, pasados unos días ya los medios dejan de poner fotos sobre el conflicto, sobre los refugiados hacia Europa y sobre la guerra. Pero esto no se termina, y aún habrá más fotos de portada cuando algún fotógrafo de guerra, o alguien, se encuentre inesperadamente en una playa con cientos de personas muertas.

La mayoría de los grandes periódicos y revistas del mundo tienen claro que si una foto de guerra es informativa debe publicarse. Entre otras razones envían al frente de batalla a un fotógrafo del medio. En ocasiones, hay limitaciones a la hora de colocar una foto en portada. A veces, mostrar la crueldad no es la mejor manera de acabar con ella, por eso los editores gráficos en los medios han de hacer un trabajo selectivo que ayude a la sociedad a entender un conflicto, no a alargarlo.

Las cuestiones éticas sirven como baremo para buscar el equilibrio. Los medios no han de esconder, ni ocultar las fotografías por muy duras que sean, pero tampoco han de publicarlas por el simple hecho de que tienen la imagen. Si una fotografía sirve para denunciar una situación, para demostrar que un gobierno está maltratando a sus ciudadanos, para anunciar que un problema político generará en el futuro terribles consecuencias, si también descubre una fotografía el cadáver de un niño, como símbolo de la barbarie de una sociedad llamada civilizada, entonces no cabe la ética, es preciso ser responsables, afrontar el reto y publicar las imágenes que denuncien esos hechos y otros que se lleguen a cometer. Los periódicos y revistas no publicaron la foto de Aylan para vender más. Lo hicieron porque esa era la noticia que agitaría las conciencias de los ciudadanos, también las de sus gobernantes, como lo fueron otras que figuran en este texto.

Por último, los limites para publicar o no deben ponerlos los autores de la foto, pero sobre todo los editores gráficos que deciden qué foto/s irán acompañando un texto informativo. Fuera de los medios sensacionalistas, el resto de las fotos se ajusta a un estricto sentido informativo. No se busca el sensacionalismo, sino 
la realidad informativa. Y frente a situaciones dolorosas, tristes, asesinatos, atentados, etc., caben interpretaciones varias, pero en una hay unanimidad: el derecho a la información está por encima de todas. Y la foto que sea informativa no se debe desechar. En los medios de comunicación también surgen las dudas y las tuvieron con la foto de Aylan (Reuters, 2015):

Cuando Reuters la envió a sus clientes al mediodía del 2 de septiembre causó ya una conmoción en las redacciones y un debate acalorado: ¿Había que publicarla? Por supuesto. Hay algo disfuncional en ella y eso la hace aterradora. Ves la orilla del mar, donde juegan los niños en la arena. Y en el centro de la imagen Aylan Kurdi, sirio y blanco como nosotros, vestido de primer mundo, como un muñeco varado. $Y$ sabemos que no es un muñeco porque un policía se acerca a rescatar su cuerpo inerte. Tan sencilla y tan macabra. Es la foto del año, de la década y una de las grandes de la historia.

Por último, ha levantado cierta polémica el hecho de que Nilüfer Demir no se hubiera presentado al premio más prestigioso de fotografía, que seguro hubiera ganado: World Press Foto. Sus razones tendrá. Pero lo que importa es que esta fotografía denunció una consecuencia de la guerra y al ser tan impactante, todos los periódicos reflejaron en su portada aquel niño ahogado en una playa.

\section{ConClusiones}

Para desgracia del ser humano, los conflictos bélicos que ocasionan millones de refugiados y desplazados en el mundo, ofrecen realidades tan terribles que si no hubieran sido fotografiadas no se podrían creer. La historia del siglo XX y sus guerras son ahora vistas con perspectiva en el recuerdo de las fotografías que entonces 
se hicieron, como lo será la foto de Aylan Kurdi dentro de 50 o 100 años cuando se hable de emigración, guerras, conflictos, etc.

El imaginario del siglo XX suma importantes fotografía que en su día sirvieron para tomar conciencia a los políticos implicados en la guerra, como Richard Nixon, pero otras imágenes que claramente suponían denuncias a algunos regímenes políticos no surtieron tanto efecto. Lo hicieron años después cuando el dictador murió o fue derrocado, las fotografías de los muertos que dejaban atrás fue el motivo para entender que años antes ya otra fotografía había denunciando esa situación.

Los medios de comunicación, periódicos y revistas, reciben cada día miles de fotografías, bien de producción propia que mandan sus fotógrafos, bien de agencias con las que tienen un acuerdo. La tarea de selección por parte de los editores gráficos no es sencilla. Hay que valorar muchos aspectos de la fotografía. Lo que dice, lo que no dice, lo que creemos que puede/no puede trasmitir, de lo que informa, de lo que calla, etc. Pero, en ningún caso, se deben guardar imágenes como la de Aylan Kurdi porque son como muchos creen aquel tipo de fotografías que servirán para parar una guerra.

La ética no está reñida con la información. Son complementarias. Sirven al mismo objetivo: informar con rigor al ciudadano. Los fotógrafos de guerra ofrecen situaciones reales, muchas veces tomadas de manera rápida para evitar ser disparados. Otras ya muestran la destrucción y los resultados de la batalla. Se toman después de que pasan las tropas. En ambos casos, el fotógrafo no miente. Solo muestra a través de su lente lo que cree que otros desean ver. Entonces, esa fotografía es la que al día siguiente o dentro de unas horas estará publicada en un medio digital. Cada vez es más difícil el trabajo de los fotógrafos/ reporteros de guerra. Se exponen más en los conflictos y necesitan tomar una distancia entre guerra y guerra, pero sin ellos, no se entenderá la información que reciben cada día los periódicos. Pueden leerse muchas informaciones sobre los refugiados y la guerra de Siria, pero solo cuando se hace pausa ante una fotografía como la de Aylan Kurdi, se sabe el valor que tiene la imagen. 


\section{BiBliografía}

Alonso, N. (2015). "Un millón de refugiados y migrantes han huido a Europa este 2015". Oxfam Intermon 23/12/2015. Disponible en: <http://www. oxfamintermon.org/es/sala-de-prensa/nota-de-prensa/ un-millon-de-refugiados-migrantes-han-huido-europaen-2015> [Fecha de consulta: 24 de febrero de 2016]

Andrés, S. de; E. Nos Aldas, A. García Matilla. (2016). "La imagen transformadora. El poder de cambio social de una fotografía: la muerte de Aylan”. COMUNICAR, 47(2).

Reporteros sin Fronteras. Barómetro de la Libertad de prensa. Calcula el número de periodistas y colaboradores muertos. Disponible en: <https://rsf.org/es/ barometro $>$ [Fecha de consulta: 25 de febrero de 2016].

Reuters. (2015) "La autora de la foto del niño muerto en la playa turca espera que la imagen lleve a "una solución”". En: El Periódico. 3 de septiembre de 2015. Disponible en: <http://www.elperiodico.com/es/noticias/ internacional/autora-foto-del-nino-muerto-una-playaturca-espera-que-imagen-ayude-una-solucion-4479023> [Fecha de consulta: 24 de febrero de 2016]

Rojas, A. (2015). "El selfie de la niña napalm". En: $E l$ Mundo. 16 de octubre de 2015. Disponible en: $<$ http://www.elmundo.es/internacional/2015/10/16/ 561fede322601da2798b4614.html $>$ [Fecha de consulta: 23 de febrero 2016]

(2015). "La verdadera foto del año". En: El Mundo. 18 de febrero de 2016. Disponible en: <http:// www.elmundo.es/television/2016/02/18/56c5af98e2704e e1388b4588.html> [Fecha de consulta: 23 de febrero de 2016] 
Salvo, P. Di. (2015). "The 19 Million Project: Bypassing National Borders and Narratives to Tell The Stories of Refugees". En: Journalism.co.uk 19 de noviembre. Disponible en: <https://www.journalism.co.uk/news/ the-migration-crisis-how-the-19-million-project-aimsto-bypass-borders-and-narratives-/s2/a584989/>

Sánchez, R. "Cómo se distribuyen los refugiados por Europa en la peor crisis desde la II Guerra Mundial". El Diario. Disponible en: <http://www.eldiario.es/ desalambre/MAPA-peor-crisis-refugiados-anos_0_ 425207787.html> [Fecha de consulta: 9 de diciembre de 2015] 


\title{
La ética en las instituciones de la memoria sonora
}

\author{
Perla Olivia Rodríguez Reséndiz \\ Instituto de Investigaciones Bibliotecológicas y de la Información, \\ Universidad Nacional Autónoma de México, México
}

$\mathrm{L}$

a reflexión en relación con el Uso ético de la Información, se sitúa en un contexto caracterizado por la tensión permanente entre la información y las esferas del poder. El poder y el conocimiento han estado vinculados históricamente. El conocimiento ha permitido mantener el poder y éste a su vez ha establecido los mecanismos para monopolizarlo, es decir, concentrar el saber en unas cuantas personas; excluyendo con ello a la mayoría de los ciudadanos.

Durante el periodo en que la Iglesia detentó el conocimiento, desde los periodos clásicos hasta la Edad Media, basó su poder en una red de símbolos y medios de orientación que le daban significado. El poder de la Iglesia fue desplazado por el surgimiento del Estado y por el desarrollo del conocimiento científico (Elias, 1994).

Con la incorporación de las tecnologías de información y comunicación, se ha incrementado la velocidad y se ha ensanchado el acceso a la información que se resguarda en las instituciones de la memoria. La información es un medio para producir conocimiento y es un instrumento de poder que, ahora más que nunca, está en estrecha relación con el desarrollo tecnológico. En los albores de la revolución biológica, la información es el principal insumo para creación de servicios y productos que son la base de la economía internacional. Lo que significa que si durante la Revolución Industrial, la fuerza de trabajo fue la materia prima, en la actualidad, el trabajo intelectual es el eje de la producción y las 
tecnologías de información y comunicación son las herramientas (Castells, 2004).

Por ello, uno de los rasgos característicos de la sociedad contemporánea es el uso de información y conocimiento, para generar nuevo conocimiento y dispositivos de procesamiento y comunicación de la información, en un circuito continuo de innovación y usos de la innovación (Castells, 2004). En este circuito la relación entre la sociedad, la información y la tecnología está mediada por el Estado, que puede ser la fuerza innovadora y motivadora de la innovación tecnológica o bien el contenedor, paralizador e incluso censor de la creación y aplicación de la tecnología. La información que resguardan las instituciones de la memoria, no escapa del deseo de control del Estado, ocupa un lugar relevante en este circuito, porque es en éstas instituciones donde se preserva el saber que ha sido producido por siglos, y la información actual que es el resultado de la creación científica, periodística, cultural y artística, entre otras. Este circuito es el fundamento del ecosistema digital contemporáneo y por ello, las instituciones de la memoria están en constante relación con el poder.

Nunca antes, las instituciones de la memoria sonora: fonotecas, archivos sonoros, archivos de investigación, fonotecas de radio, entre otras, habían tenido ante sí el desafío de resguardar esa cantidad de documentos sonoros y, tampoco habían advertido tal tensión con el poder. Esta tensión surge de que los archivos sonoros resguardan la información que da cuenta de la historia contemporánea, a través de las voces de los grandes pensadores, de la expresión artística, de los sucesos históricos que han transformado el rostro de las sociedades, de las decisiones de Estado que han afectado la vida de millones de personas y de las declaraciones que dan cuenta del pensamiento de nuestros gobernantes.

En los archivos se pueden conservar tanto discursos elocuentes que enaltecen a la sociedad, así como desafortunadas declaraciones que dan cuenta de la falta de conocimiento y compromiso social. Las instituciones de la memoria sonora son 
responsables de mantener la autenticidad y la integridad (Edmondson, 2008) de todo tipo de documentos. Deben proteger los documentos del deterioro, de los daños ocasionados por las inadecuadas condiciones de conservación, de la alteración deliberada y de la censura.

A lo largo de la historia de los archivos sonoros hemos sabido de arriesgadas acciones de salvaguarda, como las que se realizaron para resguardar las colecciones de cilindros de cera de la $\mathrm{Pho}$ nogrammarchiv de Berlín durante la Primera Guerra Mundial; las actividades destinadas a proteger de la destrucción importantes grabaciones sonoras durante la dictadura militar de Pinochet; el resguardo de las colecciones sonoras que dan cuenta de la violencia y los procesos armados en Guatemala durante más de tres décadas, entre otros. Estas acciones de salvaguarda basadas en la intuición y en el deseo de proteger el legado sonoro, expresan claramente el deber ser de un archivo sonoro: Proteger la memoria documental de la humanidad para que pueda ser conocida por las generaciones actuales y del porvenir.

Aún cuando parece que la salvaguarda de la herencia documental sonora es un mandato vetusto, lo cierto que es que los valores y principios éticos sobre los cuales se basa la operación y gestión de un archivo son recientes, se han establecido hace poco (Ullate i Estanyol, 2016), y en esta labor han sido notables las aportaciones del Dr. Edmondson y las discusiones que se han generado en el seno de las principales agrupaciones de archivistas como la Asociación Internacional de Archivos Sonoros y Audiovisuales (IASA), la Federación Internacional de Archivos de Televisión (FIAT), la Federación de Archivos Fílmicos (FIAF), entre otras.

Como resultado de este esfuerzo, hace casi dos décadas, se publicó el TC-O3 La salvaguarda del patrimonio sonoro: ética, principios y estrategias de preservación de la IASA (1997) documento que definió las tareas documentales que se deben llevar a cabo en un archivo sonoro, los principales problemas a que se enfrenta el archivo y cuáles deben ser los lineamientos básicos a seguir frente la inminente digitalización de las colecciones sonoras. Así ante la falta de documentos que orientaran el quehacer del 
archivista sonoro, ésta publicación cobró relevancia y ha sido utilizada como un documento recurrente de consulta entre el gremio de archivistas sonoros. Incluso conviene señalar que el TC-03, como es conocido entre los archivistas, fue reeditado en 2001, 2003 y 2005 (Ullate i Estanyol, 2016).

Años después, la IASA consideró que la ética debe cimentarse en los roles que participan en las tareas de preservación. Es decir, en todas las personas que intervienen en los procesos documentales. Desde la persona que produce un documento, quien lo deposita, el archivista, el técnico y el usuario. Bajo esta perspectiva, todos los actores involucrados en la preservación tienen una responsabilidad ética.

El creador o autor de un documento sonoro es la persona o bien el grupo de personas que participan en una producción sonora. Entre otros, deben citarse a los guionistas, las voces, los productores, asistentes, técnicos, entre otros. El creador de un documento sonoro tiene la responsabilidad de documentar quién o quiénes han intervenido en el proceso de producción. Y el archivo sonoro es responsable de asentar correctamente la información relacionada con el autor o creador de un documento sonoro. Esta información es fundamental para la conservación y acceso a largo plazo de todo documento sonoro.

Los depositantes, pueden las instituciones o bien las personas que resguardan una colección que desean que se incorpore a un archivo. Los archivos deben contar con toda la documentación relativa a la colección que se incorpora al acervo. La IASA (2010) ha establecido que si una colección no cuenta con los derechos de uso claramente establecidos es mejor no incorporarla al archivo. Sin embargo, esta afirmación debe ser cuidadosamente analizada por los archivos nacionales que tienen a su cargo la preservación del patrimonio nacional sonoro de un país.

También el personal técnico involucrado en tareas de limpieza, digitalización y almacenamiento digital tiene responsabilidades éticas. La IASA (2010) reconoce que en los últimos años a partir de las incorporación de Sistemas de Gestión y Almacenamiento Masivo Digital, es decir de plataformas digitales para la preservación 
de los documentos sonoros, se ha demandado la formación de ingenieros especializados en todos los procesos de digitalización, creación de bases de datos, migración e importación de media y metadata, acceso en línea, entre otros procesos de preservación digital de un archivo. El personal técnico es una pieza clave en las tareas de preservación digital, un error humano, por falta de conocimiento o compromiso, puede provocar que se pierdan miles contenidos sonoros.

También, los usuarios deben tener una responsabilidad ética. Su responsabilidad ética debe ser establecida a través de manuales de acceso al acervo y conocida por todas las personas que deseen consultar el archivo. Las políticas de acceso y uso de los documentos sonoros, deberán establecerse con base en la legislación nacional en materia de derechos de autor. (IASA 2010). Dado el incremento del acceso y descarga de contenidos digitales sonoros, es muy importante que los usuarios conozcan las responsabilidades éticas y legales que podrían tener si alteran, modifican o utilizan un contenido sin tomar en cuenta los derechos de uso correspondientes.

De todos los roles, el documentalista o archivista sonoro es el profesional responsable de velar por la salvaguarda de los archivos sonoros. Por lo tanto, su tarea es ininterrumpida y de enorme valía para el archivo sonoro y para la sociedad.

El archivista tiene un vínculo y tensión constante con el poder. No sólo debe mantener la autenticidad y garantizar la integridad de los documentos del archivo, también debe sortear los procesos de selección para el acopio o bien para priorizar la digitalización de colecciones sonoras. Debe tratar de evitar que se releguen o bien se pongan en riesgo manifestaciones sonoras, ideas, noticias e incluso paisajes sonoros que no son considerados valiosos por quienes dirigen el archivo. Para ello, ha de privilegiar el interés público sobre los gustos e intereses de grupo.

Si no fuera suficiente, incluso el profesional debe lidiar también con algunos autores que con el afán de ganar más regalías intentan prolongar a través de una nueva versión digital, el tiempo de vida de un documento para que no sea de dominio público. 
La situación de cada archivo es diferente y depende del contexto social, político y económico. No obstante la elaboración del Código de ética de una institución de la memoria sonora es una tarea ineludible y necesaria. Algunos de los principios ampliamente discutidos y consensuados por el gremio de archivistas sonoros que debe tomar en consideración un Código de ética son:

Preservar y proteger, siempre y ante cualquier circunstancia o contexto social, político y económico, los fondos del archivos sonoro. Todos los procesos documentales se deben desarrollar con probidad y de acuerdo con las recomendaciones internacionales, estándares y con base en la normatividad existente en la materia. El acceso al archivo debe ser incluyente, por lo tanto, se deben atender las peticiones de consulta de todas las personas sin importar su clase social, sexo, edad o discapacidad. El Código de ética también debe señalar que los directivos del archivo sonoro deben evitar los conflictos de interés y el uso inadecuado de los materiales del archivo. A la condición anterior se suma que se deben transparentar a través de la difusión pública todas las actividades, recursos económicos, selecciones curatoriales y otras tomas de decisiones que afecten la preservación de las colecciones sonoras. Otro rasgo a considerar consiste en incentivar y motivar, el crecimiento profesional para todos los documentalistas, archivistas y técnicos. Finalmente, se debe promover la colaboración y ayuda mutua entre los colegas del archivo y entre las instituciones de la memoria sonora.

Además de estos principios, cada archivo puede sumar otros que expresen su misión y vínculo con la sociedad. En la creación y redacción del Código de ética deben participar todos los documentalistas y archivistas de la institución y aunque no contemple todos los posibles casos que se presentan en un archivo, sí debe orientar la conducta a seguir.

Conviene señalar que existen situaciones como por ejemplo, el cese o disminución de los fondos públicos para continuar los trabajos de un archivo que pueden paralizar y condicionar las tareas de una institución. En fechas recientes se publicó que el financiamiento público de los archivos audiovisuales de Timor Oriental se ha detenido, lo que pone en riesgo la supervivencia de los 
archivos de resistencia y de la masacre de Santa Cruz en 1991 (Stahl, 2016). Esta es probablemente la situación más difícil que enfrentan los archivos. Por ello, es deseable que las instituciones de la memoria sonora ganen autonomía para que el financiamiento, las designaciones de los jefes del archivo, los materiales que se van a conservar y la vida misma del archivo no estén supeditadas a los gobiernos en turno y a los intereses políticos que los condicionan.

La existencia del pasado depende de las acciones del presente. La información sonora, la que escuchamos día a día, forma parte de nuestra herencia documental. Por lo tanto, la conservación, selección y acceso de los contenidos sonoros ha de corresponder al interés público y no a intereses de particulares o de grupo.

El mayor desafío ético de las instituciones de la memoria sonora se ubica en su relación con el poder. La actividad archivística es eminentemente política. Está basada en una serie de valores y puntos de vista (Edmondson, 2016) que determinan la ética a partir de la cual se preservarán los sonidos del porvenir.

\section{BibliografÍA}

Castells, M. (2004). La era de la información: economía, sociedad y cultura. Vol. 3. Siglo XXI.

Edmondson, R. (2008). Filosofía y Principios de los Archivos Audiovisuales. 2da. edición. UNESCO.

-_—. (2016). Audiovisual Archiving: Philosophy and Principles. 3ra. edición. UNESCO.

Elías, N. (1994). Conocimiento y poder. Madrid: La piqueta. 
International Association of Sound and Audiovisual Archives (IASA) (1997). The Safeguarding of the Audio Heritage: Ethics, Principles and Preservation Strategy. IASA.

-_—. (2010). Ethical Principles for Sound and Audiovisual Archives. IASA.

Ullate i Estanyol, M. (2016). "Ética y Archivos sonoros: el camino se hace al andar". Clip. Boletín de SEDIC. Disponible en: <http://clip.sedic.es/article/etica-archivossonoros-camino-se-al-andar/> [Fecha de consulta: 27 de junio de 2016].

Stahl, M. (2016). "Max Stahl Archive in Peril?" En: Timor Archives. Disponible en: <timorarchives.wordpress. com/2016/04/13/max-stahl-archive-in-peril/> [Fecha de consulta: 27 de junio de 2016]. 


\title{
Aspectos éticos del Acceso Abierto
}

\author{
Filiberto Felipe Martínez Arellano \\ Instituto de Investigaciones Bibliotecológicas y de la Información, \\ Universidad Nacional Autónoma de México, México
}

\section{INTRODUCCIÓN}

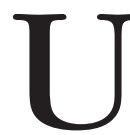

na de las tendencias actuales dentro de la comunicación científica, particularmente en las Humanidades y Ciencias Sociales, es el Acceso Abierto (AA), el cual implica el acceso, sin costo ni restricciones, a las publicaciones que incluyen los resultados de proyectos y actividades de investigación, en especial aquellos financiados con fondos públicos. Dentro del movimiento del Acceso Abierto se encuentran involucrados tres actores principales, quienes juegan un papel preponderante dentro de éste, los académicos que generan la materia prima o contenido de las publicaciones, los editores quienes son los encargados de materializar las publicaciones y los bibliotecarios, como encargados de facilitar el acceso a estas publicaciones. Dentro del papel que desempeñan cada uno de estos actores, se pueden encontrar una serie de aspectos relacionados con una conducta ética, entendida como el conjunto de obligaciones de los individuos y las organizaciones, basadas en las normas y valores morales establecidos en una sociedad o comunidad, que indican lo que es bueno y malo, correcto e incorrecto, que orientan el comportamiento y acciones de una persona o grupo, y que ayudan a los individuos y a las 
organizaciones a elegir entre varios cursos alternativos de acción (Díaz Vargas et al., 2009). Teniendo como marco de referencia este contexto, el presente documento aborda una serie de aspectos éticos relacionados con los tres actores principales dentro del movimiento del Acceso Abierto.

\section{Acceso Abierto y aspectos éticos}

El Acceso Abierto es un movimiento internacional que surge con la finalidad de promover el libre acceso a la información y a los productos de la investigación científica, particularmente aquellos generados con recursos públicos. La extensamente citada Iniciativa de Budapest para el Acceso Abierto (2002) señala que el acceso abierto a la literatura comprende su disponibilidad gratuita en Internet, permitiendo a cualquier usuario leer, descargar, copiar, distribuir, imprimir, o usarla con cualquier propósito legal, sin ninguna barrera financiera, legal o técnica, fuera de las que implica acceder a Internet. La única limitación en cuanto a su reproducción y distribución y el único rol del copyright, es respetar la integridad de los trabajos y el derecho de los autores a ser adecuadamente reconocidos y citados.

Adicionalmente, Suber (2004) menciona que la literatura en Acceso Abierto (AA) tiene que ser digital, en línea, libre de cargos y de la mayoría de las restricciones sobre derechos de autor y licenciamiento. Lo que lo hace posible es el Internet y el consentimiento del autor o el titular de los derechos de autor.

Sin duda alguna, en las anteriores conceptualizaciones del AA es posible encontrar una serie de características, las que inherentemente poseen connotaciones éticas, aunque en muchas ocasiones, éstas solo han sido mencionadas y discutidas desde una perspectiva pragmática.

Con respecto a lo anterior, Suber (2008) señala que dentro del AA se pueden encontrar una serie de argumentos morales, pragmáticos y epistemológicos, y que éstos no son independientes, sino que se entrelazan. Por ejemplo, los argumentos 
pragmáticos sobre el AA (acelera la investigación) son componentes de argumentos morales (la aceleración de la investigación es buena). Del mismo modo, el argumento epistemológico sobre que el AA facilita la auto-corrección científica, puede convertirse fácilmente en un componente de un argumento moral (lo que posibilita la auto-corrección es bueno). Adicionalmente, menciona algunos ejemplos de los argumentos morales del AA: elimina barreras de acceso innecesarias para los autores y los lectores; devuelve el control de la academia a los académicos; el incremento del impacto de los autores coadyuva a su propósito de escribir artículos de impacto, en lugar de obtener beneficios económicos; contrarresta la creación deliberada de una escasez artificial; contrarresta la mala distribución, deliberada o accidental, del conocimiento; hace accesible un bien común; atiende a las necesidades de los insuficientemente atendidos; y en relación con la investigación financiada con fondos públicos, el AA es una parte fundamental de los derechos y equidad de los contribuyentes.

Por otro lado, Parke (2013) también hace mención a una serie de argumentos éticos relacionados con el AA. El argumento más común para el AA, esgrimido por los científicos y quienes proporcionan fondos para la investigación, es que el intercambio de datos dará lugar a un rápido progreso científico y a una reducción en la duplicación innecesaria de la labor científica. En el contexto de las Humanidades y las Ciencias Sociales, estos argumentos a veces se complementan con aquellos que enfatizan la importancia del papel de comunidades abiertas a la reflexión crítica y a la posibilidad del AA para apoyar la creación de espacios para la crítica constructiva y validación epistemológica, lo que significa que la investigación puede ser más profunda, más rica, más amplia, y en algunos casos, más rápida.

Un segundo argumento a favor del AA, particularmente en el contexto de la investigación financiada con recursos públicos, se basa en las obligaciones de reciprocidad. Se argumenta que los resultados de la investigación financiada por fondos públicos deben ser puestos a disposición de los que han pagado por ello. Este es un aspecto relacionado con la responsabilidad social del 
investigador y de quienes utilizan recursos públicos para contribuir a la difusión del conocimiento.

Asimismo, puntualiza que se ha argumentado que los modelos de publicación basados en la suscripción son injustos, ya que obligan a los académicos, cuyo trabajo es financiado con recursos públicos, a publicar sus trabajos en revistas comerciales, en las cuales ellos participan en la revisión por pares y como miembros de cuerpos editoriales, pero después tienen que pagar para acceder a los frutos de su propio trabajo intelectual. Los editores de revistas académicas se benefician injustamente del trabajo de los investigadores académicos, estableciendo restricciones sobre quién puede acceder al conocimiento y sobre quién ha de ser considerado como un productor de conocimiento.

Finalmente, señala que el sistema actual de publicaciones basado en la suscripción es inherentemente conservativo y da lugar a un estrechamiento de la vida intelectual y académica. Por el contrario, los modelos de la publicación de AA ofrecen la posibilidad de alejarse de un enfoque de las publicaciones impulsadas por los imperativos de la comercialización y de puntos de vista excesivamente rígidos sobre las fronteras disciplinarias y los formatos de publicación.

Figura 1. Vias del acceso abierto.

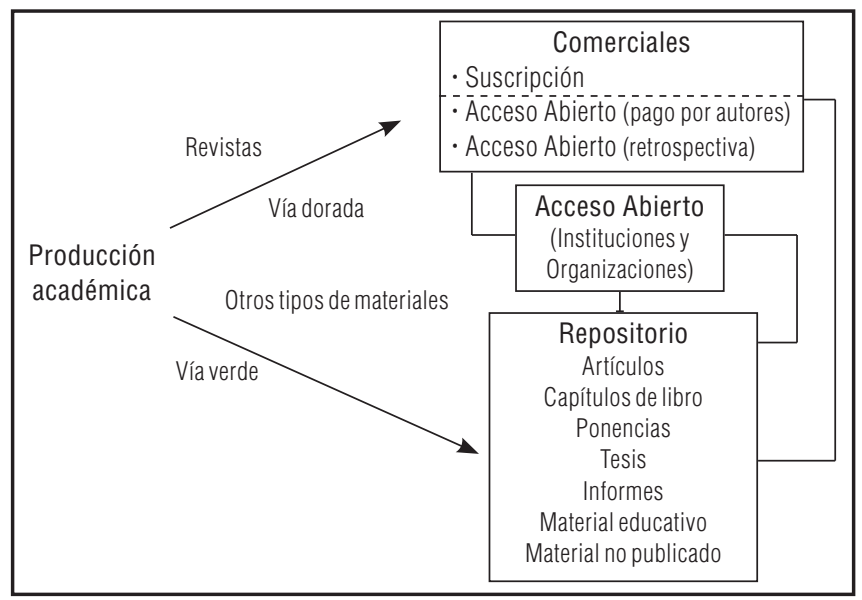

Fuente: Elaboración propia 
Ciertamente, el movimiento del AA promueve el acceso sin restricciones a los productos del trabajo de investigación, siendo los más representativos de éstos los artículos publicados en revistas; sin embargo, el AA se ha extendido a otro tipo de recursos, los cuales también son resultado de las actividades de investigación, tales como libros, capítulos de libros, tesis o ponencias presentadas en eventos académicos. Lo anterior implica que dentro del movimiento del AA existen dos vías para lograr su objetivo, las cuales han sido denominadas como la Vía Dorada y la Vía Verde.

La Vía Dorada se caracteriza por la publicación en revistas, generalmente en formato electrónico, siguiendo los mismos procedimientos y políticas de las revistas impresas, siendo lo más importante la evaluación rigurosa de artículos a través de la revisión por pares o árbitros. Dentro de los diversos tipos de revistas publicadas en AA se encuentran aquellas que son publicadas por instituciones y organizaciones académicas, lo cual es una práctica común en las Humanidades y las Ciencias Sociales, pero además existen otras que cobran una cuota para que los artículos sean publicados en Acceso y se encuentren disponibles para cualquier usuario.

Por otro lado, la segunda alternativa del AA, la Vía Verde, es caracterizada por el archivo o depósito de recursos digitales en repositorios, siendo los más comunes los repositorios institucionales. En éstos, los autores autoarchivan sus productos académicos o existe una infraestructura que apoya el archivo o depósito de ellos. En algunos casos, los números retrospectivos de los revistas por suscripción son puestos en AA, pudiendo estos artículos ser incorporados en los repositorios de su institución. Adicionalmente, los artículos de las revistas en AA, publicadas por instituciones y organizaciones académicas, son incorporados en los repositorios institucionales.

Asimismo, en los repositorios se encuentra una gran diversidad de recursos, tales como artículos, tesis y disertaciones, libros, capítulos y secciones de libros, reportes y documentos de trabajo no publicados, multimedia y materiales audiovisuales, objetos de aprendizaje, entre otros. También es conveniente señalar que el archivo de los distintos tipos de recursos en los repositorios, generalmente no se encuentra sujeto a una evaluación, puesto que 
éste es voluntario, siendo los autores los responsable de la calidad de los recursos que se ponen a disposición en AA, aunque algunas instituciones han empezado a establecer políticas de evaluación para la inclusión de los recursos en sus repositorios.

Estas dos vías del AA poseen una serie de implicaciones y responsabilidades para los actores que intervienen en este movimiento, los autores, los editores y los bibliotecarios, las cuales son abordadas en los siguientes apartados de este documento.

\section{Responsabilidades de los Autores}

La principal responsabilidad ética de los autores se encuentra enmarcada en la originalidad e integridad de lo que se publica y en donde se publica. Con respecto al primer punto es importante señalar que:

La ética en la investigación pasó a ser un tema importante en el medio académico-científico, una vez que se constata, cada vez más que estudiantes de grado, estudiantes de posgrado y docentes/investigadores no la [han] practicado como se debe/debería (Valentim, 2015).

Adicionalmente, se menciona lo siguiente sobre este asunto:

Los editores de revistas científicas han sido, tradicionalmente, poco conscientes de la existencia de fraudes y conductas inapropiadas, más preocupados por los temas relacionados con el impacto o con la revisión editorial, pero en los últimos años se ha ido comprobando y denunciando que existen comportamientos inadecuados en el ámbito científico y que además no son infrecuentes [...] Entre las conductas inapropiadas de los autores se incluye una serie de actuaciones de éstos de las que se considera que suponen una vulneración de las condiciones que debe tener un trabajo académico: fraudes como el plagio, las publicaciones repetidas, o las publicaciones redundantes, que son en realidad publicaciones 
repetidas a las que se añade material nuevo no relevante para que parezca otro artículo. Además de estos fraudes, se puede incluir entre las conductas inapropiadas de los autores, aquellas relacionadas con distorsiones y omisiones en la autoría (Matías-Guiu \& García-Ramos 2010)

Por otro lado, una de las alternativas comúnmente utilizadas para validar la integridad y originalidad de los productos de investigación es la revisión por pares, no obstante, existe una gran discusión sobre las ventajas y desventajas de esta opción. Entre sus ventajas se menciona que esta revisión coadyuva a establecer la validez de la investigación, basándose en el conocimiento experto de otros investigadores de la misma disciplina, previniendo por lo tanto la aceptación de trabajos falsificados dentro de un área de estudio, permitiendo además a los editores de revistas seleccionar los resultados de las investigaciones más importantes para su publicación en ellas, basándose en revisiones independientes de un grupo de expertos; además, el proceso de revisión por pares es entendido y aceptado por la mayoría de los investigadores (Kelt, 2016).

Lo anteriormente señalado implica que los autores y las publicaciones en AA deberán seguir los modelos de evaluación existentes para otros tipos de publicaciones, es decir someterse a la revisión por pares. De esta forma, el contenido de las publicaciones en AA tendrá la misma integridad, originalidad y calidad de aquellas publicaciones que se adquieren por suscripción, desmitificando la idea de que las publicaciones en AA son de menor calidad.

Por otro lado, actualmente muchas de las revistas han cambiado su formato de publicación de impreso a electrónico, lo cual puede facilitar la copia, el plagio y otras conductas inapropiadas; sin embargo, actualmente también existen una serie de programas que se pueden utilizar para verificar la integridad y originalidad de un trabajo académico-científico en formato electrónico. Lo anteriormente mencionado implica que los "[...] editores de revistas científicas necesiten de recursos que los auxilien en la verificación de la originalidad de los artículos científicos sometidos, una vez 
que la mayoría de las revistas científicas exigen que el texto sea original, generalmente es uno de los criterios para aceptar un artículo científico" (Valentim, 2015).

No obstante lo anterior, lo más importante es la creación de una conciencia para evitar conductas inapropiadas, a través del establecimiento y la observancia de códigos de ética para los autores, en los que se incluyan una serie de serie de principios que regirán sus acciones, como los incluidos en el siguiente ejemplo:

III. Reportará los hallazgos de su investigación de manera abierta, completa y oportuna a la comunidad científica y compartirá razonablemente sus resultados con otros investigadores.

IV. Describirá sus experimentos tal como los realizó. Mostrará su trabajo, metodología y análisis de la forma más precisa posible.

V. Nunca usará el trabajo de otros como si fuera el suyo propio. Citará adecuadamente las investigaciones relevantes que se hayan publicado previamente (Universidad de los Andes, Venezuela, 2007).

\section{RESPONSABILIDADES DE LOS EDITORES}

Como se ha mencionado anteriormente, otra de las responsabilidades éticas de los autores es en donde publicar, la cual se encuentra estrechamente interrelacionada con las responsabilidades de los editores. En el marco del AA, los autores tienen la opción de publicar en las revistas de este tipo, auspiciadas por las organizaciones o instituciones que apoyan este movimiento, o bien, cubrir un costo por el procesamiento de artículos en las revistas comerciales, a fin de que éstos sean accesibles en la modalidad de AA. El pago de los costos por procesamiento de artículos (CPA), se ha convertido en una de las formas de financiamiento de las publicaciones en AA.

Los grandes editores tienden a desplazar los costos editoriales y de publicación a los autores, a quienes se les pide pagar, en 
ocasiones grandes cantidades para que su artículo se encuentre disponible en AA. A pesar de que el pago para publicar se ha convertido en una norma en ciertas áreas como las ciencias de la salud, para muchos otros sectores de la academia, la idea de pagar por publicar se considera como algo cuestionable. De hecho, muchos todavía ven a esta práctica como éticamente sospechosa, dado la existencia de un aparente conflicto de intereses. Adicionalmente, en un contexto de una creciente competencia por un reducido número de apoyos y la inevitable reducción de presupuestos, la idea de pagar grandes cantidades por el AA de un documento, en lugar del pago a un asistente de investigación o un estudiante de posgrado, puede ser considerado un mal uso de los recursos. Aún más preocupante, los investigadores jóvenes están en desventaja al no contar con los fondos necesarios para publicar los resultados de su investigación en AA, un hecho que puede tener consecuencias negativas para sus carreras académicas (Williams-Jones et al., 2014).

Un estudio efectuado en 2010 por Solomon \& Björk (2012) sobre los montos de los cargos por procesamiento de los artículos (CPA) en 1370 revistas incluidas en el DOAJ (Directory of Open Access Journals), encontró que el promedio del CPA era de 904 dólares americanos por artículo. El rango de CPA se encontraba entre 8 y 3900 dólares, con los costos más bajos para las revistas publicadas en los países en desarrollo y los más altos para las revistas con un alto factor de impacto de las principales editoriales internacionales. Las revistas en Biomedicina tenían los CPA más altos, en comparación con los de otras disciplinas. Las revistas publicadas por organizaciones profesionales, con y sin fines de lucro, tenía CPA más altos que las publicadas por universidades u organizaciones académicas.

Ciertamente, la mayoría de las grandes editoriales comerciales proporcionan ahora una opción para el AA en revistas de suscripción. A través de ésta, los autores pueden comprar el AA a sus artículos, a través de un CPA, pagado por cuenta propia o a través de sus instituciones. Esto bien podría ser una señal de un cambio en los modelos de publicación, lo que definitivamente tendrá 
consecuencias. Si los editores cambian su modelo económico de revistas por suscripción de altos precios, por otro de CPA de altos precios, podrán surgir nuevas presiones sobre los presupuestos de investigación, particularmente para aquellos autores o instituciones que no cuentan con un generoso financiamiento o altos presupuestos (Willinsky \& Alperin, 2011).

Otro problema relacionado es que el modelo de CPA podría reforzar o aumentar las desigualdades entre disciplinas y sectores académicos. Los editores no dudarían en vender el activo de las páginas de su revista, él cual estaría gobernado por el prestigio de ésta o su comercialización entre las disciplinas. Las mayores desventajas serían para las Humanidades y las Ciencias Sociales, en donde los autores suelen recibir menos fondos para apoyar su investigación que su contraparte en las ciencias. Algunos defensores del AA reconocen que las disciplinas más pobres tienen menos probabilidades de beneficiarse del modelo en donde el autor paga. En forma similar, las desigualdades podrían ser reforzadas entre los países y regiones. Los investigadores de los países o instituciones con menos recursos, podrían verse obligados a publicar en revistas de bajo prestigio que cobren CPA reducidos. Adicionalmente, podrían empeorar las posibilidades de oferta de las instituciones que aspiren a contar con investigadores de alto nivel. Las grandes universidades que posean una mayor capacidad para apoyar a sus autores, probablemente estarían en mejores posibilidades de atraer a investigadores más prometedores y productivos (Wellen, 2004).

Sin duda alguna, todo lo anteriormente expuesto muestra una serie de implicaciones éticas que trae consigo el modelo CPA, las cuales necesitan analizarse y discutirse cuidadosa y ampliamente.

Por otro lado, un problema que también posee connotaciones éticas son las editoriales que han encontrado en el AA y en la necesidad de los autores de publicar, una nueva forma de negocio, a través del modelo donde el autor paga, pero siendo menos exigentes en cuanto a la calidad del contenido de las publicaciones, no siendo éstas evaluadas por pares, lo que incide en 
su calidad. Estas editoriales y publicaciones son conocidas comúnmente como editoriales y revistas predatorias.

El objetivo de los editores de este tipo de revistas es solamente la obtención de CPA y proporcionar una edición rápida, sin una adecuada revisión por pares para los autores que necesitan publicaciones en su currículum vitae. La información que incluyen los editores de estas publicaciones en Internet es a menudo muy engañosa, y éstos continuamente envían correo no deseado a los académicos a nivel global, solicitándoles los resultados de su trabajo de investigación para publicarlos, o bien, para formar parte de sus cuerpos editoriales. Este tipo de editores y publicaciones han causado una publicidad negativa para las publicaciones de AA, debido al constante uso del correo electrónico no deseado para comunicarse con los investigadores y a una serie de escándalos que involucran manuscritos con deficiencias académicas que supuestamente han pasado por un control de calidad (Shen \& Björk, 2015).

En relación con este tipo de editores y publicaciones, anualmente desde el año 2011 a la fecha, Beall (2016) ha compilado una lista que incluye a éstos, denominada Beall's List of Predatory Publishers, en la cual el número de éstos se ha ido incrementando año con año. En 2016 se reportan los siguientes datos sobre el número de editores cuestionables: 2011, 18; 2012, 23; 2013, 225; 2014, 477; 2015, 693; 2016,293. En esta lista de editores cuestionables se recomienda que los académicos lean cuidadosamente las reseñas, las evaluaciones y la información proporcionada para decidir sobre el envío de sus manuscritos, o sobre su participación en los comités editoriales de ellos. Asimismo, se incluye una serie de criterios para la calificación de estos editores, basados en dos documentos del Committee on Publication Ethics, COPE: 1) "Code of Conduct for Journal Publishers (COPE, 2011) y 2) Principles of Transparency and Best Practice in Scholarly Publishing (COPE, 2015). Este organismo, fue establecido en 1997 por un pequeño grupo de editores de revistas médicas del Reino Unido y actualmente cuenta con más de 10000 miembros de diferentes áreas académicas en todo el mundo. La membresía es abierta para los editores de revistas académicas y otros interesados en la 
ética de las publicaciones. COPE proporciona asesoramiento a los directores y editores en todos los aspectos de la ética de las publicaciones, y en particular, en cómo manejar los casos de prácticas inadecuadas en investigación y publicaciones (COPE, 2016).

\section{Responsabilidades De los Bibliotecarios}

El tercer actor con un importante papel y responsabilidades éticas trascendentales dentro del movimiento del AA son los bibliotecarios. La IFLA (2011) en el documento Declaración de la IFLA sobre el acceso abierto - definición de su posición y política, señala lo siguiente con respecto al papel de las bibliotecas dentro del movimiento del AA.

El acceso abierto es uno de los pilares centrales del Plan Estratégico 2010-2015 de la IFLA, en el cual las opciones de acción de todas las organizaciones son tomadas en cuenta para integrarlo dentro de la agenda y actividades actuales y futuras de la IFLA.

La IFLA recomendará a sus asociaciones miembros:

- Promover el acceso abierto en las políticas nacionales.

- Estimular a las bibliotecas miembros a promocionar el acceso abierto en sus comunidades, y a implementar medidas para incrementar su impacto.

-Enriquecer la infraestructura de información local y nacional para estimular el acceso abierto.

- Brindar asistencia en la elaboración de políticas nacionales relativas al acceso abierto al conocimiento, así como a la investigación efectuada con fondos públicos y al patrimonio cultural.

- Apoyar a las organizaciones, programas, iniciativas y servicios que están trabajando por la promoción del acceso abierto (IFLA 2011).

La puesta en marcha de estas recomendaciones requiere un papel activo de los bibliotecarios y de asumir sus responsabilidades. 
Adicionalmente, el Código de ética de la IFLA para bibliotecarios y otros trabajadores de la información señala lo siguiente en relación con el papel de los bibliotecarios dentro del AA:

El interés de los bibliotecarios y otros trabajadores de la información es proporcionar a los usuarios el mejor acceso posible a la información e ideas en cualquier medio o formato. Esto incluye el apoyo a los principios del acceso abierto, código abierto, y licencias abiertas [...] Los bibliotecarios y otros trabajadores de la información son socios de autores, editoriales y otros creadores de obras protegidas por copyright. Los bibliotecarios y otros trabajadores de la información reconocen el derecho de la propiedad intelectual de los autores y otros creadores y buscarán asegurarse de que sus derechos sean respetados (IFLA 2012).

Por otro lado, Pontika (2010) señala como una responsabilidad ética de los bibliotecarios la educación formal e informal de los aspectos relacionados con el AA a los profesores de las universidades, los administradores, el personal de los departamentos de publicaciones y los de comunicación académica. Asimismo, resalta el papel de los bibliotecarios encargados de tareas relacionadas con las revistas, quienes deberán conocer como se evalúan éstas, estar familiarizados con las prácticas de publicación, tener conocimiento de los recursos en Acceso Abierto que apoyan a la investigación, así como los asuntos relacionados con derechos de autor y licenciamientos.

Las responsabilidades de los bibliotecarios frente al AA mencionadas anteriormente, implican una formación en esta materia, por lo que la UNESCO en marzo de 2015, publicó un programa y materiales para la enseñanza del AA en las escuelas de bibliotecología y entre los investigadores. La parte correspondiente a las escuelas de bibliotecología se enfoca la preparación de los bibliotecarios para la promoción del AA, la comunicación científica y el AA, así como sobre la organización y manejo de recursos de AA en las instituciones. La parte correspondiente al programa destinado a los investigadores aborda conceptos relacionados con el proceso 
de la comunicación científica, tendencias del AA, derecho de autor y propiedad intelectual, así como métricas para la evaluación de la investigación científica.

\section{Consideraciones Finales}

Sin lugar a dudas, el movimiento del AA representa una nueva alternativa en la comunicación científica, conservando una serie de responsabilidades éticas que tradicionalmente han tenido los autores, los editores y los bibliotecarios, e inclusive los usuarios en general, aunque también han emergido otras nuevas.

Para los autores, la principal responsabilidad se encuentra relacionada con la calidad de lo que se publica, siendo necesario ofrecer resultados originales. Por lo anterior, la evaluación de las publicaciones por pares continúa siendo una necesidad para lograr la calidad del contenido de las publicaciones en AA. Adicionalmente, la responsabilidad de dar crédito y citar adecuadamente a los autores de las publicaciones en AA es otra responsabilidad de los autores, y también es inherente a todos sus usuarios.

Por otro lado, los editores de publicaciones y revistas científicas han creado nuevos modelos de publicación, incluyendo artículos en AA, cuando el autor paga por ello. Sin embargo, esto se ha desvirtuado, apareciendo editores de dudosa calidad, cuyo único fin es el comercial, dejando de lado, la calidad de las publicaciones. Lo anterior implica la identificación de la calidad de los editores y revistas en AA.

Adicionalmente, para los bibliotecarios, el movimiento del AA ha acentuado la necesidad de formar y orientar a las comunidades académicas y científicas sobre las características de esta nueva opción de publicación, así como sobre el tipo y características de las publicaciones en AA, con la finalidad de apoyarlas en la selección y recomendación sobre la calidad de las publicaciones de este tipo y en cuales escribir.

Asimismo, es importante resaltar que el movimiento del AA también ha traído consigo la necesidad de desarrollar o adecuar 
los códigos de ética de los autores, los editores y los bibliotecarios. Finalmente, no puede dejarse de lado el surgimiento de la necesidad de formar y actualizar a los bibliotecarios en asuntos relacionados con las publicaciones en AA, vislumbrándose la necesidad de la formación de un nuevo profesional, con un perfil de editor y bibliotecólogo.

\section{BiBLIOGRAFÍA}

Beall, J. (2016). Beall's List of Predatory Publishers 2016. Scholarly Open Access: Critical Analysis of Open-Access Publishing. Disponible en: <https:// scholarlyoa.com/2016/01/05/bealls-list-of-predatorypublishers-2016/>.

COPE (2016). Committee on Publication Ethics. Promoting Integrity in Research Publication. Disponible en: $<$ http://publicationethics.org/>.

-_- (2015). Committee on Publication Etbics. Principles of Transparency and Best Practice in Scholarly Publishing. Version 2. Disponible en: <http:// publicationethics.org/resources/guidelines-new/ principles-transparency-and-best-practice-scholarlypublishing $>$.

-_- - (2011). Committee on Publication Ethics. Code of Conduct. Disponible en: <http://publicationethics.org/ resources/code-conduct $>$.

Díaz Vargas, O., E.V. González de la Rosa, J. Hernández Ortega, L.E. Ramírez Lazcano Y A.R. Xoletl Sánchez. (2009). Conducta ética y responsabilidad social. Disponible en: <http://es.slideshare.net/terceroithebest/ conducta-etica-y-responsabilidad-social $>$. 
IFLA (2011). International Federation of Library Associations and Institutions. Declaración de la IFLA sobre el acceso abierto-definición de su posición y politica. Disponible en: <http://www.ifla.org/files/assets/hq/news/ documents/ifla-statement-on-open-access-es.pdf $>$.

-_—— (2012). Código de ética de la IFLA para bibliotecarios y otros trabajadores de la información. Disponible en: <http://www.ifla.org/files/assets/faife/ codesofethics/spanishcodeofethicsfull.pdf $>$.

Iniciativa de Budapest para el Acceso Abierto (2002). Disponible en: <www.budapestopenaccessinitiative.org/ translations/spanish-translation>.

Kelt, M. (2016). The Publication Process: Advantages and Disadvantages of Peer Review. PILOT: Postgraduate Information Literacy Online Training. Disponible en: $<$ www.gcu.ac.uk/library/pilot/publication/peerreview /advantagesanddisadvantages/>.

Matías-Guiu, J. y R. García-Ramos. (2010). "Fraude y conductas inapropiadas en las publicaciones científicas." Neurología, vol. 25 núm. 1. Disponible en: <www. elsevier.es/es-revista-neurologia-295-articulo-fraudeconductas-inapropiadas-las-publicaciones-13148433>.

Parke, M. (2013). "The Ethics of Open Access Publishing." BMC Medical Ethics, vol. 14, 16 p. Disponible en: $<$ bmcmedethics.biomedcentral.com/articles/10.1186/ 1472-6939-14-16>.

Pontika, A. (2010). The Ethics of Open Access. Disponible en: <scholarworks.umass.edu/cgi/viewcontent.cgi? article $=1003 \&$ context $=$ ethics_day $>$. 
UNESCO (2015). UNESCO's Open Access (OA) Curriculum is Now Online. Disponible en: <www.unesco.org/new/ en/communication-and-information/resources/newsand-in-focus-articles/all-news/news/unescos_open_ access_oa_curriculum_is_now_online/\#.V3HOfuvhDIX $>$.

Shen, C. y B. Björk. (2015). "Predatory open access: a longitudinal study of article volumes and market characteristics." BMC Medicine Open Peer Review reports, vol. 13, núm. 230. Disponible en: <bmcmedicine. biomedcentral.com/articles/10.1186/s12916-015-04692\#Sec5>.

Solomon, D. J. y B.C. Björk. (2012). "A study of open access journals using article processing charges." Journal of the American Society for Information Science and Technology, vol. 63 núm.8, 1485-1495. Disponible en: <http://onlinelibrary.wiley.com/doi/10.1002/ asi.22673/abstract>.

Suber, P. (2004). A very brief introduction to Open Access. Disponible en: <http://legacy.earlham.edu/ peters/fos /brief.htm>.

(2008). Welcome to the SPARC Open Access Newsletter: Open access and the self-correction of knowledge. núm. 122. Disponible en: <legacy.earlham.edu/ $\sim$ peters/fos/newsletter/06-02-08>.

Universidad de los Andes, Venezuela (2007). Codigo de ética del investigador: Día de la Ética Médica 2007. Disponible en: <http://www2.ula.ve/cdcht/ dmdocuments/codigo_etica_investigador.pdf $>$. 
Valentim, M. (2015). La cuestión del plagio en el entorno académico y científico. Disponible en: <www.filo.uba. ar/contenidos/investigacion/institutos/inibi_nuevo/ plagiovalentim.pdf $>$.

Wellen, R. (2004). "Taking on Commercial Journals: Reflections on the 'Open Access' Movement." Journal of Academic Ethics, vol. 2 núm. 1, 101-118. Disponible en: $<$ www.yorku.ca/rwellen/works/open_access.html>.

Williams-Jones, B., J.C. Belisle Pipon, J. Smith y R. Boulanger. (2014). "Ethical challenges of open-access publishing." University Affairs. Disponible en: <www. universityaffairs.ca/opinion/in-my-opinion/ethicalchallenges-of-open-access-publishing/>.

Willinsky, J. y J.P. Alperin. (2011). "The Academic Ethics of Open Access to Research and Scholarship." Ethics and Education, vol. 6 núm. 3, 217-223. Disponible en: <http://dx.doi.org/10.1080/17449642.2011.63271>. 


\title{
Ética en las revistas científicas mexicanas: proceso de arbitraje y políticas de derecho de autor
}

\author{
Jenny Teresita Guerra GonZÁlez \\ Instituto de Investigaciones Bibliotecológicas y de la Información, \\ Universidad Nacional Autónoma de México, México
}

\section{INTRODUCCIÓN}

T a ética ha sido un aspecto abordado regularmente por estudiosos en los campos disciplinarios de la filosofía, la psicología y la sociología debido a su carácter medular en la triada: comunidad-individuo-conocimiento. Comprende investigaciones referentes a la moral, entendida como el conjunto de normas, valores y creencias cuyo objetivo es ser un modelo de conducta y valoración para establecer lo que es tolerable y lo que no lo es dentro de un núcleo social (Rodríguez, Mesa y Álvarez, 2006). Así la necesidad de crear una conciencia moral entre los hombres, ha motivado que a lo largo de la historia se hayan diseñado instrumentos de ética orientados a concertar y viabilizar las relaciones humanas.

Al hablar de ética estamos aludiendo a la disciplina que estudia la sistematización, defensa, y recomendación de los conceptos del buen y el mal comportamiento (Internet Encyclopedia of Philoso$p h y, 2016)$. La ética actúa como una teoría del deber ser que explica la moralidad y a la que no atañe establecer reglas efectivas de conducta pero sí proporcionar una base de la que éstas puedan deducirse (Russell, 1972). Según exponen Cortina y Martínez: 
[...] corresponde a la ética una triple función: 1) aclarar qué es lo moral, cuáles son sus rasgos específicos; 2) fundamentar la moralidad, es decir, tratar de averiguar cuáles son las razones por las que tiene sentido que los seres humanos se esfuercen en vivir moralmente y 3) aplicar a los distintos ámbitos de la vida social los resultados obtenidos en las dos primeras funciones, de manera que se adopte en esos ámbitos sociales una moral crítica (es decir, racionalmente fundamentada [...] (Cortina y Martínez, 2008: 23).

La ética alcanza múltiples aristas de la vida social del ser humano. Perceptible en la práctica laboral, la actividad económica y la educación, el quehacer científico es ampliamente contemplado en su horizonte de acción.

La publicación de revistas científicas como práctica de la actividad de información científico investigativa se encuentra sujeta a distintos procedimientos éticos que involucran la totalidad de sus procesos editoriales. Al incumplir estos procedimientos o normas se cae en la denominada mala conducta científica (scientific misconduct), conjunto de faltas graves como el fraude científico y prácticas menores vinculadas al proceso de publicación (Bravo, 2010). Las malas conductas producidas en el proceso editorial de una revista se clasifican acorde a quienes las cometen, ya sean autores, editores y/o evaluadores. En este trabajo nos centramos en las figuras de los autores y los evaluadores ahondando para ello en el proceso de arbitraje y las políticas de derechos de autor de una muestra de revistas mexicanas de ciencia. Ambas fases de publicación representan ejercicios de ética normativa y permiten esbozar la situación que atraviesan actualmente en el país.

\section{ÉTICA NORMATIVA Y REVISTAS CIENTÍFICAS}

Como una de las ramas principales de la ética, la ética normativa auxilia en la formulación de juicios sobre la corrección o bondad moral de acciones e instituciones (Camps, Guariglia y Salmerón, 2004). Específicamente, este tipo de ética busca proveer guías de 
acción y procedimientos para responder a la pregunta: ¿Qué debo hacer? Está orientada a la definición de estándares prácticos morales para distinguir lo correcto de lo incorrecto, las obligaciones y lo permitido, proponiendo códigos morales y reglas encaminados a determinar el contenido del comportamiento (Castillo s/a).

El establecimiento de variados procedimientos e instrumentos de ética normativa obedece en la actualidad a dos enfoques antagónicos: el llamado enfoque de cumplimiento (compliane approach) y el enfoque de integridad (integrity approach). La primera vertiente aboga por la institución de un sistema de incentivos y castigos de tal forma que las personas se ven obligadas a cumplir las normas. Contrariamente, el enfoque de integridad persigue el compromiso voluntario de los individuos con unos valores compartidos que han sido fruto del consenso (Lozano Aguilar, 2007).

La meta del enfoque de cumplimiento es prevenir la conducta criminal e ilegal que pueda ocasionar problemas con las autoridades judiciales. Considera que las personas son sujetos guiados únicamente por su propio interés material. En tanto, el objetivo del enfoque de integridad es favorecer la conducta responsable de las personas. Para el caso de la comunicación científica, durante los últimos veinte años se han institucionalizando y estandarizando herramientas que permiten promover y a la vez sancionar, aquéllas prácticas que son consideradas no éticas y que competen directamente a las revistas, sus autores, colaboradores y procesos.

Hoy en día se cuenta a nivel mundial con tres instrumentos normativos que, con distinto nivel de compromiso, las publicaciones incorporan para hacer de conocimiento público las condiciones que permean sus procesos editoriales. Éstos se enlistan a continuación, iniciando con aquéllos instrumentos que implican un mayor rigor y legitimación:

- Código de ética: Conjunto de normas tendientes a regular el comportamiento de las personas dentro de un determinado contexto; como puede ser el de una profesión, organización o institución. Si bien la ética no impone castigos efectivos cuando alguien se desvíade la propuesta de comportamiento que 
ésta aconseja, el código opera como una normativa de carácter obligatorio (Lozano Aguilar, 2007).

Las normas que aglutina un código de ética se alinean con las normas legales vigentes en un determinado lugar. Ayudan a determinar patrones y expectativas conductuales y son de carácter público. El propósito de cualquier código de ética, con independencia de su contexto, es mantener una línea de comportamiento uniforme entre los interesados (Código de Ética, 2016; Lozano Aguilar, 2007).

En el ámbito de las revistas científicas "la existencia de un código ético manifiesta la concienciación, asegura la prevención del fraude científico y orienta sobre el procedimiento en casos de mala praxis" (Viñes et al., 2012: 492). Los códigos de ética se diseñan según la visión, misión y objetivos de cada publicación. Ellos reúnen lo ideal; sin embargo, no siempre se cumple como se planifican. Los beneficios que implica el cumplimiento del código de ética se manifiestan en el rendimiento de cada actividad, así como en el incremento de la productividad, visibilidad e impacto de cada uno de los servicios brindados por la revista (Rodríguez, Mesa y Álvarez, 2006).

- Directrices de ética: Conjunto de pautas escritas o verbales que deben seguirse para la consecución de un fin. Son normas específicas derivadas o subordinadas a un código de ética o reglamentación mayor (White Paper on Publication Ethics, 2012).

- Malas prácticas: Orientan la toma de decisiones para solucionar incidencias relacionadas con la publicación, son estrictamente punitivas. Funcionan como contrarespuesta a las buenas prácticas, a las que consideran aspiracionales, por la dificultad de su cumplimiento íntegro (Code of Conduct and Best Practice, 2011).

La necesidad de poner en marcha alguno de estos instrumentos del enfoque de cumplimiento, en la publicación de revistas científicas, obedece entre otras causas a lo expuesto a continuación: 
[...] una publicación en una revista científica puede no asegurar que lo difundido proceda de investigaciones solventes, autores responsables, evaluadores competentes y editores imparciales. El caso Hwang en la revista Science descrito por Delgado-López-Cózar, et al. (2007) donde los datos fueron inventados y nunca se llegó a clonar un embrión, o el reciente caso Doñana1 en el que un investigador alteró e inventó datos en diferentes estudios sobre aves durante años, reclaman mecanismos basados en la transparencia, veracidad y credibilidad de la publicación. (Tur-Viñes, et al., 2012: 492)

Proceso de arbitraje y políticas de Derechos de autor COMO EJERCICIOS ÉTICOS

Socialmente se demanda conducta ética tanto de los científicos e investigadores como de las instituciones editoras de las revistas científicas. Los primeros deben desarrollar una ética profesional que rija su conducta moral por medio de estándares (deberes morales) que han de ponerse en práctica ante determinadas situaciones (Rodríguez, Mesa y Álvarez, 2006). Las organizaciones que editan y/o publican revistas aparecen como el marco formal de la comunicación científica idóneo para garantizar la integridad de sus procesos y contenidos. Para ello, éstas últimas requieren trasladar elementos del ethos de la ciencia a su quehacer editorial. Es así que los principios de comunidad, universalidad, escepticismo organizado e imparcialidad establecidos han de permear a la 
publicación científica ética ${ }^{1}$ (Merton, 1942: 115).

El proceso de arbitraje o peer review se entiende como un sistema de evaluación crítica y constructiva de los resultados de un artículo científico a cargo de sus pares: comprende la actividad de los revisores, quienes se ocupan en determinar si un trabajo merece o no ser publicado (Silva, 2011). En la gran mayoría de los casos, los revisores o evaluadores de las publicaciones no perciben una compensación económica por sus servicios; siendo sus únicos beneficios: el conocer novedades antes que nadie; aparecer como evaluador en los créditos de la revista, sea formando parte de un Comité Científico asesor fijo, y/o en una lista de evaluadores que se publica anualmente (Baiget, 2010).

Considerando que la elección de los revisores, es una de las tareas eje de los editores de las publicaciones científicas, estos se encuentran en la obligación de contar con una nutrida cantera de evaluadores representativa de las temáticas que aborda su revista y que además hayan aceptado colaborar. A esto se suma: a) el diseño

1 El principio de comunidad alude a que la ciencia generalmente es realizada por investigadores que trabajan dentro de un marco institucional en organizaciones académicas y de investigación públicas o privadas. Una hipótesis se considera científica cuando es comprobable por otros investigadores que pueden replicar ese experimento. Este principio exige que el investigador se involucre en el trabajo de otros, publique su propio trabajo, se mantenga al día sobre los avances técnicos y científicos y lleve a cabo mejores prácticas científicas. Cuando se habla de universalidad en la ciencia es bajo el argumento de que la verdad no es exclusiva de ninguna cultura, tiempo o lugar, sino que de alguna manera es inherente a la naturaleza misma y alcanzable por distintos métodos. Mientras que el escepticismo organizado consiste en la obligación de los científicos de mantener una postura escéptica, incluso sobre las teorías establecidas, y ser conscientes de que el conocimiento científico es siempre contingente, por lo que la labor de probar y verificar el corpus del conocimiento es un deber permanente. La imparcialidad, por otro lado, es el principio que pugna porque los estudios científicos se realicen sin presupuestos sobre su resultado. Solo a través de una labor continua, desafiando y haciendo pruebas, se confirma una teoría. La ciencia debe avanzar lento ya que a largo plazo es preferible para las instituciones y sus participantes (Koepsell y Ruiz de Chávez, 2015: 14, 84-87, 127-28, 131-132). 
de normas para autores que especifiquen de manera clara el proceso de evaluación y revisión de originales así como la transparencia informativa sobre el mismo; b) creación de los protocolos de evaluación y c) la esquematización del formulario de evaluación para los dictaminadores.

Los protocolos de evaluación aseguran que tanto los revisores como los autores conozcan los criterios que se utilizan en la revisión de los artículos. Son redactados en términos de instrucciones que incluyen aspectos técnico-formales; de contenido; mejora de la presentación formal y los contenidos científicos; cómo se debe formular la decisión final y recomendación sobre la prioridad en la publicación (Ruiz Pérez, 2008).

Los procedimientos en el arbitraje científico varían de acuerdo al tipo de manuscrito, de revista y de la disciplina a la que pertenezca. Adquiere distintas formas, siendo las más utilizadas:

- Revisión simple ciego: se mantiene en secreto la identidad de los revisores, inclusive después de la publicación del artículo.

- Doble ciego: sistema que emplea dos revisores por artículo. Cuando su dictamen no coincide, el documento es enviado a un tercer evaluado. En esta modalidad, autores y evaluadores no se conocen. Los autores nunca sabrán quien les revisó su artículo y los evaluadores solo conocerán el nombre del autor cuando se publique el documento. Generalmente el sistema funciona bien aunque con frecuencia ocurren problemas de homogeneización y disparidades de criterios.

- Revisión abierta (open review): En este tipo de evaluación, los autores conocen la identidad de los revisores y viceversa, reduciéndose con ello el sesgo. De igual modo, aumenta la transparencia del proceso; las críticas son más respetuosas y constructivas. Los revisores pueden tener el reconocimiento directo por el trabajo implicado en la realización de la revisión y quizá lo más relevante: el hecho de indicar y advertirle al autor que la evaluación será objeto de un escrutinio abierto factible de evidenciar posibles plagios. En la revisión abierta se comparte la responsabilidad de la aceptación de un artículo 
Uso ético de la información...

entre el autor, el editor y los revisores (Mora, 2015; Coslado, Lacunza y Ros, 2011: 160; Nassi-Caló, 2015).

De acuerdo con Hames (2012: 23-24), los requerimientos de un buen sistema de arbitraje, independientemente de su tipo, son:

- La evaluación debe involucrar a revisores externos.

- El sistema debe ser justo y sin prejuicios ya sea que los dictámenes sean positivos o negativos.

- Se mantendrá la confidencialidad para cualquier aspecto que no opere bajo revisión abierta.

- Contar con sistemas y orientación para permitir a los revisores proporcionar calidad y retroalimentación constructiva, tanto para el editor como para los autores.

- Basar la toma de decisiones únicamente en los méritos de la obra, no influenciada por los autores que son o de dónde vienen y no se deben a consideraciones comerciales.

Esta serie de precisiones trae a colación asuntos del deber ser que son preocupantes dicotomías para las revistas científicas. Uno de ellos es el criterio de reconocimiento por parte de los revisores sobre su escasa disposición para la evaluación, lo que les obligaría a no aceptar esta tarea, pero entonces las publicaciones carecerían de evaluadores y los tiempos de edición serían muy largos. Otra falta de ética sería que un revisor recomiende el rechazo de un artículo porque los hallazgos contradicen su investigación, cayendo hasta cierto punto en el sesgo de publicación.

El arbitraje científico es parte fundamental para el mantenimiento de la calidad, confiabilidad, integridad y consistencia de la investigación científica. Los modos o formas que adquiere en cada revista, son opciones particulares que deben decidirse considerando a la comunidad de autores, editores y lectores. Tras una serie de escándalos relacionados con el proceso de arbitraje en publicaciones de editoriales científicas prestigiosas como Springer, Wiley, Taylor \& Francis, PLoS, entre otras, la revista Nature publicó a comienzos de 2015 una serie de indicadores (tips) a los editores 
que podrían ser signos de alerta de que el autor estaría intentando usar a su favor fragilidades del sistema automatizado de control de arbitraje. Lo anterior es para asegurar que el revisor de sus trabajos pueda ser él mismo, o alguno de sus conocidos a quienes ha recomendado (Spinak, 2015). Los indicadores propuestos por $\mathrm{Na}$ ture son los siguientes:

-El autor solicita la exclusión de algunos árbitros y suministra en una lista la mayoría de los científicos del área.

-El autor recomienda como revisores a personas que no se encuentran fácilmente online.

-El autor suministra direcciones de e-mail en Yahoo o Gmail, y no en direcciones de instituciones académicas.

-Los artículos enviados al revisor son retornados en tiempos muy breves, a veces solamente en horas (Spinak, 2015).

La politica de derechos de autor (copyright) se enmarca en la ética de los editores y los autores, entendiéndose como la suma y administración de tres principios universales: 1) el derecho de autor protege la creación de formas; 2) la forma debe ser original y 3) la indiferencia del destino de las obras (Colombet, 1997). Baiget (2010) sostiene que la tarea primordial de los editores es encontrar buenos artículos, innovadores e interesantes a fin de que cuando la revista sea más conocida y esté indizada en las grandes bases de datos, recibir buenos artículos sea un asunto zanjado. Empero, los derechos de autor en la investigación factible de ser publicada, son un tema que debe acompañar esta labor tanto en términos de: referenciar las investigaciones o contribuciones de otros; reconocer la autoría de terceros; hacer uso de los materiales propios en diferentes lugares y plataformas o ceder los derechos patrimoniales de su publicación a otros.

Los derechos de autor son el conjunto de normas y principios que regulan los derechos de los autores, por el simple hecho de crear una obra, haya sido publicada o permanezca inédita. Los derechos autorales tienen una doble naturaleza, moral y patrimonial. 
Específicamente, los derechos morales actúan como reconocimiento de la paternidad del autor sobre una obra realizada y la integridad de la misma. Confieren al sujeto facultades como:

- Exigir que su nombre y el título de la obra sean mencionados cada vez que ésta se utilice, publique o divulgue.

- Oponerse a las transformaciones o adaptaciones de la misma si esto afecta su buen nombre o reputación.

- Dejar la obra inédita o publicarla en forma anónima o bajo un seudónimo.

- Modificar la obra en cualquier tiempo y retirarla de la circulación, previo el pago de las indemnizaciones a que haya lugar.

Los derechos morales aparecen en el momento mismo de la creación de la obra sin necesidad de registro. Pertenecen al autor de manera personal e irrenunciable y no pueden enajenarse, ni embargarse, no prescriben y son de duración ilimitada.

Por otra parte, los derechos patrimoniales son la facultad de aprovecharse y de disponer económicamente de la obra por cualquier medio. Las formas de utilización de una obra -independientes entre sí- son: la copia, la reproducción, la presentación pública, la traducción, la adaptación, etc. Sobre estas formas de utilización, el autor o titular de los derechos patrimoniales puede ceder (entregar los derechos a otra persona) o autorizar su uso (dar un permiso pero sin ceder los derechos) para cada una de ellas considerando límites de tiempo, cobertura y retribución económica.

- Para ceder los derechos patrimoniales se requiere la firma de un documento (público o privado) entre las partes y del registro de la obra ante la institución encargada de los derechos de autor en el ámbito geográfico del autor;

- Para autorizar determinados usos, sólo se requiere explicitar las condiciones en una licencia o texto con la voluntad del autor o titular de los derechos patrimoniales. 
En el ámbito de las revistas académicas y científicas es indispensable que como parte de su política editorial, quede explícita la gestión de los derechos de autor tanto en las normas para autores y los contratos como en los cintillos legales que acompañan cada uno de sus números, sean digitales o impresos. Y como se sostienen a continuación:

The legal principles that apply to copyright and contract are implicated at every step of the publishing process, from the moment a work is created through the time it is in the hands of the researcher, scholar, student, librarian or reader for whom it is intented. Distribution of digital works is accomplished through contracts such a suscription access or license agreements. Others sets of rights are provided, by contract, to local distributors, translators and services that authorise certain activities such as internal distribution or document delivery of individual journal articles. Legal issues such as copyright, contracts and licenses, and piracy and enforcement, are fundamental to entrerprise regardless of whether a publisher is a comercial or a non-profit organisation. To maintain this business it is necessary to manage rights properly, including on occasion, by enforcing rights when there is unauthorised harmful use being made (Seeley y Wasoff, 2012: 355-356).

El tema de las cesiones entre autor y editorial, entendido como el acuerdo entre dos partes en las que se establecen los términos de reproducción, distribución y uso de esa publicación, es uno de los puntos cruciales a tratar. La cesión de derechos tiene variados matices en que: a) la revista retiene el copyright de las contribuciones; b) el copyright queda en manos del autor y c) el autor y la revista comparten los derechos (Melero, 2008).

Uno más de los tópicos ligados a los derechos de autor en las revistas que no hay que pasar por alto, es el que tiene que ver con las notas editoriales y retracciones que algunas veces han de hacer los autores. El no atender estos fenómenos puede influir en la legitimidad científica de la publicación y en el desarrollo de la investigación en su conjunto. 
Es importante precisar que no existe un copyright internacional. Solo es posible establecer algunas declaraciones generales acerca de qué derechos y qué trabajos son cubiertos por éste. Siempre será necesario recurrir a las legislaciones nacionales para aclarar qué aspectos se incluyen como parte de los derechos de autor en un contexto en particular.

\section{Metodología}

La metodología seleccionada fue de índole cualitativa-inductiva por tratarse de una investigación empírica. Es cualitativa en tanto sus conceptos son orientativos, abiertos y en construcción y el alcance de sus resultados es específico. El diseño de investigación es inductivo porque permite flexibilidad para incorporar hallazgos que no se habían previsto inicialmente y que ayudan a entender mejor el fenómeno estudiado (Corbetta, 2007: 42). El método elegido consistió en la codificación y categorización de datos que faculta la comparación entre y dentro categorías o casos; facilita la generalización por comparación constante, límites de los datos y de la muestra y permite la comparación transversal (Flick, 2015: 149-150).

La ejecución de la investigación fue llevada a cabo en tres fases. En la primera de ellas se definió la muestra de revistas científicas mexicanas a estudiar, por lo que fueron censadas y agrupadas en disciplinas, las revistas incluidas en el Índice de Revistas Mexicanas de Investigación Científica y Tecnológica del Consejo Nacional de Ciencia y Tecnología de México (Conacyt). Se eligió esta muestra porque es representativa de la producción científica del país en términos disciplinarios y de calidad.

Posteriormente se revisaron las políticas editoriales de éstas publicaciones con el objetivo de identificar la presencia de algunos de los siguientes instrumentos de ética normativa: declaraciones de ética, códigos de ética y/o buenas prácticas cuyo contenido abordara el proceso de arbitraje y las políticas de derechos de autor.

En una tercera fase se analizaron a detalle los instrumentos de ética normativa enfatizando sus alcances y limitantes en materia 
de obligaciones y responsabilidades. También se corroboró si éstas normativas se sustentan en reglas institucionales de las entidades responsables de la publicación de la revista y/o en códigos éticos internacionales propios del campo disciplinario al que pertenecen.

\section{Resultados}

El Índice de Revistas Mexicanas de Investigación Científica y Tecnológica del Conacyt consta hasta marzo de 2016 con 137 publicaciones periódicas distribuidas en ocho áreas de conocimiento. La más nutrida corresponde a las Ciencias Sociales con 50 títulos mientras que las áreas que incorporan menos revistas son Medicina y Ciencias de la Salud y Multidisciplinarias con 5 cada una. El resto de las disciplinas presenta este número de títulos: Físico, Matemáticas y Ciencias de la Tierra (11); Biología y Química (14); Humanidades y Ciencias de la Conducta (32); Biotecnología y Ciencias Agropecuarias (9); Ingenierías (11).

Una vez completado el censo y sistematización de las revistas del Índice, se procedió a comprobar que las publicaciones incluyeran, como parte de sus políticas editoriales, alguno de estos tres instrumentos de ética normativa: 1) declaraciones de ética, 2) códigos de ética o 3) relación de malas prácticas que aludan directamente a los procesos de arbitraje y políticas de derechos de autor. El cuadro 1, que aparece en la siguiente página, compila los datos obtenidos por área de conocimiento e instrumento de ética. 
Uso ético de la información...

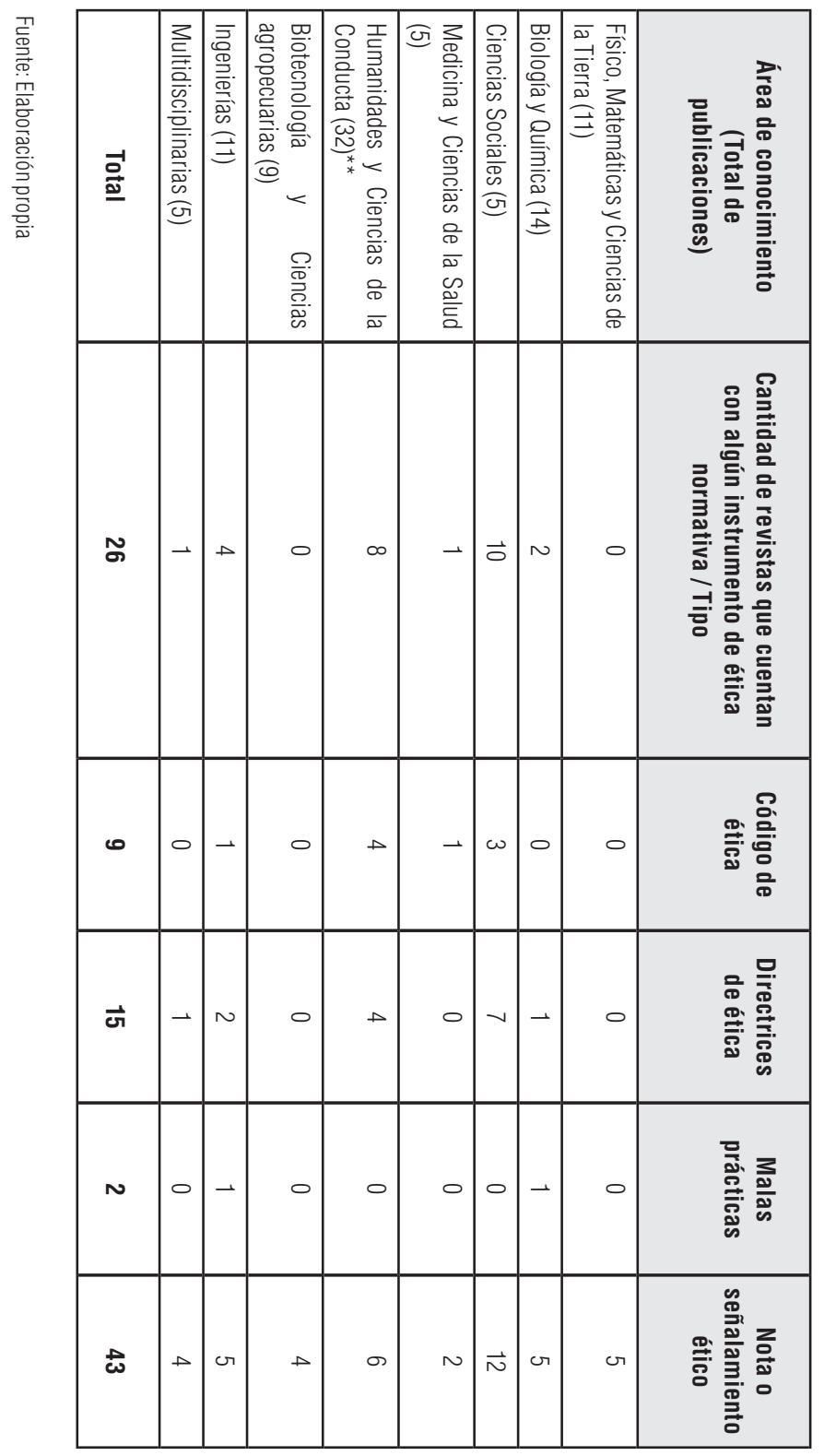

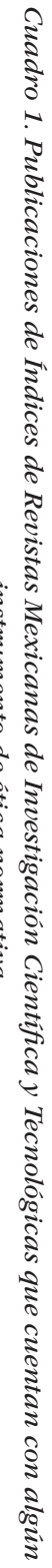


Se encontró que de 137 revistas vigentes en el Índice de Revistas Mexicanas de Investigación Científica y Tecnológica únicamente 26 regulan el comportamiento ético de evaluadores y autores mediante algún instrumento formal de ética normativa. Esto representa un $\mathbf{1 8 . 9 7 \%}$ del total de las publicaciones que en México son consideradas de calidad y que reúnen parámetros editoriales internacionales.

Las directrices de ética son el instrumento normativo mayormente empleado por las revistas del Índice, destacando su uso por las publicaciones del área de Ciencias Sociales. A este instrumento le siguieron en utilización, los códigos de ética aplicados básicamente en Humanidades y Ciencias de la Conducta. Es destacable que las revistas se decanten por las directrices de ética y no por los códigos, que son herramientas de más amplia envergadura, aunque este fenómeno puede entenderse como un paso previo en materia de ética editorial.

La totalidad de revistas publicadas por El Colegio de México y el Instituto de Investigaciones Jurídicas de la UNAM (7 y 6 respectivamente) cuentan con algún instrumento de ética normativa. Esto se explica porque ambas instituciones han diseñado reglamentaciones encaminadas a regular el comportamiento y la integridad académica de sus miembros que es extensiva a sus productos editoriales (Principios éticos, 2016).

Si bien, este trabajo buscó identificar la incorporación de instrumentos formales de ética normativa por parte de las revistas del Índice de Conacyt, se encontró que 43 publicaciones, han creado pequeñas notas o señalamientos éticos. Estos pueden conceptualizarse como acotaciones sobre los deberes morales de editores, autores y revisores que no forman parte de un texto independiente y en extenso. Los documentos más comunes que acompañan a las notas o señalamientos éticos, en las publicaciones que los incluyen, son: Carta de Originalidad, Carta de Cesión de Derechos Patrimoniales y Declaratoria de Autoría Individual o Colectiva. 
La mayor parte de los instrumentos de ética empleados en la muestra de revistas analizada no contempla ninguna sanción a los revisores y autores que presenten mala conducta ética en el proceso de arbitraje y en las políticas de derechos de autor. En los casos es que se presentan sanciones, éstas recaen sobre los autores, circunscribiéndose a la negativa en la publicación del artículo científico o en el señalamiento en la web de la revista, de que su autor ha incurrido en plagio. Estas acciones se alinean con la práctica reciente de ejemplificar fallos éticos históricos en la investigación a fin de orientar a los científicos para que los eviten. Tal situación acontece porque como afirman Koepsell y Ruiz de Chávez (2015, 29):

Entender cómo los científicos podrían llegar a cometer estas violaciones a la ética, con el fin de evitarlo, ha demostrado tener mayor efectividad que la imposición de sanciones. El actual régimen de supervisión y regulación es gravoso y a menudo es criticado por el papeleo extra y el proceso burocrático; sin embargo cada año salen a la luz nuevas violaciones éticas a la integridad académica y científica. El resultado global de cada uno de estos casos es la pérdida o debilitamiento de la confianza pública que en ocasiones tiene repercusiones reales como recortes presupuestarios y, en el peor de los casos, retrocesos a la ciencia en general.

De los 26 instrumentos de ética normativa localizados como parte de la política editorial de las Revistas Mexicanas de Investigación Científica y Tecnológica de CONACYT, ocho se derivan o complementan con la normativa de las entidades internacionales representadas en la Figura 1, que aparece en la siguiente página. 


\section{Ética en las revistas científicas mexicanas...}

Figura 1. Entidades internacionales y sus normativas que influyen o complementan los instrumentos de ética normativa de las Revistas Mexicanas de Investigación Científica y Tecnológica de CONACYT.

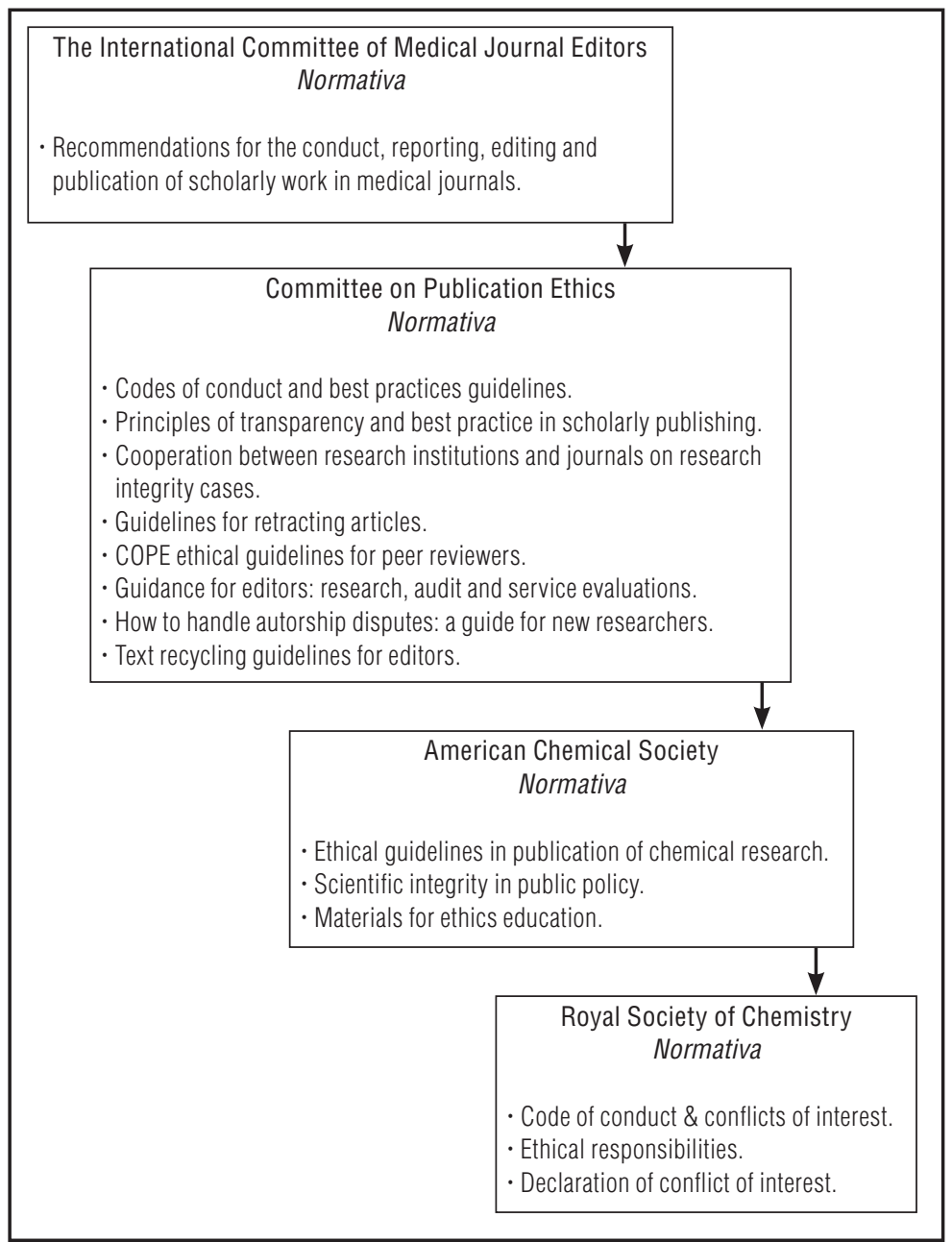

Fuente: Elaboración propia 


\section{Conclusiones}

Las revistas científicas mexicanas se encuentran en una fase prematura de inclusión de estándares e instrumentos de ética normativa por lo que los esfuerzos en este sentido tienen que potenciarse en el corto plazo. Lo anterior, con el objetivo de incrementar su calidad e ir en consonancia con las pautas internacionales sobre comunicación científica y difusión de los resultados de investigación. Al estudiarse los aspectos éticos de las publicaciones del Índice de Revistas Mexicanas de Investigación Científica y Tecnológica en los procesos de arbitraje y las políticas de autor se encontraron notables vacíos que derivan de una política editorial poco clara que no específica deberes y obligaciones de editores, revisores y autores. La transparencia es un valor que ha de permear todos y cada uno de los procesos editoriales de una revista científica y alcanzar a los actores involucrados. Los editores no pueden ser negligentes y esperar que sus colaboradores diluciden con qué pautas de comportamiento han de conducirse puesto que la práctica científica en las distintas disciplinas tiene características particulares. Un trabajo posterior, enfocado en el conocimiento que los editores de las revistas del Índice poseen con relación a los procesos de arbitraje y las políticas de derechos de autor, contribuiría al entendimiento sobre cómo encauzarlos, formalizarlos e instituirlos mediante códigos de ética, directrices de ética y malas prácticas en las publicaciones científicas.

\section{BiBLIOGRAFÍA}

Baiget, T. (2010). "Ética en revistas científicas". Ibersid: revista de sistemas de información y documentación 4, 59-65.

Bravo Toledo, R. (2008). Aspectos éticos en las publicaciones cientificas. Disponible en: $<$ http://www.infodoctor. org/rafabravo/fraude.htm>. 
Camps, V, O. Guariglia y F. Salmerón. (2004). Concepciones de la ética. Madrid: Editorial Trotta/Consejo Superior de Investigaciones Científicas.

Castillo Bautista, R. Ética del Desarrollo. Disponible en: $<$ http://www.eumed.net/cursos/rcb-ed/5.htm>.

Code of Conduct and Best Practice Guidelines for Journal Editors. (2011). London: COPE Council.

Colombet, C. 1997. Grandes principios del derecho de autor y los derechos conexos en el mundo. Estudio de derecho comparado. Madrid: UNESCO/CINDOC.

Corbetta, P. (2007). Metodología y técnicas de investigación social. Madrid: Mc Graw Hill.

Cortina, A. y E. Martínez. (2008). Ética. Madrid: Akal.

Coslado, M.A., I. Lacunza y G. Ros. (2011). "Evaluación de la calidad de revistas científicas españolas: análisis de sus procesos de revisión". El profesional de la información vol. 20, núm. 2, 159-164.

Delgado-López-Cózar, E., D. Torres-Salinas y A. RoldánLópez (2007). "El fraude en la ciencia: reflexiones a partir del caso Hwang". El profesional de la información vol. 20, núm. 2, 159-164. Disponible en: < https:// doi.org/10.3145/epi.2007.mar.07>.

Flick, U. (2015). El diseño de investigación cualitativa. Madrid: Morata. 
Hames, I. (2012). "Peer Review in a Rapidly Evolving Publishing Landscape". En Academic and Profesional Publishing, editado por Robert Campbell, Ed Pentz e Ian Borthwick, 15-52. Cambridge: Chandos Publishing.

Internet Encyclopedia of Philosophy. (2016). Martin: IEP. Disponible en: <http://www.iep.utm.edu/ethics/> [Fecha de consulta: 12 de mayo de 2016].

Koepsell, D.R. y M.H. Ruiz de Chávez. (2015). Ética de la Investigación. Integridad Científica. México: Comisión Nacional de Bioética/Secretaría de Salud.

Lozano Aguilar, J.F. (2007). "Códigos éticos y auditorías éticas". Veritas: Revista de filosofía y teología, vol. 17, 225-251.

Melero, R. y M.F. Abad García. (2008). "Revistas open access: características, modelos económicos y tendencias". BiD: Textos universitaris de biblioteconomia i documentació vol. 20. Disponible en: <http://bid.ub.edu/ 20meler2.htm>.

Merton, R.K. (1942). "Note on Science and Democracy". Legal \& Pol. Soc. vol. 1, p. 115.

Mora-Campos, A. (2015). "Nuevas formas de revisión por pares en revistas científicas: revisión abierta/open review/open review". Pensar en Movimiento: Revista de Ciencias del Ejercicio y la Salud vol. 13, núm. 1, 1-4.

Nassi-Caló, L. (2015). "Revisión por pares: modalidades, pros y contras". SciELO en Perspectiva (blog), 27 de marzo. Disponible en: <http://blog.scielo.org/es/2015/ 03/27/revision-por-pares-modalidades-pros-y-contras/ \#.V2CWwrvhCuk 
Rodríguez Sánchez, Y., M.E. Mesa Fleitas y E. Álvarez Solórzano. (2006). "La ética del profesional de la información ante la nueva sociedad del conocimiento". Acimed vol. $14,1$.

Ruiz-Pérez, R. (2008). Calidad editorial: instrucciones a autores y protocolos. Ponencia presentada en las "Jornadas de difusión de los resultados de la primera evaluación voluntaria de la calidad de las revistas científicas españolas".

Russell, B. (1972). Fundamentos de filosofía. Barcelona: Plaza \& Janés.

Silva Ayçaguer, L.C. (2011). "El arbitraje de las revistas médicas, la gestión editorial en red y la calidad de la publicación científica". Acimed, vol. 22, 2.

Sitio web de El Colegio de México. Principios éticos. Pronunciamientos de El Colegio de México. Disponible en: <http://www.colmex.mx/index.php?option=com content\&view $=$ article $\& i d=164 \&$ Itemid $=124>$ [Fecha de consulta: 20 de mayo de 2016].

Sitio web de la American Chemistry Society. ACS Committee on Ethics. Disponible en: <https://www.acs.org/ content/acs/en/about/governance/committees/ethics. html?_ga=1.134267889.1403622435.1466613917> [Fecha de consulta: 20 de mayo de 2016].

Sitio web de la Red de Investigación Educativa (Universidad del Cauca Colombia). El Derecho de Autor en la Era Digital. Disponible en: <http://www.iered.org/miembros/ ulises/representacion-ideas/Derechos-utor/derechos_ morales_y_patrimoniales_en_el_derecho_de_autor. html> [Fecha de consulta: 24 de abril de 2016]. 
Sitio web de la Royal Society of Chemistry. Policy $\&$ ethical guidelines. Disponible en: <http://www.rsc.org/ journals-books-databases/book-authors/policy-ethical -guidelines/\# ethical-policy> [Fecha de consulta: 14 de mayo de 2016].

Sitio web del Committee on Publication Ethics (COPE). Guidelines. Disponible en: <http://publicationethics. org/resources/guidelines $>$ [Fecha de consulta: 14 de mayo de 2016].

Sitio web del Consejo Nacional de Ciencia y Tecnología de México. Índice de Revistas Mexicanas de Investigación Científica y Tecnológica. Disponible en: <http:// www.conacyt.mx/index.php/comunicacion/indice-derevistas-mexicanas-de-investigacion $>$ [Fecha de consulta: 10 de marzo de 2016].

Sitio web del International Committee of Medical Journal Editors. Recommendations for the Conduct, Reporting, Editing, and Publication of Scholarly Work in Medical Journals. Disponible en: <http://www.icmje.org/ recommendations/ $>$ [Fecha de consulta: 12 de mayo de 2016].

Seely, M. y L. Wasoff. (2012). "Legal Aspects and Copyright". En Academic and Profesional Publishing, editado por Robert Campbell, Ed Pentz e Ian Borthwick, 355-383. Cambridge: Chandos Publishing.

Spinak, E. (2015) "Ética editorial: los arbitrajes fraudulentos". SciELO en Perspectiva (blog), 20 de febrero. Disponible en: <http://blog.scielo.org/es/2015/02/20/eticaeditorial-los-arbitrajes-fraudulentos/\#.V2Htvrvhcuk>. 
Ética en las revistas científicas mexicanas...

Tur-Viñes, V., M.C. Fonseca-Mora y B. Gutiérrez-San-Miguel. (2012). "Ética de la publicación científica: iniciativas y recomendaciones". El profesional de la información vol. 21, núm. 5, 491-497.

White Paper on Publication Ethics. (2012). Wheat Ridge: Council of Science Editors. 


\title{
Las bibliotecas universitarias ante los Cursos Masivos Abiertos en línea (MOOCs): Análisis de una relación por consolidar
}

\author{
Pedro RAZQuin ZaZPe \\ Universidad Complutense de Madrid, España
}

\section{INTRODUCCIÓN}

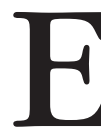

n la última década, muchas universidades de todo el mundo han comenzado a ofrecer Cursos masivos abiertos en línea (más conocidos como MOOC), junto a su oferta formativa tradicional. Pese a lo reciente del fenómeno y a la falta de estudios concluyentes sobre el impacto real de estos cursos en la educación superior, parece admitido que este hecho supone importantes cambios en la práctica docente y el modelo de negocio de las instituciones.

De acuerdo con Wu (2013) "si los MOOC van a transformar la Educación Superior, esto tendrá indudablemente un impacto significativo en la forma en que las bibliotecas trabajan y en el rol que desempeñan en el futuro del aprendizaje". Aceptado este hecho como premisa básica, en este trabajo se analizarán las posibilidades de colaboración entre las bibliotecas universitarias y los creadores de estos cursos, así como las implicaciones que esta nueva forma de aprendizaje tiene para los profesionales de la información.

La situación actual de los estudios en el campo de la cooperación biblotecas-MOOC, según Barnes (2013), se caracteriza por la existencia de pocos estudios, debido a lo reciente del fenómeno; 
los trabajos existentes están centrados principalmente en el escenario de Estados Unidos y, en muchos casos, no tienen en cuenta las características propias de otros sistemas educativos; además el debate abierto se lleva a cabo en la blogoesfera y no tanto en ámbitos académicos más tradicionales, como las revistas científicas.

Al mismo tiempo, es evidente que se trata de un tema que suscita gran interés en el mundo profesional, como se puede comprobar por la celebración de eventos tales como MOOCs and Libraries: Massive Opportunity or Overwhelming Challenge? (OCLC, 2013), MOOCs: Opportunities and Challenges for Libraries (IFLA World Library and Information Congress, 2014) o, en el ámbito español, las XIII Jornadas CRAI: MOOC y CRAI: Aprendizaje Virtual, organizadas por Red de Bibliotecas Universitarias (REBIUN, 2015).

Para llevar a cabo este estudio se analizarán los distintos agentes participantes, así como sus relaciones que, en algunos casos, resultan complejas. Los principales elementos a considerar en este escenario son: el Curso Masivo (MOOC) ofertado por la universidad, la Biblioteca universitaria (convertida en Centro de Recursos para el Aprendizaje y la Investigación CRAI), y la comunidad universitaria, formada esencialmente por estudiantes y profesores desarrolladores, que participa en los cursos y requiere de nuevos servicios de apoyo.

\section{Cursos Masivos Abiertos en Línea (MOOC)}

Desde el año 2008, con la impartición del curso Connectivism and Connective Knowledge (CCKO8), organizado por Stephen Downes y George Siemens en la Universidad de Manitoba (Canadá), una nueva práctica educativa: los cursos masivos en línea (MOOC) se abren paso en el panorama internacional de la Educación Superior. Este popular acrónimo se corresponde, inicialmente, con Cursos (es decir, contenidos de aprendizaje estructurados) Masivos (con decenas o centenares de estudiantes inscritos) Abiertos (en el sentido de gratuitos y sin requisitos previos) en Línea (suministrados a través de Internet). 
A partir del 2012, con el respaldo de algunas de las universidades americanas de élite (Stanford, Harvard y Massachusetts Institute of Technology MIT, especialmente) esta práctica docente se extiende rápidamente en el escenario de la formación universitaria. Con la aparición de las plataformas MOOC (Coursera, Udacity y edx, principalmente) los MOOC son suministrados a través de empresas, de distinta índole, que ofrecen una infraestructura tecnológica que permite la gestión, alojamiento y difusión de los cursos de una manera centralizada (aunque no exclusiva). Las universidades que secundan este tipo de iniciativas así como los cursos que se ofrecen se cuentan ya por decenas, y los estudiantes potencialmente interesados por miles. En el caso de Coursera, por ejemplo, se trata de más de 30 universidades y 15 millones de usuarios registrados, según datos de septiembre de 2015.

Se presencia lo que se ha denominado el fenómeno MOOC. Este hecho ha sido acogido con expresiones tales como "la revolución de la educación universitaria, el fin de la universidad tal y como hoy la conocemos" (Harden, 2012), "los mejores cursos de los mejores profesores en las mejores universidades, gratis para todos los que tengan una conexión a Internet" (Koller, 2012). Incluso previsiones de futuro como la aseveración de Sebastian Thrun de Udacity: "En 50 años habrá sólo 10 instituciones en el mundo que proporcionen Educación Superior y Udacity tiene la oportunidad de ser una de ellas" Si se aplica el Modelo de Ciclo de sobreexpectación de Gartner a esta situación se podría afirmar que se sitúa en la fase 2: Pico de expectativas sobredimensionadas, común a la evolución de cualquier innovación o desarrollo tecnológico.

De hecho, los estudios posteriores de los MOOC ponen en entredicho a algunas de estas grandes expectativas. Por ejemplo, las bajas tasas de finalización de los cursos, en muchos casos inferiores al 10\%, nos obligan a repensar las dimensiones reales de su impacto; el alto porcentaje de estudiantes en los MOOC con formación universitaria previa nos hacen replantearnos la idea de que estos cursos democratizan la educación superior poniéndola al alcance de estudiantes que no tienen acceso a ella; el hecho de que "en lugar de la educación para todos, los MOOC ahora prometen la 
educación para la empleabilidad" (Watters, 2015), permiten dudar de que estos cursos vayan a reemplazar la educación universitaria tradicional, asociada a la formación humanística, el pensamiento crítico y el desarrollo de la investigación, sino más bien a complementarla.

En cualquier caso, conviene no olvidar que estamos ante un escenario con una trayectoria temporal corta y en plena evolución. Incluso la conceptualización misma del término MOOC es dudosa, como acertadamente se indica: "cada uno de sus componente es negociable” (Plourde 2013). Por esta razón un acercamiento a las distintas tipologías de cursos MOOC resulta de gran utilidad, ya que las posibilidades de participación de los bibliotecarios en ellos dependen en gran parte del enfoque pedagógico del curso.

La clasificación de los MOOC más extendida (Downes, 2012; Siemens, 2102; SCOPEO, 2013) los divide en dos tipos básicos: CMOOC y XMOOC. LOS CMOOC O MOOC conectivistas, se corresponden con los MOOC originales, son conocidos también como MOOC de la primera generación. Adoptan el enfoque conectivista de la educación propuesto por George Siemens (2005) como respuesta al entorno digital de aprendizaje. Los cursos que siguen este novedoso planteamiento pedagógico se caracterizan (Fini, 2009; Rodriguez, 2012) por estar dirigidos por el estudiante (student-driven), ser caóticos y con un final abierto (open-ended) y además se han publicado bajo licencias abiertas de manera que sus contenidos pudieran ser remezclados y reutilizados (Downes, 2012). Este tipo de curso requiere del estudiante un alto grado de destrezas informáticas y de alfabetismo informacional y en segundo lugar, los estudiantes generan sus propios y nuevos contenidos, por lo que las posibilidades de intervención de las bibliotecas son variadas: desde la formación en destrezas informacionales a la recopilación y gestión de los contenidos generados.

El segundo tipo, los XMOOC se centran en la transmisión de los contenidos. Desde un punto de vista pedagógico podemos decir que adoptan un enfoque instructivista. En estos cursos los profesores establecen los objetivos pedagógicos, proporcionan los recursos de aprendizaje y fijan el sistema de evaluación. 
Muchos de los MOOC ofertados por las principales plataformas, como Coursera, Udacity o Miriadax, son esta clase. El curso se estructura habitualmente en segmentos de vídeo (de entre 5 y 10 minutos de duración), que el estudiante debe ver antes de completar los ejercicios. Aquí la participación y el feedback del instructor están minimizados y la evaluación del progreso del estudiante se hace mediante cuestionarios de corrección automática y, en alguno casos, mediante la evaluación entre pares. En palabras de Cabero (2014) estos MOOC "tienden a ser cursos universitarios tradicionales de e-learning que se adaptan a las características de las plataformas de los MOOC”. LOS XMOOC son, en esencia, cursos cerrados; podríamos decir que son autocontenidos, en el sentido de que todos los materiales de aprendizaje son creados, seleccionados y distribuidos por el profesor dentro del entorno, y, por tanto, la necesidad de los estudiantes de acudir a los servicios de la biblioteca es mínima.

Posteriormente, Lane (2013) aporta una tercera categoría al panorama: los MOOC basados en tareas. En este tipo de cursos se enfatizan las habilidades o competencias del estudiante, al que se le pide completar unas determinados tareas para ir progresando a través de la secuencia de aprendizaje. La pedagogía de estos MOOC tiende a ser una mezcla de instructivismo y constructivismo. Algunos autores se han referido a este tercer tipo como modelo bíbrido o tMOOC.

Aunque existen otros trabajos de clasificación posteriores, como los ocho tipos de Clark (2013), consideramos que se trata de subclases o variaciones de los tipos principales ya mencionados y que tienen poco interés para nuestro anális. Sin embargo, entre los nuevos formatos de cursos que van surgiendo, es importante destacar uno de los más recientes: los SPOC (Small Private Online Course). Se trata de MOOC locales, con un grupo de estudiantes restringido que, en algunos casos, se desarrollan en un entorno de aprendizaje mixto (b-learning). Según los primeros análisis esta modalidad tiene muchas posibilidades de éxito y permitiría más fácilmente la colaboración de la biblioteca dado que el número de estudiantes es reducido. 
A modo de resumen de esta situación, se usarán las palabras de Zapata Ros (2014) que afirma "Los MOOC han venido para quedarse. Pero la modalidad definitiva seguramente tendrá muy poco parecido con la actual. Y lo que es seguro es que no se llamará así”.

\section{De la Biblioteca Universitaria al Centro de Recursos para el Aprendizaje y la Docencia (CRAI)}

En las últimas décadas, las bibliotecas universitarias han sido objeto de importantes cambios. Aunque las razones para esta transformación son múltiples, de forma resumida, habría que destacar, en primer lugar, la irrupción de variadas innovaciones tecnológicas, que podríamos englobar bajo la etiqueta genérica de proceso de digitalización y que afecta a la naturaleza de los fondos custodiados en ellas, a las formas de trabajo y a los servicios ofrecidos. En segundo lugar, los importantes cambios producidos en la práctica docente de las instituciones en las que las bibliotecas universitarias están inmersas. Este nuevo enfoque de la enseñanza en la educación superior está caracterizado por un cambio de eje: de enseñar a aprender (el estudiante es el centro del proceso), el uso masivo de los Sistemas de Gestión de Aprendizaje (LMS) y la aplicación de estrategias de aprendizaje mixto (b-learning), que combinan las clases presenciales y virtuales. En tercer lugar, la aparición de un nuevo tipo de estudiante/usuario, popularmente conocido como nativo digital, cuyas formas de estudiar, aprender y relacionarse son nuevas y que demandan (y esperan) unos servicios distintos de la biblioteca.

Desde una perspectiva clásica, y según el $A L A$ Glossary of $L i$ brary and Information Science (citado en Martín Gavilán, 2008), la biblioteca universitaria es entendida como "una biblioteca (o sistema de éstas) establecida, mantenida y administrada por una universidad, para cubrir las necesidades de información de sus estudiantes y apoyar sus programas educativos, de investigación y demás servicios". En los últimos años, el papel clásico de la biblioteca se ha desarrollado en las siguientes áreas (Campbell 2006): 
- Proporcionando espacios de aprendizaje de calidad. La biblioteca ha pasado de ser un almacén de libros a convertirse en un espacio para la cooperación y la comunicación pero no sólo para los estudiantes.

- Ofreciendo servicios de referencia virtual. Gracias a las herramientas tecnológicas de comunicación el tradicional servicio de referencia se puede ofrecer ahora de manera más flexible, con independencia del horario y la ubicación, permitiendo por ejemplo una mejor colaboración en los proyectos de investigación adoptando el rol de bibliotecario incrustado o embedded librarian (Dewey, 2004).

- La enseñanza de la alfabetización informacional. La formación de usuarios, habitual en las bibliotecas, se ha convertido en alfabetización informacional. Las competencias en la búsqueda y gestión de la información son críticas en los entornos de aprendizaje actuales, mediatizados por la tecnología, y su enseñanza es una de las tareas fundamentales de la biblioteca. - La elección de los recursos y la gestión de las licencias de los recursos. La adquisición de recursos electrónicos, especialmente la suscripción a bases de datos y las revistas electrónicas, es una de las principales inversiones presupuestarias en las bibliotecas universitarias. Realizar una adecuada selección, que tenga en cuenta las necesidades de los usuarios y el uso efectivo que hacen de estos recursos, así como negociar el tipo de licencia más adecuado en cada caso, se ha convertido en una necesidad estratégica para todas las universidades.

- La creación de metadatos. La catalogación de los recursos digitales requiere del empleo de nuevas técnicas como la asignación de metadatos, pero además en algunos casos, la biblioteca pude verse necesitada de desarrollar sus propios esquemas o perfiles.

- La recolección y digitalización de los materiales de archivo. La digitalización de distintos tipos de materiales con el objetivo de mejorar su difusión y lograr una preservación a largo plazo se ha convertido en otra importante área de trabajo. 
- El mantenimiento de repositorios digitales. La creación y gestión de repositorios institucionales como una forma de publicación y difusión de la producción investigadora, en línea con el movimiento de Acceso Abierto a la información científica (OAI) es actualmente una de las tareas con mayor proyección e impacto. En algunos casos se complementa con la construcción de repositorios especializados en objeto de aprendizaje, cada vez más abundantes a partir del uso extendido de las plataformas de aprendizaje.

En este contexto actual, resulta muy esclarecedora la aportación de Serrat y Sunyer (2008), que nos detallan lo que los nuevos estudiantes, que denominan usuarios 2.0, esperan de la biblioteca:

- Servicio permanente (24 horas/ 7 días).

- Servicios digitales y servicios presenciales (espacios de estudio y trabajo en grupo).

- Contenidos específicos.

- Servicio personalizado (just for me).

- Respuesta rápida (just in time, at a click).

- Usable y atractiva.

- Ubicua y accesible (desde el despacho, desde casa, mediante dispositivos móviles).

- Confidencialidad.

\section{Evolución de biblioteca universitaria a CRAI}

Para adaptarse al entorno digital de enseñanza/aprendizaje, en el que se haya implicada la educación superior actual, muchas bibliotecas universitarias han creado sus propios Centros de Recursos para el Aprendizaje y la Investigación (CRAI) que les permitan asumir las nuevas funciones derivadas de esta situación. Estas estructuras son el equivalente a los Learning Resources Centres (LRC) existentes en el ámbito sajón y con una fuerte implantación, especialmente en el Reino Unido. La idea clave que subyace en este proceso de transformación es la convergencia de servicios y 
tiene como objetivos lograr una optimización de los recursos de la institución y ofrecer una mayor calidad en sus prestaciones con un menor coste económico. Aunque las áreas de la universidad implicadas son múltiples, es especialmente crítica la convergencia entre las bibliotecas y los servicios informáticos (Marshalsay, 1998; Hanson, 2005).

El CRAI se entiende, de acuerdo con Balagué (2003), como:

[...] un entorno dinámico en el que se integran los recursos que soportan al aprendizaje y la investigación en la universidad, donde convergen servicios y recursos diferentes: servicios informáticos, bibliotecarios, audiovisuales, de capacitación pedagógica y otros, en un marco espacial, con recursos materiales, humanos, de información y aprendizaje tendentes a la integración de objetivos y proyectos comunes.

Como se puede inferir a partir de la conceptualización previa, la implantación de los Centros de Recursos implicará cambios en la universidad, entre ellos destacamos los relativos a las modificaciones organizativas y a la adaptación de los espacios.

Modificaciones organizativas. Como afirma Area (2006) "los CRAI son principalmente un problema organizativo [...] por la convergencia e integración de diferentes servicios que coexisten de forma paralela a veces en muchas Universidades". Se trata de crear y organizar un equipo multidisciplinar, que agrupe a especialistas procedentes de distintas unidades o servicios, para trabajar con un objetivo estratégico común. Para lograrlo existen, según Pinto (2008), varias modalidades organizativas que podemos clasificar de acuerdo a tres modelos: El Modelo Burocrático, con una estructura altamente jerarquizada. Los servicios actúan de forma independiente, aunque están supervisados por un responsable que rinde cuentas a la dirección de la institución. El Modelo Funcional, está basado en el funcionamiento de equipos organizados en torno a un dominio y reagrupados en una estructura sectorial integrada de servicios. Y, en tercer lugar, el Modelo de participación voluntaria: con el objetivo de favorecer la cooperación entre 


\section{Uso ético de la información...}

los distintos servicios, en algunas universidades han optado por una gestión coordinada por un miembro del comité director de la institución, permitiendo así relaciones más dinámicas que los mecanismos habituales de responsabilidad unilateral

Una segunda clasificación, bastante similar a la anterior, establece los siguientes modelos: Modelo Supervisión politica y gerencial: el responsable es un vicerrector al que informan los responsables de las áreas o unidades, y la prestación de servicios es separada. Modelo de Coordinación estratégica, el responsable es un vicerrector que coordina activamente a las distintas unidades, que mantienen su autonomía, pero trabajan en un marco estratégico común, con niveles importantes de interdependencia y Modelo de Convergencia en la prestación de servicios, similar al anterior, pero con una mayor integración de servicios, que pueden implicar la redefinición de las funciones y perfiles de los profesionales implicados (Cabo y Espinós, 2005).

Desde el punto de vista de la prestación de servicios los CRAI pueden estar organizados de tres formas principales: Centraliza$d o$, todos los servicios en un solo espacio físico. Descentralizado, con las siguientes opciones: varios CRAI ubicados en cada uno de los campus de la institución o, pese a contar con una unificación institucional, se da una diversificación de los servicios ofertados en distintos centros. Híbrido o mixto: es basado en la propuesta de un solo CRAI, pero con servicios descentralizados (Zamora, 2012; Area, 2006).

En cualquier caso, no existe un modelo único o más adecuado para todas las instituciones, sino que se debe contemplar la especificidad de cada universidad. Por ejemplo, para las universidades pequeñas o de reciente creación, y ubicadas en un solo campus, un CRAI único centralizado es la opción más adecuada. Pero para aquellas universidades grandes, dispersas en varios campus o con múltiples edificios, y con cierta trayectoria histórica e independencia de los servicios convergentes, probablemente un modelo descentralizado, o, en todo caso, híbrido será la opción más viable.

Aunque a veces se infravalora la importancia de la adaptación del espacio físico y la transformación de los espacios de la nueva 
biblioteca, éste es un punto crítico en el éxito del proceso de adaptación a las nuevas necesidades. La creciente preponderancia de los servicios relacionados con el aprendizaje, la docencia y la socialización de la comunidad universitaria necesita un adecuado entorno físico. Como indica McDonald (2005: 2):

[...] los nuevos centros de recursos para el aprendizaje ofrecen una variedad cada vez mayor de espacios para el aprendizaje informal, el trabajo en grupo, el aprendizaje conjunto, la preparación de trabajos, el uso del ordenador portátil y la formación de usuarios, y, a menudo, disponen de cafetería.

De hecho, de acuerdo con las recomendaciones de IFLA, Latimer (2010) afirma muy expresivamente:

Los mayores cambios se han producido en el diseño y el equipamiento de los espacios de aprendizaje, gracias a las redes inalámbricas y la zonificación. Donde una vez hubo apretadas filas de asientos con un pequeño número de cubículos privados y un muy pequeño número de habitaciones disponibles para la reserva, las bibliotecas ofrecen ahora una amplia gama de espacios de estudio y aspiran a diseños más informales y aleatorios que permitan las permutaciones de los espacios.

Los CRAI en España. Muchas de las principales universidades españolas cuentan ya con Centros de Recursos, aunque el panorama presenta distintos grados de implantación, con diferentes estructuras organizativa y significativas variaciones en la oferta de servicios. En el ámbito educativo, el desarrollo de estas iniciativas responde, en gran medida, a la necesidad de adaptación al Espacio Europeo de Educación Superior (EEES), puesto en marcha en el año 2000, y al consecuente cambio del modelo docente centrado en el trabajo personal del estudiante y no tanto en la asistencia a clases presenciales, plasmado en el sistema de créditos ECTS.

La importancia que se le concede a este desarrollo se refleja en el II Plan Estratégico (2007-2010) de REBIUN cuyo primer objetivo 
estratégico es "[...] continuar potenciando el nuevo modelo de biblioteca universitaria como Centro de Recursos para el Aprendizaje y la Investigación CRAI".

En este escenario el CRAI de la Universidad de Barcelona, una de las instituciones pioneras en este cambio, puede servir como paradigma al ofrecer los siguientes servicios (Martínez, 2004):

- Servicio de información global y acogida de la universidad.

- Servicio de biblioteca.

- Servicio informático para los estudiantes.

- Servicio de laboratorio de idiomas.

- Servicio de búsqueda activa de empleo.

- Servicio de salas de estudio y aulas de reserva (espacios de trabajo).

- Servicio de soporte a la formación del profesor.

- Servicio de creación y elaboración de materiales docentes y multimedia.

- Servicio de presentaciones y debates.

- Servicio de soporte a la formación del profesor.

- Servicio de creación y elaboración de materiales docentes y multimedia.

- Servicio de presentaciones y debates.

A modo de conclusión de este apartado, hay que decir que la adopción y éxito del modelo CRAI depende en gran medida a las características propias de cada universidad. En el caso concreto de las universidades públicas españolas hay que destacar que la importante inversión económica que supone esta transformación no cuenta, actualmente, con las oportunidades de financiación más adecuadas, por lo que las posibilidades de implantación real están negativamente condicionadas. Además se requiere una política institucional, que en muchos casos estará condicionada por la propia historia y trayectoria de la universidad, que sea capaz de lograr la implicación del equipo humano, el otro elemento crítico en este proceso. Conviene contemplar que se pueden presentar fuertes resistencias al cambio de funciones y a las nuevas maneras 
de trabajar que impidan un eficaz funcionamiento de los CRAI. Finalmente, hay que constatar que el grado de desarrollo así como la calidad y variedad de los servicios ofertados por los Centros de Recursos determinará las posibilidades de cooperación entre la biblioteca y los MOOC, que es el objetivo principal de este estudio.

\section{Usuarios DEL MOOC: EsTUdiANTES Y PROFESORES}

Aunque lógicamente toda la comunidad universitaria, en mayor o menor medida, se haya implicada en la impartición de los MOOC, aquí nos centraremos en dos de sus agentes: los estudiantes, como destinatarios últimos del curso, y los profesores desarrolladores, como responsables directos de su puesta en marcha.

Los estudiantes del siglo XXI. Las jóvenes generaciones de estudiantes, conocidos como nativos digitales (Prensky, 2001) y por otros autores como generación Google o net generation (Gunter, Rowlands y Nicholas, 2009) poseen unas características que las diferencian de los estudiantes anteriores. Los rasgos principales de este tipo de estudiante, según los estudios de Prensky (2001), son: jóvenes, activos, poseen destrezas informática (porque han crecido con un ordenador en sus manos), demandan inmediatez y rapidez en la interacción con el profesor, requieren bloques de información pequeños, esperan contenidos de aprendizaje en formato multimedia (no sólo texto) y cuentan con una alta conectividad y disponibilidad fuera de horarios rígidos.

Pero, además, entre sus carencias o dificultades para el aprendizaje destacan: No saben identificar lo relevante y fiable (Rowlands y Williams, 2007), un gran número de estudiantes no sabe cómo usar estrategias refinadas de búsqueda, manejo y evaluación de la información (Cabra y Marciales, 2009), carecen de espíritu crítico, son impacientes y con déficit de atención y no respetan la propiedad intelectual, aspecto de enorme trascendencia ética.

Por tanto conocer y tener presentes estas características de los estudiantes jóvenes, previsiblemente el grupo mayoritario en 
la educación superior, es crítico para poder apoyarles de manera efectiva en su proceso de aprendizaje.

Los estudiantes en los MOOC. El comportamiento y tipología de los estudiantes que participan en los cursos masivos presenta unas características específicas. De modo sintetizado se señalaron las siguientes:

Alta tasa de abandono: Aunque las cifras varían de unos estudios a otros, por ejemplo, según Jordan (2014) sólo una media de $6.5 \%$ completan el curso, este hecho está suficientemente contrastado y se considera uno de los principales indicadores del éxito o fracaso de los MOOC. Este abandono puede depender de factores variados: la gratuidad de la oferta, la falta de una tutorización adecuada, el contenido mismo del curso o su diseño instruccional, entre otros, que todavía deben estudiarse en profundidad. En cualquier caso, muestran un bajo compromiso con el aprendizaje. Sin embargo, tiene un aspecto positivo, de cara al posible apoyo por parte de la biblioteca, el número de estudiantes implicados realmente es menor del inicialmente previsto y pueden por tanto ser mejor o más fácilmente asumidos por los servicios bibliotecarios.

Alto grado de formación previa: En los MOOC, actualmente, se da un predominio de los estudiantes con estudios superiores. Por ejemplo, según los datos de Koller y Ng (2013) en Coursera, el 42.8\% son licenciados, el $36.7 \%$ tiene un máster y un $5.4 \%$ tienen grado de doctor. $\mathrm{O}$, en el caso concreto de la Universidad de Pennsylvania, según los datos de Emanuel (2013), el 83,0\% son licenciados y un $44,2 \%$ tiene estudios a nivel de postgrado. Por tanto, los nativos digitales, vistos como jóvenes que se acercan por primera vez a la educación universitaria, no son actualmente un grupo mayoritario, aunque previsiblemente esto cambiará cuando se extienda el reconocimiento oficial de este tipo de cursos, o pasen a formar parte de las enseñanzas regladas.

Presentan motivaciones o intereses diversos. Las motivaciones de los estudiantes para inscribirse en los MOOC son variadas. Abarcan la simple curiosidad, la mejora profesional, el interés personal en la actualización de conocimientos o la necesidad de obtener un certificación de sus estudios, entre otras razones. 
Existe, por tanto, un grupo muy heterogéneo, mucho más que el habitual en la enseñanza presencial. A esta circunstancia habría que añadir, además, su variada procedencia geográfica, con las diferencias culturales e idiomáticas que esto implica.

Según su comportamiento en el curso, se puede establecer una tipología específica de estudiantes MOOC. Según Hill (2013) se correspondería 5 arquetipos de estudiantes.

(Aunque este autor expresa muy claramente que se trata de patrones emergentes y que pueden combinarse en distintos momentos). Son los siguientes:

-Ausentes (No-shows). Constituyen la mayoría de los estudiantes dentro de los XMOOC, no participan, no van más allá de registrarse en el curso. (Antes denominados Lurks o Rondadores).

- Observadores. Estos estudiantes se registran, pueden leer el contenido o revisar algunas discusiones, pero no participan en ninguna forma de evaluación.

- Participantes pasivos. Estos estudiantes ven el curso como contenido consumir. Suelen ver algunos vídeos, hacer algunas pruebas o exámenes, pero tienden a no participar en las actividades o debates de la clase.

- Participantes activos. Estos son los estudiantes que inscriben en el curso la intención de participar plenamente. Hacen las distintas tareas asignadas, los exámenes y participan activamente en las discusiones de los foros.

- Visitantes (Drop-Ins). Este tipo de estudiantes no trata de completar todo el curso, aunque llegan a ser participantes activos parcial o totalmente en un tema concreto

El estudiante en un MOOC conectivista. Como se ha indicado anteriormente, la orientación pedagógica de los cursos condiciona la posible cooperación biblioteca-MOOC, pero también exigen del estudiante diferentes formas de participación. En un curso de enfoque conectivista, según afirman Kop, Fournier y Mak (2011) las principales actividades del estudiante son: 
Uso ético de la información...

- Agregar: Buscar y acceder a una variedad de recursos para leer, mirar, jugar [...]

- Remezclar: Dar a la información un nuevo formato: crear un blog, un post en un foro, configurar una cuenta de Delicious.

- Replantear: Se estimula la creación propia de contenidos

- Compartir: Publicar y difundir su trabajo con otros participantes para laogra un construcción colectiva del conocimiento.

Como se puede ver en este contexto, para tener éxito en un entorno MOOC se requiere de los estudiantes una alta alfabetización digital (Yuan y Powell, 2013). Aquí las oportunidades de intervención del bibliotecario son amplias, no sólo en la alfabetización informática e informacional, sino también en aquellos aspectos éticos implicados en la reutilización y difusión de información procedente de terceros. Igualmente, una vez finalizado el curso, habría oportunidades de intervención en la recopilación y preservación de los nuevos materiales generados.

Profesores desarrolladores de MOOC. Los profesores implicados en la creación de MOOC son un grupo reducido en relación con el total de profesores en ejercicio dentro las universidades. Se puede afirmar que este segmento corresponde fundamentalmente con los innovadores en el sentido dado al término en la Teoría de difusión de innovaciones de Rogres. Estos profesionales tienen una fuerte motivación personal para participar en estas iniciativas. De hecho, en muchos casos, no obtienen de su universidad ninguna compensación directa por estas actividades, ni una menor carga docente ni un incentivo económico.

Aunque todavía son necesarios estudios más extensos en este campo, el trabajo de Kolowich (2013) mediante una encuesta a 103 profesores, nos permite un primer acercamiento al perfil de estos docentes. Respecto a la importante carga de trabajo que supone: la medida de horas empleadas en la preparación de un MOOC es de 100 horas, además se le dedican 8 horas a la semana mientras el MOOC está abierto. También es necesario constatar que un 97\% ha elaborado vídeos originales. En contrapartida, el $73 \%$ tiene la propiedad intelectual de los materiales creados. Pero este esfuerzo 
tiene como consecuencia directa quitar tiempo a otras dedicaciones como la investigación o las reuniones, según reconocen el 55\% de los entrevistados.

En relación con los motivos que les han impulsado a crear los MOOC, la razón más citada (por el 71.8\%) fue el altruismo, un deseo de aumentar el acceso a la educación superior en todo el mundo. Aunque también hay en juego motivaciones profesionales, como aumentar su visibilidad, tanto entre colegas dentro de su disciplina (un 39\%) y con los medios de comunicación y el público en general (un 34\%). Significativamente la posibilidad de obtener ingresos sólo fue considerada por un 5,8\%. Es destacable también que sólo un 14,6\% lo hizo a petición de un superior.

Muchos de los servicios de un CRAI, especialmente durante el proceso de producción, pueden serles muy útiles a estos profesores. Por ejemplo, puede apoyarse en el soporte técnico para desarrollo de materiales multimedia, en la asesoría y orientación pedagógica sobre la enseñanza en línea o en la difusión de sus trabajos a través de las redes sociales o la propia web institucional.

\section{Posibilidades. Colaboración entre bibliotecas y MOOC}

De forma sintetizada se puede decir que, en la literatura científica actual, se plantean tres enfoques generales sobre la posibilidad de colaboración entre las bibliotecas y los MOOC.

Postura 1: Escéptica. Este punto de vista podría calificarse de negativo y estaría representado, entre otros autores, por Gremmels: "Los bibliotecarios simplemente no son necesarios" (Gremmels, 2013). Estos investigadores no están exentos de algunos argumentos sólidos si pensamos en un modelo de curso XMOOC autocontenido. Sin embargo, a priori, este enfoque parece derivarse de la falta de un conocimiento profundo del funcionamiento de los MOOC: su variada tipología y de las distintas áreas y momentos de posible cooperación y, quizá también, de una visión desactualizada de las funciones de la biblioteca universitaria. Entre sus razones más importantes está la constatación de que hay, 
al menos, dos características de los MOOC que hacen que sean difíciles de integrar en los servicios bibliotecarios tradicionales:

- Las dimensiones de los cursos, es decir, el número de estudiantes inscritos, exceden en mucho a las habituales en los cursos a distancia convencionales, y lógicamente se requeriría un equipo humano mucho más grande para atender a estos cientos o miles de usuarios adicionales.

- La distribución de los cursos a través de plataformas externas. "Desafortunadamente, debido a que los MOOC utilizan su propia plataforma para albergar el contenido del curso, el trabajo realizado por los bibliotecarios dentro del sistema de gestión de cursos propios de la universidad, tales como la incorporación de los planes de lecciones o de ofrecer un servicio de Haz una pregunta al bibliotecario, no serían fáciles de transferir a las plataformas MOOC externas"(Wright, 2013).

Al parecer, esta postura es demasiado extrema y se centra básicamente en las posibilidades de apoyar a los estudiantes, ignorando las oportunidades de cooperación en otros aspectos, por ejemplo, durante la producción del curso.

Postura 2. Continuista. Ha sido posible usar esta denominación para hacer referencia al escenario descrito por Creed-Dikiegou y Clark (2013): "[...] en su mayor parte, los bibliotecarios pueden esperar asumir funciones que son similares a las que se tienen en los cursos tradicionales". Si bien es cierto que dos de los servicios fundamentales que las bibliotecas pueden ofrecer a los MOOC: la gestión de los derechos de autor y la formación en alfabetismo informacional ya se venían desarrollando con anterioridad, no es disparatado pensar que esta actitud: hacer lo mismo de siempre es insuficiente para satisfacer de manera edicaz las necesidades específicas de los actores mooc que son nuevas.

Postura 3: Proactiva. La biblioteca universitaria puede y debe participar en el MOOC. Esta idea está presente en los trabajos de Mahraj (2012), Barnes (2013) y Stephens y Jones (2015), entre otros. De hecho "[...] las bibliotecas están perfectamente situadas 
para ofrecer el apoyo institucional y la infraestructura física que puede ayudar a que los estudiantes se involucren en los cursos en línea" (Gashurov y Kendrick, 2014).

Esta convergencia supone nuevos retos y desafíos (dos de los términos más repetidos en este contexto) para las bibliotecas y dará lugar a roles emergentes para los profesionales de la información, que, en ciertos casos, suponen una puesta en valor de su larga experiencia como formadores de usuarios y de sus conocimientos en tecnologías de la información. Se ha denominado a esta postura como proactiva en el sentido de que, en lugar de esperar a la demanda de unas determinadas prestaciones, la biblioteca será capaz de ofrecer posibilidades de cooperación en ciertos ámbitos que, en principio, no están directamente asociados con sus tareas más tradicionales.

Como marco de referencia general, hay que decir que esta colaboración se puede llevar a cabo en función de dos potenciales usuarios objetivos: los estudiantes y los desarrolladores/ creadores de MOOC. En segundo término, que esta intervención puede realizarse desde dos perspectivas, como un servicio externo al curso o como un servicio integrado dentro del MOOC, es decir, con el bibliotecario formando parte del equipo gestor de los cursos. En este caso adoptaría un perfil de bibliotecario incrustado, en el sentido de estar centrado en las necesidades de un grupo específico y proporcionarle servicios altamente personalizados. Y por último que las variadas posibilidades de cooperación planteadas por los distintos estudios pueden agruparse en tres grandes áreas temáticas.

- Servicios de formación.

- Servicios de asesoría y gestión de los derechos de autor.

- Servicios de gestión informativa y documental.

A continuación, se revisan con detalle las aportaciones de algunos de los autores más destacados. Según Mahraj (2012) las formas de colaboración más reseñables son: 
- Enseñar destrezas en alfabetismo informacional.

La formación en alfabetismo informacional es quizá la tarea más importante de una biblioteca universitaria entre sus servicios de apoyo a la docencia. Este alfabetismo, definido habitualmente como "[...] un conjunto de habilidades que requieren las personas para reconocer cuándo se necesita información y tener la capacidad de localizar, evaluar y utilizar eficazmente la información necesaria”, resulta imprescindible en los entornos de aprendizaje actuales. Esto permitirá paliar las carencias del estudiante nativo digital, mencionadas en otro apartado de este trabajo y resulta fundamental para el estudiante en entornos MOOC conectivistas, Su relevancia para el sistema universitario español, bajo el nombre de Programa ALFIN es reconocida como el segundo objetivo estratégico de REBIUN: "Potenciar y promover acciones para el desarrollo e implementación de las Habilidades en Información como competencias transversales en el nuevo modelo docente".

Previsiblemente, en esta confluencia con los MOOC, la biblioteca universitaria deberá actualizar los tutoriales y materiales usados en esta tarea formación en varios aspectos: incrementar el nivel y número de las competencias consideradas necesarias que han ido evolucionando y aumentando, diversificar las formas de suministro para adecuarlos mejor a audiencias masivas y heterogéneas y aplicar un diseño pedagógico en la elaboración de los materiales que sea apropiado para el aprendizaje online.

- Ayudar con la organización y gestión de la información. Esta línea de trabajo corresponde con la función más tradicional del profesional de la información y por ello, lógicamente, es compartida por todos los autores consultados. Esta tarea que, como en cualquier otro proyecto, es esencial puede realizarse en varias fases de la producción del MOOC. Durante la planificación y el diseño, la gestión de los contenidos de aprendizaje del curso conlleva tareas de selección, descripción y, a veces, adecuación a estándares, para garantizar su accesibilidad. Una vez finalizado el proceso de producción, la 
documentación del proceso en sí: equipo, fuentes y recursos utilizados, criterios aplicados, tecnología empleada, etc. que es muy provechosa para el desarrollo de otros MOOC de la misma institución. Durante su celebración, implica labores de almacenamiento y descripción de los contenidos generados por los propios participantes durante su desarrollo, de cara a su preservación y posible reutilización. Una vez impartido el curso, los datos de los resultados, como número y características de participantes, la tasa de finalización, opiniones, problemas detectados, etc., son imprescindibles para su evaluación y de máximo interés para la investigación en el ámbito de los cursos masivos.

- Recopilar recurso educativos abiertos (OER).

Se considera este trabajo como parte de la misión anterior, más general y es una función específica por su extraordinaria utilidad y por solventar eficazmente los problemas de derechos de autor, así como el beneficio económico que supone para el MOOC la reutilización de materiales ya existentes para ahorrar gastos de producción.

En la misma línea de una potencial cooperación, pero con mayor precisión, Barnes (2013) detalla las siguientes tareas de la biblioteca-CRAI:

- Certificación de derechos (Copyright clearance).

Este servicio es considerado, de forma unánime, como una de las ayudas esenciales que la biblioteca puede prestar (en muchas ocasiones ya lo está haciendo) a los MOOC. Dos factores hacen particularmente decisivo este trabajo, por un lado, el amplio número y la variedad de formatos y procedencias de los materiales de aprendizaje contenidos en los cursos y, en segundo lugar, el hecho de que estos contenidos se van a distribuir en un marco internacional, donde confluyen varias legislaciones distintas y puede que contrapuestas. Por tanto, esta es una tarea trascendente y también costosa, ya que puede suponer 380 horas de trabajo por curso (Proffit, 2013). En este 
caso, se puede afirmar que las bibliotecas poseían previamente estos conocimientos expertos y lo que se producido, en su confluencia con los MOOC, es una mayor proyección pública, una puesta en valor, de sus capacidades de servicio.

- Licenciar contenidos (Content licensing)

- Promover el uso de licencias abiertas

Las dos funciones anteriores también se pueden enmarcar dentro de la gestión de derechos de autor. De una parte está la asesoría sobre las diversas opciones disponibles para licenciar los contenidos propios, generados para el curso. El enfoque predominante en el contexto MOOC más tradicional se inclinaría por el uso de algún tipo de licencias abiertas. Además, en sintonía con la filosofía del Acceso Abierto a la Información, la biblioteca puede promover su uso, difundiendo sus posibilidades y beneficios entre los autores creadores de materiales de aprendizaje. Se adopta así una actitud proactiva que ciertos autores (Gore, 2014) amplían bajo el lema influir en el personal de la facultad, donde se incluiría también la toma de conciencia acerca de la necesidad de contar con profesionales de la información en el desarrollo de los cursos.

Por otro lado, hay que considerar el uso que se hace en los cursos masivos de recursos de carácter comercial, como las bases de datos, las revistas y los libros, y sus implicaciones legales y económicas. En este aspecto, algunas plataformas MOOC, como Coursera están firmando convenios con las principales editoriales y distribuidoras (como Oxford University Press, Macmillan o Wiley) para establecer formas específicas e innovadoras de uso de estos materiales. Entre estas nuevas formas están, por ejemplo, el permitir un acceso temporalmente limitado (sólo durante la duración del curso), posibilitar el acceso gratuito a resúmenes o capítulos sueltos de monografías comerciales y ofertar precios especiales o descuentos para la adquisición de libros (físicos y electrónicos) para los estudiantes inscritos en el curso, entre otras. Los bibliotecarios cuentan con la experiencia de gestión necesaria para llevar a 
cabo negociaciones con editoriales y lograr acuerdos de uso adaptados a los MOOC de su institución.

- Ayudar con la organización y gestión de la información.

- Ayudar para dar accesibilidad a los contenidos, incluidos los usuarios que usan tecnologías asistivas.

En este aspecto, que otros autores no han resaltado, es conveniente indicar que para muchas instituciones públicas es obligatorio garantizar la accesibilidad de su cursos. Por esto, y de acuerdo con las pautas de accesibilidad web, los contenidos de aprendizaje multimedia deben incluir subtítulos, versiones alternativas a la información textual (grabaciones de sonido o podcast) y otras técnicas que faciliten el estudio de las personas con discapacidad. La accesibilidad adquiere especial significación en el entorno MOOC dado el número y heterogeniedad de sus usuarios, y, por esta misma razón, sería muy aconsejable suministrar versiones multilingües de los materiales de aprendizaje.

- Proporcionar formación en alfabetismo informacional.

Por su parte, Stephens (2013) se centra no tanto en los servicios de la biblioteca sino los roles que puede desempeñar el bibliotecario como profesional en el MOOC son y entre ellos destaca:

- Aprendiz. La participación activa le da un conocimiento profundo del entorno de aprendizaje con el que debe colaborar y también le proporciona un modo de mejora de su capacitación profesional.

En este aspecto, Stephens coincide con Gore (2014) quien además sugiere que el bibliotecario debe inscribirse en, al menos, dos MOOC distintos: uno de un tema de su especialidad para poder comprender el diseño pedagógico que se utiliza en estos cursos y otro de un tema completamente desconocido para obtener una visión profunda de los sentimientos y necesidades de los estudiantes al matricularse en algo que desconocen. 
- Creador. Su tarea es desarrollar contenidos, especialmente relacionados con alfabetismo informacional, los derechos de autor y el uso ético de la información.

- Colaborador (Partner). Como parte del equipo, para solucionar problemas, compartir conocimiento experto en tecnología. Estos dos roles parten de la perspectiva de que el bibliotecario es parte integrante del equipo, aunque con distintos cometidos. En el caso del rol de colaborador, como parte del soporte técnico, presupone claramente unas capacidades profesionales de los bibliotecarios que, en nuestro contexto concreto, no están suficientemente reconocidas ni aprovechadas.

- Conector. Asume tareas como localizar, compartir información, curating, etc.

Este rol del bibliotecario, que puede ejercerse de forma externa o desde dentro del equipo, está relacionado con su desempeño básico como gestor de información. Resulta indicado subrayar aquí la posibilidad de realizar labores de difusión y promoción de los cursos, a través de diversos medios, como la web de la biblioteca, los foros profesionales y las redes sociales, para las que está bien capacitado.

\section{Conclusiones}

Las posibilidades de colaboración entre las bibliotecas universitarias y los MOOC son múltiples. Dado que se trata de un escenario en fase de consolidación, será su evolución final la que determine las formas de convergencia más viables y eficaces.

Actualmente, los factores esenciales que condicionan el desarrollo de este trabajo conjunto son: el enfoque pedagógico del curso, sus dimensiones: masivo o no y la infraestructura humana y técnica disponible en la institución concreta.

La participación de los profesionales de la información en los equipos de desarrollo de cursos masivos es considerada, cada vez más, como una buena práctica, que mejora la calidad de los resultados. Coincide con la potenciación de las funciones docentes de 
la biblioteca universitaria que se está produciendo en los entornos de enseñanza/aprendizaje actuales.

Para la bibliotecas universitarias y sus profesionales es aconsejable optar por una actitud proactiva, sin miedo a los retos que las innovaciones suponen, como estrategia para afrontar el fenómeno MOOC. En última instancia, al incluir nuevas funciones docentes y técnicas en su perfil profesional, a pesar del esfuerzo añadido que lógicamente representa, lo que se produce es una mayor valoración y proyección de su trabajo.

\section{BiBLIOGRAFÍA}

Area Moreira, M. (2006) Informe final de la Biblioteca Universitaria al Centro de Recursos para el Aprendizaje e Investigación. Elaboración de una guía sobre la organización y gestión de un CRAI en el contexto de las universidades españolas. España: Ministerio de Educación y Ciencia, Secretaría de Estado de Universidades e Investigación, Dirección General de Universidades.

Balagué Mola N. (2003). La biblioteca universitaria, centro de recursos para el aprendizaje y la investigación: una aproximación al estado de la cuestión en España. Disponibleen:<www.rebiun.org/documentos/Documents/ IJCRAI/ICRAI2003_BibliotecaUniversitaria_Ce: ntroderecursosparaaprendizaje_NBalagueMola.pdf>

Barnes, C. (2013). MOOCs: The Challenges for Academic Librarians. Recuperado: <www.tandfonline.com/doi/ pdf/10.1080/00048623.2013.821048>

Cabero Almenara, J., M. del C. Llorente Cejudo, y A.I. Vázquez Martínez. (2014). Las tipologías de Mooc: Su diseño e implicaciones educativas. Disponible en: <http:// digibug.ugr.es/bitstream/10481/31663/1/rev181ART1. pdf> 
Cabo i Rigol, M. y M. Espinós i Ferrer. (2005). "Els centres de recursos per a l'aprenentatge i la investigació (CRAI): obrint pas a noves aliances i oportunitats". $B i$ bliodoc: anuari de biblioteconomia, documentació $i$ informació, 15-29.

Cabra Torres, F, y G.P. Marciales Vivas. (2009). "Nativos digitales: ¿ocultamiento de factores generadores de fracaso escolar?" Revista iberoamericana de Educación. núm. 50, 113-130.

Campbell, J.D. (2006). "Changing a Cultural Icon: The Academic Library as a Virtual Destination ". EDUCAUSE Review, vol. 41, núm. 1, 16-31.

Clark, D. (2013). MOOCs: Taxonomy of 8 Types of MOOC. Disponible en: <donaldclarkplanb.blogspot.com.es/ 2013/04/moocs-taxonomy-of-8-types-of-mooc.html>

Creed-Dikeogu, G., y C. Clark. (2013). "Are You MOOC-ing Yet? A Review for Academic Libraries". CULS Proceedings 3: 9-13. Disponible en: <newprairiepress.org/ culsproceedings/vol3/iss1/5/>

Dewey, B. I. (2004). "The Embedded Librarian: Strategic Campus Collaborations". Resource Sharing \& Information Networks, 17: 1-2, 5-17. Disponible en: <www. tandfonline.com/doi/abs/10.1300/J121v17n01_02>

Downes, S. (2012). MOOCs Trend Towards Open Enrollment, Not Licensing. Disponible en: <www.downes.ca/ post/59470>

-__— (2012). The Rise of MOOCs. Disponible en: <http:// www.downes.ca/post/57911> 
Emanuel, E.J. (2013). "Online education: MOOCs Taken by Educated Few". Nature, vol. 503 núm. 342. Disponible en: <http://www.nature.com/nature/journal/v503/ n7476/full/503342a.html>

Fini, A. (2009). "The Technological Dimension of a Massive Open Online Course: The Case of the CCK08 Course Tools". The International Review of Research in Open and Distance Learning, vol. 10 núm. 5, 1-26. Disponible en: <www.irrodl.org/index.php/irrodl/ article/view/643/1410>

Frand, J., y R. Bellanti. (2000). "Collaborative Convergence: Merging Computing and Libraries Services at the Anderson Graduate School of Management at UCLA". Journal of Business \& Finance Librarianship, vol. 6, núm. 2, 3-26.

Gashurov, I. y C. Kendrick. (2014). "Can Libraries Save the MOOC?" Campus Technology, 11 de junio. Disponible en: <https://campustechnology.com/articles/2014/11/ 06/can-libraries-save-the-mooc.aspx $>$

Gore, H. (2014). "Massive Open Online Courses (MOOCs) and Their Impact on Academic Library Services: Exploring the Issues and Challenges". New Review of Academic Librarianship, vol. 20, 4-28. Disponible en: $<$ www.tandfonline.com/doi/full/10.1080/13614533. 2013.851609>

Gremmels, G.S. (2013). "Staffing Trends in College and University Libraries". Reference Services Review, vol. 41 núm. 2, 233-252. Disponible en: <www. emeraldinsight.com/doi/full/10.1108/00907321311326165> 
Gunter, B., I. Rowlands, y D. Nicholas. (2009). "The Google Generation: Are ICT Innovations Changing Information Seeking Behaviour?" Elsevier.

Hanson, T. (ed.). (2005). Managing Academic Support Services in Universities: The Convergence Experience. London: Facet.

Harden, N. (2012). The End of the University as We Know It. Disponible en: <www.the-american-interest.com/ 2012/12/11/the-end-of-the-university-as-we-know-it/>

Hill, P. (2013). "Some validation of MOOC student patterns graphic". e-Literate blog. Disponible en: <http:// mfeldstein.com/validation-mooc-student-patternsgraphic/>

IFLA World Library and Information Congress. (2014). MOOCs: Opportunities and Challenges for Libraries. Disponible en: <www.ifla.org/past-wlic/2014/ifla80/ node/312.html>

Jordan, K. (2014). "Initial Trends in Enrolment and Completion of Massive Open Online Courses." International Review of Research in Open and Distance Learning, vol. 15, núm. 1.

Koller, D. (2012). What We Are Learning from Online Education. Disponible en: <https://www.ted.com/talks/ daphne_koller_what_we_re_learning_from_online_ education/>

Koller, D., y A. Ng. (2013). The Online Revolution: Education for Everyone. Disponible en: <http://sites. nationalacademies.org/cs/groups/pgasite/documents/ webpage/pga_072888.pdf> 
Kolowich, S. (2013). "The Professors Who Make the MOOCs". The Chronicle of Higher Education, vol. 18.

Kop, R., H. Fournier, y J.S.F. Mak. (2011). "A pedagogy of abundance or a pedagogy to support human beings? Participant support on massive open online courses". The International Review Of Research In Open And Distributed Learning, vol. 12, núm. 7, 74-93.

Lane, L. (2012). Three Kinds of MOOCs. Disponible en: $<$ http://lisahistory.net/wordpress/2012/08/three-kinds -of-moocs/>

Latimer, K. (2010). "Redefining the Library: Current Trends in Library Design". Art Libraries Journal, vol. 35, núm. 1, 28-34.

Mahraj, K. (2012). "Using Information Expertise to Enhance Massive Open Online Courses." Public Services Quarterly, vol. 8, núm. 4, 359-368.

Marshalsay, B. (1998). "Convergence and Resurgence: The Integration of Academic Libraries and Computing Centres." Canadian Journal of Information and Library Science, vol. 23, núm. 4, 28-61.

Martín Gavilán, C. (2008). Temas de Biblioteconomía: Bibliotecas universitarias: concepto y función. Los Centros de Recursos para el Aprendizaje y la Investigación (CRAI). Disponible en: <eprints.rclis.org/14816/1/crai. pdf>

Martínez, D. (2004). El Centro de Recursos para el Aprendizaje CRAI: el nuevo modelo de biblioteca universitaria. Disponible en: <http://www.aab.es/pdfs/gtbu_bu _crai.pdf> 
McDonald, A. (2005). Creación de Centros de Recursos para el Aprendizaje. Madrid: CRUE.

OCLC. (2013). MOOCs and Libraries: Massive Opportunity or Overwhelming Challenge? Disponible en: <www. oclc.org/research/events/2013/03-18.html>

Pinto Molina, M., D. Sales, y P. Osorio. (2008). Biblioteca Universitaria, CRAI y Alfabetización informacional. Gijón: Trea.

Prensky, M. (2001). "Digital natives, digital immigrants." On the Horizon, vol. 9, núm. 5, 1-6. Disponible en: $<$ http://www.marcprensky.com/writing/Prensky\%20 -\%20Digital\%20Natives,\%20Digital\%20Immigrants\%20 -\%20Part1.pdf>

-—— (2011). Enseñar a nativos digitales. Madrid: SM. Disponible en: <innovacioneducativasm. aprenderapensar.net/files/2011/09/Ensenar_nativos_ digitales.pdf>

Proffitt, M. (2013). "MOOCs and Libraries: An Overview of the (Current) Landscape". MOOCs and Libraries: Massive Opportunity or Overwhelming Challenge? Disponible en: <oclc.org/research/events/2013/03-18.html>

REBIUN. (nd). II Plan Estratégico 2007-2010 REBIUN. Disponible en: <www.rebiun.org/documentos/Documents/ IIPE/II\%20Plan\%20Estrat\%C3\%A9gico.pdf>

(2015). XIII Jornadas CRAI. MOOCS y CRAIs: Aprendizaje Virtual. Disponible en: <www.rebiun.org/ documentos/Paginas/XIII-Jornadas-CRAI.aspx > 
Rodriguez, C.O. (2012). "MOOCs and the AI-Stanford like Courses: Two Successful and Distinct Course Formats for Massive Open Online Courses". European Journal of Open, Distance and E-Learning, vol. 15, núm. 2. Disponible en: www.eurodl.org/index.php? $\mathrm{p}=$ archives \&year $=2013 \&$ halfyear $=2 \&$ article $=516$

Williams, P. y I. Rowlands, I. (2007). Information Behaviour of the Researcher of The Future. A British Library and JISC Study (Joint Information Systems Comittee). (Work Package II).

SCOPEO. (2013). Scopeo Informe $N^{o} 2$. MOOC: Estado de la situación actual, posibilidades, retos y futuro. Disponible en: <scopeo.usal.es/wp-content/uploads/2013/06/ scopeoi002.pdf $>$

Serrat Brustenga, M. y S. Sunyer Lázaro. (2008). El Centro de Recursos para el Aprendizaje y la Investigación (CRAI) en permanente transformación: Servicios $y$ recursos para el nuevo usuario 2.0. Disponible en: $<$ upcommons.upc.edu/bitstream/handle/2117/2427/ serrat_sedic_ponencia.pdf $>$

Siemens, G. (2005). "Connectivism: A Learning Theory for the Digital Age". International Journal of Instructional Technology and Distance Learning, vol. 2, núm. 10, 2005.

(2012). MOOCs Are Really a Platform. Disponible en: $\quad<w w w . e l e a r n s p a c e . o r g / b l o g / 2012 / 07 / 25 /$ moocsare-really-a-platform/> 
Stephens, M., y K. Jones. (2013). Emerging Roles: Key Insights from Librarians in a Massive Open Online Course. Disponible en: <www.tandfonline.com/doi/ abs/10.1080/1533290X.2014.946353>

Watters, A. (2015). The Mooc Revolution That Wasn't. Disponible en: <http://kernelmag.dailydot.com/issuesections/headline-story/14046/mooc-revolution-uberfor-education/>

Wright, F. (2013). "What Do Librarians Need to Know about MOOCS?" D-Lib magazine, vol. 19, núm. 3/4. Disponible en: <www.dlib.org/dlib/march13/wright/ 03wright.html>

Wu, K. (2013). Academic Librarians in The Age of Moocs. Disponible en: <www.emeraldinsight.com/doi/abs/10. 1108/RSR-03-2013-0015>

Yuan, L. y S. Powell. (2013) MOoCs and Open Education: Implications for Higher Education. A White Paper. UK: Centre for Educational Technology, Interoperability and Standards. Disponible en: <http://publications. cetis.org.uk/wp-content/uploads/2013/03/MOOCsand-Open-Education.pdf>

Zamora Fonseca, R. (2012). "Criterios y fundamentos para la implementación de Centros de Recursos para el Aprendizaje y la Investigación”. Biblios, vol. 49. Disponible en: <www.redalyc.org/articulo.oa?id= 16126405003>

Zapata-Ros, M. (2014). Los MOOC en la crisis de la Educación Universitaria. Docencia, diseño y aprendizaje. Amazon. 


\title{
De la "ciudad de Dios" a Telépolis. Tres tiempos en el contexto histórico-cultural de la naturaleza archivística ${ }^{1}$
}

\author{
Agustín Vivas Moreno \\ Universidad de Extremadura, España
}

\section{INTRODUCCIÓN}

T a presente contribución parte de una idea en la que ya se ha hecho hincapié en otras ocasiones. ${ }^{2}$ Se entiende que los análisis de la temporalidad son especialmente útiles para la comprensión de la naturaleza del objeto que se estudia. Recuérdese que, como decía el axioma kantiano, el Ser histórico es ser en el tiempo (categoría a priori). En consecuencia, el tiempo es una variable esencial que integra la definición de la realidad histórica, en este caso de la archivística.

No obstante, se hallan obstáculos difíciles de evitar cuando se estudia la temporalidad, incluso de la archivística:

- Por un lado, como es sabido, la duración de los fenómenos histórico-archivísticos no es igual en todos los sitios. Es necesario, por tanto, hacer sincronías entre las diferentes evoluciones sin tener que romper la individualidad del objeto histórico;

1 La expresión Telépolis no es propia. Se ha extraído de las brillantes obras de J. Echevarría (1994; 1999).

2 Este trabajo se ha financiado por la Junta de Extremadura, en el marco de la convocatoria competitiva establecida de Ayudas a Grupos de Investigación Reconocidos (GR 15111), Fondos FEDER. (Grupo de Investigación ARDOPA: Archivística y Documentación del Patrimonio). 
- Por otro lado, hay diversidad de ritmos en el desarrollo de los procesos históricos. Una manifestación puede producirse en un período de tiempo reducido en un lugar y extenso en otro. Por tanto, se deberá tener en cuenta la cadencia histórica al analizar la temporalidad de una disciplina.

- Por último, la multiplicidad de duraciones históricas. No es similar el tiempo efímero de una disciplina que aquél otro que define sus estructuras internas. Recordemos, en este sentido, los tres tiempos que ya describía la conocida Escuela de Annales (Borguiere, 2008):

- El Tiempo Corto o aquel que afecta a los acontecimientos. Se trata del preferido para el análisis positivista. Examina las modificaciones que suceden a gran velocidad en cada instante. Por ejemplo, cualquiera de las variadas mudanzas de carácter técnico que tienen lugar, a nivel interno, en cualquiera de los grandes archivos.

- El Tiempo Mediano, o aquel que afecta a las coyunturas. Se trata de aquel conjunto de escenarios articulados entre sí que caracterizan un contexto histórico. Lógicamente, las varianzas tienen lugar a menos velocidad que los acontecimientos, y pueden ser cíclicas, como aquéllas que describe Simiand al referirse a las coyunturas económicas (1903). Por citar un ejemplo, el desmantelamiento del Antiguo Régimen en pocos años y las necesidades que devienen de una serie de medidas para la conservación documental y las consiguientes reglamentaciones.

- Y el Tiempo Largo, o aquel que afecta a las estructuras. Hace referencia a aquellas realidades históricas que permanecen constantes, más allá de las influencias de acontecimientos y coyunturas. Se trata, por tanto de una historia casi inmóvil, esto es, de movimientos lentos, que nos permiten estudiar las formas de ver y de interpretar el mundo. Por ejemplo, las características o propiedades que definen la archivística de propiedades jurídico-administrativas frente a la de caracteres historicistas. 
En estas circunstancias y hasta este punto, en el presente estudio no se considerará el tiempo externo como forma de análisis de la temporalidad. Este sería el tiempo que toma la cronología como medida de la sucesión de los acontecimientos, y sirve para establecer el antes y el después, una especie de encasillado en donde situar los hechos o primera categorización del transcurso temporal. Por el contrario, se tratará de basarse en el tiempo interno como forma de análisis de la temporalidad archivística, para lograr así una categorización racional de la disciplina y sistematizar así los cambios y duraciones de su Historia.

En este sentido, se considera que el instrumento específico del tiempo interno es el periodo histórico, pues representa la categoría historiológica base para analizar la temporalidad de la Historia de la Archivística. Sería, en palabras de Julio Aróstegui "aquel lapso de tiempo en el que una combinación determinada y bien caracterizada de factores permanece conformando un sistema de algún tipo, cuyo modelo puede ser establecido, y que podemos llamar un espacio de inteligibilidad histórica" (Aróstegui, 1995).

Ciertamente, la categorización de la historia de la archivística en períodos históricos ha sido utilizada en la historiografía, aunque sin unanimidad:

- Dos de los primeros autores que segmentaron la archivística fueron Eugenio Casanova y Adolfo Brenneke. El primero expone una historia de la disciplina fraccionada en cuatro periodos y explica de forma exhaustiva para cada una de las etapas las instituciones archivísticas que surgen, los avances reglamentarios que tienen lugar, el contexto institucional y administrativo, etc., observando, en definitiva, un progresivo desarrollo conceptual (Casanova, 1928). Por su parte, Adolf Brenneke señaló tres grandes etapas: un primera, de carácter técnico y experimental; una segunda, sumida en el contexto racional e ilustrado, y que derivaría en un sistema de clasificación archivístico de personalidad deductiva y de solvente carga teórica; y, por último, una tercera de consolidación de 
los principios teóricos como nueva forma de clasificación y organización archivística (Brenneke, 1953).

- Sin embargo, han sido por un lado el francés Robert Henri Bautier (1968), iniciador de la denominada escuela Francesa, y por otro los italianos Leopoldo Sandri (1968) y Elio Lodolini (1991) los que, desde criterios y agentes diferentes, han periodizado la disciplina archivística, tal vez de forma más comprometida y clarividente. Para Bautier, la división corresponde, en gran medida, con las grandes épocas en que podemos dividir la historia de la humanidad. Así, segmenta la Historia de la Archivística en cuatro grandes etapas: Edad Antigua o Archivos de Palacio, con un concepto del archivo patrimonial y administrativo, Edad Media o Tesoros Documentales (de chartes), que desarrolla el concepto anterior, Edad Moderna o los Archivos como arsenal de la autoridad, época en la que nacen los Archivos de Estado y surgen de forma gradual cada uno de los principios de la archivística, y Edad Contemporánea o Archivos como laboratorios de la bistoria, donde los archivos pasan a convertirse en un instrumento de la historia. En definitiva, el poder político y las transformaciones sociales como elementos definitorios de la evolución archivística. Para Sandri y Lodolini, la división de la Archivística atiende más a la evolución del concepto mismo de archivo que a las etapas históricas clásicas. Distinguen así tres etapas: la primera, donde predomina un concepto patrimonial y administrativo del archivo, que abarcaría hasta el siglo XVIII y destaca la clasificación orgánica de la documentación; la segunda, en la que prevalece un concepto historicista del Archivo, hasta el siglo XIX, en la que se subraya el valor histórico de los documentos, la documentación por materias y la primacía de la investigación histórica; y, por último, la tercera, ya a partir de las décadas casi centrales del siglo $\mathrm{XX}$, donde se conjugan las etapas anteriores en beneficio de una concepción integral del archivo, fusionándose el valor jurídico e histórico de los documentos y surgiendo la teoría científica de la archivística a través del principio de procedencia, la teoría de las tres edades y 
la teoría de los valores. En definitiva, frente a Bautier, estos autores se fijan más en el orden interno y conceptual de la archivística que en el orden externo contextual e histórico. Por ello, consideramos que ambas periodizaciones no se contraponen, sino que más bien pueden superponerse en el análisis, dado que reflejan diferentes percepciones de la evolución archivística. Por último, otros autores han resuelto el problema mediante sendas periodizaciones. Así, el profesor Cruz Mundet habla de Período Pre-Archivístico y Período Archivístico, la profesora Mendo Carmona, distingue la archivística empírica, jurídica, historiográfica y actual; el profesor Romero Tallafigo reconoce Archivos del Antiguo Régimen y Archivos del Nuevo Régimen. Nosotros mismos, hemos conjugado las dos grandes escuelas y hemos hablado de archivística empírica, patrimonial y jurídico-administrativa, como teoría especulativa y ciencia historiográfica, e integral.

\section{OBjeTIVOS, HIPÓTESIS Y METODOLOGÍA}

Expuesto lo anterior, tres son los objetivos que nos proponemos:

1. Racionalizar la vinculación existente entre las grandes épocas de la humanidad y la evolución del concepto de archivo.

2. Relacionar el contexto cultural e historiológico con el archivístico, esto es, entrever el componente histórico-racional frente al lineal y evolutivo.

3. Insertar nuestra investigación en lo que denominamos Historia Cultural de la Archivística.

Todo ello, parte de tres grandes hipótesis, naturalmente supeditadas a los objetivos:

1. Entiender que el contexto histórico-filosófico influye directamente en la configuración archivística, en el concepto de 
archivo y condiciona su existencia (conservación, organización y finalidad).

2. Considerar que la atmósfera intelectual (medieval, renacentista, barroca, ilustrada y decimonónica) repercute en la evolución del concepto de archivo y la mutación de éste es signo, a su vez, de un giro histórico ("facendo lo storico fa dell'archivistica" Sandri, 1968).

3. Concebir que todo ello tiene un reflejo en la evolución ética de la disciplina: de un sistema de construcción del individuo y de la disciplina (ss. XVI-XVII) a otro de la historia como progreso y, por consiguiente, de la necesidad de una memoria ética (s. XIX preferentemente); y de ahí, a la reciente función informativa de la disciplina $y$, por tanto, la que podríamos denominar como ética de la comunicación y la información ( $2^{\mathrm{a}}$ mitad del s. XX)

Los criterios metodológicos seguidos han sido los siguientes:

1. La selección de tres tiempos diferentes para entrever aquellas características que vinculen el contexto cultural e historiológico con el archivístico. Aunque más tarde quedarán suficientemente explicitadas, dichos tiempos serán los que siguen:

a. Tiempo $1^{\circ}$ : De la ciudad de Dios (S. Agustín) a la construcción del individuo, o de la idea de providencia y los primeros intentos de creación de archivos centrales a la consolidación del Estado Moderno y la formalización de los primeros Archivos de Estado (el Archivo de Simancas).

b. Tiempo $2^{\circ}$ : De la ciudad de los hombres (P. Hazard) a la idea de historicidad, o de la identidad nacional a los Archivo Históricos Nacionales.

c. Tiempo $3^{\circ}$ : De Telépolis (J. Echevarría) a la idea de memoria artificial, o del determinismo tecnológico al documento electrónico.

2. Racionalizar dicho análisis mediante el breve examen de algunas imbricaciones sociales y culturales para cada uno de los tiempos. Y así, percibir la compleja configuración de la archivística en su desarrollo evolutivo, analizar el complejo 
entramado de interacciones sociales y culturales que actúan como ingredientes condicionantes de la forma en que se articularon los archivos y que acaban definiendo el tiempo archivístico de forma macroestructural, y extraer algún reflejo en la evolución ética de la disciplina.

En definitiva, no se pretende, en modo alguno, resumir sintéticamente la historia lineal y evolutiva de la archivística, sino sugerir la posibilidad de una historia racional y cultural.

Para el análisis de cada una de las temporalidades se fijará en primer lugar en las características histórico-filosóficas y en las particularidades de carácter puramente archivístico, para después vislumbrar las interacciones socio-culturales y sus implicaciones éticas.

\section{Tiempo $1^{\circ}$ : De la 'Ciudad de Dios' a la construcción} DEL INDIVIDUO. DE LOS PRIMEROS ARCHIVOS CENTRALES A LOS Archivos de Estado

Con la expresión agustiniana Ciudad de Dios, se hace referencia a una etapa teocéntrica aunque de paulatina construcción del individuo, de afirmación de las monarquías absolutas y de formalización de los archivos de Estado.

Durante la Baja Edad Media y los siglos XVI y XVII se da, a modo de tono continuo, una primacía de la concepción teológica y la plenitud del Providencialismo, donde toda la historia universal prueba la intervención continuada de la providencia divina. El personaje que pudiera representar esta concepción es el intelectual francés Bossuet, defensor del origen divino del poder (Bossuet, 1772). Al mismo tiempo, el orden natural acaba confundiéndose con el sobrenatural, y las escrituras, que tienen origen divino, no deben ser tratadas como un texto puramente humano. Se pretende así subrayar un teocentrismo trascendente, ajeno a la naturaleza humana.

Sin embargo, fundamentalmente con el Renacimiento, se constata, en el marco teórico anterior, la paulatina construcción del 
individuo. Los sistemas filosóficos de Bacon y su propósito de fundar una ciencia sobre la naturaleza de las cosas, Descartes y su nuevo método o proceso de renovación filosófica, Fontenelle y su idea de progreso a la narración histórica o Vico reconociendo a la historia como ciencia nueva, suponen los cimientos de la construcción del individuo. Asimismo, el Humanismo renacentista y las primeras exégesis bíblicas, recordemos a Spinoza cuando propone interpretar la Biblia igual que se estudia la Naturaleza (1670), o a Richard Simon y su Historia crítica del Antiguo Testamento (Simon 1678), o el incipiente valor del hombre como sujeto histórico, conllevan la construcción del individuo.

Por otro lado, es el tiempo de la construcción del Estado Moderno, de claros antecedentes bajomedievales: con instituciones burocratizadas y reguladas normativamente, con asunción de responsabilidades gubernativas y judiciales por funcionarios profesionalizados, con instituciones que toman decisiones sin consultar directamente con el rey, con mecanismos normalizados de comunicación administrativa entre las instituciones entre sí y con el monarca y con nuevos procedimientos administrativos. Naturalmente, todo ello se encuentra vinculado con la afirmación de las monarquías absolutas sustentadas en el derecho divino y en una concepción histórica providencialista.

Archivísticamente, predomina, al hilo de lo estudiado en otras ocasiones, una evolución desde una archivística inductiva y funcional a otra como doctrina patrimonial y jurídico-administrativa. La archivística empieza siendo un procedimiento empírico sin corpus teórico, donde los métodos de clasificación y ordenación de documentos son el resultado de una elemental práctica funcional, y donde el archivo adquiere una consideración como entidad propia al conferir fe pública del valor probatorio de los documentos. Posteriormente, la archivística adquiere una función patrimonial y jurídico-administrativa. Esto es, el archivo se convierte en un elemento fundamental de la práctica administrativa estatal, y por tanto adquiere una función predominantemente jurídico-política. Asimismo, el archivo ofrece a los soberanos una documentación útil para la afirmación de los derechos de la Corona y del Estado, y 
para el ejercicio del poder en sus territorios. Durante este momento se provee al sistema administrativo de una mayor complejidad de la práctica documental, fruto de la paulatina dificultad institucional y administrativa. En consecuencia, el archivo resulta ser un instrumento base de la organización administrativa del Estado que trae como resultado el surgimiento de los Archivos de Estado. El archivo se transforma, por tanto, en un mecanismo de poder de las monarquías absolutas, esto es, en uno de los procedimientos de dominio y control, formando parte de la función coercitiva del Estado y de la teoría providencialista que justifica el derecho divino. El archivo, pues, como instrumento del Absolutismo.

Al hilo de lo expuesto, en la Ciudad de Dios hay algunas interacciones sociales y culturales que actúan como ingredientes condicionantes de la forma en que se articularon los archivos y que lo acaban definiendo de forma macroestructural.

Una de ellas es lo que denominamos como la práctica eclesiástica. Los poderes religiosos siempre han tenido un denodado empeño por transmitir la doctrina de modo unilateral y completo. Así, en gran medida, el documento eclesiástico es el resultado de garantizar la autenticidad doctrinal y la tradición eclesiástica. La doctrina eclesiástica se basa en un conjunto articulado de preceptos que, pese a su importancia, puede ser reinterpretada e incluso transmitida de forma parcial o subjetiva. De ahí el empeño, por transmitirla de un modo unilateral y completo. En consecuencia, la práctica eclesiástica influye en el desarrollo archivístico mediante sus pretensiones de conservación e intemporalidad del documento eclesiástico, y a través de archivo en la defensa de la concepción teológica y la plenitud del providencialismo. Asimismo, desde un punto de vista cultural, buena parte de los formulismos y usos que envuelve al documento escrito proviene de la tradición eclesiástica: las invocaciones de los documentos medievales y modernos o el secretismo de la palabra de Dios mediante su escriturado en el libro sagrado son ejemplos claros. Por último, la administración eclesiástica favorecerá la complejidad institucional de la administración civil. En otros términos, hay una relación entre 
la acelerada práctica documental, el desarrollo de los archivos y la defensa de la doctrina providencialista.

Otra interacción socio-cultural que ha condicionado el desarrollo de los archivos de forma preeminente en este primer momento ha sido la necesidad de salvaguardar jurídicamente los derechos de los particulares e instituciones. El documento escrito deviene en ser el principal instrumento probatorio, lo cual vino propiciado por la recepción del Derecho Romano-Canónico transmitido a través de la recopilación justinianea. En consecuencia, el Derecho Romano, de grandes influencias culturales en la Edad Moderna, influye en el desarrollo de los archivos. En este orden de cosas, otro de los elementos que explica la proliferación de documentos de archivo es el notariado. Se trata de personal que acredita la autenticidad del proceso de escriturado de un documento y se responsabiliza de su correcta custodia. El notario es, por tanto, elemento clave de las monarquías autoritarias en los ss. XVI y XVII y posteriormente de cualquier otro sistema político.

Por último, otra interacción político-cultural que se refleja en el despliegue archivístico es la instrumentalización política y la burocracia. Es evidente que el desarrollo de los archivos está ligado a la complejidad de las diferentes formas políticas. Prueba de ello es el impulso de la burocracia. Ésta crea mecanismos normalizados de comunicación administrativa entre las instituciones, entre sí y con el monarca; favorece el surgimiento de procedimientos administrativos regularizados (vía de proceso y vía de expediente) y se convierte en requisito para convertir al archivo en un instrumento de privilegio y eficacia. Como resultado de todo ello, el archivo ha ocupado históricamente un puesto de poder con tres características al menos: favorece el rigor y la agilidad administrativa, permite un control jerarquizado de las actividades gubernativas o judiciales y permite un control sobre el conjunto de los particulares que, en algún momento, han entrado en contacto con la administración.

Se ve, en definitiva, de qué forma hay un paralelismo entre el desarrollo archivístico y la consolidación del Estado Moderno 
como forma política de control y dominio del individuo que empieza a ser sujeto histórico a través de las corrientes humanistas.

Esta reciprocidad entre el desarrollo de la archivística y las interacciones socio-culturales, tiene su reflejo en la evolución ética de la disciplina. Por un lado, los archiveros deben tener una formación administrativa y jurídica y se convierten en funcionarios, algunos, de alto nivel en la administración de las monarquías autoritarias. Por otro, los archivos y su disciplina inciden en el paso de una ética moral y cristiana a otra de tintes humanistas. Véase dos motivos:

- Políticamente, porque la disciplina incide en el discurso ético que circula evolutivamente desde una posición donde la virtud está en la conservación del poder (Maquiavelo), donde la gente busca seguridad participando en un contrato social en el que el poder original de cada persona se cede a un soberano que, a su vez, regula la conducta. (Hobbes), y donde, sin embargo; el fin del contrato social es limitar el poder absoluto de la autoridad y, como contrapeso, promover la libertad individual (Locke).

- Por otro lado, porque se considera que la archivística, a medida que se avance en el tiempo, va a reflejar la importancia del individuo como sujeto histórico, lo cual traerá consigo la relevancia del documento como fuente histórica. Aunque esto se verá fundamentalmente en el $2^{\circ}$ tiempo archivístico que se describirá a continuación, en este primer momento, autores como Bacon (actitud empirista) o Descartes (actitud racionalista), a pesar de su poca creencia en la historia, darán ocasión a la puesta en marcha del pensamiento historiológico que se verá en autores como Vico (Nueva Ciencia) o Fontenelle (idea de progreso histórico). Posteriormente ya vendrán autores como Voltaire, Montesquieu, Turgot, Fergusson o Condorcet que consolidan esta perspectiva. 
Tiempo $2^{\circ}$ : De la CIUDAD DE lOS HOMBRES A LA IDEA DE HISTORICIDAD; O DE LA IDENTIDAD NACIONAL A LOS ARCHIVOS Históricos Nacionales

El $2^{\circ}$ tiempo que se quiere esbozar queda representado con la denominación Ciudad de los Hombres extraída de la maravillosa obra de Paul Hazard (1981). Siguiendo a este autor, la presente temporalidad presenta una triple configuración:

- En primer lugar tuvo lugar el proceso al cristianismo, basada en la crítica universal, el proceso al Dios de los cristianos, los argumentos contra la religión revelada y los intentos de integrar la novedad en la tradición.

- Posteriormente, la construcción de la ciudad de los Hombres, bajo las claves de la búsqueda de la felicidad, el espíritu racional, la religión natural, la defensa de la educación y la búsqueda del bienestar.

- Por último, encontramos ciertas disgregaciones o incoherencias: las que vienen de querer acomodar la naturaleza -en su enorme complejidad- a la razón, aquellas otras que inspiran los orígenes filosóficos del concepto de sentimiento, de libertad, de pueblo y de romanticismo; y, por último, las divergencias surgidas de los diferentes deismos divergentes, o de la relación entre lo humano y lo divino.

Fruto de la construcción del individuo y de la sustitución de Dios por el hombre, surge en su plenitud la idea de historicidad, que tanto reflejo tendrá en la disciplina archivística. Se ve, en consecuencia, como durante el s. XVIII y con mayor plenitud en el s. XIX, surge la nueva idea de historia en conexión con la idea de naturaleza. De esta manera, por un lado, se pretende buscar el orden histórico similar al orden natural; y por otro, la historia se configura como una ciencia autónoma con fundamentación filosófica. En definitiva, la historia contribuye, pues, a derribar la concepción teológica y providencialista. 
Todo ello puede ser analizado siguiendo a diferentes autores que, desde concepciones prioritariamente filosóficas, acabarán determinando la concepción archivística, que es una de las hipótesis de este trabajo. Así, sin pretensiones de ser exhaustivos, Voltaire da el paso de la teología de la historia a la filosofía de la historia, de tal forma que la explicación de la historia recurriendo a la providencia de Dios es olvidada para acudir a la explicación humana. Por su parte, Montesquieu instituye la explicación determinista de la historia; Turgot representa la idea de progreso en la interpretación histórica universal; Rousseau defiende la perspectiva naturalista de la historia y frente a la corriente progresista, propugna por un retorno al estado primigenio del hombre (doctrina del buen salvaje); Fergusson defiende la teoría progresista de la historia (si bien admite etapas de retroceso); Condorcet establece la doctrina del progreso al máximo, esto es, el optimismo histórico que alcanza el progreso futuro; Dilthey racionaliza su defensa de la crítica histórica; Ritter se configura como uno de los grandes exponentes de la filosofía de la historia; Kant vincula naturaleza e historia dado que, como es sabido, las acciones del hombre están determinadas por las leyes universales de la naturaleza, y Herder se configura como una figura estelar en la filosofía de la historia al enlazar con el romanticismo del s. XIX. Así, empieza combinando el providencialismo del XVII con el progresismo del XVIII. Defiende una visión lineal de la historia y acaba colocando al hombre - y no a grupos de hombres, como sujeto de la historia. Herder entiende la historia fundamentada en conceptos como progreso, naturaleza, hombre y providencia. Son conceptos heredados del s. XVII, pero enfocados desde una perspectiva nueva, que perfila ya sobre su proyección hacia el s. XIX. En resumen: Vico instituye la ciencia nueva de la historia, Voltaire la denomina Filosofía de la historia, y Herder la fundamenta filosóficamente (Alonso, 1971).

Por su parte, el s. XIX es el gran siglo de la historia, con tres etapas, que simplemente señalamos: el Romanticismo, que finaliza con las grandes construcciones del idealismo alemán de Fichte, Schelling y Hegel que consideran la historia como un desarrollo de la idea de libertad y formando parte del despliegue del espíritu 
universal; el Realismo, con el Positivismo, el Materialismo y la aparición de las grandes escuelas científicas. Es el caso de Compte y de cómo el espíritu humano recorre tres estadios: el teológico, el metafísico y el positivo; o Marx y su materialismo histórico, y su interpretación de la historia como lucha de clases; y la historia científica y el Historicismo, o el interés por la historia de la cultura y la historia de las instituciones, política y social. Así, Dilthey, que es el inaugurador del historicismo, Lessing y su escepticismo histórico, Weber y su interpretación sociológica de la historia, Jaspers y su interpretación existencialista de la historia, Spengler, para quien las culturas son como organismos que nacen y mueren y Toynbee, para quien son las sociedades las que surgen y decaen.

En definitiva durante todo este tiempo, la historia resulta ser filosóficamente un elemento edificante de la construcción del individuo como sujeto histórico y, como consecuencia, dispositivo sustancial de la construcción de la identidad nacional de los pueblos.

En relación con lo dicho, la Archivística es considerada como una disciplina necesaria para la formalización del concepto de historia que se formaliza en el contexto descrito. Al margen, con la demolición del Antiguo Régimen un número ingente de documentos cesaron de súbito en su función primaria de garantes de prueba. En consecuencia, fue necesario concentrar la documentación de las instituciones ya desaparecidas, y distribuirla en archivos cuya única orientación futura habría de ser el servicio para la investigación y la cultura. Son los Archivos Históricos.

Al mismo tiempo, surge en toda Europa un fuerte sentimiento nacionalista, que, a través de las fuentes originales ubicadas en los archivos, busca en su pasado las raíces más profundas de la identidad nacional. En consecuencia, los documentos archivísticos cobran una especial relevancia como elementos imprescindibles en la investigación histórica. La solución ante la nueva demanda fue la creación de grandes depósitos documentales en los que concentrar dicha documentación. Son los Archivos Nacionales

En consecuencia, el concepto de archivo adquiere notablemente una nueva dimensión: deja de ser concebido únicamente como una institución con fines patrimoniales o administrativos para 
desempeñar fundamentalmente una función cultural e histórica, esto es, para la investigación. En este sentido, la archivística es considerada como una disciplina auxiliar de la investigación histórica, al igual que lo son la paleografía o la diplomática. En definitiva, a decir de Bautier, los archivos se convierten en laboratorios de la historia, dejando de lado la función que había primado hasta entonces de servicio a la administración

Al hilo de lo dicho, en este momento hay un importante desarrollo teórico de la disciplina impulsado por la formalización del Principio de Procedencia. La disposición de la archivística como ciencia auxiliar de la historia tiene como consecuencia directa el desarrollo de la descripción y el aumento progresivo de instrumentos heurísticos que permitían al historiador encontrar fácilmente la información que demandaban. De esta forma, comienzan a proliferar guías, inventarios, catálogos, índices, colecciones diplomáticas, etc. Y como consecuencia de todo ello, se produce una expansión de la formación profesional específica, creación de grandes centros de enseñanza archivística y desarrollo legislativo archivístico

En este $2^{\circ}$ tiempo, fruto de todo lo dicho, hay una interacción social y cultural que actúa como ingrediente sustancial de la forma en que se articularon los archivos y que lo acaban definiendo de forma macroestructural. Se trata de la memoria histórica. Resulta ser una función relativamente reciente por la que los fondos se conservan más allá de las necesidades administrativas para las que se gestaron. Se hace referencia fundamentalmente a dos cuestiones: por un lado, mediante lo que denominamos como la concepción cientificista de la bistoria. Se hace mención a la necesidad de que la historia y su formalización teórica esté basada en fuentes auténticas. De este modo: el tecnicismo, unido a la concepción empirista de la historia, convertían al documento escrito en protagonista del trabajo del historiador. En definitiva, el documento de archivo se comporta como un instrumento verificador del discurso histórico. De ahí la necesidad de que los documentos estén arreglados, sean accesibles al investigador y se encuentren clasificados y descritos adecuadamente. Por otro lado, la historia es considerada como un 
instrumento de carácter cultural y politico. De carácter cultural, porque la historia es una cuestión de interés colectivo, donde los documentos son considerados monumentos, enlazando todo ello con la visión del Patrimonio Histórico como bien público. Y de carácter político, dado que son constatables los intereses políticos de las monarquías europeas cada vez más preocupadas por cuestiones relacionadas con lo que hoy se llamaría opinión pública e identidad nacional. Piénsese, por ejemplo, en la creación del Archivo de Indias como alternativa a la divulgada Leyenda negra en la colonización americana, o en la legitimación de los discursos nacionalistas del s. XIX, basada en la historia como arma política.

En conclusión, lo que se viene denominando como memoria histórica, requiere ineludiblemente de archivos para cumplir sus objetivos. Dicho de otra manera, para que la historia esté realizada con rigor científico y para que pueda ser utilizada como instrumento cultural y político necesita de documentos organizados científicamente, lo cual implicará el desarrollo de un tipo de archivística en la que predominará el perfil historicista.

Esta reciprocidad entre el desarrollo de la archivística y las interacciones socio-culturales, tiene su reflejo en la evolución ética de la disciplina. Por un lado, se produjeron cambios en los responsables al frente de los archivos, que de funcionarios, conocedores de la administración a la que servían, se pasó a eruditos investigadores amantes de la historia. Por otro, porque la archivística y los archivos, desde diferentes perspectivas, colaboraron, desde las nuevas concepciones filosóficas de la historia, en la formalización de la ética del individuo ${ }^{3}$ y de la ética colectiva. ${ }^{4}$ En este sentido, la memoria histórica se configura como elemento sustancial de los diferentes sistemas éticos (Mill y el utilitarismo, Shopenhauer y el pesimismo, Kierkegaard y la importancia de la decisión individual, Marx y el problema del hombre alienado o Nietzsche y la

3 Piénsese en la expresión de Kant: "Obra como si la máxima de tu acción pudiera ser erigida, por tu voluntad, en ley universal de la naturaleza"

4 Piénsese, por ejemplo, en que para Hegel la ética no es contrato individual, sino un crecimiento natural que surge en la familia y culmina, en un plano histórico y político, en el Estado. 
crítica a los valores cristianos). De ahí, el despliegue de la archivística durante toda esta época.

\section{Tiempo 3: De Telépolis (J. Echevarría) a la idea de MEMORIA ARTIFICIAL; O DEL DETERMINISMO TECNOLÓGICO AL DOCUMENTO ELECTRÓNICO}

El 3er. tiempo que se quiere esbozar queda representado con el término Telépolis, en expresión de J. Echevarría (1994) se halla en un tiempo nuevo que se define por la confluencia de tres procesos: la universalización de lo digital, la universalización del acceso a sus prestaciones y la consolidación de audiovisual como medio universal y dominante de comunicación (Bonal et al., 1996).

Echevarría describe este tiempo con una serie de características, todas ellas interrelacionadas entre sí, que nosotros simplemente nombramos y que pueden ser útiles para referir someramente el nuevo espacio social resultante (1999):

- La distalidad (y no la proximidad): los objetos e instrumentos pueden estar muy alejados entre sí.

- La representacionalidad o realidad virtual (y no la presencia física): casi ninguna de las acciones requieren de la presencia física de los actores, objetos e instrumentos.

- La informacionalidad: (y no la materialidad): lo esencial no son los átomos sino los bits; no la materialidad sino la información que se difunde.

- La artificialidad (y no la naturalidad): la mayoría de los componentes son elementos artificiales. Esto trae algunas consecuencias, como las formas de inteligencia artificial o la sociedad del espectáculo.

- La asincronía (y no la sincronía): la simultaneidad deja de ser necesaria. El ciberespacio crea una estructura muy diferente al del tempus fugit, y los agentes y objetos pueden actuar o ser afectados por procesos producidos en tiempos muy distantes. 
- La compresión (y no la extensión del espacio tridimensional): lo importante no es la extensión sino las conexiones.

- La aceleración (y no la lentitud): la velocidad acelerada de los flujos modifica continuamente los procesos y formas de actuación.

- La inestabilidad (y no la estabilidad): producida por el diseño y mantenimiento artificial, y el envejecimiento rápido de los materiales y la renovación continua.

- La globalidad (y no la localidad): las acciones y sus consecuencias pueden ejercerse en todo el globo.

- La bisensorialidad (y no la pentasensorialidad): dado el predominio del carácter audiovisual

- La transnacionalidad (y no el entorno de las naciones-Estados): emergen así formas humanas trans-nacionales.

- La interdependencia (y no la independencia o soberanía): porque las decisiones de uno dependen de las de los demás, por la fragilidad de los medios tecnológicos y por encontrarnos en un entorno sistémico y no atomista.

- El consumo (y no la producción).

\begin{tabular}{|c|c|}
\hline $\begin{array}{l}\text { - Proximal } \\
\text { - Material } \\
\text { - Presencial } \\
\text { - Natural } \\
\text { - Sincrónico } \\
\text { - Extensión } \\
\text { - Circulación lenta } \\
\text { - Estabilidad } \\
\text { - Localidad } \\
\text { - Pentasensorial } \\
\text { - Nacionalidad } \\
\text { - Autosuficiencia } \\
\text { - Producción }\end{array}$ & $\begin{array}{l}\text { - Distal } \\
\text { - Informacional } \\
\text { - Representacional } \\
\text { - Artificial } \\
\text { - Asincrónico } \\
\text { - Compresión } \\
\text { - Circulación rápida } \\
\text { - Inestabilidad } \\
\text { - Globalidad } \\
\text { - Bisensorial } \\
\text { - Transnacionalidad } \\
\text { - Interdependencia } \\
\text { - Consumo }\end{array}$ \\
\hline
\end{tabular}

Fuente: Elaboración propia, a partir de Echevarría, J. (1999) Los señores del aire: telépolis y el tercer entorno.

Pues bien, todo ello conlleva un nuevo concepto de memoria, que afectará, sin duda alguna a la archivística. La memoria en este tercer tiempo se caracteriza por dos cualidades: en primer lugar, por su exteriorización radical, y en segundo lugar porque se 
vincula a la digitalización y tiene una configuración artificial. Ello está ocasionando, a este modo de ver, una consecuencia que causa cierta incertidumbre en la configuración del saber. Por un lado, y como resultado de esta transformación general a la que se está asistiendo, la naturaleza del saber no está quedando intacta. Todo lo que en el saber constituido no sea traducido al lenguajemáquina será dejado de lado. De esta forma, los productores y los utilizadores del saber deberán poseer los medios de traducción suficientes. Por otro, con la hegemonía de la informática y de los nuevos lenguajes se está produciendo lo que Lyotard denomina "una potente exteriorización del saber con respecto al sabiente en cualquier punto en que este se encuentre en el proceso de conocimiento" (1989). Aquel principio, según el cual la adquisición del saber es indisociable de la formación del espíritu y de la persona, está siendo dejado de lado, a pasos agigantados. En definitiva, tal y como ha quedado ya dicho, en Telépolis, la información es la mercancía más privilegiada, medio indiscutible del poder. Dicho con otras palabras: el saber es un valor, y es y será producido para ser vendido y consumido, para ser valorado en una nueva producción. En este sentido, la posesión de información deviene en poder; y en consecuencia, la información será puesta en circulación, no en virtud de su valor formativo, sino según los mismos principios, redes y sistemas que la moneda. Llegados a este punto, la pregunta que nos hacemos es ¿quién controla el saber? si el hombre sabe que el saber es una mercancía informacional, una fuente de ganancias y un medio de decidir y de controlar ¿dónde reside la legitimación en el tercer momento? (Lyotard, 1989).

En relación con lo dicho, la archivística es considerada como una disciplina integral e inserta en el marco de la Sociedad de la Información. Es el periodo de desarrollo archivístico, pasando a ser, según algunos autores, una verdadera ciencia autónoma. Se produce una ampliación del campo de actuación, mediante la acuñación del ciclo vital de los documentos y la teoría de las tres edades. Ello trae consigo una expansión científica de la archivística, claramente percibida, bajo nuestro criterio, por cinco características: un progreso historiográfico de la literatura, un importante 
desarrollo normativo, un despliegue de la política internacional, un indiscutible aumento del asociacionismo profesional y el reconocimiento oficial de la archivística en la Universidad Española. Y todo ello, cada vez más, con la inserción, aunque no sin ciertos recelos, de la disciplina en el campo de las ciencias de la documentación.

Otra de las características fundamentales de la archivística, fruto del contexto cultural del tiempo, es el determinismo tecnológico. El enorme impacto que genera en los sistemas de gestión de archivos la tecnología y sus diferentes ámbitos, ocasiona novedades teóricas, un nuevo tratamiento metodológico para los nuevos archivos y documentos electrónicos, modificaciones en los métodos de trabajo, alteraciones de las prácticas y principios tradicionales, nuevas estrategias en la gestión de documentos a través de los metadatos y sus diferentes aplicaciones, y nuevos problemas: ¿Cómo mantener la procedencia?, ¿Cómo incorporar la selección documental al diseño de aplicaciones?, ¿Cómo facilitar el acceso? ¿Cómo preservar? A todo ello se suma, los excesivos formulismos normalizadores que pretenden alcanzar, en ocasiones, lo soslayable.

Fruto de todo lo dicho, en este tercer tiempo hay una interacción cultural que actúa como ingrediente condicionante de la forma en que se articulan los archivos y que lo acaban definiendo de forma macroestructural. Se trata de la función informativa. Considero que se puede describir con tres elementos que ya han quedado señalados. Por un lado, se ve cómo es la difusión y el acceso a la información conservada en los documentos (y no la memoria ni la gestión administrativa) el proceso macroestructural de mayor relevancia de esta etapa, y es la que justifica la inserción de la disciplina en las Ciencias de la Información. Así, los lenguajes documentales y la gestión de la información, elementos comunes a otras disciplinas, son sustanciales de la visibilidad de nuestra disciplina en nuestra época. En segundo lugar, la consideración de los archivos como unidades de información que en su quehacer siguen una concepción sistémica. De esta manera, el archivo es percibido como un sub-sistema de información interno del sistema global de información de una entidad pública o privada. Y a su vez estará compuesto de los subsistemas de clasificación, conservación 
y eliminación, y descripción y recuperación. Y en tercer lugar, dos elementos que tecnifican la disciplina: por un lado, la aplicación de formulismos y normativas a los diferentes aspectos del quehacer archivístico, y por otro, la traducción a lenguaje máquina, mediante digitalización, de los documentos y sus contextos. Normatividad y digitalización fruto también del contexto histórico, y mediatizado por las influencias de las nuevas perspectivas de la documentación y el determinismo tecnológico.

Esta reciprocidad entre el desarrollo de la archivística y las interacciones socio-culturales, tiene, como en tiempos anteriores, su reflejo en la evolución ética de la disciplina. Por un lado, porque el archivero tiene una formación específica: ya no es un gestor de la administración o un historiador sino una persona formada en el ámbito de la disciplina. Durante este tercer tiempo se realizan diferentes códigos éticos, que tienen que ver con las siguientes parcelas, todas ellas dignas de análisis: la integridad de los bienes documentales, la conservación del principio de procedencia, la autenticidad de los documentos, el acceso a los documentos y privacidad, la imparcialidad o la excelencia profesional. Todas ellas en el contexto de una archivística mediatizada por la función informativa.

\section{CONCLUSIONES}

Llegados a este punto, se puede concluir con tres breves aseveraciones:

- El contexto histórico-filosófico influye directamente en la configuración archivística, en el concepto de archivo y condiciona su existencia (conservación, organización y finalidad);

- La atmósfera intelectual del contexto repercute en la evolución del concepto de archivo y la mutación de éste es signo, a su vez, de un giro bistórico;

- Y, en definitiva, que todo ello tiene un reflejo en la evolución ética de la disciplina, donde la construcción del individuo, la necesidad ética de la memoria y la ética de la comunicación y 
Uso ético de la información...

la información contextualizan el paso de una archivística que transita de la función coercitiva a la necesidad informativa.

\section{Bibliografía}

Alonso Núñez, J. M. (1971). El pensamiento historiológico alemán en el s. XVIII: investigaciones sobre Herder y los orígenes de la filosofía de la Historia. Madrid: Facultad de Filosofía y Letras.

Aróstegui, J. (1995). "La periodización en la historiografía: el espacio de inteligibilidad". La investigación histórica: teoría y método. Barcelona: Crítica.

Bautier, H. (1968), "La phase cruciale de l'histoire des archives: la constitution des dépôts d'archives et la naissance de l'archivistique (XVIème-XIXème siècle)", $A r$ chivum, vols. 18-19, 45-61.

Bonal Zazo, J. L., P. L. Cadarso, C. Castro Castro, A. B. Curado Fuentes y J. Cabezas Corchero. (1996). "Sistemas de información: balance de 12 añps de jornadas y expectativas de futuro" Actas V Jornadas Españolas de Documentación Automatizadas. Universidad de Extremadura: Servicio de Publicaciones.

Borguiere, A. (2008). La escuela de los Annales. Valencia: Universidad de Valencia.

Bossuet, J. B. (1772). Discurso sobre la historia universal: para explicar la comunicación de la Religión, y las mudanzas de los imperios. Valencia: Imp. Benito Monfort. 
Brenneke, A. (1953). Archivkunde. Ein Beitrag zur Theorie und Geschichte des europäischen Archivwesens. Leipzig.

Casanova, E. (1928). "Storia degli archivi e dell'archivistita”. Archivística. Siena: Stab. Arti Grafiche Lazzeeri.

Echevarría, J. (1994). Telépolis. Barcelona: Ediciones Destino.

(1999). Los señores del aire: Telépolis y el tercer entorno. Barcelona: Ediciones Destino.

Hazard, P. (1935). La crisis de la conciencia europea 16801715. Madrid: Pegaso.

-_—— (1946). El pensamiento europeo del s. XVIII. Madrid: Alianza.

Lodolini, E. (1991). Lineamenti di storia dell'archivistica italiana. Dalle origini alla metà del secolo $\mathrm{xx}$. Roma: La Nuova Italia Scientica.

Lyotard, J. (1989). La condición postmoderna: informe sobre el saber. Barcelona: Cátedra.

Sandri, L. (1968). "La storia degli archivi". Actes du Viéme Congrès International des Archives. Archivum, 18.

Simiand, F. (1903) "Méthode historique et science sociale" Revue de Synthèse Historique, vol. 6, núm. 17, 129-157. Disponible en: <http://www.unige.ch/lettres/ enseignants/bmuller/textes0/Simiand/Simiand_RSH_ 1903_6_17> 
Uso ético de la información...

Simon, R. (1869). Histoire critique du Vieux Testament: la critique biblique au siècle de Louis XIV. Lausanne: Bridel. Disponible en: <https://archive.org/details/ richardsimonetso00bern>

Spinoza, B. (1670). Tractatus theologico-politicus. VII. Hamburgo.

Vivas Moreno, A. (2013). Breve historia cultural de la Archivística. Badajoz-Sevilla: Abecedario. 


\section{Anexos}

Tiempo 1.

\begin{tabular}{|l|}
\hline De la archivística empírica a la patrimonial y jurídico-administrativa \\
\hline Ciudad de Dios - Providencialismo. \\
\hline Paulatina construcción del individuo. \\
\hline Consolidación del Estado Moderno y afirmación de las monarquías absolutas. \\
\hline Archivos de Estado como archivos de poder. \\
\hline Factores macroestructurales: \\
- Práctica eclesiástica. \\
- Salvaguarda jurídica. \\
- Instrumentalización política. \\
- Burocracia. \\
\hline Evolución de una ética moral cristiana a una ética humanista y del individuo. \\
\hline Archivero: Funcionario conocedor de la administración. \\
\hline
\end{tabular}

Tiempo 2.

\begin{tabular}{|l|}
\hline \multicolumn{1}{|c|}{ Ciudad de los Hombres — Idea de Historicidad } \\
\hline El individuo como sujeto histórico. \\
\hline La identidad nacional. \\
\hline Archivos históricos y archivos nacionales. \\
\hline $\begin{array}{l}\text { Factores macroestructurales: } \\
\text { - Memoria histórica. }\end{array}$ \\
\hline De la ética del individuo a la ética colectiva. \\
\hline Archivero: Historiador. \\
\hline
\end{tabular}

Tiempo 3.

\begin{tabular}{|l|}
\hline \multicolumn{1}{|c|}{ Telépolis - Sociedad de la Información } \\
\hline Determinismo tecnológico. \\
\hline Transnacionalización. \\
\hline Archivos electrónicos. \\
\hline $\begin{array}{l}\text { Factores macroestructurales: } \\
\text { - La función informativa. }\end{array}$ \\
\hline Normatividad y códigos éticos. \\
\hline Archivero: Gestor documental. \\
\hline
\end{tabular}




\title{
Directrices para la elaboración de proyectos de inclusión digital
}

\author{
Sonia SÁNCHEZ CuAdrado \\ Facultad de Ciencias de la Documentación, \\ Universidad Complutense de Madrid, España
}

\section{INTRODUCCIÓN}

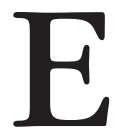
ste trabajo analiza los proyectos de inclusión digital desarrollados en el marco europeo, con el objetivo de definir las claves que determinen qué tecnología se debe usar en cada proyecto de inclusión digital. Este trabajo tiene su origen en la necesidad de identificar las soluciones tecnológicas aplicadas a la inclusión (Sanchez-Cuadrado et al., 2015).

La inclusión digital o la e-inclusion es promover la participación de los individuos dentro de la Sociedad de la Información a través del acceso a las Tecnologías de la Información y la Comunicación. El concepto e-inclusion comenzó a utilizarse a partir de 1999 cuando uno de los objetivos que se marcó Europa fue incluir a todos los ciudadanos en el contexto online con la mayor celeridad. Almuwil et al. (2011) recogen en su trabajo las iniciativas y estrategias que se han implementado en la Unión Europea desde entonces para promocionar la inclusión digital.

Los principales motivos de la exclusión digital son la pobreza, la falta de acceso tecnológico y la falta de competencias. Principalmente, estas causas se deben a factores económicos, socio-políticos y educativos. Las características del grupo de los afectados 
por la exclusión digital no pueden ser fijadas de modo general. Van Dijk (1999) fue uno de los autores que se pronunció sobre el aspecto multidimensional de la brecha digital en términos de superar cuatro barreras: acceso motivacional; acceso de material; acceso a las habilidades y acceso al uso. La e-exclusion puede estar condicionada porque se trata de un área sin acceso a Internet (intraestructure and connectivity), o porque no se puede disponer de ese servicio por cuestiones económicas como la adquisición de un ordenador, los gastos de servicio de Internet, etc. (affordability), o bien por la falta de competencias que requieren el uso del ordenador y la navegación en Internet (Illiteracy and capability). Otra posible causa frecuente de la exclusión digital se debe a la falta de motivación (motivation). Connectivity es la capacidad de conectase a Internet (Bradbook y Fisher, 2004). Affordability o asequibilidad es la cualidad que representa el coste asociado con la adquisición del hardware o software en términos de reducir y economizar las tasas (Bentivegna y Guerrieri, 2010). Capability o capacidad es la cualidad por la que se identifica el grado de la alfabetización, la habilidad y las competencias de los usuarios (Bradbook y Fisher, 2004). El concepto motivation o motivación, está relacionado con la actitud hacia la tecnología (Helsper, 2008; Verdegem y Verhoest, 2009).

La exclusión digital afecta a perfiles variados como jóvenes en riesgo de exclusión social, minorías étnicas, para ciudadanos mayores, inmigrantes, personas con algún tipo de discapacidad, etc., e incluso puede estar condicionada según el propósito. Por ejemplo, se ha planteado una clasificación para recoger las facetas que describieran la perspectiva individual de los ciudadanos para la inclusión digital del e-goverment: "demographic (age, marital status, race and ethnicity), economic (employment, income, urbanization), social (education, health, lifestyle), and cultural (language, knowledge, traditions)" (Almuwil et al., 2011).

En la Cumbre Mundial sobre la Sociedad de la Información del 2003 (World Summit Information Society) se propusieron unas líneas de acción para minimizar la desigualdad en el acceso a las Tecnologías de la Información y la Comunicación. 
La importancia de esta Cumbre y de estas líneas de acción se debe al compromiso de los países e instituciones públicas para presentar iniciativas, políticas y herramientas para minimizar la e-exclusion (ITU, 2013). Los proyectos para la inclusión digital se han basado en cada uno de estos planes de acción.

- La primera de esas líneas de acción (C1) se basa en el rol de los gobiernos y las partes interesadas para el desarrollo y la promoción de las TIC, lo que incluye las estrategias electrónicas nacionales, la reducción del uso del papel de las organizaciones y asociaciones internacionales.

- La segunda línea de acción (C2) se refiere a la importancia de la información y la infraestructura de la comunicación con respecto a la banda ancha, la conectividad para las instituciones de acceso público, la disponibilidad de equipos o servicios TIC suministrados por la cooperación internacional o regional.

- La tercera línea de acción (C3) propone trabajar en el acceso a la información y el conocimiento tratando aspectos relacionados con el acceso abierto, el acceso a la información, la legislación sobre la información, las bibliotecas y los centros comunitarios digitales.

- La cuarta línea de acción (C4) va dirigida a la formación para generar capacidad de creación cubriendo aspectos tales como la alfabetización en TIC, enseñanza a distancia, formación de profesionales para TIC e iniciativas de cooperación.

- La quinta línea (C5) de acción se centra en crear confianza y seguridad, por ejemplo con técnicas que permitan detectar el ciberdelito.

- La sexta línea (C6) se resume en crear un ambiente propicio.

- La séptima (C7) se centra en aplicaciones concretas de las TIC centradas en e-goverment, e-environment, e-learning, e-agriculture, etc.

- La octava línea de acción (c8) se dirige hacia la identidad y la diversidad cultural.

- La novena (C9) hacia los medios de comunicación, la libertad de prensa y la pluralidad en la información. 
- La decima línea de acción (C10) se dirige hacia las dimensiones éticas de la sociedad de la información. En concreto, incluye todas las iniciativas encaminadas a promocionar los valores de respeto, libertad, igualdad y solidaridad, así como la protección de los datos personales, privados y medidas preventivas contra los abusos de las TIC.

- La última (C11) se centra en la cooperación regional e internacional.

Fuera del panorama europeo, algunos países en vías de desarrollo trabajan en el acceso universal a las Tecnologías de la Información y la Comunicación, porque este aspecto se considera un indicador que proporciona estatus a la nación en relación con el acceso universal (Figueiredo et al., 2012), y se desarrollan como un medio para salir de la pobreza.

Dependiendo del país, se llevan a cabo proyectos de inclusión digital dirigidos a determinados perfiles. Por ejemplo, en Colombia el gobierno emprende diferentes estrategias que se destinan a minorías étnicas, discapacitados y a población con bajos recursos (González y Sánchez, 2013). En los países desarrollados como Australia, Bélgica, Hong Kong, Japón, Corea, Estados Unidos y Noruega aplican las tecnologías de la información y la comunicación a proyectos educativos relacionados con las competencias digitales en las escuelas (Hatlevik y Christophersen, 2013).

En el portal epractice.eu están disponibles los proyectos que constituyen casos de buenas prácticas contra la exclusión digital. Estos casos de buenas prácticas también son publicados en la revista europea de e-Practice en el European Journal of e-Practice que tiene como objetivo difundir los casos de éxito y buenas prácticas de inclusión digital (Wright y Wadhwa, 2010).

Las iniciativas publicadas referencian los casos de éxito, considerando que sus procedimientos pueden establecerse como buenas prácticas para colectivos concretos en proyectos de inclusión digital. Las buenas prácticas se definen como las directrices que han desempeñado un papel exitoso en una situación concreta, y por lo tanto sirven de solución para posibles contextos similares. 
Conviene que las buenas prácticas sean completamente transferibles, aunque en el caso concreto de la inclusión digital ciertamente es difícil que se dé, debido a la interrelación de los factores culturales, medioambientales y contextuales (Wright y Wadhwa, 2010).

Las aplicaciones generales para las que se trabaja la inclusión digital están dirigidas a principalmente a: $e$-healt, $e$-goverment, $e$ commerce, e-learning, e-enviroment, etc. No obstante, para que puedan tener éxito estas iniciativas, previamente se trabaja en la adquisición de las habilidades digitales, y en concreto en aquellos casos en los que los ciudadanos no poseen un determinado nivel de competencias, para después acometer proyectos adaptados a las habilidades de cada colectivo.

\section{Metodología}

En este estudio, se realiza un análisis sistemático de 35 proyectos y casos de éxito llevados a cabo en la Unión Europea con el objetivo de identificar los factores claves a considerar y extraer un conjunto de buenas prácticas que sean importantes para elaborar un proyecto de inclusión digital con éxito respecto a las tecnologías digitales adaptadas a cada grupo. Se tomó del portal epractice.eu los casos de buenas prácticas de e-inclusion sobre e-goverment y $e$-health. Los proyectos analizados son:

Tabla 1. Proyectos analizados y principales características.

\begin{tabular}{|l|l|l|}
\hline \multicolumn{1}{|c|}{ Proyecto } & \multicolumn{1}{|c|}{ Grupo } & \multicolumn{1}{c|}{ Enfoque } \\
\hline FINF0 & Inmigrantes & $\begin{array}{l}\text { - Portal web con información. } \\
\text { - Material formativo en 11 lenguas diferentes. } \\
\text { - Facilitar la integración de los llegados recientemente. }\end{array}$ \\
\hline Polonia.de & Inmigrantes & $\begin{array}{l}\text { - Portal dirigido a los polacos que viven en Alemania para } \\
\text { buscar y proporcionar información. }\end{array}$ \\
\hline $\begin{array}{l}\text { Stichting Maroc. } \\
\text { nl }\end{array}$ & $\begin{array}{l}\text { Jóvenes inmitar la integración de los llegados recientemente. } \\
\text { (tunecinos, argelinos, } \\
\text { libaneses, egipcios } \\
\text { marroquis). }\end{array}$ & $\begin{array}{l}\text { - Proporciona fórum, revistas, chatrooms, servicio de citas, } \\
\text { servicios religiosos, servicios de email. }\end{array}$ \\
\hline
\end{tabular}


Uso ético de la información...

Tabla 1. Proyectos analizados y principales características [cont.]

\begin{tabular}{|c|c|c|}
\hline Proyecto & Grupo & Enfoque \\
\hline TGD & Inmigrantes turcos & $\begin{array}{l}\text { - Canal de comunicación turco. } \\
\text { - También promoción de educación específica y programas de } \\
\text { formación. } \\
\text { - Facilitar la integración de los llegados recientemente. }\end{array}$ \\
\hline $\begin{array}{l}\text { Rete G2 seconde } \\
\text { generazioni }\end{array}$ & $\begin{array}{l}\text { Jóvenes de origen } \\
\text { extranjero y minorías } \\
\text { étnicas }\end{array}$ & $\begin{array}{l}\text { - Capacitación. } \\
\text { - Redes sociales, blogs y wikis. } \\
\text { - Diferentes idiomas. } \\
\text { - Promover la oferta cultural. }\end{array}$ \\
\hline XénoCLiPse & Minorías étnicas & $\begin{array}{l}\text { - Capacitación. } \\
\text { - Producir contenido digital. } \\
\text { - Alfabetización en recursos digitales. } \\
\text { - Promover la visibilidad y el reconocimiento de las minorías.. }\end{array}$ \\
\hline Rots\&Routes TV & Jóvenes inmigrantes & $\begin{array}{l}\text { - Capacitación } \\
\text { - Televisión web como periodistas, produciendo y creando } \\
\text { productos de cultura urbana y diversidad cultural. }\end{array}$ \\
\hline Bordergames & Jóvenes inmigrantes & $\begin{array}{l}\text { Cursos de animación 3D, edición de video, Photoshop, escribir } \\
\text { scripts, fotografía, habilidades sociales y dibujo, creación de } \\
\text { grupo, respeto a sí mismo y las organizaciones. }\end{array}$ \\
\hline ITpreneurs & $\begin{array}{l}\text { Herramientas de } \\
\text { aprendizaje para el } \\
\text { holandés }\end{array}$ & $\begin{array}{l}\text { - Adquisición de habilidades culturales y de otro idioma. } \\
\text { - Realidad virtual 3D (el barrio) para desarrollar habilidades } \\
\text { lingüísticas como empezar un diálogo con los vecinos, visita } \\
\text { virtual al banco, escuela, etc. }\end{array}$ \\
\hline $\begin{array}{l}\text { Alane Newsrea- } \\
\text { der }\end{array}$ & $\begin{array}{l}\text { Inmigrantes llegados } \\
\text { recientemente }\end{array}$ & $\begin{array}{l}\text { - Adquisición de habilidades culturales y de otro idioma. } \\
\text { - Análisis de feeds. }\end{array}$ \\
\hline NALDIC & Inmigrantes & $\begin{array}{l}\text { - Adquisición de habilidades culturales y de otro idioma. } \\
\text { - Desarrollar el currículum. } \\
\text { - Realizar videos para el canal de YouTube para enseñar inglés. }\end{array}$ \\
\hline AutreMonde & Inmigrantes & $\begin{array}{l}\text { - Combatir el analfabetismo. } \\
\text { - Acceso libre a computadoras. } \\
\text { - Formación básica en competencias digitales. } \\
\text { - Formación en aplicaciones de educación multimedia. }\end{array}$ \\
\hline DO ITI & $\begin{array}{l}\text { Mujeres desempleadas } \\
\text { inmigrantes }\end{array}$ & - Adquisición de competencias digitales. \\
\hline $\begin{array}{l}\text { Fundación Bip } \\
\text { Bip }\end{array}$ & $\begin{array}{l}\text { Minorías éticas y } \\
\text { grupos marginados }\end{array}$ & $\begin{array}{l}\text { - Adquisición de competencias digitales. } \\
\text { - Acceso. } \\
\text { - Formación. } \\
\text { - Proporcionar acceso equitativo a equipos con conexión a } \\
\text { Internet. } \\
\text { - Formación para la integración y la inserción laboral. }\end{array}$ \\
\hline
\end{tabular}




\section{Directrices para la elaboración de proyectos...}

Tabla 1. Proyectos analizados y principales características. [cont.]

\begin{tabular}{|c|c|c|}
\hline Proyecto & Grupo & Enfoque \\
\hline $\begin{array}{l}\text { Telnet } \\
\text { Foundation }\end{array}$ & $\begin{array}{l}\text { Niños en situación de } \\
\text { desventaja social }\end{array}$ & - Equipar a niños con computadoras y competencias digitales. \\
\hline $\begin{array}{l}\text { Bangladesh } \\
\text { Youth } \\
\text { Organization }\end{array}$ & Jóvenes inmigrantes & $\begin{array}{l}\text { - Adquisición de competencias digitales. } \\
\text { - Mejorar las competencias lingüísticas, competencias digitales } \\
\text { y preparar a los jóvenes en el mercado laboral. }\end{array}$ \\
\hline KEN & $\begin{array}{l}\text { Migrantes sin } \\
\text { cualficación reconocida }\end{array}$ & $\begin{array}{l}\text { - Impulsar el empleo. } \\
\text { - Aplicación para evaluar la cualificación de los migrantes sin } \\
\text { una cualificación reconocida en Alemania. }\end{array}$ \\
\hline NQOT & $\begin{array}{l}\text { Jóvenes universitarios } \\
\text { de áreas } \\
\text { desfavorecidas }\end{array}$ & $\begin{array}{l}\text { - Impulsar el empleo. } \\
\text { - Registro de CV en una base de datos para ser contratados por } \\
\text { compañías que se suscriban a la iniciativa. }\end{array}$ \\
\hline Arbete & Inmigrantes & $\begin{array}{l}\text { - Impulsar el empleo. } \\
\text { - Formación de inmigrantes en perfiles de trabajos especiales. } \\
\text { - Uso de móviles para enseñar el idioma. }\end{array}$ \\
\hline Studio+ & $\begin{array}{l}\text { Jóvenes sin } \\
\text { cualificación }\end{array}$ & $\begin{array}{l}\text { - Cualificar a los inmigrantes para empleos de las nuevas } \\
\text { tecnologías. } \\
\text { - Impulsar el empleo. } \\
\text { - Recursos musicales y gestión de eventos. }\end{array}$ \\
\hline Get-It & $\begin{array}{l}\text { Jóvenes desempleados } \\
\text { y graduados }\end{array}$ & $\begin{array}{l}\text { - Cualificar a los inmigrantes para empleos de las nuevas } \\
\text { tecnologías. } \\
\text { - Formación de su propio negocio. } \\
\text { - Utilizar las tecnologías de la información en sus negocios. }\end{array}$ \\
\hline FIT & Marginados & $\begin{array}{l}\text { - Cualificar a los inmigrantes para empleos de las nuevas } \\
\text { tecnololgías. } \\
\text { - Formación de competencias digitales. }\end{array}$ \\
\hline $\begin{array}{l}\text { IBM KidSmart } \\
\text { Early Learning } \\
\text { Program }\end{array}$ & $\begin{array}{l}\text { Niños de preescolar } \\
\text { con necesidades } \\
\text { especiales }\end{array}$ & $\begin{array}{l}\text { - Mejorar oportunidades de formación a niños inmigrantes } \\
\text { - Guías para padres y profesores. } \\
\text { - Acceso a KidSmart }\end{array}$ \\
\hline CH@VE & $\begin{array}{l}\text { Niños de primaria y sus } \\
\text { profesores }\end{array}$ & $\begin{array}{l}\text { - Mejorar oportunidades de formación a niños migrantes. } \\
\text { - Empleo de juegos para habilidades interpersonales. } \\
\text { - Competencias digitales y el uso de programas e-learning. }\end{array}$ \\
\hline Aula intercultural & $\begin{array}{l}\text { Profesores con } \\
\text { alumnos inmigrantes }\end{array}$ & $\begin{array}{l}\text { - Ayudar a los profesores de niños inmigrantes. } \\
\text { - Proporcionar material para manejar las relaciones } \\
\text { interculturales en la escuela. }\end{array}$ \\
\hline EMA & $\begin{array}{l}\text { Profesores de minorías } \\
\text { étnicas }\end{array}$ & $\begin{array}{l}\text { - Ayudar a los profesores de niños inmigrantes. } \\
\text { - Recursos en línea para profesores, alumnos y padres. } \\
\text { - Recursos para niños y jóvenes en Europa. }\end{array}$ \\
\hline
\end{tabular}


Uso ético de la información...

Tabla 1. Proyectos analizados y principales características. [cont.]

\begin{tabular}{|c|c|c|}
\hline Proyecto & Grupo & Enfoque \\
\hline CATIT & $\begin{array}{l}\text { Inmigrantes y minorías } \\
\text { étnicas }\end{array}$ & $\begin{array}{l}\text { - Ayudar a los profesores de niños inmigrantes. } \\
\text { - Formación de profesores y tutores. } \\
\text { - Elaboración de cursos en línea y materiales para el tutor. }\end{array}$ \\
\hline Innocent & Profesorado & $\begin{array}{l}\text { - Ayudar a los profesores de niños inmigrantes. } \\
\text { - Formación de profesorado para desarrollar habilidades de } \\
\text { gestión de interculturalidad, conflictos en la escuela, } \\
\text { eliminación de prejuicios, creación de espíritu multicultural. } \\
\text { - Difundir estrategias pedagógicas y metodológicas de } \\
\text { integración. }\end{array}$ \\
\hline $\begin{array}{l}\text { Learning Migra- } \\
\text { tion }\end{array}$ & $\begin{array}{l}\text { Profesores y directores } \\
\text { de escuela }\end{array}$ & $\begin{array}{l}\text { - Ayudar a los profesores de niños inmigrantes. } \\
\text { - Formación para profesores y directores de escuela, enfocada } \\
\text { a la multiculturalidad del aula. }\end{array}$ \\
\hline Race Equality & Profesores & $\begin{array}{l}\text { - Promover la educación intercultural. } \\
\text { - Herramienta contra el racismo. } \\
\text { - Fomentar la educación antirracista. }\end{array}$ \\
\hline ¡Respect & Profesores & $\begin{array}{l}\text { - Promover la educación intercultural. } \\
\text { - Servicios para promover la tolerancia positiva, la diversidad } \\
\text { cultural y la ciudadanía activa. } \\
\text { - Desarrollar historias. } \\
\text { - Libros multilingües. } \\
\text { - Funcionalidades de la web } 2.0 \text {. } \\
\text { - Recurso didáctico. }\end{array}$ \\
\hline BE-ME & Profesores & $\begin{array}{l}\text { - Promover la educación intercultural. } \\
\text { - Material audiovisual y paquetes de aprendizaje en línea } \\
\text { para aprender sobre la historia de los negros y las minorías } \\
\text { étnicas. }\end{array}$ \\
\hline $\begin{array}{l}\text { Didactic guide } \\
\text { for training ICT }\end{array}$ & & $\begin{array}{l}\text { - Promover la educación intercultural. } \\
\text { - Formación de competencias digitales. } \\
\text { - Planes de acción formativos para educadores. }\end{array}$ \\
\hline $\begin{array}{l}\text { La maleta inter- } \\
\text { cultural }\end{array}$ & Profesores & $\begin{array}{l}\text { - Promover la educación intercultural. } \\
\text { - Políticas y prácticas para la educación de ciudadanos. } \\
\text { - Recursos didácticos para la interculturalidad. }\end{array}$ \\
\hline ACODDEN & Profesores & - Promover la educación intercultural. \\
\hline
\end{tabular}

Fuente: Elaboración propia

Las principales características a tener en cuenta en los proyectos son: el perfil al que va dirigido; los factores que afecta a la falta de inclusión digital; y las soluciones tecnológicas que se van a implementar para evitar la e-exclusión. Por lo tanto, lo más importante 
a tener en consideración corresponde a que cada colectivo y cada ámbito precisan de una adaptación específica.

\section{IDENTIFICACIÓN DE PERFILES}

Tomando como base la clasificación de Almuwil et al. (2011) para definir la perspectiva del individual, y otras propuestas basadas en grupos vulnerables, se ha desarrollado una sistematización para clasificar el perfil al que se dirige. Esta clasificación se basa en cinco facetas: 1) condiciones mentales; 2) grupos de integración y asimilación; 3) edad; 4) situación económica; y 5) discapacidad física. Sin embargo al tratar de clasificar los proyectos se comprueba que la clasificación se adecuaba a vulnerabilidades evidentes en todos los contextos, pero detectamos carencias para definir perfiles comunes y afectados concretamente por el entorno digital.

Se comprueba la dificultad para clasificar la perspectiva individual o de grupo como una dimensión simple, pues consideramos necesario tener en cuenta diferentes condiciones permanentes o temporales que pueden afectar a las personas. Por eso, se recopila y sintetizan las variables que caracterizan la problemática del individuo excluido del entorno digital (Sánchez-Cuadrado et al., 2015), en concreto: 1) pobreza y países en desarrollo; 2) grupos étnicos e inmigrantes; 3) aislamiento; 4) discapacidad física; 5) discapacidad mental; 6) habilidades esenciales y formación; 7) habilidades interpersonales; y 8) escépticos o desmotivados.

En el Gráfico 1, que aparece en la siguiente página, se muestra la propuesta para caracterizar la perspectiva individual o de grupo como una dimensión multivariable (Sanchez-Cuadrado et al., 2015), donde se puede representar diferentes condiciones que pueden afectar al perfil de forma permanente o temporal. Las variables son valoradas según una escala de valores comprendidos entre 0 y 1 , siendo el 0 que no poseen esa característica y 1 que si la poseen. Los valores intermedios dan una proporción de en qué grado se ven afectados. 
Uso ético de la información...

Gráfico 1.

Aspectos para describir los contextos de los grupos a los que se dirige el proyecto.

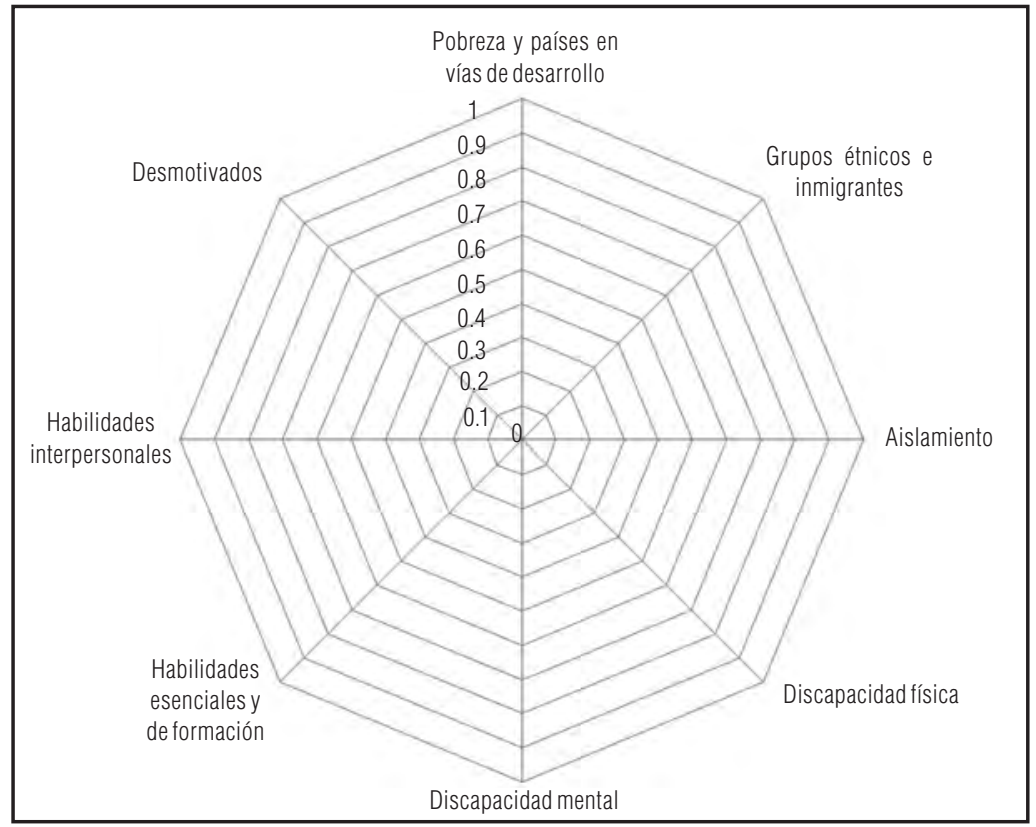

Fuente: Elaboración propia

\section{IDENTIFICACIÓN DE FACTORES Y TECNOLOGÍAS}

En general, la mayoría de los proyectos se basan en aplicar soluciones para los factores de connectivity, affordability y capability. Algunos autores han propuesto ampliar el tipo de factores para abordar la inclusión digital. Por ejemplo Wright y Wadhwa (2010) añadieron los factores de infraestructure, illiteracy, motivation, usefulness. Para estos factores también se pueden considerar múltiples dimensiones como access, usage, continuity, skills, attitude, y confidence (Almuwil et al., 2011).

En la línea de Almuwil et al. (2011) y para la identificación de factores a determinar en un proyecto de inclusión digital, en este estudio, se sintetiza en connectivity, affordability, capability, motivation, trust, y diversity en relación con las tecnologías aplicables 
en los proyectos de inclusión digital, y porque se entiende que con estos ya estarían cubiertos todos los referentes a los factores que afectan directamente a la tecnología. Los factores referentes a los usuarios se mostrarían en la caracterización del perfil. Una vez representados los factores en un gráfico radial, la comparación de las sombras permite la rápida evaluación de la situación de cada proyecto y la localización de iniciativas orientadas a objetivos similares. Los Gráficos 2 y 3 muestran ejemplos de representación de los factores que influyen en las iniciativas para la inclusión digital. Conectividad

Gráfico 2.

Ejemplo de la representación de los factores para la inclusión digital.

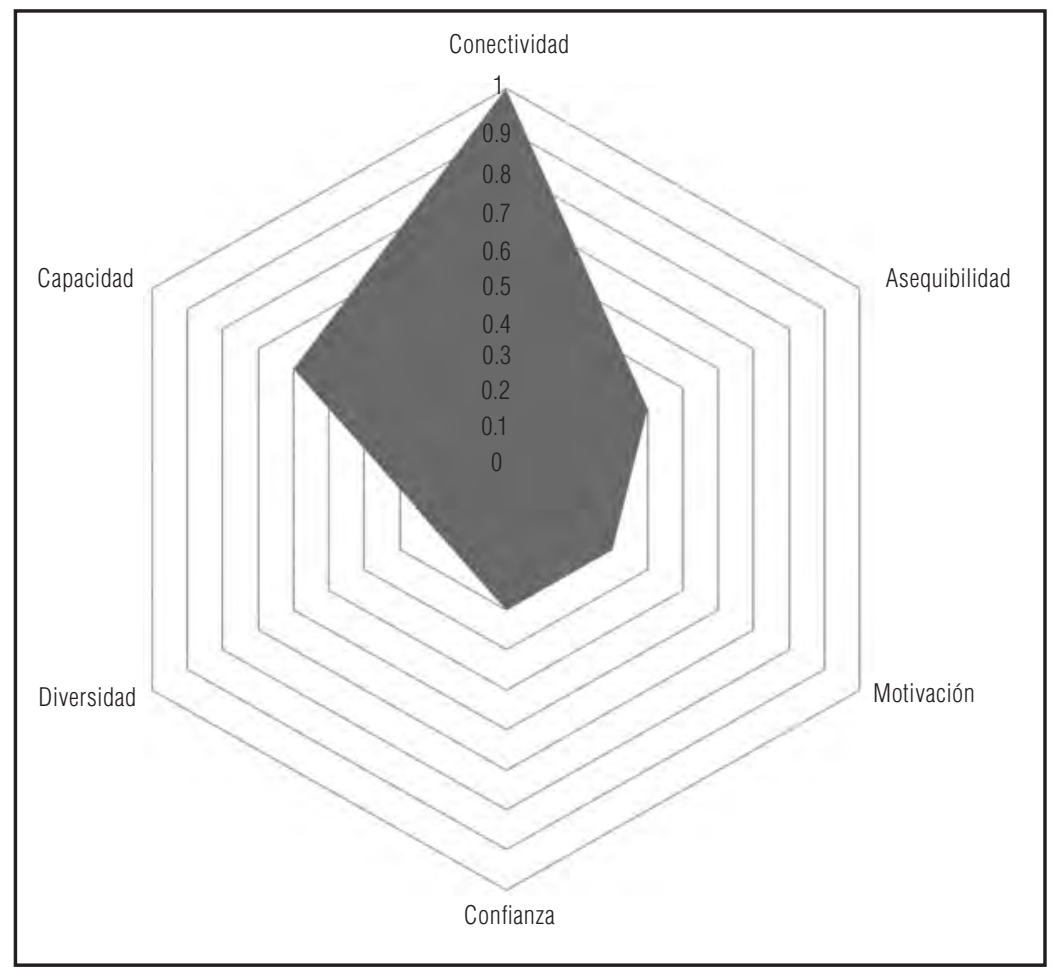

Fuente: Elaboración propia 
Gráfico 3.

Ejemplo de la representación de los factores para la inclusión digital.

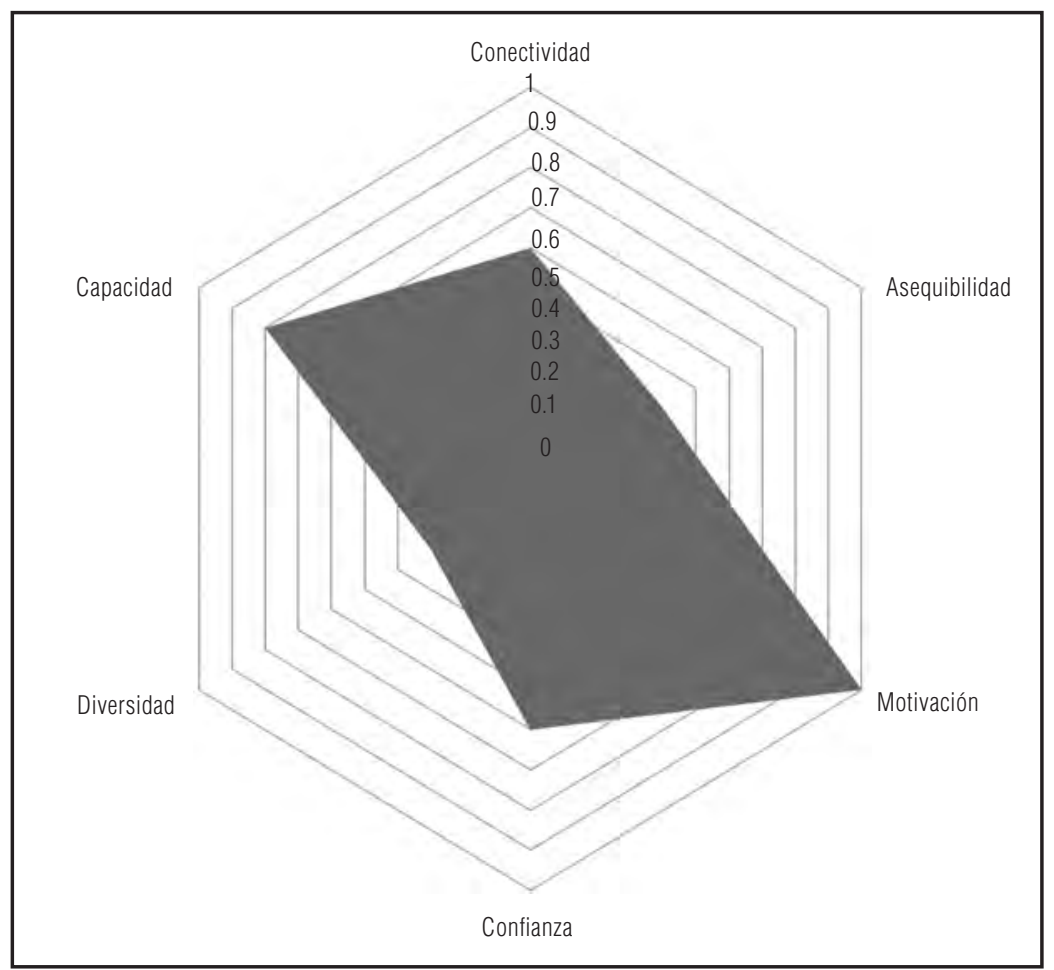

Fuente: Elaboración propia

Las estrategias asociadas a la conectividad y el acceso suelen estar vinculadas a las medidas políticas que implantan los gobiernos, por ejemplo para desarrollar y difundir la banda ancha para todos. También se adoptan proyectos de lugares Wi-Fi públicos ( $p u$ blic Wi-Fi hotspots) y despliegue de infraestructuras para la disposición de Internet móvil. En concreto, las tecnologías que se han localizado en relación a la conectividad son: disponibilidad de una 
computadora, disponibilidad de conexión a Internet, calidad de la conexión, Public Wi-Fi Hotspots e Internet móvil.

Observando los datos que proporciona la agenda digital (http:// digital-agenda-data.eu/) de la Comisión Europea, comprobamos que por lo que respecta a la conectividad y disponibilidad de infraestructuras, Europa está cubierta en más de un $80 \%$ de hogares con cobertura de banda ancha (Figura 1). Estos datos se ven condicionados por los datos significativamente inferiores que se obtienen de las zonas de baja densidad de población (Figura 2).

Figura 1. Cobertura de banda ancha en Europa.

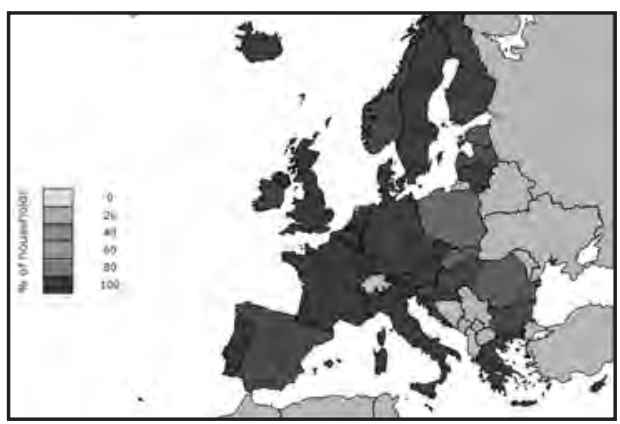

Fuente: Portal de datos abiertos de la Unión Europea [https://data.europa.eu]

Figura 2.

Cobertura de banda ancha en zonas de baja densidad de población en Europa.

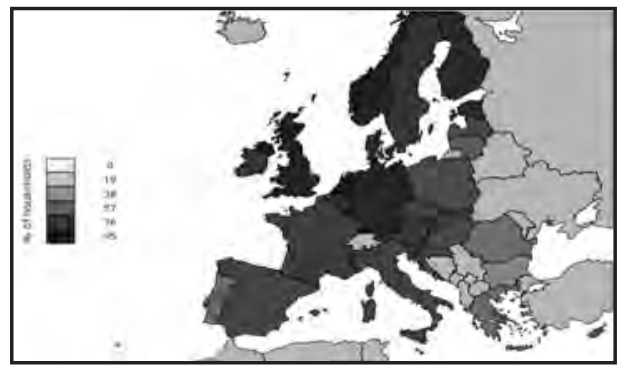

Fuente: Portal de datos abiertos de la Unión Europea [https://data.europa.eu] 
También es subrayable la disponibilidad de la cobertura en telefonía móvil 3G, destacando el dato sobre España cuando se interroga por los individuos que acceden a Internet a través de la telefonía móvil en los tres últimos meses). Estos porcentajes están en el mismo rango de uso que países como Suecia y Finlandia ( $F i$ guras 3 y 4 ).

Figura 3. Disponibilidad de la cobertura de telefonía móvil en Europa.

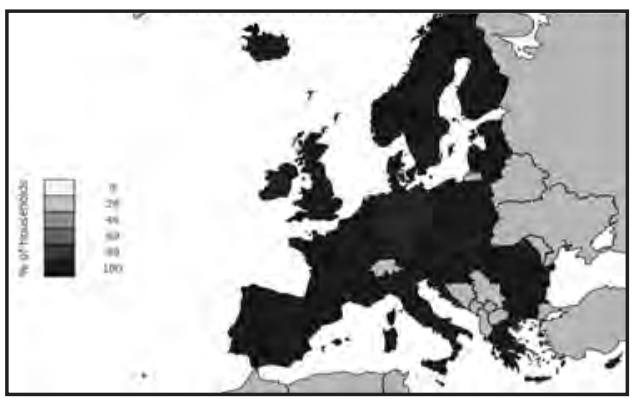

Fuente: Portal de datos abiertos de la Unión Europea [http://data.europa.eu]

Figura 4. Acceso a Internet a través de la telefonía móvil en los últimos tres meses.

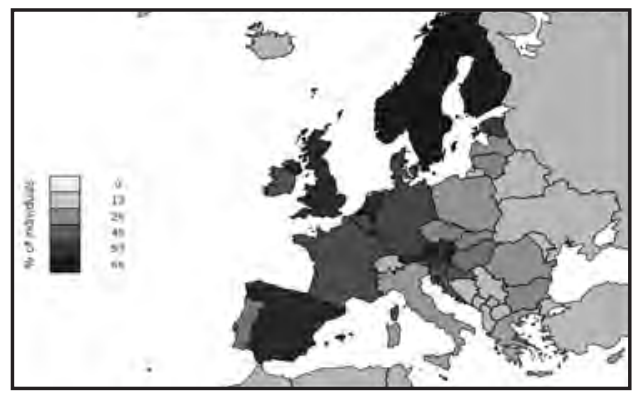

Fuente: Portal de datos abiertos de la Unión Europea [http://data.europa.eu]

\section{Asequibilidad}

La iniciativa más popular relacionada con affordability o la cualidad de hacer más asequible los productos digitales, probablemente sea el software libre, software gratuito, plataformas abiertas para la disposición pública, recursos proporcionados para todos 
con licencias abiertas, acceso abierto (share access), cloud computing. También están relacionados con este factor programas como one-laptop-per-child (también conocido por OLPC). En resumen este factor está caracterizado por tecnologías del tipo: iniciativas de software libre; préstamo de hardware; software gratis; plataformas abiertas; aprendizaje online abierto; share access; cloud computing y reducción de precios del hardware.

\section{Capacidad}

Capability o capacidad hace referencia a las habilidades y competencias de los usuarios. Estas habilidades y competencias se pueden ver condicionadas por la complejidad de los recursos o servicios, que a su vez varía según la percepción de los usuarios, normalmente dependiente de sus competencias digitales. La complejidad y por tanto, la falta de comprensión son algunas de las causas que provocan el rechazo de los servicios de e-goverment (European Commission, 2014). Esta complejidad o incomprensión para los usuarios se debe en muchas ocasiones a recursos complicados, confusos, o mal diseñados, aunque también a la propia capacidad del usuario en competencias de alfabetización. En capacitación, el número de tecnologías es bastante extenso: usabilidad, accesibilidad, capacidad para ser buscado, comprensibilidad, pantallas táctiles, asistentes, tecnologías 3D de visualización, búsqueda de información, búsqueda temas de interés, lecturas de noticias, chat, facilidad de consulta, creación de páginas web, creación de blogs, servicios de compra online, lupa, narrador, reconocimiento de voz y teclado en pantalla.

\section{Diversidad}

El factor de la diversidad (diversity) trata de tener en cuenta aspectos de pluralidad de modo que se contemple cada aspecto cultural y contribuyan a la inclusión con independencia de sus diferencias. Este factor de diversidad se encuentra en la línea de acción c8, donde se destaca la necesidad de desarrollar iniciativas y políticas para 
incentivar el respeto, la preservación y la promoción de la identidad lingüística y cultural. Esto significa que el diseño de los recursos tecnológicos y los sitios web deben estar planteados para los grupos a los que van dirigidos y tener en cuenta sus factores lingüísticos, culturales, tradiciones, o sus deficiencias. Esto mismo Thynyane y Tezoli (2009) lo diferencian en dos particularidades: context sensitive y knowledge centric. En la sensibilidad al contexto (context sensitive) tienen en cuenta el contexto a la hora de presentar la información, entendiendo por contexto la idiosincrasia cultural, las dinámicas sociales y los factores sociolingüísticos. En knowledge centric se valora el reconocimiento a la cultura, las tradiciones y la historia como componente básico para valorar el recurso. Los enfoques tecnológicos asociados a la diversidad son: desarrollo de arquitectura, accesibilidad web y software eye-gaze.

\section{Motivación}

Superadas las limitaciones en cuanto a competencias digitales, existen claras evidencias de que los usuarios también rechazan la tecnología, y con esto se evalúa la motivación (motivation). Uno de los motivos de ese rechazo podrían deberse al aspecto de continuity propuesto por Bradbrook y Fisher (2004) en el marco de las 5C (connection, capability, content, confidence y continuity), o en concreto a la falta de continuidad. Otra de los razones puede justificarse por la actitud (attitude) y que algunos autores la definen como la disposición hacia la tecnología (Helsper, 2008; Verdegem y Verhoest, 2009). La tecnología referida al factor de la motivación es: Fallos técnicos, Tiempo desmesurado de los procesos, complejidad del recurso, incompletitud del recurso, dificultad para completar los trámites, gamming, seguridad, calidad del recurso, realidad aumentada y videos.

\section{Fiabilidad y confianza}

También en relación con la seguridad y en concreto a la protección de los datos personales se relacionan factores como la fiabilidad y 
la confianza. Según el informe de eGoverment del 2014 (European Commission, 2014) la seguridad electrónica sólo está desarrollada en un $35 \%$ por lo que se trata de una implementación ciertamente escasa dada su importancia. Cuando se habla de fiabilidad y confianza (trust and confidence) nos referimos a: páginas seguras; cifrado; identificación; protección de datos personales; identificación de fuentes autenticas y compra segura.

\section{Resultados}

En este trabajo se confirma la utilidad de la clasificación de perfiles en: 1) pobreza y países en desarrollo; 2) grupos étnicos e inmigrantes; 3) aislamiento; 4) discapacidad física; 5) discapacidad mental; 6) habilidades esenciales y formación; 7) habilidades interpersonales; y 8) escépticos o desmotivados. Esta clasificación permite definir perfiles comunes y afectados concretamente por el entorno digital, y no sólo clasificar los grupos por algún tipo de vulnerabilidad evidente en cualquier contexto.

Se reafirma también el establecer 6 factores que afectan a los proyectos para la inclusión digital que se resume en: conectividad, asequibilidad, motivación, confianza, diversidad, y capacidad. Lo que permite representar la situación en un gráfico de tipo radial y posibilita la comparación rápida del contexto en el que se va a trabajar.

Se obtiene y proporciona un listado con las soluciones tecnológicas aplicadas en los desarrollos y proyectos recogidos como buenas prácticas. Una vez recopiladas las tecnologías por tipo de factor, observamos que aunque puedan ser asignadas a una categoría preferente, lo cierto es que esas tecnologías están condicionando al mismo tiempo a otros factores relacionados. Por ejemplo, la accesibilidad web afecta a la diversidad, ya que trata de que todos puedan acceder a un determinado recurso, pero también a cuestiones de capacidad y fiabilidad. A continuación, la Tabla 2 muestra los resultados de la relación entre tecnologías y tipos de factores. 
Uso ético de la información...

Tabla 2. Resultados de la relación entre tecnologías y tipos de factores.

\begin{tabular}{|c|c|c|c|c|c|c|}
\hline Tecnologías & Conectividad & Asequibilidad & Capacidad & Diversidad & Motivación & Fiabilidad \\
\hline Accesibilidad web & & & $\bullet$ & $\bullet$ & & $\bullet$ \\
\hline $\begin{array}{l}\text { Aprendizaje en plata- } \\
\text { formas abiertas en línea }\end{array}$ & & $\bullet$ & $\bullet$ & & & $\bullet$ \\
\hline Asistentes virtuales & & & - & & & \\
\hline $\begin{array}{l}\text { Búsqueda de informa- } \\
\text { ción }\end{array}$ & & & $\bullet$ & & & \\
\hline $\begin{array}{l}\text { Búsqueda de temas de } \\
\text { interés }\end{array}$ & & & $\bullet$ & $\bullet$ & $\bullet$ & \\
\hline Calidad de la conexión & $\bullet$ & $\bullet$ & & & & $\bullet$ \\
\hline Calidad del recurso & & & $\bullet$ & & $\bullet$ & $\bullet$ \\
\hline $\begin{array}{l}\text { Capacidad para ser } \\
\text { buscado }\end{array}$ & & & $\bullet$ & & & \\
\hline Chat & & & $\bullet$ & & $\bullet$ & \\
\hline Cloud computing & & - & - & & & \\
\hline $\begin{array}{l}\text { Complejidad del re- } \\
\text { curso }\end{array}$ & & & $\bullet$ & & $\bullet$ & $\bullet$ \\
\hline Comprensibilidad & & & $\bullet$ & & & \\
\hline Creación de blogs & & & - & & $\bullet$ & \\
\hline $\begin{array}{l}\text { Creación de páginas } \\
\text { web }\end{array}$ & & & • & & $\bullet$ & \\
\hline $\begin{array}{l}\text { Desarrollo de arquitec- } \\
\text { tura }\end{array}$ & & & & $\bullet$ & & \\
\hline $\begin{array}{l}\text { Dificultad para comple- } \\
\text { tar los trámites }\end{array}$ & & & $\bullet$ & & $\bullet$ & \\
\hline $\begin{array}{l}\text { Disponibilidad de co- } \\
\text { nexión a Internet }\end{array}$ & - & & & & & \\
\hline $\begin{array}{l}\text { Disponibilidad de un } \\
\text { libro electrónico }\end{array}$ & & $\bullet$ & $\bullet$ & & $\bullet$ & \\
\hline $\begin{array}{l}\text { Disponibilidad de una } \\
\text { computadora }\end{array}$ & $\bullet$ & & & & & - \\
\hline $\begin{array}{l}\text { Disponibilidad de un } \\
\text { smartphone }\end{array}$ & $\bullet$ & $\bullet$ & $\bullet$ & & $\bullet$ & \\
\hline $\begin{array}{l}\text { Disponibilidad de una } \\
\text { tablet }\end{array}$ & & $\bullet$ & $\bullet$ & & $\bullet$ & $\bullet$ \\
\hline Facilidad de consulta & & & - & & & \\
\hline
\end{tabular}


Directrices para la elaboración de proyectos...

Tabla 2. Resultados de la relación entre tecnologías y tipos de factores. [cont.]

\begin{tabular}{|c|c|c|c|c|c|c|}
\hline Tecnologías & Conectividad & Asequibilidad & Capacidad & Diversidad & Motivación & Fiabilidad \\
\hline Fallos técnicos & & & & & - & \\
\hline Gamming & & & - & - & - & \\
\hline $\begin{array}{l}\text { Incompletitud del re- } \\
\text { curso }\end{array}$ & & & & & $\bullet$ & \\
\hline Internet móvil & $\bullet$ & $\bullet$ & & & & \\
\hline Lectura de noticias & & & - & & • & \\
\hline Lupa & & & - & & - & \\
\hline Narrador & & & $\bullet$ & & • & \\
\hline Pantallas táctiles & & & $\bullet$ & & $\bullet$ & \\
\hline Plataformas abiertas & & $\bullet$ & & $\bullet$ & $\bullet$ & \\
\hline Préstamo de hardware & & $\bullet$ & & & & \\
\hline Public wi-fi hotspots & - & & & & & $\bullet$ \\
\hline Realidad aumentada & & & & $\bullet$ & $\bullet$ & \\
\hline Reconocimiento de voz & & & - & & • & \\
\hline $\begin{array}{l}\text { Reducción de precios } \\
\text { del hardware }\end{array}$ & & $\bullet$ & & & • & \\
\hline Seguridad & & & $\bullet$ & & $\bullet$ & \\
\hline $\begin{array}{l}\text { Servicios de compras } \\
\text { en línea }\end{array}$ & & & $\bullet$ & & & \\
\hline Share access & & $\bullet$ & & & & \\
\hline Software Eye-gaze & & & & - & $\bullet$ & \\
\hline $\begin{array}{l}\text { Software libre de re- } \\
\text { galías }\end{array}$ & & $\bullet$ & & & • & \\
\hline Software libre & & $\bullet$ & & & $\bullet$ & $\bullet$ \\
\hline Teclado en pantalla & & & - & $\bullet$ & - & \\
\hline $\begin{array}{l}\text { Tecnologías de la vi- } \\
\text { sualización }\end{array}$ & & & - & & • & \\
\hline $\begin{array}{l}\text { Tiempo desmesurado } \\
\text { de los procesos }\end{array}$ & & & & & $\bullet$ & \\
\hline Usabilidad & & & $\bullet$ & $\bullet$ & $\bullet$ & \\
\hline Videos & & & & $\bullet$ & - & \\
\hline
\end{tabular}

Fuente: Elaboración propia 
Contabilizando los datos de la tabla, se obtiene la proporción de las soluciones tecnológicas que proporciona o interviene cada factor. El Gráfico 4 muestra cómo el factor de la motivación con un $70 \%$ es el más trabajado en cuanto a la aplicación de tecnología, seguido de cerca del factor de la capacitación (68\%). En otro rango de valores encontramos en este orden de dedicación a los factores de asequibilidad (32\%), diversidad (25\%) y fiabilidad (23\%). Por último, observamos cómo el aspecto menos trabajado corresponde con la conectividad (16\%), datos que se justifican con la información que proporciona la Agenda Digital y que indican que Europa está bastante cubierta en cobertura de banda ancha.

Gráfico 4. Factores según la proporción de soluciones tecnológicas.

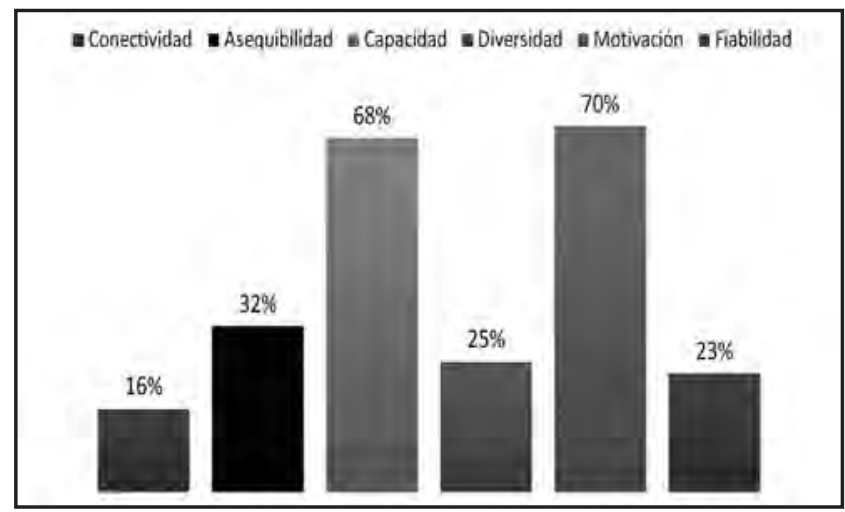

Fuente: Elaboración propia.

En cuanto a la dimensión ética de la Sociedad de la Información se incluyen todas aquellas iniciativas encaminadas a promocionar los valores de respeto, libertad, igualdad y solidaridad, así como la protección de los datos personales y privados, y las medidas preventivas contra los abusos de las TIC. Sin embargo, como se observa, aún queda lugar para trabajar en esta línea, puesto que en el gráfico anterior los factores donde se enmarca esta dimensión ética, diversidad y fiabilidad, están en cuanto a tecnologías en el 25 y $23 \%$ respectivamente. 


\section{Conclusiones}

La búsqueda de las claves para determinar qué tecnología usar en cada proyecto de inclusión digital ha permitido definir una clasificación de perfiles y factores que afectan a la exclusión digital. En la línea de este trabajo se ha establecido un método para representar la importancia relativa de las características a tener en cuenta en cada proyecto, la conectividad es uno de los factores básicos, de tal modo, que es lo primero que hay que asegurar en un proyecto. Para los proyectos de la Unión Europea, a excepción de sitios muy concretos o con restricciones específicas, se trata de un factor superado. Este método de representación de la situación de los proyectos proporciona un método rápido y eficaz de comparación de los contextos de las iniciativas. Esta técnica de cotejo proporciona una utilidad ética para la Sociedad de la Información, por cuanto permite la exposición clara y objetiva y la reutilización de la información. Por último, otra de las aportaciones relevantes de este estudio es la guía de soluciones tecnológicas asociadas a cada factor de exclusión.

\section{Bibliografía}

Almuwil, A., V. Weerakkody, y R. El-Haddadeh. (2011). A Conceptual Study of the Factors Influencing e-inclusion. Athens: Brunel University. Disponible en: <http://bura.brunel.ac.uk/handle/2438/8504>

Bentivegna, S. y P. Guerrieri. (2010). Analysis of e-Inclusion Impact Resulting from Advanced RED Based On Economic Modelling in Relation To Innovation Capacity, Capital Formation, Productivity, and Empowerment: A Composite Index to Measure Digital Inclusion in Europe. European Commission. 
Bradbrook, G. y J. Fisher. (2004). "Digital Equality Reviewing Digital Inclusion Activity and Mapping the Way Forwards". Citizens Online. Disponible en: $<$ www.citizensonline.org.uk/wp-content/uploads/939 _DigitalEquality1.pdf>

European Commission (2014). Delivering on the European Advantage? eGovernment Benchmark. Final Insight Report: May 2014. A Study Prepared for The Eurpean Commission DG Communications Networks, Contents and Technology. [s.1.]: Capgemini, IDC, Sogeti, IS-practice and Indogov, RAND Europe y Danish Technological Institute for the Directorate General for Communications Networks, Contents and Technology.

European Union Open Data Portal. http://data.europa.eu/

Figueiredo, M., P. Prado, y M. Kramer. (2012). "Overcoming poverty through digital inclusion". IT Professional, vol. 14, núm. 3, 6-10. Disponible en: <http://doi. ieeecomputersociety.org/10.1109/MITP.2012.57>

González Zabala, M. P. y M. Sánchez Torres. (2013). “Análisis de las estrategias del Gobierno colombiano para la inclusión de los ciudadanos en la Sociedad de la Información propuestas desde 2000 hasta 2011". Revista de estudios sociales, 47, 133-146.

Haché, A., J. Dekelver, L. Montandon, J. Playfoot, M. Aagaard y S. S. Elmer. (2010). Research and Policy Brief on ICT for the Inclusion of Youth at Risk: Using ICT to Reengage and Foster Socio-Economic Inclusion of Youth at Risk of Social Exclusion, Marginalized Young People and Intermediaries Working with Them. European Commission. 
Hatlevik, O. E. y K. A. Christophersen. (2013). "Digital Competence at The Beginning of Upper Secondary School: Identifying Factors Explaining Digital Inclusion". Computers E Education, vol. 63, 240-247.

Helsper, E. (2008). Digital Inclusion: An Analysis of Social Disadvantage and The Information Society. Department for Communities and Local Government.

ITU (2013). Report on the WSIS (World Summit on the Information Society) Stocktaking 2013. Geneve.

Sanchez-Cuadrado, S, A. Ruiz-Robles, J. Morato y M. Marzal. (2015). "Technologies for Digital Inclusion: Good Practices Dealing with Diversity". Handbook of Research on Comparative Approaches to the Digital Age Revolution in Europe and the Americas. Eds. Brasilina Passarelli, Joseph Straubhaar and Aurora Cuevas-Cerveró. Hershey, PA: IGI Global.

Thinyane, M. y A. Terzoli. (2009). "Universal digital inclusion: Beyond Connectivity, Affordability and Capability". Innovations for Digital Inclusions, K-IDI 2009. ITUT Kaleidoscope: IEEE.

Van Dijk, J. (1999). The Network Society. Social Aspects of New Media. Tousand Oaks. CA: Sage.

Verdegem, P. y P. Verhoest. (2009). "An User-oriented Policy for ICT Acceptance: The Relative Utility Approach". International Journal of public information systems, vol. 5, núm. 3, 179-189. Disponible en: <http://hdl. handle.net/1854/LU-764687>

Wright, D. y K. Wadhwa. (2010). "Mainstreaming the e-excluded in Europe: strategies, good practices and some ethical issues". Ethics and Information Technology, vol. 12, núm. 2, 139-156. Disponible en: <doi: 10.1007/ s10676-009-9213-y> 


\title{
Google scraping
}

\author{
Manuel BlázQuez Ochando \\ Universidad Complutense de Madrid, España
}

\section{INTRODUCCIÓN}

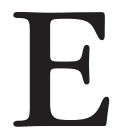

1 permanente crecimiento de la web y su indización en los principales buscadores ha propiciado un entorno documental de gran riqueza para los profesionales de la información. Debido a la magnitud y heterogeneidad del entorno, la extracción de contenidos relevantes se ha convertido en una tarea complicada, si no se disponen de las técnicas y métodos adecuados. Una solución a estos problemas es la minería de datos que consiste en la recolección sistemática de información procedente de documentos, páginas y sitios web estratégicos, que en origen podrían ser desconocidos para el investigador y que ayudan a formar nuevos conocimientos (Klösgen, W., y J. M. Zytkow, 2002).

Lamentablemente la minería de datos se basa en la asignación predeterminada de una serie de fuentes de información que serán el objetivo de los programas de rastreo. El investigador en todo caso condiciona la recopilación de datos con su conocimiento previo del entorno documental. Esto significa que sólo es posible recuperar una pequeña parte del todo a menos que el investigador indice Internet para discriminar qué fuentes de información especializadas son válidas y cuáles no. Esto origina diversas preguntas 
¿Es posible obtener la información de un área de conocimiento en la web usando técnicas de minería de datos? ¿Puede el investigador conocer todas las fuentes de información usando programas de tipo web crawler? Como se ha explicado, la minería de datos prospecta una serie de recursos conocidos, pero difícilmente puede localizar recursos que el investigador ignora.

Para descubrir toda la información publicada sobre un área de conocimiento, sería necesario rastrear todas las direcciones IP registradas en la ICANN ${ }^{1}$ e indizar sus contenidos para proceder a su filtrado posterior. Ésta tarea, del todo inasumible para la mayoría de investigadores, ${ }^{2}$ la desarrollan los buscadores globales de la Web. Por tanto resulta lógico pensar que se necesitan programas que faciliten la recopilación de datos en éstos buscadores. Con este enfoque se vienen desarrollando los programas de tipo SiteScraper (Penman, Baldwin y Martinez, 2009) cuya técnica sería conocida con la denominación web scraping para aludir al proceso de raspado, análisis y extracción de datos de un sitio web mediante patrones. ${ }^{3}$

El tema de web scraping sobre buscadores no ha sido muy profuso en la literatura científica excepto en patentes como se explicará a continuación. Si se realiza la consulta (scraping google o google scraping) en el buscador académico Google Scholar, se obtienen únicamente 51 resultados de los que sólo 2 están directamente relacionados con la recolección masiva de datos de los buscadores. Uno de ellos corresponde al libro de (Calishain y

1 Internet Corporation for Assigned Names and Numbers. Organización encargada de la gestión del redireccionamiento de las DNS Domain Name Server a las direcciones IP de los servidores web conectados a Internet.

2 Aunque los investigadores dispongan de programas web crawler capaces de rastrear millones de sitios web, no pueden asumir sin los medios adecuados, el análisis de todo Internet. Se necesita una infraestructura muy desarrollada con centenares de servidores y programas crawler recopilando contenidos y almacenándolos en forma óptima para su posterior indización, clasificación y recuperación.

3 XPath es el método de selección de nodos en un objeto DOM que almacena el código fuente de una página web. Esto permite crear patrones reconocibles como etiquetas y atributos propios del lenguaje de marcado HTML. 
Dornfest, 2003), titulado Google Hacks, que presenta el extinto API de Google para descargar sus páginas de resultados. La otra referencia corresponde al trabajo de (Ruecker y Devereux, 2004) en el que desarrollan un programa de webscraping para Google News.

Si se consulta (web scraping) como técnica aplicada a sitios y recursos en general, sin hacer mención a los buscadores, el número de resultados aumenta exponencialmente hasta las 1890 publicaciones científicas. Estos datos dan una idea de la importancia que tiene la técnica en el ámbito de las Ciencias de la Documentación. Algunas de las investigaciones más relevantes sobre web scraping tienen por objeto el desarrollo automático de la web semántica (Watson, 2009), la creación de webs sin intervención humana o autowebs (Thomsen et al., 2012), el desarrollo de modelos para compilar precios y comparar productos (Yibing, Zidong y Hongbo, 2014) o el análisis del discurso político de diversas fuentes de información (Hernández et al., 2015).

La literatura de patentes es muy destacada en torno al web scraping con más de 100 invenciones registradas sobre los procesos de descarga de contenidos de páginas web (Salerno y Boulware, 2006); la indización de textos por medio de scraping (Khan, 2012) y la protección de la información frente a esta técnica (Wetterström y Andersson, 2009).

\section{OBjeTO DE ESTUdio}

El objeto de la investigación es la experimentación de la técnica de web scraping en buscadores. En concreto se ha elegido el buscador Google por ser el más relevante y popular, así como su versión académica Google Scholar. Algunas de las razones que justifican su desarrollo son:

- Web scraping sobre buscadores es una forma de crear big data utilizando la principal fuente de información que indiza toda la web. 
- Podrían crearse scripts que permitieran rastrear los contenidos de los buscadores y generar bases de conocimiento especializadas.

- Los contenidos recuperados se podrían clasificar más fácilmente al ser devueltos con consultas compuestas por las palabras clave o descriptores.

- Uniendo la técnica de web crawler a la de web scraping se podrían rastrear sectores de la web desconocidos para los investigadores.

- Los contenidos recuperados mediante web scraping permitirían desarrollar buscadores más especializados con un bajo costo de desarrollo.

- Podrían crearse nuevas utilidades de comparación basadas en los resultados de los buscadores.

- Pueden elaborarse nuevos estudios métricos y alt-métricos a partir de los resultados proporcionados por los buscadores.

La investigación parte de la premisa de que los buscadores son la llave de acceso a la información publicada en Internet. Por tanto, sería lógico ser capaces de recuperar la información devuelta por los buscadores ante una serie de palabras clave, descriptores o consultas dirigidas por los investigadores. En consecuencia ¿sería posible extraer toda la información necesaria de un buscador? ¿Qué dificultades se podrían encontrar? ¿Qué técnicas o métodos pueden emplearse para descargar la información? ¿Qué dilemas o cuestiones éticas y legales plantearía el aprovechamiento masivo de datos en torno a un buscador?

\section{Metodología}

Una de las patentes con mayor impacto en el sector del web scraping (Nikovski y Esenther, 2008) lo define como el proceso de análisis de páginas web para la extracción de datos. El método comprende las siguientes etapas: 1) Descarga del código fuente de la página web para crear una plantilla DOM. Esto permite almacenar 
temporalmente el código HTML de la página y estructurar su contenido mediante nodos, identificados como etiquetas embebidas y jerarquizadas. 2) La etapa de selección de los nodos o elementos de la plantilla DOM, como por ejemplo las etiquetas de título, enlace o párrafo que contienen la información demandada. Esto se lleva a cabo mediante expresiones XPath con las que se construyen las rutas y sub-rutas de consulta. 3) Proceso de almacenamiento de la información para su posterior aprovechamiento. Éste método también pudo ser comprobado en la investigación sobre web spoofing (Blázquez, 2015) para el estudio del comportamiento de usuario.

El método para desarrollar el experimento de web scraping con Google se basa en las mismas etapas. Sin embargo, existen otras consideraciones que deben ser incluidas en el proceso. 1) Definición de la dirección URL de consulta del buscador e identificación de sus variables. Esto es conocer todos los elementos que componen un enlace para indicar aspectos como las fechas extremas de consulta, paginación, idioma, país y operadores especiales. 2) Identificación de estructuras de datos que contienen la información que se pretende recuperar. Consiste en el análisis de las etiquetas contenedoras y sus rasgos caracterizadores que faciliten un acceso unívoco y directo. Por ejemplo, las etiquetas que poseen un atributo con una denominación única o un valor común a los contenidos que se pretenden recuperar. La inspección de estos aspectos favorece el proceso de recopilación mediante XPath, ya que permite construir mejores rutas de acceso a los datos. 3) Etapa de descarga del código fuente. Cuando se trata de un sitio web generalista, la descarga del código no representa ninguna dificultad. Esto no sucede en el caso de los buscadores, ya que presentan limitaciones para programas de scraping y robots. De hecho las respuestas más frecuentes son el bloqueo de la página de resultados, la presentación de pruebas anti-robot y el bloqueo por dirección IP. Si bien las contramedidas de los buscadores pueden detener a la mayoría de los programas de web scraping, se pueden añadir alternativas que evaden los controles del buscador. Se trata del uso de recursos proxy que permitan enmascarar la dirección IP real por otra. 4) Comprobación de la integridad del código fuente y 
creación de la plantilla DOM. Como se indicó, este paso prepara la información contenida en el código para su recopilación. 5) Proceso de selección y extracción XPath mediante rutas de acceso a los elementos de la plantilla DOM. Se utilizan los rasgos diferenciadores que fueron identificados en el segundo paso. 6) Almacenamiento de los datos, tabulación y preparación para su representación. El método puede ser consultado en la Figura 1.

Figura 1. Proceso de web scraping en Google.

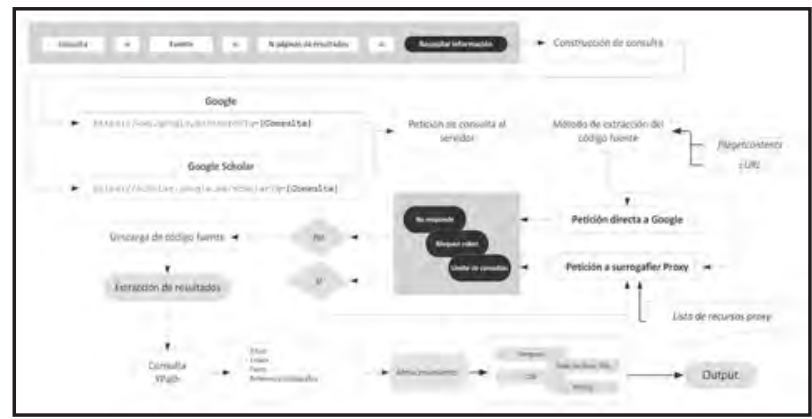

Fuente: <http://mblazquez.es/wp-content/uploads/google-scraping.png>

\section{Programa de scraping de Google}

El experimento de web scraping ha sido diseñado para descargar los contenidos más sustanciales, de las páginas de resultados de los buscadores Google y Google Scholar. Para ello ha sido creada una interfaz sencilla que está compuesta por una caja de consulta, un selector de buscador, un selector para activar la función de rastreo complementaria y otro para determinar el número de páginas de resultados sujetas a recopilación. El programa puede ser consultado para su verificación en la dirección <www.mblazquez.es/ google2down>

El programa ha sido sometido a pruebas de estrés para determinar el punto de ruptura del servicio del buscador Google, antes de ser aplicado el bloqueo preceptivo. En la mayoría de los casos, las consultas sencillas han permitido un máximo de 100 peticiones al servidor. Se pudo comprobar que según se aumen- 
ta la complejidad de las consultas con operadores intitle, intext, inurl, filetype, el buscador bloquea con mayor frecuencia las peticiones al servidor. Se puede afirmar que la sencillez de la consulta es directamente proporcional al número de peticiones que acepta Google. Cuanto más compleja sean las consultas, menos consultas por dirección IP permitirá el buscador. También implica mayor uso de los recursos de computación y resulta lógico que el acceso a consultas avanzadas automáticas sea más restringido. El bloqueo de los buscadores es resuelto mediante el enmascaramiento de la dirección IP y el uso de programas de tipo proxy. En este caso se usó el programa Surrogafier de Brad Cable (2015). Así cuando no se detectan resultados del buscador, el programa de web scraping transmite la petición de consulta al proxy, enmascarando el origen de la petición. Al no figurar la nueva dirección IP entre la lista de referencias bloqueadas, permite la recepción de la consulta y la consiguiente respuesta, descarga y extracción de sus datos. No obstante, el uso de un programa proxy no es garantía de funcionamiento permanente. De hecho Google puede detectar que las peticiones del proxy se desarrollan con una serie de direcciones IP específicas. Por ello el método óptimo consiste en disponer de una red de programas proxy que gestionen un rango importante de direcciones IP. De esta forma las direcciones comprometidas se desbloquean al cabo de 24 horas para volver a estar disponibles.

Figura 2. Impresión de pantalla del experimento de web scraping.

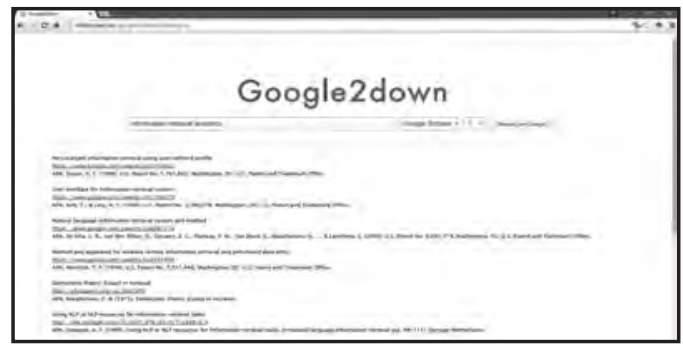

Fuente: Elaboración propia 
La selección de elementos de Google y Google Scholar es posible construyendo las rutas XPath que se muestran en la Tabla 1. Pueden observarse algunos elementos distintivos como los atributos class $=s t, i d=g s \_c i t O, \mathrm{i} d=g s \_c i t 1, i d=g s \_c i t 2$ que permiten recuperar la cita textual de los resultados, su referencia bibliográfica en formato APA, ISO y MLA.

Tabla 1.

Rutas XPath para la selección de resultados en Google y Google Scholar.

- Título

Web scraping en Google

\$xpath11->query("//h3/a[contains(@href,'/url')]")->item(\$i11)->nodeValue;

$\cdot$ Enlace

\$xpath11->query("//h3/a[contains(@href,'/url')]/@href")->item(\$i11)->nodeValue;

- Texto

\$xpath11->query("//span[@class='st']")->item(\$i11)->nodeValue;

· Título Web scraping en Google Scholar
\$xpath11->query("//h3/a")->item(\$i11)->nodeValue;
$\cdot$ Enlace
\$i11tem_link=\$xpath11->query("//h3/a/@href")->item(\$111)->nodeValue;
$\cdot$ Referencia APA
\$xpath22->query("//div[@id='gs_cit0']")->item(\$i22)->nodeValue;
• Referencia IS0
\$xpath22->query("//div[@id='gs_cit1']")->item(\$i22)->nodeValue;
-Referencia MLA
\$xpath22->query("//div[@id='gs_cit2']")->item(\$i22)->nodeValue;

Fuente: Elaboración propia

Otro aspecto probado es la función de rastreo secundario de los resultados. Los enlaces recopilados son procesados mediante web crawler. En este caso se utiliza el código del programa $M b o t$ (Blázquez, M. 2013). Este método amplía la información de los resultados obtenidos por el buscador, ya que permite rastrear todos 
sus enlaces, recursos y texto completo. Esto significa que es posible crear nuevos buscadores basados en los ya existentes. En la Figura 3 se observa cómo los resultados pueden ser analizados a voluntad por el usuario, obteniendo el texto indexable y los enlaces recuperados.

Figura 3.

Función de rastreo de resultados desde el programa de scraping.

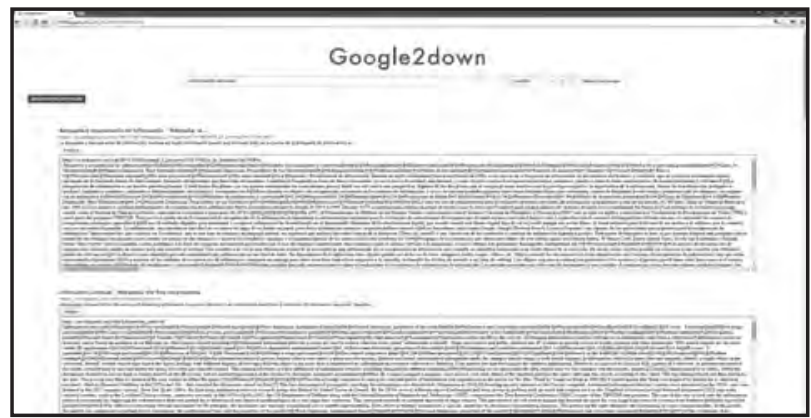

Fuente: Elaboración propia

\section{Conclusiones}

El experimento demuestra que es posible usar técnicas de web scraping en buscadores y descargar la información que se necesite para componer una nueva base de conocimiento.

Las limitaciones del web scraping surgen cuando se desea recopilar cantidades masivas de datos. Los buscadores identifican el equipo que está realizando las descargas de contenidos y bloquean su trabajo mediante medidas de seguridad captcha que deben ser desbloqueadas manualmente, o bien, añadiendo la dirección IP del usuario en la lista negra de accesos no autorizados.

Las medidas de seguridad que presentan los buscadores son evitables, tal como queda demostrado en la investigación, siempre que se usen listas de servidores proxy que logren enmascarar o cambiar la dirección IP del usuario. De esta forma, cuando una dirección IP queda bloqueada, los programas de scraping pueden usar un proxy para continuar el trabajo de descarga. 
La técnica de web scraping en el ámbito de la documentación permite abrir una nueva vía para la investigación. La creación de bases de conocimiento especializadas de forma automática, la recuperación y clasificación masiva de contenidos disponibles en la Web, la vigilancia informacional de alcance global, la creación de nuevos buscadores súper-especializados, la creación de big data en cualquier área de conocimiento y propósito son algunos ejemplos de aplicación que pueden esperarse del empleo de éstas técnicas.

\section{Discusión, uso ético de la información: implicaciones y} desafíos

Las aplicaciones del web scraping orientado a buscadores son muy prometedoras desde un punto de vista científico, tecnológico, social y económico, pero también es cierto que plantea diversos dilemas éticos. Por una parte el acceso a la información pública en la web es libre y resulta un argumento fuerte en favor de poder descargar los contenidos desde un buscador. Pero por otra parte, la tecnología y los medios necesarios para indexar y dar acceso a los miles de millones de sitios web, no son gratuitos. Son el resultado de un negocio basado en la recuperación de información y la publicidad. Por tanto cabe preguntarse ¿hasta qué punto podrían ser empleadas las técnicas de web scraping para generar nuevos productos basados en la recuperación de información?

Parece lógico que la aplicación científica del web scraping no debería perjudicar a los principales buscadores, ya que el propósito principal es la ampliación del conocimiento en beneficio de la sociedad y de la propia ciencia. Sin embargo si se diera el caso de copiar la información de los buscadores para competir con ellos bajo otra marca, se produciría un caso sin precedentes. Debe tenerse en cuenta que las direcciones de los sitios web son públicas y de libre acceso. Para acceder a ellas se utilizan los servicios de recuperación de un buscador de acceso abierto y cuyos resultados son descargados mediante web scraping. El resultado de las descargas masivas es la conformación de una nueva base de conocimiento para un nuevo producto o servicio. Para complicar aún más la 
trama, puede afirmarse que copiar o referenciar los enlaces de las páginas de resultados de un buscador no es un acto delictivo por sí solo. Esto se debe a que es, en esencia, la misma tarea que desarrollan los buscadores cuando rastrean la web.

En relación a las cuestiones socio-económicas que podrían derivarse de la técnica de web scraping, un ejemplo claro corresponde a los buscadores de comparación de productos y servicios. Son programas especializados en la selección de sitios y páginas web de las que extraen información precisa con la que operan sus comparativas. Pero, qué ocurriría si se descargara un sector específico de la web a través de un buscador, para crear un producto de información, y posteriormente se comercializara ¿Sería reprobable el uso de buscadores para crear el producto? ¿Sería positivo por abrir nuevos mercados y crear puestos de trabajo?

La información publicada en Internet es cada vez más accesible como consecuencia del uso de buscadores y técnicas basadas en crawling y scraping. En la práctica puede afirmarse que los contenidos que no están protegidos en redes privadas son de acceso y dominio público. Esto plantea nuevos interrogantes y obliga a la comunidad científica a pensar en formas más sencillas y efectivas de proteger la información, pero también de abrir Internet al libre desarrollo de tecnologías de scraping como un subsector más de la industria.

El futuro del web scraping y el big data están directamente vinculados al profesional de la información y en particular a la figura del documentalista. Tareas como la selección de los datos, su procesamiento, almacenamiento, tabulación y análisis deberán ser dominadas para lograr una inteligencia competitiva más eficaz, crear nuevos servicios y productos de información que ayuden a dinamizar la economía y la sociedad. 


\section{BibliografíA}

Blázquez, M. (2013). "Desarrollo tecnológico y documental del webcrawler Mbot: prueba de análisis Web de la universidad española". XIII Jornadas Españolas de Documentación FESABID. (23-25 mayo).

-_- (2015). "Técnica de suplantación de páginas web para el estudio de la usabilidad y experiencia de usuario: metodología y estudio de caso". VII Encuentro EDICIC. (16-17 noviembre).

Cable, B. (2015) Surrogafier. Disponible en: <https:// github.com/BCable/surrogafier>

Calishain, T., y Dornfest, R. (2003). Google Hacks. O'Reilly Media.

Hernández, A. T., E. G. Vázquez, C. A. B. Rincón, J. M. García, A. C. Maldonado y R. I. Orozco. (2015) "Metodologías para análisis político utilizando Web Scraping”. Research in Computing Science, vol. 95, 113-121.

Khan, S. (2012). U.S. Patent Application No. 13/485,703. Disponible en: <https://www.google.com/patents/ US20120310914>

Klösgen, W. y J. M. Zytkow. (2002). Handbook of Data Mining and Knowledge Discovery. Oxford University Press, Inc.

Nikovski, D. N. y A. W. Esenther. (2008). U.S. Patent Application No. 12/239,859. Disponible en: <https://www. google.com/patents/US20100083095> 
Penman, R. B., T. Baldwin y D. Martinez. (2009). Web Scraping Made Simple with Sitescraper.

Ruecker, S. y Z. Devereux. (2004). "Scraping Google and Blogstreet for Just-in-Time Text Analysis". CaSTA-04, The Face of Text, Ontario: McMaster University.

Salerno, J. J. y D. M. Boulware. (2006). U.S. Patent No. 7,072,890. Washington, DC: U.S. Patent and Trademark Office. Disponible en: <www.google.com/patents/ US7072890>

Thomsen, J. G., E. Ernst, C. Brabrand y M. Schwartzbach. (2012). "Webself: A Web Scraping Framework". Web Engineering. Springer Berlin Heidelberg.

Watson, M. (2009). "Using Web Scraping to Create Semantic Relations. Scripting Intelligence: Web 3.0". Information Gathering and Processing, 205-228.

Wetterström, R. y S. Andersson. (2009). U.S. Patent Application No. 13/000,157. Disponible en: <www.google.es/ patents/US20110185434>

Yibing, S., Z. Zidong, y L. Hongbo. (2014). "A Model of Compiling Price Index Based on the Web Scraping Technology". Statistical Research, vol. 10, núm. 15. 


\title{
La interacción entre los investigadores y la biblioteca para estimular conductas éticas y evitar plagios en las publicaciones académicas
}

\author{
Estela Morales Campos \\ Instituto de Investigaciones Bibliotecológicas y de la Información, \\ Universidad Nacional Autónoma de México, México
}

\section{INTRODUCCIÓN}

9 n las últimas décadas varias páginas de diarios y revistas no especializadas, así como espacios digitales, han dado cuenta de casos de plagio de textos literarios y académicos de todas las áreas y de tesis de licenciatura y de posgrado. Las opciones digitales como las redes sociales con miles de seguidores, o los blogs, han reseñado paso a paso plagios de autores reconocidos y de académicos distinguidos, actualizando periódicamente la información con nuevos datos e imágenes escandalosas, que mantienen el interés y la curiosidad, lo cual recuerda la moda del siglo XIX de las novelas por entrega. Esta situación, si bien no es nueva, en la actualidad, con las TIC, le da una nueva dimensión a la denuncia de estos hechos y permite una visibilidad masiva a conductas ilícitas de creadores, investigadores y autores de todo tipo; unos reconocidos en su campo y por la opinión pública, otros de incipiente trayectoria.

El plagio, el robo de ideas ya registradas con anterioridad, la usurpación de autoría total o parcial, han existido desde que se generaron los primeros textos y se dejó constancia registrada de los saberes, conocimientos, deseos y emociones de individuos y 
comunidades; el conocimiento social de estos robos tardaba en descubrirse y darse a conocer; sin embargo, se dejaba constancia de la anomalía y la irregularidad; y así sabemos de obras apócrifas, versiones no autorizadas, alteración de datos, o claros plagios, sólo que en el pasado, las tecnologías y los medios de comunicación no eran tan rápidos ni facilitaban la detección de textos copiados de alguno anterior. Un especialista o conocedor de un asunto específico puede detectar y reconocer el tema en cuestión, y de ahí iniciar una investigación casi policiaca para aclarar la ruta del robo, desde el producto detectado hasta su origen. Esta investigación detectivesca ha sido una práctica cotidiana de la que pueden dar fe nuestras bibliotecas. En la actualidad, la evolución de las TIC hace que muchos procesos de detección se faciliten y pongan a nuestro alcance ayudas de una manera global y universal

Cuando se analiza o se está cerca de un hecho de plagio, de incumplimiento al derecho de autor o ante la falta de integridad académica de un colega, tendría que preguntarse cuántos actores intervienen en el hecho ilícito de manera central o colateral, de forma premeditada o por ignorancia, por descuido o por abuso. Para las bibliotecas y los especialistas de la información es muy importante conocer el fenómeno, los actores participantes, los marcos normativos institucionales, la legislación nacional e internacional; en este caso sobre propiedad intelectual y derechos de autor, porque en cada una de las fases del proceso de creaciónplagio-detección el bibliotecario puede y debe participar; aportar conocimientos, información, técnicas y uso de tecnologías que ayudarán y facilitarán la detección del plagio y, sobre todo, la prevención del ilícito o la mala o equivocada conducta científica y fomentar una cultura de respeto al otro y a las obras de otros y dar seguimiento a la integridad académica.

\section{Del PROYECTO DE INVESTIGACiÓN A LA PUBLICACIÓN}

El acto ilegal o falta de ética en el proceso de investigación puede germinarse desde la concepción del proyecto o en alguna de sus 
fases posteriores: en el planteamiento de la hipótesis, que pretenderá probar algo que no está probado o que no existe evidencia. Posteriormente, dependiendo de la metodología, se irá desarrollando todo el proceso que se requiere, ya sea en el laboratorio o en el trabajo de campo. Las ciencias sociales, y aun las humanidades, hacen mucho trabajo de campo, de manera formal o con la simple interacción con la sociedad, con un pequeño grupo, que es parte del proyecto como sujeto de estudio, o lamentablemente, a veces lo toman como objeto de estudio. Y en todo este proceso hay preguntas sobre si el trabajo ya se realizó con anterioridad, o si la interacción con los seres vivos que intervienen, o a los que se intervienen se tratan con el respeto y el cuidado que marca la ética de investigación y profesional.

En toda esta etapa, el bibliotecario debería estar presente guiando, apoyando al grupo de investigación, verificando en fuentes específicas que den fe a otras investigaciones parecidas de sus resultados, o bien, después de una búsqueda exhaustiva, se compruebe la originalidad de la idea y las correlaciones que se puedan encontrar entre los pares del universo temático de que se trate.

Una vez concluida la investigación y obtenidos los resultados esperados, positivos o negativos, se procederá a realizar el reporte final o concluirlo, si es que se hicieron reportes y/o publicaciones parciales. En la etapa de publicación, la biblioteca y el bibliotecario son auxiliares de primer orden para el equipo de investigación ya que pueden responder muchas preguntas a los redactores, orientarlos acerca de cómo deben citarse las obras consultadas, aquellas que fueran antecedentes o proveedoras de información fundamental para la investigación en curso, así como reconocer a todos los participantes en el proceso académico y dejar constancia de los apoyos, de los grupos de experimentación o de estudio. En la medida en que se asienten los créditos debidos y de forma correcta (utilizando normas internacionales aprobadas por los grupos disciplinarios), se evitarán dudas sobre la autoría académica legalmente reconocida.

También resulta muy útil el entrenamiento para la redacción de reportes y artículos científicos, que debería incluir no sólo el estilo 
de redacción sino temas relativos a los créditos, de texto, de gráficos, de datos; la citación, la verificación y la comparación de textos similares (Roig, 2015). Este entrenamiento en redacción de textos se puede enriquecer con un ejercicio complementario y colectivo de escritura y lectura crítica de textos; la lectura es muy útil porque permite ejercer la crítica y valorar la claridad de las ideas.

Una instancia idónea para organizar estos talleres es la biblioteca, y un actor convocante natural es el bibliotecario, quien puede ofrecer el soporte informativo, una amplia gama de softwares y las TIC para apoyar este entrenamiento.

Durante el proceso de investigación se debe verificar cada paso y cada resultado, para que nada haya sido alterado, copiado, o manipulado; pero durante la etapa de redacción de los resultados de un artículo, de un libro es el momento en el que se debe hacer el análisis final del cumplimiento con los principios éticos establecidos por la disciplina, la institución y el grupo de trabajo. Si en el proceso de la investigación es útil la participación del bibliotecario, en el proceso de publicación su apoyo será fundamental por la relación con los formatos establecidos por la editorial, las citas y la verificación de los datos. Una vez publicado el texto, el bibliotecario debe apoyar y colocar ese registro de investigación en los circuitos internacionales y de pares más adecuados y relevantes para que tenga visibilidad, y entre en el circuito internacional de las citaciones para que posteriormente, sea contabilizado en los rankings.

La relación entre la institución y la revista académica debe ser fluida y transparente a fin de propiciar una cultura institucional de respeto a la creación del otro, a prácticas éticas de investigación y publicación (Wager, 2015).

Un marco normativo que ayuda a promover la integridad académica que se refleja en la publicación de resultados es el trabajo del Committe on Publication Ethics (COPE) y la guía que ha generado: Cooperation between Research Institutions and Journals on Research Integrity Cases (Mah 2015). 


\section{LOS DIFERENTES ACTORES QUE PARTICIPAN EN EL PROCESO}

Hasta ahora se ha destacado la participación de los investigadores y lo propicio que sería que se incluyera al bibliotecario, pero el equipo que hace posible un proyecto de investigación debe estar mencionado de forma explícita, institucional, autofinanciable, con fondos gubernamentales o con el patrocinio de una institución oficial o privada, es amplio, multidisciplinario y muy deseable que sea plural.

Desde que se concibe la idea de una investigación o de un proceso de creación, y se obtiene el visto bueno para iniciar el trabajo, o se toma la decisión de hacer realidad una inspiración y un proceso creativo, el dueño de esa nueva idea debe haber verificado que realmente sea nueva y original; de manera simultánea debe llevar una bitácora o lista de los requerimientos del proyecto y de todas las personas e instancias que participarán, así como sus responsabilidades. En esta fase se tiene que ser muy claro de quiénes serán reconocidos como autores, coautores, o participantes con los que, de alguna forma, se hace el compromiso de darle crédito en la publicación.

Todos los actores relacionados deben ser advertidos de los compromisos que adquieren con el respeto a ciertos principios éticos y legales, que permitirán evitar prácticas negativas en la investigación y la creación, como la falta de integridad del equipo, copia o alteración dolosa de datos o procesos a los que no se les da crédito o no se transparentan.

Entre los varios actores que pueden enlistarse están: los autores-creadores (que incluye a todo el equipo de trabajo que se considere responsable del producto), los estudiantes, los tesistas, los becarios (este grupo de colaboradores son un tema delicado ante el que se debe ser muy claro en cuanto a derechos y obligaciones), los evaluadores de los resultados (comités científicos, pares académicos), los editores (que a su vez pueden ejercer otra evaluación). Una vez publicado (hecho público), participará el lector-usuario (como individuo o como comunidad científica, cultural, social), el librero, el bibliotecario y los especialistas digitales, para promover 
y dar visibilidad por varios medios, incluyendo las actuales TIC (D'Agostino, 2015; Brown y Waelde, 2015).

La definición de la autoría y los diferentes niveles de participación son cruciales a fin de evitar confusiones y falsas expectativas, así como la aceptación de compromisos de trabajo con integridad y con respeto a las normas institucionales y legales que rigen el derecho de autor y el respeto al trabajo de otro o de otros (Koepseell y Ruíz de Chávez, 2015).

La publicación es la presentación pública de los resultados de un proyecto de investigación o de un proceso creativo y se espera que ésta sea verídica, transparente, que los datos sean tan claros que permitan replicar y/o probar los resultados. La publicación se ha vuelto muy importante como prueba de resultados, de trabajo; es el elemento definitorio en una evaluación académica en todas las ciencias físicas, las biológicas, las sociales, las humanas. La autoría en una publicación da estatus, prestigio, honores, que se puede traducir en avances profesionales y económicos (Koepsell y Ruíz de Chávez, 2015).

Entre todos estos actores debería estar integrado el bibliotecario, no para tener una autoría, sino como parte de las instancias de apoyo académico que tiene una institución para facilitar el trabajo de investigación. La biblioteca y los bibliotecarios enriquecerán el trabajo del equipo académico verificando toda información que se requiera en el proceso, además de dar los elementos que se vuelven parte de un artículo, una publicación; por ello, también será útil su trabajo con los evaluadores y los editores, al proporcionar tanto la información como el manejo de software y otras TIC que permita encontrar similitudes con otros textos publicados con anterioridad. El trabajo del bibliotecario evitará repetir tareas y problemas de transparencia en el proceso de investigación y de edición; y en algunos casos graves y extremos, demandas legales por faltas al derecho de autor y a la propiedad intelectual. 


\section{LA INTEGRIDAD ACADÉMICA EN LA INVESTIGACIÓN Y LA BIBLIOTECA}

Normalmente cuando surge la preocupación y se dedica la atención y esfuerzos a las faltas éticas en la investigación o a las publicaciones es porque algún lector ha denunciado alguna duda sobre la originalidad total o parcial de un artículo o un reporte; ya sea que lo denuncie ante la academia o ante algún medio público y masivo, como la prensa, el internet, una página web o un blog. Cuando se hace la denuncia, el problema ya es grande, ya es un hecho consumado en las etapas más importantes del proceso, y a los involucrados les será más difícil reconsiderar y corregir su conducta sin afectar su carrera académica, prestigio profesional y personal.

Por lo tanto, es de suma importancia prevenir y promover una cultura, y hasta una mística, de científicos cuyo principio de trabajo esté guiado por la integridad académica, tanto en la experimentación como en el trabajo de campo con seres humanos, animales, el medio ambiente y los ecosistemas; es importante también promover el respeto al otro, al colega, al compañero, al estudiante (Koepsell y Ruíz de Chávez, 2015). Este respeto al otro permitirá escuchar y conocer todo lo relacionado con nuestro tema de estudio y evitar riesgos. En el proceso, tiene que obtenerse el consentimiento voluntario e informado de los participantes (incluyendo los sujetos de estudio) Las entrevistas, los cuestionarios y la observación sólo se deben hacer cuando no existe fuente para obtener la información, pero siempre evitando riesgos o lesiones por la falta de integridad académica; en caso esto, es válido detener el proyecto, pues, de no hacerlo, se provocarían faltas por manipular, tergiversar y engañar con los datos y, posteriormente, con la publicación y la difusión que es la fase más abierta y pública. Esta última fase sería catastrófica y de duras consecuencias para los actores: divulgar datos alterados que no permitan comprobar y replicar los resultados afectaría a los propios autores y engañaría a la comunidad académica (Koepsell y Ruíz de Chávez, 2015). 
En esta práctica, las bibliotecas pueden jugar un papel protagónico en el seguimiento del proceso y de los datos, así como en la socialización de las conductas éticas de la investigación y de la publicación de resultados; un trabajo conjunto entre la academia y la biblioteca podría concretarse en talleres o ciclos de conferencias a alumnos, tesistas, becarios y académicos-investigadores que les permitan reflexionar en torno al trabajo científico sobre la base de la integridad, la honestidad y la conducta ética del sujeto y el seguimiento de todo el proceso de investigación.

\section{CoMités Y Códigos DE ÉTICA EN LA INVESTIGACIÓN}

Las posibilidades tecnológicas actuales y la ausencia de valores o cambios de prioridades éticas en los conjuntos sociales han potenciado los casos y las denuncias de hechos deshonestos y plagios en las investigaciones o productos creativos que se hacen públicos y afectan la confianza, no sólo en el individuo, sino también en las instituciones; más aún, afectan la credibilidad de la misma ciencia. La situación cada vez es más grave y, en algunos círculos, se vuelve un secreto a voces gracias a las TIC, que facilitan la detección del plagio y su difusión. Por lo que la ética de la investigación ha dejado de ser algo casual para obligadamente ser parte del proceso de la formación profesional de los investigadores (Litewka y Heitman, 2014; Shrader-Frechette, 1994).

El costo social, profesional y económico de un fraude, alteración de resultados o plagio, es muy alto e incluye a muchas personas y a instituciones, por lo que se tiene que actuar ante cualquier riesgo ya detectado: hay que prevenir y no lamentarse.

En la actualidad, los colegios académicos por disciplina, los grupos de investigación y las instituciones han desarrollado sus códigos de ética o lineamientos para desarrollar con integridad y honestidad todo proceso creativo o de investigación. El problema lo han enfrentado todas las áreas de la ciencia (las físicas, las biológicas, las sociales y las humanidades) y esta situación podríamos ejemplificarla con el Código de ética del Colegio de 
Etnólogos y Antropólogos Sociales (CEAS, 2014) y el Código de Ética de la Academia de Ciencias de Hungría (MTA, 2010).

El Código de los Antropólogos Sociales hace énfasis en el respeto hacia el otro, al derecho de los pueblos y a la dignidad humana, principios fundamentales para los estudios de estas disciplinas, además de otros apartados en los que se encuentra especial énfasis en: los sujetos con los que se investiga, los resultados, la veracidad, la responsabilidades y los derechos del equipo de investigación, las relaciones con los estudiantes y las buenas prácticas éticas en la docencia y la práctica profesional.

El código de la Academia de Ciencias de Hungría, por su parte, enfatiza en normas morales para una autorregulación de la comunidad científica, destacando la honestidad, la fiabilidad de los datos, la objetividad, la imparcialidad, la apertura a discusiones, además de cuidar la versión pública de los resultados; hace todos los reconocimientos de ley y las citaciones y referencias obligadas, más un apartado sobre las infracciones a las leyes vigentes: en cuanto al derecho de autor, las derivadas de un plagio, el mal uso y alteración de información, así como cualquier otro acto ilegal (MTA, 2010).

Como se puede ver en los dos ejemplos, que representan disciplinas muy distintas en diferentes países, la preocupación es la misma y, en ambos casos, se busca fortalecer a la ciencia y lograr aportaciones reales, verídicas y con procesos transparentes.

Se darán dos ejemplos más de instituciones de tipo nacional donde se realiza investigación y creación de conocimiento; éstos son: el Consejo Superior de Investigaciones Científicas (CSIC), de España, y la Universidad Nacional Autónoma de México (UNAM).

El CSIC hace énfasis en las buenas prácticas de la investigación y la responsabilidad individual que debe estar explícita en el compromiso contractual que el investigador adquiere con la institución; asimismo, destaca como principio que los intereses de la ciencia no deben primar sobre el ser humano. Este código deja muy claro que no debe haber desviaciones en el ejercicio de la investigación que busquen fama o méritos inmerecidos, de renombre o económicos, lo cual podría propiciar el fraude. 
Es necesaria la protección de resultados a través de la propiedad intelectual, la propiedad industrial y el derecho de autor, por lo que se debe tener especial atención en la definición de cada autoría en las publicaciones, así como el reconocimiento a los autores previos, por lo que se someterán a una revisión muy fina y profunda de la publicación científica que se pretenda emitir (MICINN, 2011).

La UNAM, en su código de ética, recoge los valores que orientan a una universidad pública en México; entre ellos, se puede rescatar: libertades de pensamiento y expresión, laicidad y tolerancia; y los más propios de nuestro tema, como:

Integridad y honestidad académica.- implica citar las fuentes de ideas, textos, imágenes, gráficos u obras artísticas, que se empleen y no sustraer o tomar información generada por otros [...]; no falsificar, alterar, manipular, fabricar, o fingir autenticidad de datos [...] en todo trabajo académico y de investigación [...]

Reconocimiento y protección de la autoría intelectual.- [...] La UNAM debe salvaguardar la autoría intelectual de todo tipo [...] promover su registro y actuar contra toda persona o institución que haga uso indebido de las mismas.

Transparencia en el uso de la información.- en cuanto a la información pública se debe actuar con suma transparencia y resguardar la privacidad y protección de la información personal (UNAM 2015).

Tanto los códigos de ética disciplinarios, como los institucionales, tienen muy claro el respeto al derecho de autor, a la creación de otro y a la responsabilidad de desarrollar una actividad científica con integridad y honestidad.

\section{Códigos de ÉTICA BIBLIOTECARIOS}

Se podría decir que, en términos generales, todos los colegios de profesionales o asociaciones tienen un código de ética; existen muchas similitudes entre los aspectos que abordan, y se tienen que 
destacar los de organismos que han sobresalido por su liderazgo en la profesión, la antigüedad de su activismo y la amplia cobertura geográfica de su membresía.

De las asociaciones u organismos líderes puede mencionarse a la Organización de las Naciones Unidas para la Educación, la Ciencia y la Cultura (UNESCO), American Library Association (ALA) y la Federación Internacional de Asociaciones de Bibliotecarios e Instituciones (IFLA). Todas ellas defienden el libre acceso a la información como un principio general de servicio bibliotecario, pero a la vez incluyen normas que regulan su uso en relación con el derecho de autor. Por ejemplo, la IFLA se compromete a apoyar las demandas de los usuarios sobre obras protegidas por el derecho de autor, pero buscando un balance para que los titulares del derecho de autor obtengan una remuneración económica justa por su propiedad intelectual (IFLA, 2012).

Vale la pena mencionar que la Organización Mundial de la Propiedad Intelectual (OMPI) tiene un Comité Permanente de Derechos de Autor y Derechos conexos que ha generado un Estudio sobre las limitaciones y excepciones al derecho de autor en beneficio de bibliotecas y archivos (2015), donde han estado presentes las observaciones de los organismos bibliotecarios mencionados.

En una revisión de códigos de ética de las asociaciones líderes de países latinoamericanos, el tema del plagio y la integridad científica, y sus diferentes variantes de robo de ideas están ausentes; el tema aterriza cuando la publicación del libro o artículo ya está disponible para el préstamo y el uso por el usuario y se enfatiza la dignificación de la profesión como personal de servicio y su compromiso con la sociedad y los usuarios de información.

De una revisión de los Códigos de Costa Rica, Cuba, Chile, México y Puerto Rico, se pueden encontrar constancias temáticas.

Tabla 1. Comparación entre codigos de ética bibliotecaria.

\begin{tabular}{|l|c|c|c|c|c|}
\hline \multicolumn{1}{|c|}{ Temas } & $\begin{array}{c}\text { Costa } \\
\text { Rica }\end{array}$ & Cuba & Chile & México & $\begin{array}{c}\text { Puerto } \\
\text { Rico }\end{array}$ \\
\hline Compromiso social & $\mathrm{X}$ & $\mathrm{X}$ & $\mathrm{X}$ & $\mathrm{X}$ & \\
\hline Igualdad/Equidad & $\mathrm{X}$ & $\mathrm{X}$ & & & $\mathrm{X}$ \\
\hline
\end{tabular}


Uso ético de la información...

Tabla 1. Comparación entre codigos de ética bibliotecaria [cont.]

\begin{tabular}{|l|c|c|c|c|c|}
\hline \multicolumn{1}{|c|}{ Temas } & $\begin{array}{c}\text { Costa } \\
\text { Rica }\end{array}$ & Cuba & Chile & México & $\begin{array}{c}\text { Puerto } \\
\text { Rico }\end{array}$ \\
\hline Libertad intelectual & $X$ & $X$ & & & $X$ \\
\hline Libertad de información & $X$ & $X$ & & & \\
\hline Disponibilidad & $X$ & & & $X$ & \\
\hline Acceso Abierto & $X$ & & & $X$ & \\
\hline Imparcialidad/Objetividad & & $X$ & & $X$ & $X$ \\
\hline Propiedad Intelectual & $X$ & $X$ & & & $X$ \\
\hline Derecho de autor & $X$ & $X$ & $X$ & & \\
\hline Legislación internacional & $X$ & & $X$ & & \\
\hline Censura & $X$ & & & $X$ & $X$ \\
\hline Mal uso/Abuso de la información & $X$ & & & & \\
\hline Ética profesional & $X$ & $X$ & $X$ & & \\
\hline Comunicación científica & & $X$ & & & \\
\hline Confidencialidad & $X$ & $X$ & $X$ & $X$ & $X$ \\
\hline
\end{tabular}

Fuente: Elaboración propia

De acuerdo con los códigos, la biblioteca y los bibliotecarios toman el tema del plagio, o el mal uso de la información, el respeto al derecho de autor y la propiedad intelectual, hasta que el resultado de una investigación, o una creación se ha hecho pública y forma parte de los servicios de la biblioteca. En todas las otras etapas del proceso de investigación no queda explícito el amplio trabajo que pueden hacer juntos el investigador y el bibliotecario, con el fin de prever cualquier abuso o alteración en la información que se utilice o se produzca; lo cual, si bien muchas veces es de manera premeditada, en otras es por prisas, por falta de una técnica de verificación de información, y por ignorancia de las normas éticas, de integridad científica del trabajo académico y de investigación, lo que no disminuye la gravedad del hecho.

También debe quedar claro que si el bibliotecólogo hace tareas de investigación, su actividad debe estar regida por los códigos de ética, integridad y honestidad científica y buenas prácticas de la investigación de cada institución, disciplina o área temática. 
LOS SISTEMAS DE EVALUACIÓN Y ESTÍMULOS ACADÉMICO-ECONÓMICOS

El sistema de evaluación del trabajo académico y de investigación se ha vuelto, en la mayoría de los países, un círculo perverso, ya que estos sistemas presionan por una producción objetiva y probada para avalar la producción de cada uno de los investigadores y, de esa manera, considerarlo objeto de un estímulo académico y económico extra a su salario nominal. Este sistema de evaluación está basado en productos terminados que se colocan en un circuito internacional de revistas que ya tienen un aval previo dentro de la comunidad científica; además de la conexión que tienen las editoriales con otras empresas del sistema de conteo y medición de la visibilidad del artículo, o del investigador, y el número de citas que reporta de acuerdo a los indicadores establecidos por dichas empresas, que son muchas veces los mismos para la humanidades que para las llamadas ciencias duras. Así, cada sector responde a metodologías, valores y cobertura diferente por los propios objetos de estudio y sus relaciones con el individuo en los planos tiempo-espacio y cultura-identidad (Koepsell y Ruíz de Chávez, 2015).

Si bien la presión de la evaluación es fuerte y con un peso específico en la cuantificación, sin atender otros aspectos como el beneficio social y la interacción con la comunidad de estudiantes jóvenes y muchos otros sectores de la sociedad, esto no justifica de ninguna manera la mala práctica de la investigación, la falta de honestidad y transparencia, el respeto al otro; hasta llegar al robo de ideas, a la alteración de resultados, al plagio, al fraude y, al final, ser infractores de normas éticas y normas legales de validez local e internacional, como la propiedad intelectual y el derecho de autor.

Si se quieren evitar las malas prácticas científicas, se tienen que analizar todas las causas y buscar soluciones acordes a la realidad actual y buscar otros sistemas de reconocimiento al investigador que no se vuelva un chantaje vía salario, ya que el estímulo económico es parte de la supervivencia del investigador, o la tarjeta de presentación para negociar otros recursos extra salariales y extra institucionales. El bibliotecario de la institución donde se realiza la investigación, entre sus actividades, debe tener el registro de lo 
que se investiga, así como verificar que no se está duplicando con publicaciones anteriores sobre el tema.

\section{LAS DENUNCIAS DE PLAGIO Y SUS CONSECUENCIAS}

En repetidas ocasiones se ha mencionado que cada vez se conocen más prácticas inadecuadas y faltas de ética en el trabajo de investigación y en el creativo. Gracias a la evolución de las TIC, cada vez es más fácil robar o alterar textos, datos, ilustraciones, fotografías; pero, al mismo tiempo es igual de fácil conseguir la ayuda tecnológica para detectar estas acciones negativas y alteraciones engañosas para presentar trabajos no propios del autor fraudulento o plagiario.

Cabe aclarar que en la legislación sobre derecho de autor no se usa la palabra plagio, por lo que cualquier demanda formal y legal deberá ser supervisada cuidadosamente en los aspectos jurídicos.

En cada país se podrá encontrar un catálogo que concentre la cantidad de plagios de personajes muy conocidos, distinguidos con premios y reconocimientos, aunque también aparecen otras personas que se llegan a conocer con la denuncia y así lograr una notoriedad negativa.

Se darán algunos ejemplos locales y de difusión internacional. En nuestra Universidad se puede dar cuenta de muchos alumnos, profesores e investigadores a los que se les ha comprobado plagios parciales o totales de tesis, artículos y libros:

a. En la Facultad de Filosofía y Letras se descubrió la historia de plagios reiterados de un profesor que sus denunciantes han dejado registrados en un blog, que lleva años funcionando con actualizaciones periódicas Yo (también) quiero un trabajo como el de Boris Berenzon (2013) ${ }^{1}$, con hechos documentados sobre

1 A través del blog, se denunció la situación docente, los plagios y el fraude académico en general de Boris Berenzon Gorn, ex 'profesor' en la Facultad de Filosofía y Letras de la UNAM, destituido en 2013. 
su vida académica (licenciatura, maestría y doctorado), que el plagiario se niega aceptar.

b. En dos universidades de México, se hicieron denuncias de dos académicos premiados y reconocidos, entre otros, por el Sistema Nacional de Investigadores (SNI). En este caso, también hubo reacciones públicas, tanto de las entidades que otorgaron el grado de doctor como de las universidades donde estaban contratados. Ambos investigadores pertenecían al SNI del Consejo Nacional de Ciencia y Tecnología (CONACyT); este organismo nacional y sus cuerpos colegiados, por lo tanto, analizaron el caso, ya que abiertamente se ponía en duda la integridad del propio SNI. El CONACyT hizo un comunicado público que difundió ampliamente la prensa, indicando que el Consejo aplicaría las medidas del reglamente del propio SNI. En consecuencia, los dos investigadores fueron expulsados por 20 años por mala conducta por plagiarios (2015).

c. Y uno más, de un personaje internacional: el escritor peruano Alfredo Bryce Echenique, con varias denuncias de plagio probadas en su país, a quien el jurado del Premio FIL 2012, otorgado por la Feria Internacional del Libro de Guadalajara, le confirió la distinción. El jurado y los funcionarios de la FIL recibieron la denuncia de las irregularidades probadas del escritor, las cuales tuvieron mucha resonancia en la prensa y en las redes sociales. No obstante, la FIL sostuvo el Premio, decisión desafortunada, ya que la comunidad cultural y académica se sumó a las protestas y eso dio una imagen negativa al premio.

Como se puede apreciar en los ejemplos presentados, las denuncias son cada vez más comunes, o al menos, se han difundido con más facilidad gracias a los medios de comunicación y a las redes sociales; también se puede ver que las reacciones han sido diferentes de acuerdo con la normatividad local y la aplicación de la Ley de Derechos de Autor, con la aclaración que esta ley no usa el término plagio (Roth, 2005; Arce, 2014).

Cuando se llega a situaciones extremas de denuncia sobre hechos que ya son del dominio público, donde la copia o alteración 
de un texto sin los permisos correspondientes se difunde de manera masiva, ya se hizo daño el propio autor y contagió a varias instituciones y personas que tuvieron que ver con el ilícito. Muchas veces, el bibliotecario también se entera al final del proceso, por lo que si quisiera ayudar a su institución tendría que verificar la validez de la denuncia y colaborar en cuantificar la magnitud del daño y aportar información para que las instancias oficiales y legales correspondientes tomen posibles medidas para que la institución no pierda su prestigio académico.

El apoyo CONSTANTE DEL BIBLIOTECólogo AL PROCESO DE INVESTIGACIÓN

Ya se mencionó en cada uno de los apartados algunas de las posibilidades que tiene el bibliotecario de participar y colaborar en el proceso de investigación-publicación, con el fin de ser parte del equipo de apoyo que proporcione información para desarrollar algunas actividades preventivas de malas conductas de investigación y difundir actividades que vayan formando actitudes de honestidad, integridad, transparencia y el respeto al otro y a su creación y producción, en todo trabajo académico, proceso de investigación y de creación, y por qué no, en su vida personal y profesional.

El bibliotecario y la biblioteca tiene que fortalecer su presencia, no sólo como una instancia que provee información, sino como un activo de apoyo académico en los grupos de investigación, lo que le permitiría participar desde que se gesta un proyecto de investigación, no como un coautor, sino como un apoyo técnico académico que desde su especialidad, que es el universo de la información registrada, aporte la información requerida en cada etapa del proceso, pero que no sólo la aporte sino que también la valide y la contraste con el área temática de que se trate.

Cuando se concluye el proyecto y ya hay resultados que requieren hacerse públicos, mediante reportes, artículos, libros o de cualquier otro tipo, la ayuda del bibliotecario es fundamental, 
ya que es el profesional que puede auxiliar para elegir las normas de redacción, el estilo de citación y referencia que predomine en la disciplina o que exija la editorial a la que se pretenda enviar la información, la verificación de datos bibliográficos y estadísticos, la verificación de citas textuales, y los correspondientes créditos a autorías presentes y precedentes.

En paralelo a estas actividades que puede y debe desarrollar el bibliotecario, su campo de trabajo se puede enriquecer en tareas ya establecidas, como la difusión de algunos temas bibliotecarios que deben conocer los usuarios. Una de ellas puede ser la socialización de aspectos de la formación de actitudes en los jóvenes investigadores, de los becarios y estudiantes que se integran a equipos de investigación o que están en proceso de elaboración de sus tesis, que pueden transmitirse a través de un taller o un curso; podría también promover buenas prácticas de investigación, así como la honradez, la transparencia, las obligaciones del derecho de autor y en toda actividad académica. También una conducta ética como ser humano que esté basada en el respeto al otro, en la integridad, en la libertad de pensamiento y en la inclusión de afinidades y diferencias.

Otra actividad que puede generarse en una biblioteca con cobertura amplia de un centro de investigación, o universidad, sería diseñar amplias campañas de difusión de estos aspectos y que incluyan a los medios masivos, a las redes y que utilicen medios visuales como pósters, folletos, videos, etc.

\section{REFLEXIÓN FINAL}

Como se puede constatar, el campo de acción del bibliotecario de acuerdo con las transformaciones sociales, económicas y tecnológicas se transforma, amplía e incursiona en áreas que se vuelven nichos de oportunidad para apoyar actividades centrales de los grupos a los que sirve la biblioteca.

En el caso de estimular conductas éticas en los académicos, investigadores y creadores, y evitar plagios o robos de ideas, 
se tiene un gran espacio de trabajo en las bibliotecas académicas y de investigación y, por consiguiente, en las universidades y otros centros de educación superior y de investigación. Pero para estimular las actitudes de una conducta ética de respeto al otro y de formas de convivencia respetuosas e incluyentes, todas las bibliotecas tienen tareas por hacer.

\section{Bibliografía}

Arce, J. R. (2014) "Interrogantes básicas sobre los derechos de autor”. Revista Bibliotecas, vol. 32, núm. 1, 25-33.

Asociación Cubana de Bibliotecarios, Código de Ética de la Asociación Cubana de Bibliotecarios [en línea]. Disponible en: <http://www.cpicmha.sld.cu/ metodologias/codigo-de-etica.pdf $>$.

Brown, A. y C. Waelde (2015) "IP, Disability, Culture and Exceptionalism: Does Copyright Law Deal with Difference?". en Graeme B. Dinwoodie (ed.), Intellectual Property and General Legal Principles. Is IP a Lex Specialis?, Cheltenham: Edward Elgar Publishing Limited.

"Bryce Echenique: de plagios y premios". [Responsable del texto: Roberto Breña. Junto a él lo firman Soledad Loaeza, Antonio Azuela, Ariadna Acevedo, Fernando Escalante, Mauricio Tenorio, Benjamín Arditi, Alfredo Ávila, Blanca Heredia, Ignacio Almada, Gerardo Esquivel y José Antonio Aguilar], El País, 14 de noviembre del 2012. Disponible en: <http://cultura.elpais.com/ cultura/2012/11/13/actualidad/1352833928_446496. html>.

CEAS, Código de Ética del Colegio de Etnólogos y Antropólogos Sociales AC. Disponible en: <http://www. ceas.org. $\mathrm{mx} /$ index.php? view $=$ article $\&$ catid $=58$ :etica $\&$ $\mathrm{id}=471: 2016-02-24-21-39-02 \&$ format $=$ pdf $>$. 
Colegio de Bibliotecarios de Chile A.G., Código de Ética Profesional. Disponible en: <http://www.ifla.org/files/ assets/faife/codesofethics/chile.pdf $>$.

Colegio Nacional de Bibliotecarios [México], Código de ética profesional. Disponible en: <http://biblio.colmex. $\mathrm{mx} / \mathrm{cnb} / \mathrm{cnb}$-codigo.htm $>$.

Colegio de Profesionales en Bibliotecología de Costa Rica, Código de Ética. Disponible en: <www.coprobi.co.cr/ contenido/wp-content/uploads/2014/07/C\%C3\%B3digode-\%C3\%89tica-COPROBI.pdf $>$.

CONACYT, "CONACYT no tolera faltas éticas que ponen en duda la integridad del Sistema Nacional de Investigadores", 3 de agosto de 2015 [comunicado en línea]. Disponible en: <www. conacyt.mx/index.php/comunicacion/comunicadosprensa/492-conacyt-no-tolera-faltas-eticas-que-ponen-en-duda-la-integridad-del-sistema-nacional-deinvestigadores $>$.

COPE, The Committee on Publication Ethics. Disponible en: <http://publicationethics.org/>.

D'Agostino, G. (2015). "Contract lex rex: Towards Copyright Contract's Lex Specialis", en Graeme B. Dinwoodie (ed.), Intellectual Property and General Legal Principles. Is IP a Lex Specialis?, Cheltenham, Edward Elgar Publishing Limited.

Forge, J. (2008) The Responsible Scientist. A Philosophical Inquiry, Pittsburgh: University of Pittsburgh Press. 
Gobierno de España-Ministerio de Ciencia e Innovación MICINN, (2011). Código de buenas prácticas científicas del CSIC. Disponible en: <http://www.bioetica.unican. es/cbe_docs/cbp_CSIC.pdf $>$.

Hamilton, N. W. (2002). Academic Ethics. Problems and Materials on Professional Conduct and Shared Governance, USA: American Council on Education-Praeger Publishers.

IFLA. Postura de la IFLA sobre los derechos de autor en un ambiente digital. Disponible en: <http://www.ifla.org/ node/7300>.

Hungarian Academy of Sciences Budapest. (2010) Science Ethics Code of the Hungarian Academy of Sciences. Disponible en: <http://asm.md/galerie/file/SEC_\%20HAS .pdf>

Koepsell D. R. y M. H. Ruiz de Chávez. (2015). Ética de la investigación. Integridad científica. México: Comisión Nacional de Bioética (COBIOETICA) - CONACyT.

Litewka, S. y E. Heitman. (2014). "Discuten sobre la ética en la investigación científica en el IIB". Gaceta Biomédicas, vol. 19, núm. 2, 5-7. Disponible en línea: <http:// www.biomedicas.unam.mx/wp-content/gacetas/2014/ febrero.pdf?x21431>

Mah, E. C. (2015) "How Journals and Institutions Can Work Together to Promote Responsible Conduct", en Samantha L. Elliot, Beth, A. Fischer et al. (eds.), Perspectives on Research Integrity, Washington, DC: ASM Press. 
OMPI, Resumen del estudio sobre limitaciones y excepciones en materia de derecho de autor en favor de bibliotecas y archivos: versión actualizada y revisada (sccr/30/3). Disponible en: <http://www.wipo.int/edocs/ mdocs/copyright/es/sccr_30/sccr_30_3.pdf >.

Preer, J. L. (2008). Library Ethics. Libraries Unlimited.

Roig, M. "Critical Issues in the Teaching of Responsible Writing”, en Samantha L. Elliot, Beth, A. Fischer et al. (eds.), Perspectives on Research Integrity, Washington, DC: ASM Press.

Roth Seneff, A. (2005). "Propiedad intelectual versus conocimiento. El debate sobre 'acceso abierto'”. Relaciones Estudios de historia y sociedad, vol. 26, núm. 104, 191-216.

Shrader-Frechette, K. (1994). Ethics of Scientific Research, Maryland: Rowman \& Littlefield Publishers, Inc.

Sociedad de Bibliotecarios de Puerto Rico. (2002). Código de ética. Disponible en: <www.sociedadbibliotecarios. org/index.php/sbpr-ethics-code-menu-item $>$.

unAm. Código de ética de la Universidad Nacional Autónoma de México. Disponible en: <http://www.ifc. unam.mx/pdf/codigo-etica-unam.pdf $>$.

Villoro, L. (1999). Estado plural, pluralidad de culturas. México: UNAM,FFyL: Paidós. 
Wager, E. (2015) "How Should Journal Editors Respond to Cases of Suspected Misconduct?", en Samantha L. Elliot, Beth, A. Fischer et al. (eds.), Perspectives on Research Integrity. Washington, DC: ASM Press.

Yo (también) quiero un trabajo como el de Boris Berenzon [Blog en que se denunció la situación docente, los plagios y el fraude académico en general de Boris Berenzon Gorn, ex 'profesor' en la Facultad de Filosofía y Letras de la UNAM, destituido en 2013]. Disponible en: <http://yoquierountrabajocomoeldeboris.blogspot. $\mathrm{mx} />$.

Zea L. (2014). Filosofía y cultura latinoamericanas, Caracas: Fundación Centro de Estudios Latinoamericanos Rómulo Gallegos. 


\title{
Desafíos éticos en la aplicación de los lenguajes controlados
}

\author{
Catalina Naumis PeÑa \\ Instituto de Investigaciones Bibliotecológicas y de la Información, \\ Universidad Nacional Autónoma de México, México
}

\section{INTRODUCCIÓN}

in duda el título de este trabajo marca un cierto riesgo por- que implica una relación con la filosofía entrando por la puerta de la ética. En principio se trata de llevar un tema filosófico, con la cautela que corresponde, pero con la idea de buscar respuestas, junto con la comunidad científica de la bibliotecología, a la existencia o no de desafíos éticos en la utilización de los lenguajes documentales.

La incursión en un tema filosófico parte de la suposición que las ciencias sociales y humanas tratan una realidad única, más allá de las visiones concretas o puntuales de cada una de las comunidades científicas que la integran.

El pensamiento subyacente es que una mirada a los lenguajes controlados usados para organizar la información y el conocimiento es, desde la ética, una oportunidad para nuevas reflexiones.

En la Bibliotecología se pretende organizar la información y el conocimiento a través de estructuras que representen un todo documental. Y Abric menciona lo siguiente:

La representación no es así un simple reflejo de la realidad, sino una organización significante. Esta significación depende a la vez 
de factores contingentes (de circunstancias dice Flauvert) - naturaleza y obligaciones de la situación, contexto inmediato, finalidad de la situación-y factores más generales que rebasan la situación misma: contexto social e ideológico, lugar del individuo en la organización social, historia del individuo y del grupo, desafíos sociales. (Abric, 2001: 13)

En esta cita existen elementos para discutir los lenguajes documentales desde una perspectiva diacrónica bastante más amplia que su simple uso y aplicación en el presente. La organización del conocimiento por medio de lenguajes documentales, ha respondido a diferentes etapas y necesidades del proceso de contenidos. Las primeras herramientas diseñadas para representar información en catálogos como concepto social comienzan a desarrollarse a fines del siglo XIX. Atrás de ellos están los pensamientos que van permeando a la sociedad desde otras trincheras, y que influyen en la asunción de posiciones con respecto al problema, sin duda relacionado con la lengua.

Viene a la medida recordar la frase de Yule en su libro sobre el lenguaje "[...] en el estudio del lenguaje, algunas de las cuestiones interesantes surgen a partir no tanto de preguntarse cuáles son sus componentes sino a propósito de la forma en que se usa" (Yule, 1998: 159). Los lenguajes documentales usan los elementos de la lengua que representan contenidos, y presentan al usuario un resumen en palabras, de los mismos.

Por otra parte, a lo largo de la historia de la filosofía se han discutido las conexiones teóricas entre el lenguaje y la dimensión ética del hombre. Es precisamente en este cruce donde, se supone, existe un respaldo de los modos de asumir la representación de contenidos en la información y el conocimiento generado.

Es necesario reconocer las muchas perspectivas y modos de abordar la ética, que sólo en el siglo XX se vertebra en torno a tres grandes ejes o tendencias: la filosofía analítica, la corriente fenomenológico-existencialista y los marxismos. Las tres se han visto afectadas por lo que Richard Rorty ha denominado el giro lingüístico, por cuanto esa atención preferente al lenguaje no ha 
sido patrimonio de la filosofía analítica, aun cuando ésta hiciera de ello su particular enseña a comienzos del siglo XX, sino que ha acabado por imponerse en las otras grandes corrientes filosóficas del mismo siglo (Gómez Sánchez, 2002: 10).

Se proponen las siguientes preguntas como base de la reflexión acerca de la relación ética con los lenguajes documentales, como una guía para abordar el problema y compartir las preocupaciones que despiertan la aplicación de los lenguajes controlados:

- ¿Traducir términos significativos de una cultura a otra donde no lo son, es o no un desafío ético?

- ¿El mantenimiento histórico en los catálogos de biblioteca plagados de términos ofensivos en la cultura actual, es o no un desafío ético?

- ¿Es posible para un indizador desprenderse de sus prejuicios y negociar con los intereses de los usuarios?

- ¿Es posible construir lenguajes documentales interactivos entre información y usuarios asegurando que son éticamente correctos?

- ¿Las redes sociales son una opción en materia de control terminológico?

- ¿Cómo han influido las corrientes de pensamiento en la representación terminológica de contenidos informativos y de conocimiento?

No todas estas preguntas podrían tener una respuesta en los siguientes apartados, pero reflejan las preocupaciones que se generan al revisar la literatura bibliotecológica relacionada con el tema y seguramente son una base para discutirlo.

\section{LENGUAJES DOCUMENTALES Y HABLA}

Los lenguajes documentales contienen términos autorizados que se usan para representar, en un ejercicio de clasificación, los contenidos plasmados en documentos. La representación como un 
proceso de tipo social está sometido a la aceptación o no de las representaciones, en la medida que responden a las expectativas de quienes las utilizan. La distancia del indizador con la ética es corta y directa; porque el acto de clasificar es asignarle un lugar a algo, y quitarlo o restarlo, de otro.

La evaluación de los sistemas técnicos debe hacerse desde dos niveles: uno interno a cada sistema y otro externo: 1) La evaluación interna se realiza considerando su eficiencia. La eficiencia técnica se refiere a la adecuación de los medios a los fines propuestos. También importa la eficacia, que se refiere a que se logren realmente los fines que se trata de alcanzar. 2) La evaluación externa se realiza desde el punto de vista del contexto social, cultural y ambiental donde se aplicarán los sistemas técnicos y al cual afectarán las consecuencias de su aplicación (Siurana, 2009: 211). El presente trabajo se enfoca únicamente a la evaluación externa de los lenguajes documentales influenciados por el contexto social, cultural e histórico desde el cual se construyen.

La construcción, mantenimiento y uso de diccionarios no es ajena a la problemática planteada en los lenguajes documentales. En un análisis sobre el Diccionario de la Real Academia Española (DRAE) y las palabras relativas a los gitanos y judíos, se comentan aspectos que se relacionan con los conflictos reflejados en los catálogos de grandes sistemas bibliotecarios en los temas escogidos para calificar contenidos.

Existen palabras que se definen a través de los años de la misma manera y estas son objetos inanimados o incluso las voces definitorias de seres vivos cuando éstos han permanecido inalterados en su ser y en la percepción social de su esencia, con toda la tradición cultural que arrastran consigo, rara vez alterada en el seno social. Sin embargo, no puede ocurrir lo mismo cuando la realidad que se trata de definir pertenece a la esfera de la vida social, la de los individuos, sus opiniones y creencias, sus actitudes frente a la vida y a los demás miembros de la sociedad, puesto que esto es, sin duda, lo que más ha variado a lo largo de los años. (Forgas Berdet, 2011: 372) 
Desde fines del siglo XIX comienzan a usarse lenguajes documentales como proceso social articulado, y es ahora en el siglo XXI que aparecieron nuevos modos de aplicar términos para representar contenidos, siglo en el cual aún conviven con las prácticas que comenzaron en el siglo XIX.

Desde el comienzo del uso de los lenguajes documentales para clasificar contenidos, se han desarrollado los conocidos encabezamientos de materia dirigidos hacia un usuario que no opinaba y todavía utilizados en los grandes sistemas de bibliotecas.

Los profesionales de la información a través de listados con términos que conforman un entramado de significados, facilitan al usuario de la información encontrar pensamientos, acciones, objetos o hechos en una gran masa documental.

Los corpus de términos en los lenguajes documentales son extraídos de la lengua general o de la lengua especializada en algún área del conocimiento u actividad. Es decir, los lenguajes documentales contienen una selección de expresiones lingüísticas de la lengua general o especializada para organizar información.

En la realidad, los lenguajes documentales sólo registran el conocimiento nuclear de cada palabra, o sea que existe un énfasis en un significado prescriptivo, descuidando el carácter comunicativo de las expresiones lingüísticas.

Uno de los primeros problemas que surgen en torno a ese conjunto de expresiones lingüísticas es si pueden portar significado como en un acto de habla. Al respecto Frápolli y Romero explican:

"Creer que esto es así supondría mantener que lo que las expresiones significan, lo que representan, coincide con el uso que de dichas expresiones hacen los hablantes". Quien no atribuye rasgos distintos a estos dos tipos de significado suele creer que la gente normalmente quiere decir lo que dice mediante el significado de las expresiones que usa y que lo que dice coincide con este último significado. Sin embargo, una creencia de este tipo impide pensar cómo usa el hablante los recursos lingüísticos y la negociación que existe con el que escucha. De este modo, es mejor pensar que 
los actos de habla y las expresiones son portadoras de distintos significados (Frápolli \& Romero, 1998: 30).

Esta relación entre hablante y oyente forma parte de la pragmática del significado propuesta por H.P. Grice y explicada también por Acero, Bustos y Quesada (2001: 167). Es decir existe una fuerte vinculación entre el reconocimiento de la intención del hablante según su conducta verbal y la captación o reconocimiento del significado por el oyente.

En el terreno de la lingüística cognitiva se plantea que hacer una distinción adecuada entre semántica y pragmática es difícil. Y explica que "[...] la semántica se debe ocupar del conocimiento nuclear de cada palabra, mientras que otro tipo de conocimiento adicional que pueda ser evocado por el uso concreto y contextual de una palabra pertenece al terreno de la pragmática" (IbarretzeAntuñano y Valenzuela, 2012: 49).

Sin anclarse en la semántica o la pragmática Lara, un lingüista dedicado a la lexicografía, explica la dinámica del uso de las palabras desde una óptica más pragmática que semántica:

"[...] Usamos las palabras para darnos a entender y sin reflexionar mucho en ellas. Brotan de nuestros labios en un flujo casi constante, correspondiente al intervalo infinitesimal que tardan nuestros pensamientos en articularse en lengua. No sólo eso: la articulación verbal de nuestra habla es seguramente un elemento central de la propia organización del pensamiento. Trabajamos con conceptos muchas veces bien definidos, que no requieren una formulación verbal, pero lo cierto es que para aprender esos conceptos tuvimos la necesidad de que alguien nos los comunicara hablando, además de luego pasar a practicarlos hasta tener un conocimiento pleno de ellos" (Lara, 2011: 101).

Al fin y al cabo, detrás de la expresión de Lara existe el respaldo de teóricos trascendentes que también han estudiado el fenómeno como por ejemplo Marx, quien expresa que el lenguaje es la realidad inmediata del pensar y, como ya se comentó párrafos 
arriba, la ética del siglo XX en general es una ética que pone su atención preferente en el lenguaje en su aspecto comunicativo.

La palabra es una manera de afirmarse uno mismo frente a los demás y de defender sus ideas. Puede tranquilizar y ayudar a resolver los problemas. Pero también los crea; te expone más a la mirada de los demás y no siempre es fácil entender que existen otras ideas, diferentes a las que han sido la propia manera de interpretar situaciones, objetos, hechos o acciones. Entonces para evitar los pleitos se puede optar por callar. ¿Tienes el derecho a herir a los demás con tus palabras o a revelar sus secretos? Más aún, porque una vez dichas las palabras no regresan. Las palabras tienen un peso y un valor.

Wittgenstein ejemplifica la relación con la realidad al explicar cómo un individuo desde el interior de su casa, ve a lo lejos, desde una ventana, a un hombre que camina con dificultad, moviendo los brazos como si remara; y la interpretación que se puede hacer de ella puede cambiar mucho al conocer lo que está sucediendo afuera: existe una tormenta y un viento fuerte que viene del mar.

Las expresiones lingüísticas en el caso particular que se analiza en este trabajo se integran por palabras simples, compuestas o frases relacionadas entre sí, ya sea por equivalencias, categorías jerárquicas, asociaciones entre términos o explicaciones acerca de los posibles usos en la indización de contenidos sobre una temática en particular. Con estas expresiones se califican los textos, escritos o hablados, extraídos de la lengua general o aún del lenguaje de una especialidad, donde la combinación de los signos permite transmitir un número infinito de mensajes para lograr la comunicación a través del contexto. (Ávila, 2007: 18)

El reto al aplicar los lenguajes documentales es calificar contenidos textuales agrupables bajo una expresión lingüística, que no sólo recoja el significado lexicográfico, sino el uso pragmático de la expresión.

Es decir, construir y asignar descriptores o encabezamientos es guardar la distancia entre el indizador y su modo de percibir el mundo y entender el pensamiento, hecho o acción que busca transmitir el autor del contenido a indizar. En definitiva, se trata 
de discernir entre prejuicios propios e imbuirse de la obra a resumir, a través de una construcción terminológica que explique al usuario de la información el contenido a encontrar en ella, sin calificaciones que puedan interpretarse de forma equívoca por los usuarios que consultan los catálogos construídos. Sin embargo, el significado debe ser dinámico y relacionado con la realidad social. ¿Se puede lograr?

\section{LAS RELACIONES SOCIALES Y LOS LENGUAJES DOCUMENTALES}

Las inquietudes por crear listas de encabezamientos de materia surgen desde 1879 y se concreta la integración del comité para elaborarlos en 1892 con la participación de Charles Cutter. En 1895 se concluyeron los trabajos relacionados a los encabezamientos de materia y se publica la primera lista de encabezamientos de materia de la que se tiene registro List of Subject Headings for use in dictionary catalog de la American Library Association (Pettee, 1946).

J. C. Hanson y Charles Martel fueron los responsables de la División de Catalogación de la Biblioteca del Congreso en EEUU (United States Library of Congress) entre 1897 y 1930 y recopilaron los encabezamientos asignados en la catalogación temática a partir de 1898 para sostener el control bibliográfico que ejerció y ejerce aún esa biblioteca, ahora continuada por nuevas generaciones.

En 1934 se publica una primera guía de encabezamientos en español. A partir de ahí se continúan publicando otras listas en éste y otros idiomas, pero las únicas que mantienen una actualización constante son las Library of Congress Subject Headings (LCSH) en el idioma inglés.

Las listas de encabezamientos están estructuradas en forma prescriptiva, con un significado que pretende ser el nuclear. Los temas asignados en los catálogos son generalmente los que están autorizados en ellas. El indizador o catalogador establece una negociación entre lo que entiende del contenido a sintetizar (a grandes rasgos porque son listas de tipo enciclopédico) y los encabezamientos que puede utilizar. 
Muchas de las bibliotecas que mantienen listados de encabezamientos de materia en otros idiomas, los traducen de los LCSH porque sus realizadores pregonan la actualización constante que realizan.

La solución de optar por una traducción de listas elaboradas en otros contextos obliga muchas veces al indizador, cuyo tiempo de calificación está restringido, a tomar la decisión de traducir el encabezamiento, en buena parte de las ocasiones, con un resultado erróneo para el contexto social. Lamentablemente, estas traducciones no se realizan en forma consensuada por un comité que las autorice y aún los temas descriptivos asignados quedarán como prescriptivos para las clasificaciones donde se utilicen a posteriori.

La consecuencia es observable si se revisan los temas asignados en los catálogos mexicanos, por ejemplo, con respecto a los pueblos originarios, porque no reflejan el enfoque que prevalece en el país desde hace varias décadas. Se impone un modelo universalista que no funciona cuando comienza a abundar la información y a manejarse en forma masiva. Quizás por inercia o porque en grandes sistemas de bibliotecas parecerían funcionar las listas de encabezamientos, o porque la biblioteca del Congreso de los Estados Unidos ha continuado con la actualización de sus encabezamientos; éstas listas han seguido siendo utilizadas en el siglo XXI.

Existe otra parte de la historia que comienza después de la primera mitad del siglo XX con pensamientos asentados en las ciencias sociales sobre un proceso de la comunicación que opera en la posibilidad de entender al otro. Pensamientos que descansan en la ética del siglo XX, como es el caso del discurso de Habermas sobre "[...] una ética procedimental que proporciona una estructura para la instauración de una normatividad común colegislada por todos los implicados a través de una discusión irrestricta que buscase la generalización de sus intereses" (citado por Gómez Sánchez, 2002: 51).

La posmodernidad es amplia y se aplica a un conjunto de corrientes diversas, pero parten de la base del fracaso del modernismo en su intento de lograr la emancipación de la humanidad. El posmodernismo se decanta por la cultura popular, valora y promueve la diversidad y trabaja por entender al otro, no considerado 
en el modernismo. Otro aspecto importante a evitar son los prejuicios eludiendo ser moldeado por las subjetividades impuestas y el aspecto que se destaca líneas arriba del giro lingüístico como creador de la realidad. Por último, un pensamiento subyacente que se impone en el postmodernismo es que la verdad es cuestión de perspectiva o contexto.

En el marco del posmodernismo en la bibliotecología y en los lenguajes documentales aparecen los tesauros especializados en una temática, la consideración de las necesidades del usuario y la construcción en la cultura e idioma de una comunidad.

A partir de los años 60 con la revalorización del usuario de la información, se puede establecer que existe una búsqueda de la objetividad para que la perspectiva del indizador no influya, porque lo principal es comprender las necesidades informativas del usuario. Esto se refleja, por ejemplo, en cuanto a la univocidad que se proclamó durante años, y se cambió por un entramado real de significados para guiar al usuario, y por una una relación comunicativa enriquecida, de acuerdo con sus necesidades.

Esta distancia que se refleja entre las listas de encabezamientos y los tesauros es consecuencia de las corrientes de pensamiento que prevalecen en la sociedad y permean a la bibliotecología. A continuación, se presenta un cuadro comparativo, en el marco de la representación de la información, entre las dos corrientes con respecto a los lenguajes documentales que muestra cómo se reflejan en los lenguajes utilizados para indizar (Moreiro, 2007: 29).

Tabla 1. Corrientes en la representación de la información.

\begin{tabular}{|l|l|}
\hline \multicolumn{1}{|c|}{ Positivista } & \multicolumn{1}{c|}{ Postmoderno } \\
\hline - Formas apriorísticas de representación basadas en & - Categorías funcionales. \\
categorías universales. & - Preponderancia de las relaciones asociativas. \\
- Preponderancia de las relaciones jerárquicas & - Primicia de la función comunicativa del documento. \\
- Documento como soporte del conocimiento. & - Información vista desde la relación producción- \\
- Información vista desde la producción o desde la & recepción del mensaje. \\
recepción. & - El usuario como sujeto de la interpretación. \\
- Función pedagógica de la bibliotecología. & - Sistemas de información como instrumentos del \\
- Sistemas de información de carácter explicativo. & proceso de mediación. \\
\hline
\end{tabular}

Fuente: Moreiro $(2007,29)$. 
La bibliotecología de la actualidad presenta el movimiento de los datos enlazados, éste ha introducido una nueva dinámica y, sobre todo, el tratamiento en pequeños ámbitos especializados interaccionando entre sí y en la lengua del usuario. Sin embargo, sólo en las redes sociales se presentan fenómenos como la tecnología wiki que integra al usuario como protagonista.

La equivalencia de significados y la guía entre ellos es una característica de los datos enlazados en los catálogos y las ontologías que se desarrollan a partir de los tesauros.

Los datos enlazados conectan las entradas que se hacen por un tema en una base de datos a diferentes fuentes que generan información adicional y en el idioma de solicitud, aunque se pueden consultar en otras lenguas. Una sola base de datos para el universo, como deseaban Paul Otlet y La Fontaine. Las ontologías también trabajan con una URI para cada entrada, y la tecnología de la web semántica que permite desarrollar las ligas entre temas, con la finalidad de conectarlas con los contenidos.

En la actualidad, el entramado para recuperar contenidos por temáticas calificadoras refleja esa necesidad social de buscar una relación más dinámica entre la información y el usuario, como se observa en los modelos mencionados en el párrafo anterior, pero nada comparable a la dinámica de un sistema como el de la Wikipedia o las wikis semánticas que integran al usuario quien decide si una autoridad ha caído en desuso o cual es la expresión lingüística más simple, directa y sin elementos prescriptivos absolutos(Jiménez-Pelayo, 2008: 188).

La Wikipedia es un diccionario y no es el mismo caso que los lenguajes documentales, pero tiene un control de autoridades que se asemeja a los que se elaboran para complementar los catálogos, con una dinámica totalmente diferente.

En una wiki semántica dedicada a los vegetales, la página para pepinos además de la información sobre las propiedades medicinales, presenta las condiciones climáticas para el éxito de la planta, los productos derivados que se pueden obtener, el modo de presentarlos y cómo combinarlos. Es decir se contempla en un solo lugar un tema en diferentes contextos. Otras etiquetas semánticas 
en la página sobre los pepinos podrían indicar recetas de cocina, colores, tamaños, etc. Una de estas páginas es la Wikidata que fue lanzada el 30 de octubre de 2012 como nuevo proyecto de la Wikimedia.

El movimiento de los datos enlazados en la bibliotecología pretende interrelacionar los catálogos para obtener un resultado semejante, y en algunos casos el éxito ha sido llamativo, pero todavía queda mucho por hacer, sobre todo en la equivalencia terminológica en español.

\section{LA ÉTICA DEL LENGUAJE}

Los nuevos modelos que se gestan en la actualidad, con relación a la indización y la recuperación de contenidos recuerdan que el lenguaje humano soporta un modo de sociabilidad que se caracteriza por las valoraciones morales. El hombre posee lenguaje y posee, también, capacidad ética de discernimiento acerca de la posibilidad de entender al otro.

En ese uso pragmático del lenguaje "[...] Se intenta poner de manifiesto que en el uso intersubjetivo del lenguaje, ya sea en la comunicación, el diálogo, la invocación, la argumentación, o en algún otro juego lingüístico, ya está vigente, secreta, pero insoslayablemente, una dimensión ética originaria, la cual no puede ser ya ni refutada ni olvidada, porque recurre insistentemente cada vez que abrimos la boca para articular, en el seno de una comunidad lingüística, la más mínima palabra con sentido" (Rojas, 2000: 37).

Es decir, en el lenguaje mismo está la base de la moralidad y afirma Rojas: "Allí donde hay lenguaje, hay también inexorablemente ética [y agrega ...] como su argumentación no depende de la estructura semántica o gramatical de ninguna lengua, sino de la mera existencia del lenguaje, arte social y comunitario, las conclusiones de la ética del lenguaje no dependerán de ningún particularismo, sino que podrán y deberán ser consideradas como universales de pleno derecho" (Rojas, 2000: 41). 
En el citado artículo de Rojas se comparan dos propuestas de la acción comunicativa: la de Jürgen Habermas y la teoría ética de Emmanuel Levinas.

Las dos propuestas se basan en que "[...] hablar es decir algo a alguien: y esta direccionalidad, esta tensión interpersonal que traslada mis palabras hacia un destinatario, implica una "lógica" específica, una lógica que no puede entenderse a partir de las simples articulaciones de lo Dicho, ni está meramente al servicio suyo como momento necesario de la expresión:" (Rojas, 2000: 41)

Una vez analizado el trabajo de comparación que realiza, se observa que la propuesta de Emmanuel Levinas es la que parecería sustentar la interacción presente en el control de autoridades temáticas que se impone en la actualidad.

Del lema ilustrado clásico, libertad, igualdad y fraternidad, Habermas aprehende los dos primeros valores; pero en su teoría, no hay lugar sistemático alguno para el tercero. Levinas no sólo elabora con detalle ese tercer valor, sino que, más radicalmente, intenta mostrar que sólo a partir de la fraternidad, y de la solidaridad en ella implícita, pueden fundarse, pensarse y ejercerse sin excesos, tanto la libertad como la igualdad. Sin ella, estos dos valores son ciegos, despojados de dirección y medida (Rojas, 2000: 56).

Los sistemas de información tienden a incorporar la interacción del lenguaje documental e indizador con el usuario. Luego que se obtenga una solución para resolver esta dinámica acorde con un pensamiento ético que la sustente, aparecerán otros problemas que seguramente necesitarán de otros soportes éticos, lingüísticos y bibliotecológicos. Lo seguro es que existe una dinámica de cambio que a veces se olvida, está asentada en las ciencias sociales y humanísticas en general y el pensamiento subyacente que lo guía.

\section{CONSIDERACIONES FINALES}

Para concluir, se observa que la discusión sobre este problema no es fácil y está pendiente, pero es recomendable asumir que no 
existen políticas lingüísticas en México en los sistemas de información y las posibilidades institucionales no ayudan, sólo grandes sistemas con servicio universal pueden aspirar a trabajar mediante un estudio sistemático del lenguaje a utilizar para calificar contenidos.

Otro tema insoslayable es que tanto con el positivismo o con el posmodernismo se aceptan las políticas que marcan grandes empresas globalizadas y que las tendencias en las ciencias sociales y humanísticas sustentan diferentes modos de acceder a los controles de autoridades con los usuarios (entre ellos el uso del lenguaje natural), pero la historia muestra que en el fondo, las soluciones se imponen desde los países más desarrollados y es poco probable que no existan intenciones de cuidar sólo de sus intereses.

\section{Bibliografía}

Abric, J. C. (2001). Prácticas sociales y representaciones. México D.F.: Ambassade de France-CCC IFAL.

Acero, J. J., E. Bustos y D. Quesada. (2001). Introducción a la filosofía del lenguaje. Madrid: Ediciones Cátedra.

Ávila, R. (2007). La lengua y los hablantes. $4^{\mathrm{a}}$ ed. México: Trillas.

Ducrot, O. y T. Todorov (1974). Diccionario enciclopédico de las ciencias del lenguaje. México: Siglo XXI Editores.

Esquivel Estrada, N. H. (2008). Viabilidad de la ética en los inicios del siglo XXI: enfoque desde la bermenéuti$c a$. México: Centro de Estudios de la Universidad. Universidad Autónoma del Estado de México. Editorial Torres Asociados. 
Forgas Berdet, E. (2011). "Gitanos y judíos en la Real Academia." De la lengua por sólo la extrañeza: estudios de lexicología, norma lingüistica, historia y literatura en homenaje a Luis Fernando Lara. México: El Colegio de México. Vol 1, 371-395.

Frápolli, M. J. y E. Romero. (1998). Una aproximación a la filosofía del lenguaje. Madrid: Síntesis.

Gómez Alonso, P. (1958). La ética en el siglo XX. México: UNAM.

Gómez Sánchez, C. (2002). Doce textos fundamentales de la Ética del siglo XX. Madrid: Alianza Editorial.

Jiménez Pelayo, J. (2009) "Wikipedia como vocabulario controlado: ¿está superado el control de autoridades tradicional?" El Profesional de la Información, vol. 18, núm. 2, 188-201.

Lara, L. F. (2011). "La significación del tiempo en las lenguas”. Estudios de Lingüística Aplicada, vol. 29, núm. 53, 99-111.

Lingüística cognitiva (2012) / Iraide Ibarretxe-Antuñana, Javier Valenzuela. Barcelona: Anthropos Editorial.

Lyons, J. (1997). Semántica lingüística: una introducción. Barcelona: Paidós.

Mattelart, A. (2002). Historia de la sociedad de la Información. Edición revisada y ampliada por el autor. Barcelona: Paidós. 
Moreiro, J. A. (2007). "Evolución paralela de los lenguajes documentales y la terminología". La interdisciplinariedad y la transdisciplinariedad en la organización del conocimiento científico. Actas del VIII Congreso ISKOEspaña, León, 18-20 abril, 29.

Moreno Fernández, F. (2009) Principios de sociolingüística y sociología del lenguaje. $4^{\mathrm{a}}$ ed. Corregida y actualizada. Barcelona: Ariel Letras.

Naumis Peña, C. (2013). "Subject Indexing Trends in Libraries of the National Autonomous University of Mexico (UNAM)". Cataloging and Classification Quarterly, vol. 51, núm. 5, 491-509. Disponible en: <http://dx.doi. org/10.1080/01639374.2012.756094>

Pettee, J. (1946). Subject Headings: the History and Theory of the Alphabetical Subject Approach to Books. New York: Wilson Company.

Rojas, P. (2000). "La ética del lenguaje: Habermas y Levinas". Revista de Filosofía, $3^{\text {a }}$ época, vol. 13, núm. 21, 35-60.

Siurana, J. C. (2009). La sociedad ética: indicadores para evaluar éticamente una sociedad. Cánoves: Proteus.

Yule, G. (1998). El lenguaje. Madrid: Cambridge University Press. 


\title{
La ética en el desarrollo de la ciencia bibliotecológica
}

\author{
Rosa MARÍA MARTÍNEZ RIDER \\ Adriana Mata Puente \\ EduARdo Oliva CRUZ \\ Universidad Autónoma de San Luis Potosí, México
}

\section{INTRODUCCIÓN}

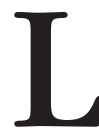

a ética es un tema muy presente en el siglo XXI, frecuentemente se alude a los casos de plagio o falsificación de información; y a las facilidades que brinda el acceso a las tecnologías de información y comunicación, donde se copia y se pega un texto, una imagen, un sonido o un video sin dar el crédito correspondiente a sus autores.

En particular, los investigadores dedicados a la bibliotecología deben cuidar los aspectos éticos, porque una parte fundamental de su formación se basa en el respeto a la autoría y los derechos editoriales.

La ética es un componente en la construcción de la disciplina y sus resultados favorecen a los usuarios de distintos sectores sociales para resolver los problemas de información, en el contexto de la globalización y su dinámica, con un panorama de transformaciones súbitas y hasta impredecibles.

La ética da cuenta de los valores y la responsabilidad social de los investigadores en varios aspectos, tanto en el proceso como en el rendimiento o los productos que se obtienen, en beneficio del gremio, la sociedad y el progreso de la disciplina. 
Uso ético de la información...

A continuación se presentan algunas reflexiones en torno a este tema, como factor de credibilidad y reconocimiento a la evolución del binomio información-sociedad.

\section{LA ÉTICA COMO FACTOR DE LA CONSTRUCCIÓN DEL CONOCI- Miento EN Bibliotecología}

Como toda ciencia, la bibliotecología, se desarrolla a partir de su objeto de estudio, donde la investigación se posiciona en las perspectivas epistemológicas, teóricas, metodológicas y en un quehacer científico normado por reglas éticas en la recolección, análisis y la interpretación de datos, así como en el crédito a la autoría de los trabajos que se consultan.

Se abordan temas con incremento en las posibilidades y opciones de distintas lecturas de los problemas de información (Figura 1).

Figura 1. Elementos que configuran la investigación bibliotecológica.

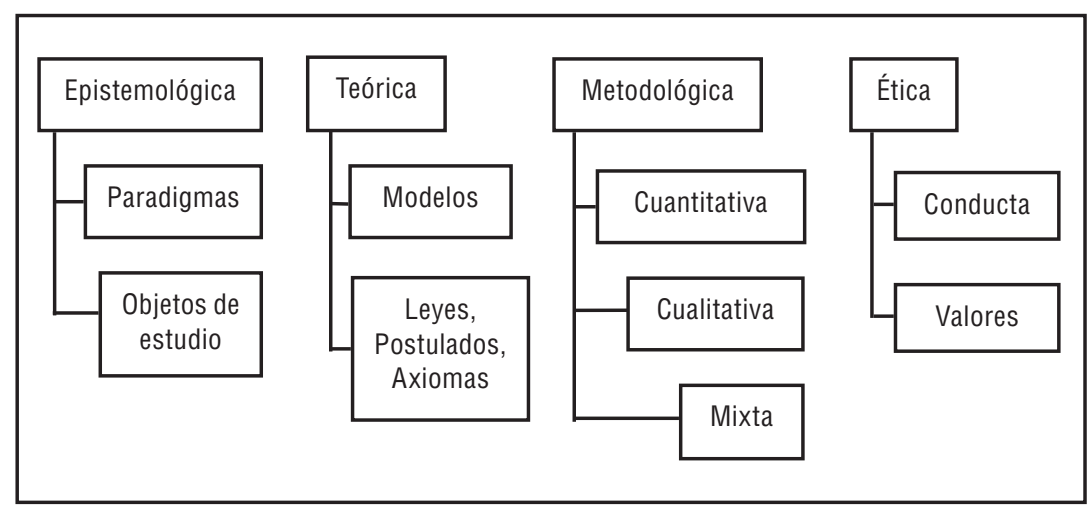

Fuente: Elabotración propia

En relación con el objeto de estudio de las ciencias sociales, Bravo, Díaz y Michel (1980) analizan la construcción desde tres perspectivas, a partir de los trabajos de Durkheim, Weber y Marx para acotar las diferencias epistemológicas: 
a. La posición empirista, con el ángulo científico, donde los rasgos son la neutralidad y la ruptura con el conocimiento del sentido común, con las ideologías y con los valores.

Aquí se consideran los hechos sociales como cosas independientes de la subjetividad de los investigadores.

Se ilustra con el trabajo de Emile Durkheim sobre el suicidio, explicado mediante fenómenos sociológicos, externos a la psicología del sujeto investigado, con lo cual, se enfoca a darle carácter de ciencia a las disciplinas sociales.

b. La postura relativista propuesta por Max Weber, que coincide con los planteamientos de Durkheim en el aspecto cientificista de la investigacion, pero no en la neutralidad, porque la ciencia se hace a través de los investigadores con su propia subjetividad (creencias, intuiciones, intenciones, etc.).

Incorpora el juicio de valor, aunque aclara que el hecho social se expone objetivamente y la cientificidad se da con un esquema metodológico.

Weber propone realizar el trabajo de indagación con un tipo ideal (fragmento de la realidad) y no separar al investigador del proceso de investigacion.

c. La postura de la praxis se funda en el trabajo de Marx, quien estructura las bases del método histórico-dialéctico, en donde se deshecha la ideologia, se recuperan los factores multidimensionales de los contextos (políticos, económicos, culturales) y se concibe una totalidad de procesos históricos transversales a cualquier realidad, con la finalidad de lograr la transformación social.

En estas investigaciones se destacan los contrastes, las contradicciones y las desigualdades sociales, así como el conflicto y la lucha de clases.

Como producto, se obtiene la explicación de las relaciones causa-efecto entre las variables; o los resultados de la interpretación, basadas en la descripción del fenómeno estudiado; o de la comprensión cuando se incorporan los juicios de valor respectivamente. Lo anterior se muestra en la Figura 2, en la siguiente página: 
Figura 2. Posiciones epistemológicas en la construcción del conocimiento.

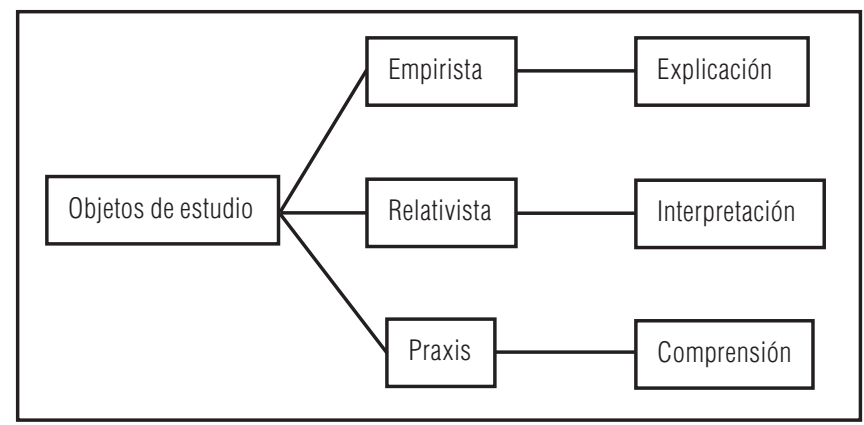

Fuente: Elabotración propia

Estos panoramas tienen un fundamento distinto en la concepción y aplicación de la metodología, en el tipo de conocimiento que se obtiene y han continuado su evolución en el proceso de construcción de los objetos de estudio. Actualmente sustentan algunos principios de los tipos de paradigmas en que se posicionan.

Con respecto a lo anterior, en el ámbito de la región de las Ciencias de la Información, García $(1995,109)$ refiere que en cuanto a la organización del conocimiento, este se basa en la interdisciplinariedad y la diversidad paradigmática. Propone las siguientes tendencias:

a. El Paradigma Conservacionista (pre-científico), sustentado en el modelo de gestión de colecciones y en el concepto de documentos, con la metodología de descripción e inventario, propia de las bibliotecas y los archivos.

b. El Paradigma Fiscalista, que se apoya en un modelo clásico de comunicación y en la medida de la información, que utiliza la metodología experimental centrada en los sistemas de información.

c. El Paradigma Lingüístico, que se sostiene en el sistema lingüístico y los paradigmas léxicos, con una metodología estructural aplicada en los lenguajes documentales.

d. El Paradigma Lógico-Matemático, que se cimenta en los modelos formales, mediante la metodología axiomático-deductiva, a través de los sistemas expertos. 
e. El Paradigma Cognitivo, que descansa en los modelos procesuales-interactivos, con una metodología experimental y de modelización, la cual se traduce en interfaces amigables.

El autor propone que se profundice en las realizaciones sociales obtenidas de los mismos porque son una fuente rica para la interdisciplinariedad.

No obstante, el desarrollo de esta actividad implica una serie de competencias básicas (ortografía, redacción, comprensión de la lectura, matemáticas); genéricas (estadística, tecnologías de información, uso de estilos bibliográficos, etc.); y especificas, en la construcción de los objetos de estudio de las discipinas que conforman las Ciencias de la información.

En resumen, se necesitan competencias científicas, metodológicas, sociales, axiológicas y éticas en la generación de un nuevo conocimiento o en el abordaje de otros ángulos en la difusión de las ideas de los autores, que plantean a su vez nuevas preguntas, la elaboración de nuevos modelos, nuevos conocimientos y diversos enfoques interdisciplinares.

En este caso, la investigación se acota en los límites éticos de la bibliotecología, pues es una ciencia neutral por sí misma y son sus finalidades, usos o aplicaciones las que sustentan los valores que se le asignan para los actores de una realidad social.

En otros ámbitos como el de la ciencia dura, la bibliotecología presenta los mismos problemas éticos, porque la infomación se adquiere, organiza, difunde y conserva; se proporciona con un profesional especializado en el área, que es selectivo y exhaustivo, así como la información debe ser fiable, precisa, pertinente y oportuna. Por ejemplo, en los escenarios médicos para el tratamiento de un paciente o creación de una vacuna.

García (2004, 22-23) expresa las cualidades del conocimiento sustentado epistemológicamente: relevante, verdadero, simple, perfectible, intersubjetivo y sistemático. Este conjunto otorga certezas en la ampliación y expectativas de la disciplina.

A continuación, se muestra la Figura 3 donde se aprecia que la construcción del conocimiento bibliotecológico, a través de las 
Uso ético de la información...

aportaciones teóricas o prácticas, se cimenta en cuatro rasgos fundamentales:

Figura 3.

Principios de la investigación teórica o práctica en el marco de la ética.

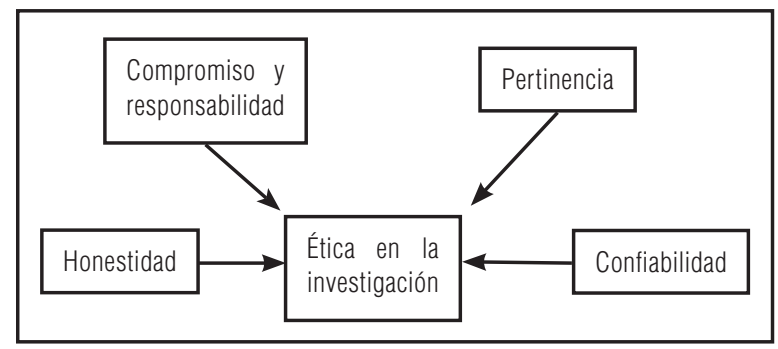

Fuente: Elaboración propia

Esto garantiza que los resultados obtenidos se analizaron, interpretaron y aplicaron con absoluta rigurosidad para que posteriormente sean confrontados o problematizados en otros contextos por los lectores y los colegas.

En este sentido, Mesía señala que "[...] toda investigación influye, directa o indirectamente, sobre los derechos, el bienestar y hasta en la vida privada de los seres humanos" $(2007,138)$ por ejemplo, en la protección de los datos personales de los sujetos sociales que participan en el proceso y abunda, cuando indica que se toman decisiones donde se asumen compromisos morales.

Figura 4. Características éticas de la investigación.

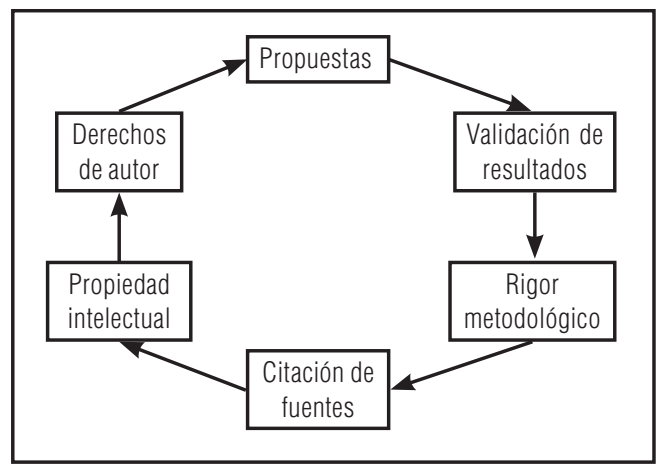

Fuente: Elaboración propia 
De acuerdo con la Figura 4, en la página anterior, se muestra que el conocimiento desde la ética involucra a varios componentes en su realización. Se construye protegiendo los derechos de autor y la propiedad intelectual. Así se contribuye con nuevas propuestas para la solución de los problemas profesionales y con la difusión de las ideas relevantes de un autor.

Con respecto a lo anterior, López (2003, 44-46) hace aportaciones a la evaluación de las citas bibliográficas desde el aspecto cuantitativo y el cualitativo, cuando afirma que estas distribuyen las ideas científicas; identifican las líneas de investigación de los autores; recorren la historia para elaborar el diagnóstico de las investigaciones; y ofrecen elementos en el examen de los resultados científicos. Explica que mediante el análisis, se determina cuales son las citas definidoras de ideas, las citas de autores que se posicionan en una corriente de pensamiento, las referencias al final de la obra, los textos de autores a pie de página, las citas de los documentos, las notas aclaratorias, las citas de agradecimiento y las autocitas de trabajos previos, más allá de las explicaciones que brindan las disciplinas de las metrías de la información.

La valoración de las citas garantiza:

1. Fuentes confiables que se difunden con la seguridad de que son auténticas.

2. La identificación de fuentes primarias, secundarias y terciarias, además de las impresas, audiovisuales y digitales.

3. Que las citas sean correctas y completas.

4. La verificación del sentido y significado de la cita por parte del autor original.

5. La postura del autor en cuanto al contenido de la cita.

Cabe aclarar que Miranda $(2013,715)$ citando a Toller $(2011,85-$ 97) menciona que no hay plagio, cuando se utilizan verdades públicamente reconocidas o ideas que se comparten por los grupos de una rama del saber; cuando se escribe dentro del marco de una escuela de pensamiento que asume ciertas tesis generales; cuando 
por olvido o equivocación se omite citar algún dato no tan relevante, en especial si ya se ha citado antes la obra ajena en la cual se ubica esa idea.

Otras consideraciones que no se tratan de plagios, se relacionan con las autocitas, que desde una tendencia aparecen como autoplagio y desde otra, es necesario retomarlas para reforzar trabajos anteriores; con la barrera del idioma para abordar problemas similares en regiones geográficas y culturales diferentes; con los niveles de especialización; con el acceso a las fuentes físicas en una biblioteca; y con la cantidad de información en Internet o en las redes sociales, que en términos documentales podría generar interés o desinterés.

Sumadas, la teoría, la realidad y las hipótesis en el trabajo de investigación, tanto el rigor metodológico como la transparencia en el análisis de datos recolectados muestran el panorama real de una situación o problema, para que se diseñen estrategias o alternativas de solución.

En el terreno metodológico, González analiza los aspectos éticos en la investigación cualitativa que se extienden a la investigación cuantitativa, expresa que "[...] la práctica científica, como práctica de libertad, es idéntica cuando realizamos investigación cualitativa" $(2002,94)$. No obstante, el conocimiento bajo la interpretación o la crítica responde a la primera, en la cual, se examinan los atributos o propiedades de los fenómenos y no las mediciones.

El autor puntualiza que estos aspectos se relacionan con el valor social o científico, la selección equitativa de los sujetos, la proporción favorable del riesgo-beneficio, las condiciones de diálogo auténtico, la evaluación independiente y el consentimiento informado, entre otros.

Cabe destacar que la IFLA en su Código de ética para los bibliotecarios y otros trabajadores de la información, establece que "[...] la relación entre la biblioteca y el usuario es una de confidencialidad" (2012) dentro del marco del derecho a la información, que se fundamenta en la necesidad de compartirla y difundirla para mejorar la calidad de vida de los ciudadanos del mundo. 
Finalmente, se produce el trabajo unidisciplinar, multidisciplinar, interdisciplinar e intradisciplinar, con enfoques distintos de un solo problema.

\section{CONSIDERACIONES FINALES}

El papel de la ética coadyuva en la construcción del conocimiento, a través de la creación, innovación, ampliación y modificación de las posiciones epistemológicos, teóricas y metodológicas, que definen los resultados de la investigación y las aportaciones a la disciplina bibliotecológica.

El trabajo de referenciar y citar las fuentes contribuye a la expansión de temas y posturas, abriendo un abanico plural de perspectivas, así como a la acumulación histórica del conocimiento, parafraseando a Kuhn.

Los docentes deben crear estrategias didácticas fundadas en la ética para evitar el plagio o la falsificación de información en los trabajos académicos, haciendo hincapié en las implicaciones, los casos y las consecuencias.

La ética en la investigación mejora la toma de decisiones, la solución de problemas y crea alternativas en el diseño de proyectos para beneficiar los sistemas de información, el servicio al usuario, como un sujeto social en un contexto histórico social, donde las Tecnologías de Información y Comunicación requieren la atención en la elaboración de agendas para disminuir las prácticas de plagio.

\section{BibliografíA}

Bravo, V., H. Díaz Polanco y M. A. Michel. (1980) Teoría

$y$ realidad en Marx, Durkheim y Weber. México: Juan Pablos. 
García Marco, F. J. (1995). "Paradigmas científicos en la recuperación de información". En: Organización del conocimiento en sistemas de información y documentación: actas del I Encuentro de ISKO-España, Madrid, 4 y 5 de noviembre de 1993. España: Universidad de Zaragoza. Disponible en: $<$ https://dialnet.unirioja.es/descarga/articulo/ 2341318.pdf>.

-_—— (2004). Bases epistemológicas del ejercicio profesional. Disponible en: <biblio.colmex.mx/ curso_introduccion_bibliotecologia/Bases $\% 20$ epistemolgicas-GA.MARCO.pdf>.

González Ávila, M. (2002). "Aspectos éticos de la investigación cualitativa”. Revista Iberoamericana de Educación, núm. 29, 85-103.

IFLA. (2012). Código de ética para los bibliotecarios y otros trabajadores de la información. Disponible en: <http://files.sld.cu/cpicm-cmw/files/2012/09/ ifla-codigo-de-etica-para-los-bibliotecarios.pdf $>$.

López Yepes, J. (2003) "El análisis cualitativo de citas como instrumento para el estudio de la creación y transmisión de las ideas científicas." Documentación de las Ciencias de la Información. vol. 26, 4170. Disponible en: <https://revistas.ucm.es/index. php/DCIN/article/view/DCIN0303110041A/19333>.

Mesía Maraví, R. (2007) "Contexto ético de la investigación social". Investigación Educativa, vol. 11, núm. 19, 137-152. Disponible en: <http:// revistasinvestigacion.unmsm.edu.pe/index.php/ educa/article/view/3624> 
Miranda Montecinos, A. (2013). "Plagio y ética de la investigación científica". Revista Chilena de Derecho, vol. 40, núm. 2, 711-726. Disponible en: <https:// repositorio.uc.cl/bitstream/handle/11534/9433/ 000614989.pdf? sequence $=1$ \&isAllowed $=\mathrm{y}>$.

Toller, F. (2011). "Propiedad intelectual y plagio en trabajos académicos y profesionales". Revista la Propiedad Inmaterial, núm. 15, 85-9. Disponible en: <http:// revistas.uexternado.edu.co/index.php/propin/article/ view/3000/2644> 


\title{
Consideraciones éticas en el intercambio de información en las redes sociales académicas
}

\author{
ARMANDO SÁNCHEZ SoTO \\ Instituto de Investigaciones Bibliotecológicas y de la Información, \\ Universidad Nacional Autónoma de México, México
}

\section{INTRODUCCIÓN}

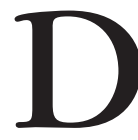

esde hace algunos años el desarrollo tecnológico ofrece nuevas herramientas que facilitan el quehacer cotidiano de los científicos y los investigadores; la llamada ciencia compartida ofrece la apertura hacia nuevas rutas tanto en la aplicación de metodologías como en la difusión y la comunicación de los resultados.

La Ciencia 2.0 no es otra cosa que la aplicación de las tecnologías de la web social, también conocida como Web 2.0 o web participativa, dentro del quehacer científico, tomando en cuenta que la característica principal de esta es la del uso de tecnologías abiertas, desde el punto de vista de la arquitectura de la información, hasta la interconexión de servicios; pero sobre todo del trabajo colectivo realizado con algún fin u objetivo a través de las llamadas redes sociales académicas.

Sin embargo, a pesar de que las redes sociales académicas permiten a los científicos cooperar entre sí con protocolos, discusión de temas y preparación de reuniones científicas, incluso hasta para mostrar un poco de sus investigaciones, es necesario puntualizar 
cuáles son las implicaciones o riesgos de compartir una investigación en progreso.

Algunas de las acciones poco éticas más comunes que se llevan a cabo en el uso de las redes sociales académicas pueden ser las siguientes: compartir fotos que atenten en contra de la integridad de otras personas, el robo de identidad, el robo de la propiedad intelectual, las amenazas físicas y verbales, y la participación en actividades fraudulentas, entre algunas otras. En ese sentido resulta pertinente que quien utilice estas redes sociales, reoriente sus criterios en relación a la forma en cómo utiliza las mismas, tomando en cuenta la integridad personal y académica de aquellos con quien tiene contacto.

De acuerdo con lo anterior, en el presente trabajo se presenta un acercamiento a algunos elementos éticos a considerar en el uso de las redes sociales académicas.

\section{LA ÉTICA APLICADA}

La ética aplicada es un campo de la ética muy importante dentro de cualquier ámbito de la sociedad, ya que esta se presenta como una respuesta a la necesidad de analizar cada uno de los aspectos de la vida humana; desde aquellos que tienen que ver con la simple convivencia social, hasta los que se relacionan con la ejecución de las labores propias de cualquier disciplina o profesión.

Molina (citado por Fernández, 2015: 13) dice que "[...] la ética aplicada requiere ser multidisciplinaria por tener como objeto un aspecto especializado de la realidad [por lo cual...] los problemas que se presenten y requieran un análisis ético deberán primero ser estudiados por los expertos profesionales del área en cuestión”.

\section{LA ÉTICA PROFESIONAL}

El ejercicio de cualquier actividad profesional debe de estar orientado, antes que todo, al servicio y este a su vez debe permitir el desarrollo de los distintos aspectos de la realización personal. En 
la ejecución ética de cualquier profesión, se debe tomar en cuenta que cada disciplina genera como tal un bien específico dentro de una sociedad, por lo cual, quienes la ejecuten deben contar con los conocimientos especializados necesarios para ejercerla.

En ese sentido, uno de los aspectos más importantes a señalar en el ejercicio profesional es el que tiene que ver con la necesidad de establecer una convivencia y un intercambio de conocimientos con el resto de los integrantes de la disciplina que se ejerce (colegas), así como con los afectados o involucrados en la actividad que se realiza (comunidad).

Para lograr lo anterior, la ejecución de una profesión debe contar con ciertas reglas dentro de su ejercicio y aplicación en aras de un beneficio común.

Con respecto a esto, se puede decir que existen distintas virtudes dentro de cada profesionista que pueden ayudarlo en la aplicación de sus actividades profesionales: su vocación, su coeficiente intelectual, su actitud, sus conocimientos y su disposición, entre muchos otros aspectos.

\section{LA ÉTICA EN EL ÁMBITO DE LOS MEDIOS DE COMUNICACIÓN Y LAS REDES SOCIALES}

Ante los retos que tienen hoy en día los medios de comunicación masiva, como la evolución de la información, los hábitos de consumo, la aparición de las TIC, entre otros aspectos; la parte que conlleva a la aplicación de la ética dentro de los mismos a quedado rezagado; actualmente por ejemplo, se cuenta con mucha más información disponible; sin embargo, la calidad de la misma no siempre resulta ser de calidad.

Debido a estos fenómenos, que en gran parte han surgido a causa de la irrupción de las nuevas Tecnologías de Información, se han formulado con frecuencia cuestionamientos acerca del futuro incierto de los consumidores, principalmente en cuanto al uso ético de la forma, el contenido y la distribución de la información. 
Este último aspecto no debe dejarse de lado por ningún motivo, ya que no se debe olvidar que los medios de comunicación, incluidos por supuesto las redes sociales, están dirigidos a las personas ya sea de forma individual o institucional, por lo que en su uso y aplicación se debe siempre de buscar aquello que coadyuve al desarrollo y realización del ser humano, así como del bien común.

\section{Los Colegios invisibles y SU Evolución a la Ciencia 2.0}

Hasta hace algunos años la forma de comunicación e intercambio de información entre los profesionales y científicos de un área determinada, más allá de los canales formales (congresos, seminarios, conferencias, cuerpos colegiados), se daba dentro de los denominados colegios invisibles. Esta forma de comunicación informal hasta entonces actuaba tanto como red de comunicación e intercambio de información, como foro de educación y socialización de los nuevos científicos que comenzaban su trabajo en una línea concreta de investigación.

Sin embargo, sería con la irrupción de la TIC cuando esta forma de comunicación entre científicos y profesionales, vería transformada su forma de uso y consumo de información.

Con respecto al uso de la web y algunas de sus herramientas como los blogs, se ha transformado de manera radical la forma de comunicación dentro de estos colegios, ampliando de manera considerable el espectro de comunicación e intercambio de quienes las integran, pasando de ser meros receptores a participantes de los datos y el conocimiento que circula dentro de su entorno científico y laboral.

El uso de los blogs dentro de los colegios invisibles tiene mucho que aportar en un mundo donde la actualización de los datos, la retroalimentación de lo que se debate y los resultados de lo que se concluye, son la esencia del contexto en el que se actúa. En relación con lo anterior, se puede decir que la blogosfera, definida como un conjunto interactivo de personas que de forma libre comunica sus ideas a través de un blog, no difiere del todo del 
concepto tradicional que se tiene del colegio invisible, con personas interesadas en un tema que difunden y absorben los comentarios de otros, interesados en el mismo, e influenciados por unos pocos (García, 2007: 24).

Con el uso de los blogs, los científicos y los investigadores intercambian sus ideas y resultados, antes de darlos a conocer por los canales de comunicación tradicionales (revistas, libros, conferencias entre otros); en su lugar se valen de reuniones virtuales, chats, listas de discusión y wikis. Aunado a lo anterior, una vez que estos trabajos son publicados, es habitual que quienes los crean los depositen en repositorios y archivos abiertos, de modo que permanezcan accesibles de modo gratuito durante un largo tiempo para que puedan ser consultados.

Las justificación de su uso, además de las más comunes, como las largas esperas de publicación de los artículos, se encuentran en la retroalimentación y crítica casi instantánea que los autores reciben al exponer de este modo sus trabajos.

\section{Ciencia 2.0 o Ciencia compartida}

Desde hace algunos años el desarrollo tecnológico ofrece nuevas herramientas que facilitan el quehacer cotidiano de los científicos y los investigadores; la llamada ciencia compartida ofrece la apertura hacia nuevas rutas tanto en la aplicación de metodologías como en la difusión y la comunicación de los resultados. A este cumulo de beneficios se le conoce también como Ciencia 2.0.

La Ciencia 2.0 no es otra cosa que la aplicación de las tecnologías de la web social, también conocida como Web 2.0 o web participativa; dentro del quehacer científico, tomando en cuenta que la característica principal de esta es la del uso de tecnologías abiertas, tanto desde el punto de vista de la arquitectura de la información, como de la interconexión de servicios; pero sobre todo del trabajo colectivo realizado con algún fin u objetivo.

La web social o Web 2.0 llegó al mundo científico para introducir cambios significativos en los entornos de trabajo. Como ya se 
dijo anteriormente la principal característica de la web social es la participación, en ese sentido la ciencia 2.0 permite que las personas se relacionen de manera fluida, en donde los datos y los resultados puedan ser compartidos de forma abierta.

De acuerdo con Merlo et al. $(2011,5)$ las formas más comunes en las que la web social se aplica a la investigación son las siguientes:

- Para compartir la investigación: La web social ofrece los recursos necesarios para que los investigadores compartan su trabajo, ya sea en una fase inicial o bien en una fase de crítica. Para ello, existen diferentes plataformas abiertas para la publicación de contenidos, bien a través de blogs, de portales académicos, de redes sociales o de sitios web especializados con hipótesis y experimentos, de acceso abierto.

- Para compartir los recursos: La ciencia abierta se identifica por la posibilidad de compartir recursos útiles para la investigación, como son referencias bibliográficas, objetos de aprendizaje, enlaces, informaciones o documentos.

- Para compartir los resultados: La Ciencia 2.0 se caracteriza por su actitud abierta para difundir resultados de investigaciones, fundamentalmente a través de blogs, de servicios de noticias, de revistas disponibles en acceso abierto y de archivos abiertos o repositorios.

\section{COMPARTIENDO LA INVESTIGACión}

Dentro de las diferentes opciones que ofrece el método científico, intervienen personas que desarrollan técnicas de experimentación a partir de procedimientos establecidos. En ese sentido, los servicios de la Web 2.0 facilitan el flujo de ese trabajo permitiendo romper con los límites formales dentro de la constitución de los grupos de investigación que integran a las comunidades científicas.

A partir de lo anterior, una de las primeras aportaciones de la Web 2.0, es ofrecer plataformas útiles dentro de la relación de las personas que comparten los mismos intereses científicos, ya que a 
través de distintas herramientas es posible que estos intercambien recursos, datos y documentos. No se trata simplemente de recursos en los cuales se puede conocer el perfil de un investigador y leer sus trabajos, sino que, dado que la principal característica de la web social es la participación, habría que incluir como recursos de ciencia abierta aquellos sitios web creados para compartir de forma efectiva currículos, investigaciones, hipótesis, entre otras cosas.

Empero no se trata de recursos superficiales en donde únicamente se puede conocer el perfil académico de un investigador, o bien tener acceso a la simple lectura de sus artículos publicados; si no el de acceder a ellos para tener una participación activa. En ese sentido el concepto de red social, dentro de Ciencia 2.0 basada en las herramientas de la Web 2.0, debe entenderse como la comunidad científica que emplea el uso de tecnologías participativas para el intercambio de información.

Estas herramientas pueden ser muy variadas, blogs, wikis, redes sociales, laboratorios virtuales, sistemas de enseñanza en línea, servidores de gestión de intranets o la aplicación tecnológica que se considere de mayor utilidad; de acuerdo a las anteriores las relaciones entre científicos e investigadores encuentran un espacio idóneo en las redes sociales, especialmente en las de carácter académico y profesional.

\section{LAS REDES SOCIALES Y SU UTILIDAD DENTRO DE LAS COMUNI- DADES CIENTÍFICAS}

Desde algún tiempo las redes sociales se constituyen como el mejor exponente de la llamada web 2.0 o Ciencia 2.0, distintas personas o entidades hoy en día se relacionan entre sí a través de esta plataforma tecnológica, mediante la cual pueden comunicarse en forma rápida y simultánea, compartiendo con ello recursos de información y documentos de todo tipo. En ese sentido las redes sociales representan una excelente opción para el trabajo de equipo entre los investigadores y los científicos con intereses comunes, ya 
que a través de ellos pueden compartir experiencias, resultados, hipótesis entre muchas otras cosas.

De acuerdo con lo anterior, el desarrollo de las redes sociales también ha abarcado a la ciencia, ya que se han creado plataformas específicas para investigadores, que operan de la misma forma que las redes del uso común, con la diferencia de que en ellas sólo participan personas que realizan de forma regular proyectos de investigación. En ese sentido las redes sociales son excelentes laboratorios virtuales, ya que ofrecen todos los servicios que un grupo de investigación demanda: sistemas de comunicación, medios para compartir recursos, almacén de documentos y foros de discusión.

Las facilidades que ofrece este tipo de red social a los investigadores y científicos para colaborar y difundir conocimientos e información, siempre será de utilidad en aquellos casos precisos en los que necesiten obtener retroalimentación sobre un trabajo o investigación determinada.

El valor de las redes académicas y científicas va más allá del ámbito de los investigadores científicos y profesores de universidades o institutos; su importancia puede llegar hasta los estudiantes de licenciatura, maestría o posgrado; ya que estos pueden beneficiarse de las mismas dada la apertura del conocimiento que en ellas se ofrece, así como de la posibilidad de compartir información para que esta sea sometida a un proceso de retroalimentación continua. Sin embargo a pesar de lo anterior es muy probable que quienes resulten más beneficiados, al final sean los propios académicos, quienes a través de las mismas buscan constantemente la promoción de sus investigaciones y la mejora de sus posibilidades de colaboración.

Por otra parte en el caso de los profesionales de la información y la documentación que desarrollan su trabajo en universidades e institutos de investigación, este tipo de red social puede constituir un recurso de información de primera magnitud. Su uso adecuado puede constituir una respuesta a la mejora de los servicios que ofrecen en sus unidades de información. 
Las organizaciones de información que se integren activamente a las redes académicas, tanto nacional como internacionalmente, los servicios de información que se planifiquen, diseñen e implementen, orientados a la investigación, dispondrán de amplias posibilidades de elevar la eficiencia y eficacia en su trabajo para convertir la información en conocimiento nuevo y de gran utilidad. (Santana, 2010: 3).

Algunas de las redes sociales académicas de mayor uso en el mundo son las siguientes:

- Academia: se trata de una red social académica de buen éxito que pretende poner en contacto investigadores con los mismos intereses, agrupándolos por entidades, departamentos y temas de interés; además proporciona accesos a textos completos, listas de correo especializadas y ofertas laborales.

- Epernicus: red social que complementa los servicios de pago de esta empresa especializada en software y soluciones web para la investigación, especialmente en el campo biomédico. El investigador puede crear un perfil que le permite comunicarse con otros colegas y crear redes.

- Lalisio: de origen alemán al igual que las demás, pretende ser el punto de encuentro de investigadores de todo el mundo, que puedan crear un perfil bastante completo, semejante a un $\mathrm{CV}$, organizarse en grupos e incorporar textos.

- Methodspace: Web creada por la editorial SAGE como red social gratuita para servir de punto de encuentro sobre los métodos de investigación; permite crear un perfil aunque una buena parte de sus servicios no requieren registrase. Entre sus utilidades destacan sobre otros proyectos, la posibilidad de chatear, el calendario (actualizado) de eventos, los foros de discusión, incluido un servicio del tipo pregunta/respuesta (similar al Yahoo respuestas) o una buena selección de recursos.

- ResearchGate: red social científica en crecimiento que permite, entre otras cosas, la creación de un perfil y el acceso a grupos de interés, foros, o contacto con otros científicos, así como el acceso a literatura afín a los intereses del investigador; 
además contiene una base de ofertas de empleo en el ámbito científico.

- Sciencestage: página con un buscador que da acceso a vídeos, audios y textos de diversas disciplinas, que pueden ser comentados, etiquetados y valorados, además de buscados por su temática; dispone de un sistema de recomendaciones que trabaja a partir de los términos de búsqueda y resultados.

Además de las anteriores existen otras redes de carácter generalista (comunes), que también son útiles para el establecimiento de relaciones entre equipos de investigación. Los siguientes recursos incluyen redes científicas de menor propagación y redes generales de éxito.

- Feelsynapsis: su principal interés es su origen español, por lo que el castellano aparece abundantemente junto con el inglés. Permite construir espacios de trabajo para grupos de investigación a través de los cuales se dispone de foros, se comparten publicaciones, recursos y agendas a trabajar como redes sociales. Además, permite intercambio en tiempo real, con herramientas de videoconferencia.

- Academici: permite la posibilidad de ponerse en contacto con autores de materias afines, principalmente en Ciencias Sociales y Humanidades, publicar e intercambiar resultados y gestionar favoritos. Permite subir imágenes y vídeos, así como crear redes temáticas o sociales (por ejemplo, de alumnos).

- Scispace: de escaso desarrollo tiene su origen en un seminario organizado en la Universidad de Cambridge, su principal peculiaridad es su registro mediante invitación, como Tuenti, aunque ésta se puede solicitar. Permite crear perfiles, comunidades, wikis o servicios de noticias.

- Facebook: de carácter generalista, que por su grado de penetración puede ser de interés para científicos; permite la creación de grupos, por lo que su uso puede ser interesante para reunir a investigadores de todo el mundo. 
- LinkedIn: plataforma creada para intercambiar información y experiencias entre personas con formaciones o trabajos similares; está muy orientada al ámbito empresarial, pero puede ser una buena opción para grupos de investigación, ya que es un servicio muy extendido en todo el mundo.

- Ning: permite crear redes sociales dentro de su dominio; los investigadores interesados en disponer de su propia red, pueden crearla en este servicio de amplia difusión, aunque ya no es gratuito.

- Twitter: aunque no se trata de una red social, sino de un microblog, se puede integrar este servicio dentro del grupo de las redes sociales, ya que permite comunicarse de forma directa con las personas que se han seleccionado, seguir las publicaciones de aquellas personas que interesen y compartir datos, enlaces, documentos, entre otras cosas. Pueden realizarse listas de personas para agrupar especialistas en una disciplina.

\section{ASPECTOS A CONSIDERAR EN EL PROCESO DE COMUNICACIÓN EN LAS REDES SOCIALES ACADÉMICAS}

Aunque, como se mencionó anteriormente, las redes sociales académicas permiten a los científicos cooperar entre sí con protocolos, discusión de temas y preparación de reuniones científicas, tal vez incluso hasta para mostrar "un poco" de sus investigaciones; es necesario puntualizar que siempre habrá investigadores que se muestren recelosos de compartir con todos una investigación en curso, y que en cambio prefieran compartirla solo con colegas muy allegados.

En vista de lo anterior, debe señalarse que los investigadores tienen que considerar siempre cuáles son las implicaciones o riesgos de compartir una investigación en progreso, no sea que durante este proceso salga a la luz información que constituya propiedad registrada o que impida posteriormente al científico en cuestión que pueda publicar su investigación.

Por lo tanto, siempre será razonable que el investigador reflexione cuidadosamente acerca de lo que pretende debatir en línea, 
pues es cierto que las interacciones en la red social son espontáneas; pero en contraste con la mayoría de las interacciones del mundo real, los intercambios en línea siempre quedan registrados, si es que no enteramente públicos.

De acuerdo con Martín (2010, 53), los derechos potencialmente vulnerables en el proceso de interacción y comunicación dentro de las redes sociales académicas son los siguientes:

- Derecho al honor: las redes sociales pueden suponer un nuevo instrumento para perpetrar delitos contra el honor y la imagen personal de un usuario. En este nuevo entorno resulta muy fácil atentar contra el honor de una persona, y lo que es más grave, de forma pública. Basta con una publicación en el muro (en el propio o en el de la persona afectada), un cambio de estado o un tweet para destrozar la reputación de una persona.

- Derecho a la intimidad personal y familiar: es evidente que las redes sociales no son un ámbito exclusivo. Sin embargo, la información que incluye sí puede ser privada, y será responsabilidad del usuario afectado y del buen juicio de sus amigos de su red el publicar algo en el muro o por mensaje.

- Derecho a la propia imagen: el derecho a la propia imagen atribuye a su titular la potestad para disponer de su imagen física impidiendo su difusión salvo que medie su propio consentimiento. Las redes sociales permiten nuevas formas de reproducir la imagen de una persona y hacerla pública de forma instantánea, incluso sin que ésta se dé cuenta.

- Derecho a la libertad: en concreto se distinguen cuatro posibles delitos contra la libertad: la detención ilegal, el secuestro, la amenaza y la coacción. A pesar de que las redes sociales podrían facilitar la comisión de delitos de detención ilegal o secuestro, dado que aportan información valiosa sobre el individuo (localización y hábitos), nos centraremos en los delitos de amenaza y coacción.

- Derecho a la libertad de expresión: Internet es una casa sin tabiques, cada usuario es libre de publicar lo que quiera en las redes sociales, sometiéndose difícilmente al control de la 
plataforma que ofrece el servicio. Ciertas manifestaciones entrarían en colisión con otros derechos de los demás, establecidos en las legislaciones correspondientes (nacionales o internacionales) o en los términos de uso de la red social que se utiliza. - Derecho a la propiedad intelectual: las redes sociales están dando cada vez más importancia a la publicación de contenido gráfico, musical, audiovisual o de cualquier otro género sin que, generalmente, se pida autorización al titular de derechos. Es decir, suponen un vehículo para la reproducción, distribución, comunicación pública y transformación de obras protegidas mediante propiedad intelectual, justamente los derechos cuyo ejercicio exclusivo corresponde al autor, a no ser que se cedan expresamente por éste.

- Derecho a la propiedad industrial: La propiedad industrial se vulnera en primer lugar por el uso sin consentimiento o autorización del titular de la marca, del signo distintivo o el logotipo. Aunque no exista interés de comercialización, el hecho de identificar una marca con una persona puede dañar la imagen de esa marca.

DELITOS INFORMÁTICOS MÁS COMUNES DENTRO DE LAS REDES SOCIALES ACADÉMICAS

Si se toma en cuenta lo manifestado en los párrafos anteriores, se observa entonces que algunos de los delitos más comunes que se pueden cometer en el uso de las redes sociales académicas son los siguientes (Martín, 2010):

- Acceso a información confidencial: las redes sociales como Facebook, son el blanco favorito de piratas informáticos en lo que a robo de información personal se refiere. En un sentido estricto no supone un delito, dado que la lista ya estaba disponible en un directorio que recoge a todos los usuarios cuyo perfil está abierto aunque sea parcialmente. No obstante, que una lista con nombres y números de identificación se organice, 
hace más simple que extraños puedan recopilar direcciones de correo electrónico o datos sobre la ubicación geográfica de los usuarios de Facebook, entre otras informaciones.

- Suplantación de identidad: Ya sea con el objetivo de obtener información confidencial, un beneficio económico, o simplemente el de causar daño, las redes sociales son el medio idóneo para las prácticas de suplantación de identidad. Se puede acceder a mucha información confidencial del perjudicado, así como la de sus amigos en la red social con sólo un nombre y una contraseña.

- Creación de perfiles falsos: Hay hackers que crean perfiles falsos con fines lucrativos e ilegales. Suelen conseguir muchos amigos, para generar confianza entre los nuevos usuarios que agrega al ver que ya es amigo de un amigo. Normalmente buscan agregar a gente del sexo opuesto (si se hacen pasar por una mujer agregan a hombres, y viceversa), y fingen tener una ocupación e intereses similares a sus víctimas, de las que se gana su confianza para llevar a cabo sus actividades delictivas.

- Fraude informático: muchos casos de suplantación de identidad y de creación de perfiles falsos en las redes sociales buscan cometer fraude. En cualquiera de los dos casos, una vez que el usuario del perfil falso consigue la confianza del otro, le explica, por ejemplo, que está en un apuro y que necesita una pequeña cantidad de dinero. Algunos internautas caen en la trampa y transfieren el dinero a una cuenta, esperando que el otro usuario se lo devuelva.

- Daño o sabotaje informático: La mayoría de los mensajes enviados mediante la técnica suplantación contienen un componente de ingeniería social que intenta engañar a la víctima (destinatario del mensaje) para que visite un determinado sitio web o para que descargue un programa en su equipo. En Twitter, uno de los peligros es el acortamiento de las URL. De esta forma, es más fácil enmascarar enlaces a páginas peligrosas.

Y entre las acciones poco éticas en el uso de las redes sociales, Lamb (2010) ha enlistado las siguientes: 
- Compartir fotos o videos que atenten en contra de la integridad de otras personas.

- Robo de identidad.

- Robo en la propiedad intelectual.

- Amenazas físicas y verbales.

- Participación en actividades fraudulentas.

Principales Responsabilidades EN El USO DE LAS Redes SOCIALES ACADÉMICAS

Si se toma en cuenta lo anterior, resulta pertinente tomar en cuenta cual es la responsabilidad que se tiene al hacer uso de las redes sociales no solo del ámbito académico sino también de aquellas consideradas como sociales o comunes.

En ese sentido, sería conveniente regir nuestro criterio en el uso de las mismas de acuerdo con la base de los siguientes principios éticos (Lamb, 2010):

- Proteger tanto nuestra privacidad como la de otras personas.

- Respetar la confidencialidad y confianza que nos brindan los demás.

- Respetar la propiedad intelectual.

- Respetar la integridad física y moral de los otros.

- Responder a los comentarios de forma adecuada.

- Guardar la privacidad de mi información.

- Ser cauteloso al compartir tanto tu información como la de otras personas.

\section{LA ÉTICA EN EL USO DE LAS REDES SOCIALES.}

Como se ha dicho con antelación, el desarrollo de las más populares redes sociales en el ámbito social, incluidas por supuesto las de carácter académico, no es un fenómeno que se encuentre fuera del ámbito de la aplicación de los principios de la ética. 
En consecuencia, resulta necesario considerar el desconocimiento de estos aspectos por parte de quienes las utilizan.

Muchos de estos usuarios se dejan llevar por la facilidad de estar en contacto con las personas dentro de su ámbito de trabajo o social y se registran aceptando ciegamente los términos y las condiciones del sitio web; a partir de ese momento comenzará una cadena de actitudes desafortunadas, tanto por parte del nuevo usuario, como de quienes quieran aprovecharse de su falta de conocimiento. Estas redes cuentan con un perfil público donde el usuario podrá configurar su nivel de privacidad, de esa manera estará en sus manos la cantidad de información que quiera publicar, así como a quienes quiera dirigirla.

El desconocimiento de esas políticas por parte de muchos usuarios es un aspecto común, no es raro buscar alguna persona en el directorio de la red y encontrar todos sus datos sin tener que enviar una petición de amistad y sin que ésta sepa que sus datos están expuestos a todo el público (Buitrago y Lopera, 2010: 8).

En tanto, resulta necesario recalcar que las redes sociales académicas, no son el instrumento de amenaza para la seguridad o confidencialidad de las personas que las utilizan; sino el resto de los usuarios con quienes se establecen contactos e intercambian información, ya que algunos pueden valerse de estas herramientas informáticas para ocasionar daños a la integridad personal e intelectual de quienes las utilizan con un fin adecuado.

Para evitar esto, se debe usar la educación y las buenas costumbres, sobre todo si se toma en cuenta la trascendencia y la importancia de poner al alcance de todos algo tan poderoso como la transferencia y el intercambio de información científica y profesional.

Dentro de este contexto se puede decir que las redes sociales no son una herramienta creada para violar la ley y cometer toda clase de delitos en contra de quienes hacen uso de ellas, por el contrario, son una poderosa interfaz útil para la distribución y el intercambio de información en el ámbito profesional y científico, en donde desafortunadamente algunos de sus usuarios la han convertido en un espacio donde es necesario ser cauteloso con los datos personales así como con lo que se difunde. 
La forma de actuar de los usuarios de las redes sociales académicas, en la mayoría de los casos sale del alcance de los administradores, pues es prácticamente imposible controlar a cada una de las millones de personas que tienen cuentas activas.

El desconocimiento de estos riesgos entre los usuarios, así como de todas las opciones que existen para proteger su privacidad e integridad, es un aspecto preocupante que debe ser atacado profundamente, para evitar el incremento de hechos ilegales en su uso.

Ante este dilema, se hace estrictamente necesario llevar a cabo un mayor enfoque en la aplicación de la ética en el uso de estas redes sociales, así como en la educación y el fortalecimiento de los valores de quienes las usan, por lo tanto, estos usuarios no deben seguir pensando que las limitaciones de la ley son un elemento idóneo para aprovecharse de ellas y tranquilamente declarar su inocencia pese a haber tenido intenciones negativas.

Para tratar de lograrlo, algunos autores puntualizan en el hecho de ejecutar algunas acciones que, aunque aparentemente simples, pueden servir para evitar el mal uso de las redes sociales en el sector académico; entre las cuales Lamb (2010) ha destacado:

- Responsabilidad en la presentación de contenido.

- Hablar en primera persona reflejando nuestro verdadero yo.

- No hablar a nombre de otras personas.

- Pensar muy bien lo que se hace antes de difundir o publicar.

- Responder a los comentarios de forma adecuada.

- Guardar la privacidad de lo que se difunde.

- Ser cauteloso al compartir tanto la información propia como la de los demás.

Asimismo, antes de que una acción poco ética en el uso de estas redes se lleve a cabo, un ejercicio pertinente para evitar tal situación sería reflexionar las siguientes preguntas (Lamb 2010):

- ¿Mi acción conlleva un castigo o penalidad legal?

- ¿Me ayuda a resolver algún problema? 
- ¿Estoy faltando a la privacidad de otros?

- ¿Me molestaría si me lo hicieran a mí?

\section{Conclusiones}

Como ya se ha dicho, gracias a la incorporación de las herramientas de la Web 2.0, las formas de intercambio de información y de comunicación entre los científicos e investigadores, se han visto potencialmente favorecidos.

Hoy en día se vuelve más fácil llevar a cabo reuniones de discusión, intercambiar datos y documentos, compartir experiencias y sobre todo difundir resultados previos de investigaciones en marcha; sin embargo como ya se ha dicho, no todo es tan benéfico como se pretende.

Al presentarse este contexto dentro de un medio de comunicación tan volátil como es Internet, particularmente en el uso de la web 2.0, las posibilidades de plagio, suplantación de identidad, desacreditación de resultados, falsificación de datos y muchos otros delitos informáticos son parte del día a día, no solo en el ámbito científico sino también en las redes sociales convencionales.

Ante tal situación, una de las posibles soluciones para tratar de evitar estos actos ilícitos en el uso de las redes sociales académicas, es el de acudir a la ética, la moral y los buenos principios de quienes hacen uso de las mismas; sobre todo si se considera que son precisamente los científicos e investigadores, quienes gozan de una reputación y una honorabilidad superior al resto de la sociedad común; aunque desde luego, hay que decir que no solo son ellos quienes utilizan estas redes, sino que por algún motivo también lo hacen otros miembros de la sociedad.

En la medida en que esos principios éticos y morales, permanezcan en la conciencia de quienes más utilizan las redes sociales académicas, dados sus intereses particulares; será posible evitar que en lo sucesivo se puedan cometer actos atroces en contra de otros colegas o de cualquier miembro de una comunidad científica o académica determinada, beneficio que no sólo ayudará a los 
mismos sino que además, contribuirá más cada día a la consolidación de estas redes, a fin de poder utilizarse con toda seguridad y certeza de que lo que se escribe, comenta o difunde es de plena confianza.

\section{Bibliografía}

Buitrago Botero, D. M. y R. Lopera Jaramillo. (2010). "Ética en las redes sociales." ETICES boletín de Bioética. Boletín trimestral de la Facultad de Medicina y Departamento de Humanidades, Universidad CES, vol. 2, núm. 4, 1-14. Disponible en: <http:// www.ces.edu.co/index.php/component/joomdoc/ ETICES6ta_edicion_web.pdf/download>.

Codina, L. (2009). "Ciencia 2.0: Redes sociales y aplicaciones en línea para académicos". Hipertext net, núm. 7. Disponible en: <https://www.upf.edu/hipertextnet/ numero-7/ciencia-2-0.html>.

Echavarría Ramírez. A. F. (2010). "Redes sociales académicas... el boom de la web 2.0". e-GATIC Blog del Grupo de apoyo en el uso de TIC para la Universidad ICESI. Disponible en: <http://www.icesi.edu.co/blogs/egatic/ tag/redes-sociales-academicas/>.

Fernández Martínez, J. (2015). Ética y Redes Sociales, un principio moral. México: Universidad La Salle. Disponible en: <www.lasalle.mx/hoy.lasalle.mx/docs/2015/ redes_sociales_etica.pdf $>$.

García, A. (2011). "Internet: Redes Sociales Científicas." Internet $y$ bibliotecas [Sitio web personal] Disponible en: <internetybibliotecas.blogspot.com/2011/04/redessociales-cientificas_03.html> 
García, C. S. (2007). "Blogs los nuevos colegios invisibles: espacios de creación, diálogo y aprendizaje." Cadernos $B A D$. Revista da associação portuguesa de bibliotecários, arquivistas e documentalistas: 'Novos Espaços na Web: Os Blogs na Área da Documentação e Informação', vol. 1, 23-37. Disponible en: <http://www.bad.pt/ publicacoes/index.php/cadernos/article/view/780>.

Lamb. A. (2010). "Everyone doesit: teaching ethical use of social technology". Knowledge Quest, vol. 39, núm. 1, 62-67. Disponible en: <https://scholarworks.iupui.edu/ handle/1805/8634>.

Martín Mompó, P. D. (2010). Aproximación ética y legal a las Redes Sociales. [Proyecto final de carrera, Universitat Politècnica de València. Escola Tècnica Superior d'Enginyeria Informàtica]. España: el autor. Disponible en: <http://hdl.handle.net/10251/16109>.

Merlo Vega, J. A., T. Ferreras Fernández, J. P. Gallo López, A. Angosto Castro, J. A. Maestro Cano y I. Ribes Llopes. (2011). "Ciencia 2.0: aplicación de la web social a la investigación". Workshop Rebiun Proyectos Digitales. Valencia 7 y 8 de octubre. Disponible en: <http:// hdl.handle.net/10251/12054>.

Ochoa, R. (2009). El uso de las redes en el lugar de trabajo. Disponible en: <http://rosauraochoa.com/2009/12/ el-uso-de-las-redes-sociales-en-el-lugar-de-trabajo/>.

Santana Arroyo, S. (2010). "Redes de intercambio científico y académico entre los profesionales en el contexto de la web 2.0". ACIMED Revista Cubana de Información en Ciencias de la Salud, vol. 21, núm. 3, 1-10. Disponible en: <www.acimed.sld.cu/index.php/acimed/article /view/98/47>. 


\title{
La información documental en el cine. Aspectos éticos y generales Una propuesta de trabajo
}

\author{
JOSÉ LÓPEZ YePES \\ Universidad Complutense de Madrid
}

\section{LA ÉTICA Y SU APLICACIÓN EN EL PROCESO INFORMATIVO-DOCUMENTAL}

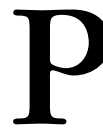
ara el presente artículo, consideramos oportuno utilizar los componentes del proceso informativo tradicional utilizadas por las ciencias de la comunicación social (López Yepes, 2016): sujeto emisor, mensaje, medio y sujeto receptor, como ejes en los cuales basar la ética de las ciencias de la información documental.

Recordemos que la información es el resultado del acto de informar, que informar significa literalmente dar forma a algo y que cuando estamos informando, estamos dando forma a un mensaje de un modo determinado y transmitiéndolo a través de un medio determinado. Tan es así, que el periodista da forma a sus mensajes al modo periodístico y puede transmitirlos a través de medios como prensa, radio, internet, televisión, etc. Por tanto, el periodismo es un modo de informar como también lo son la publicidad, la propaganda, las relaciones públicas, la enseñanza, la ciencia, la literatura, etc. Todos estos modos pueden utilizar diversos medios: la voz, la escritura tradicional o medios de difusión masiva. 
Paralelamente, las ciencias de la información documental (Bibliotecología, Archivología, Museología, etc.) se basan en un proceso informativo en el que se produce la transformación en potencia de mensajes anteriormente producidos en fuentes que se actualizan para producir nuevas informaciones. Así pues, la información documental es un modo de informar susceptible de utilizar diversos medios como los tradicionales documentos (libros, revistas, etc.) y ahora los documentos digitales y el vasto ámbito de internet.

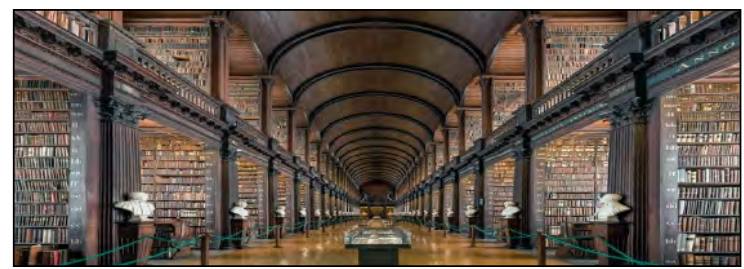

Biblioteca de libros antiguos. Trinity College. Dublín.

Como es evidente, los modos y medios de comunicación —entre los que se encuentran lo que nos competen- han experimentado convulsiones y avances, en conjunto, como integrantes de la denominada sociedad de la información, una sociedad en la que todos estamos inmersos a nivel global, la cual se caracteriza básicamente porque sus miembros poseen y suelen ejercitar con insistencia la manifiesta capacidad de producir mensajes, emitirlos, conservarlos en cantidades ingentes, acceder a ellos y hacerlos navegar en el espacio y el tiempo en un ámbito ucrónico y utópico. Desde esta perspectiva, el estudio de lo que ahora nos compete debe ser hecho sobre todos y cada uno de los componentes del proceso informativo-documental. Habrá, pues, una ética de los sujetos emisores (autor y profesional del documento), una ética del mensaje (el documento), una ética del medio (las unidades de información: archivos, bibliotecas, centros de documentación y museos) y una ética del sujeto receptor (usuario, investigador, lector, etc.). 
En el contexto que nos ocupa, la ética de la profesión informativo-documental se fundamenta en una serie de principios y normas que garantizan el comportamiento honesto de los citados componentes del proceso. En este trabajo los detectaremos en algunas realizaciones cinematográficas.

En el ámbito de las ciencias de la información, las miradas se centran en la responsabilidad del profesional de la información como punto focal. Asimismo, el hecho de que los principios éticos constituyan el pilar fundamental de la práctica profesional resulta una aseveración muy importante en la medida en que estos principios pueden asegurar la verdad en la información; por tanto, la formación ética es básica en la formación técnica de los profesionales. Por otra parte, las bases éticas en la formación se basan en una serie de principios como pensar que una orientación moral ética recta es mejor que unas normas de conducta codificadas y que es preciso desarrollar hábitos morales de la profesión ya que, al decir de Videla, "la información no puede existir sin informador, sin la persona y, por lo tanto, sin su conciencia [...] y que, en definitiva, toda información que realmente lo sea será una información ética”.

De modo concreto, podríamos cifrar los aspectos éticos vinculados al autor del documento y al profesional de la información en los siguientes: el respeto a los derechos a la propiedad intelectual del autor, el mantenimiento de la libertad intelectual, el acceso a las fuentes y el libre flujo de la información, el esfuerzo por evitar la ocultación, manipulación y falsificación de los documentos, y la actualización permanente de la competencia profesional.

En cuanto a la ética del mensaje documentario, ésta se vincula fundamentalmente a la verdad del mismo, lo que es incompatible con los rasgos de manipulación, ocultación y falsificación manifestados más arriba, y con todo lo relacionado con la censura y su eventual destrucción.

Por su parte, el medio o las unidades de información deben cumplir de modo eficaz sus objetivos o, en su caso, contribuir a la consecución de los objetivos de la institución que las mantiene y, en suma, lograr la calidad de sus servicios y mostrar responsabilidad social. 
Finalmente, el receptor, usuario en términos generales, lector o investigador, es sujeto de derechos como la prestación de servicios eficaces, el respeto a su intimidad y la tarea de buscador de información para obtener nueva información o para la toma de decisiones. Consideramos que a esto debe añadirse la actividad de los periodistas en los procesos propios del periodismo de investigación.

\section{BIBLIOGRAFÍA Y FILMOGRAFÍA}

Para la realización de la propuesta que presentamos, nos hemos servido de trabajos relativos a la ética bibliotecaria como el de Bustamante (2007) y otros más anclados en la presencia cinematográfica como los de Gracia Armendáriz (1995), Ontoria (1996), Paz Yanes (2002), Martín Otegui (2009), Laudano y otros (2012) y nuestra reciente publicación sobre la ética del periodismo en el cine (2016). La filmografía en que aparecen testimonios del quehacer documental con mayor o menor porcentaje es muy abundante y nuestro objetivo ha sido trasladar al lector algunos de los filmes donde se representan cuestiones que tienen que ver con los aspectos éticos arriba mencionados. Además, aportamos el minutado de las secuencias de modo orientativo dada la falta de uniformidad del tiempo de duración de las películas según cada fuente de consulta. En suma, los filmes de los que nos hemos servido, y cuyas carátulas mostramos a continuación, por orden cronológico, son los siguientes: 


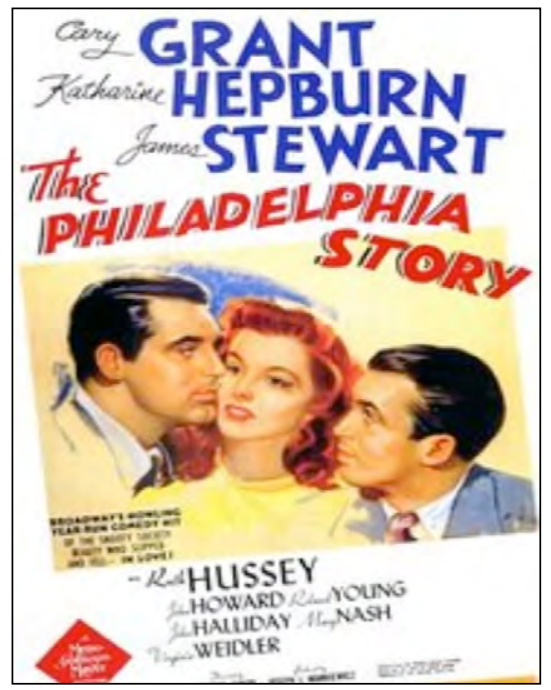

Historias de Filadelfia

Dir. George Cukor (1940)

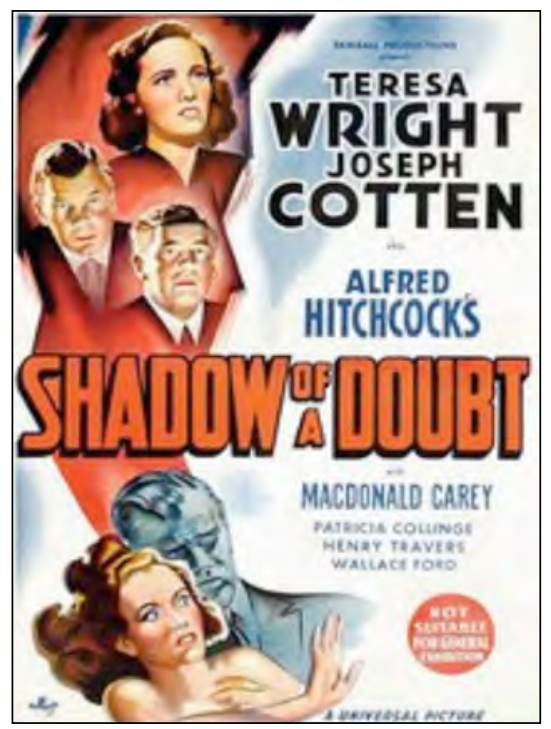

La sombra de una duda

Dir. Alfred Hicthcock (1943)

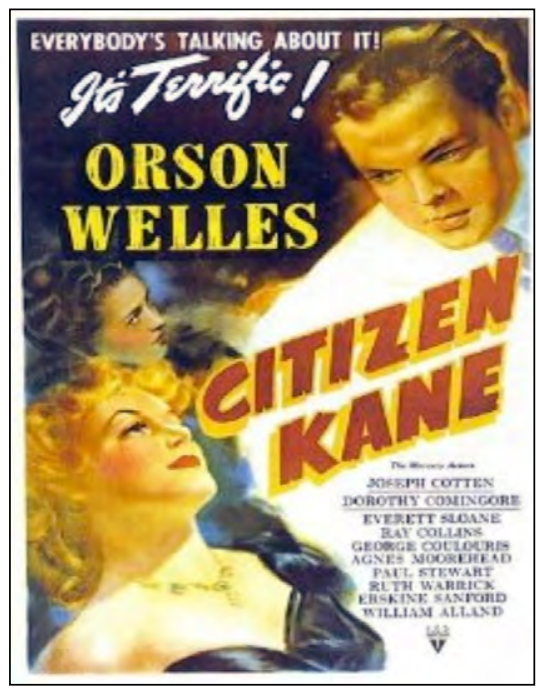

Ciudadano Kane

Dir. Orson Welles (1941)

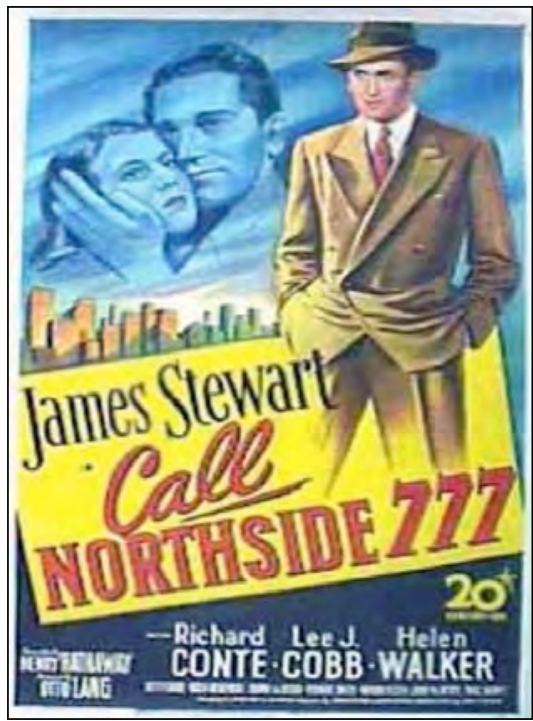

Yo creo en $t i$

Dir. Henry Hathaway (1948) 
Uso ético de la información:...

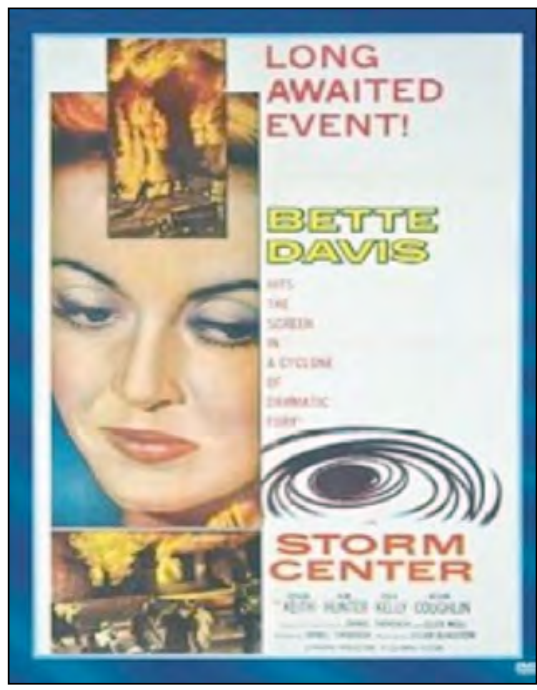

En el ojo del huracán

Dir. Daniel Taradash (1956)

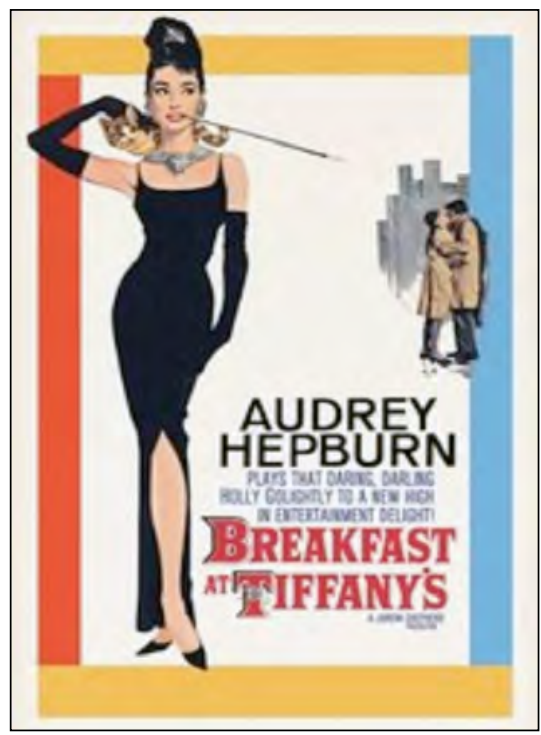

Desayuno con diamantes

Dir. Blake Edwards (1961)

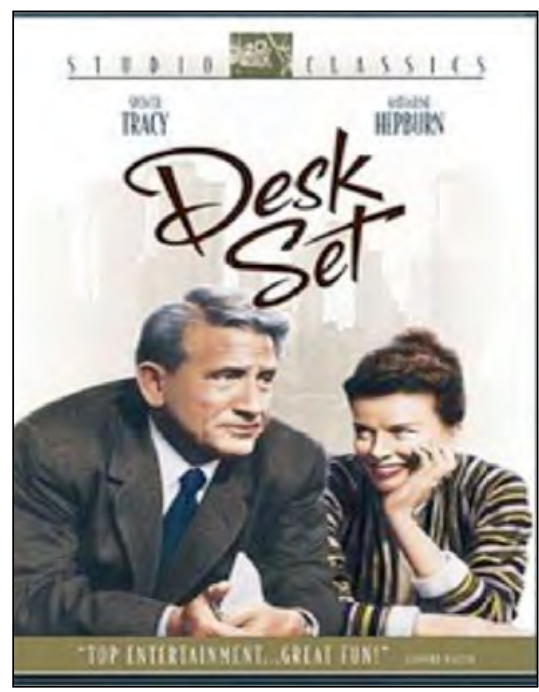

Su otra esposa

Dir. Walter Lang (1957)

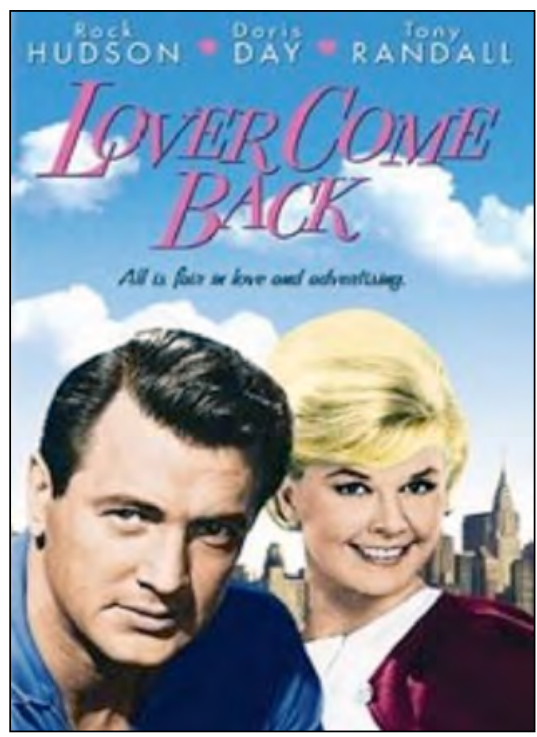

Pijama para dos

Dir. Delbert Mann (1961) 


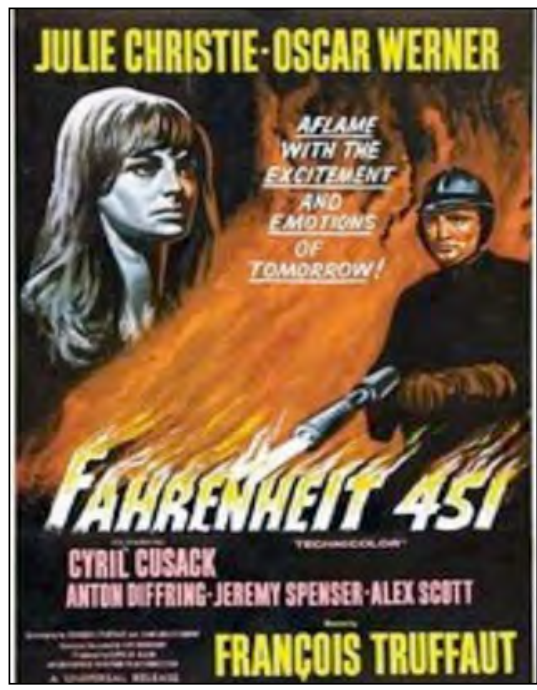

Fahrenheit 451

Dir. François Truffaut (1966)

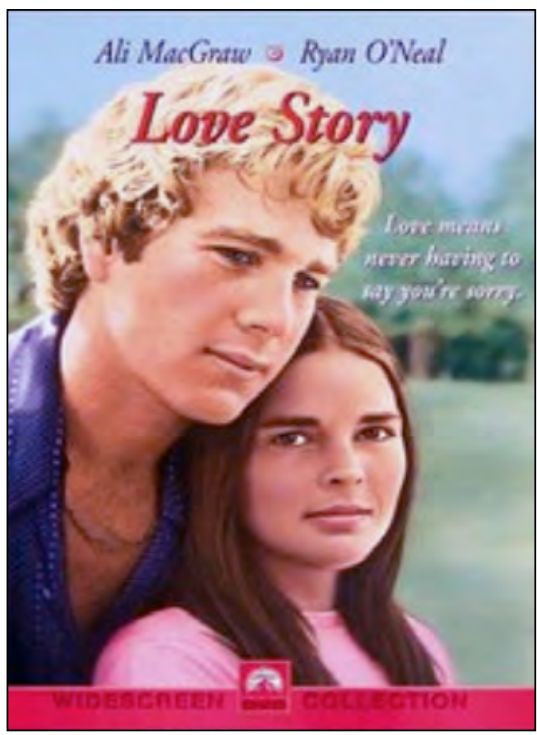

Love Story

Dir. Arthur Hiller (1970)

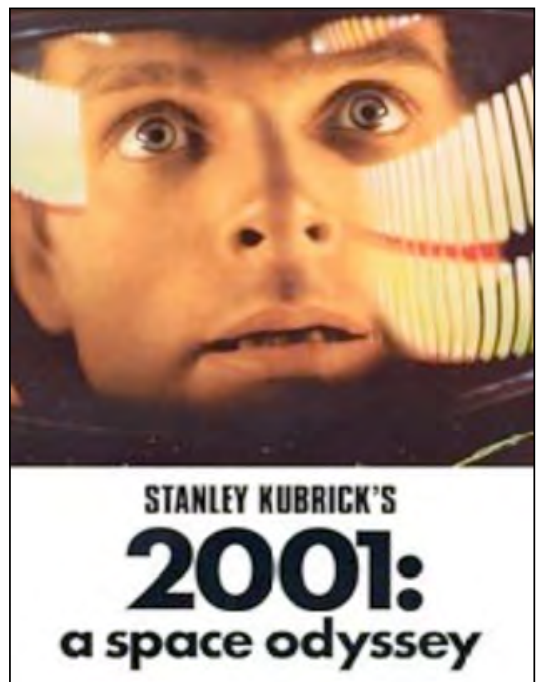

2001: Una odisea del espacio

Dir. Stanley Kubrick (1968)

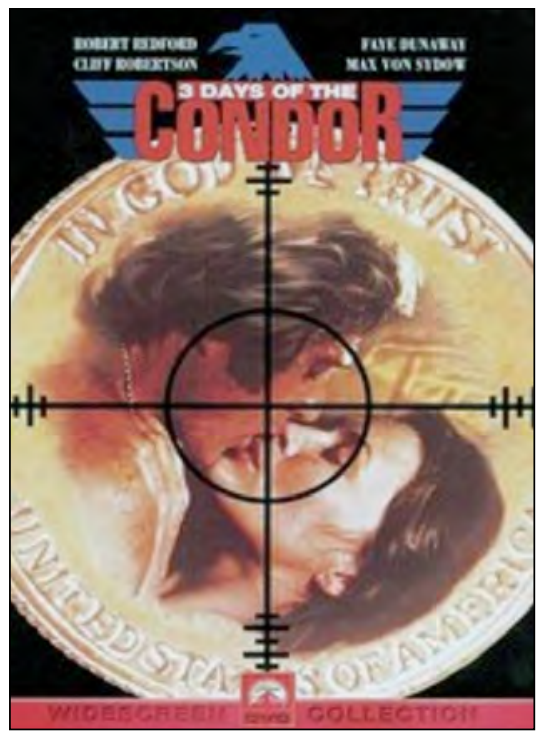

Los tres días del cóndor

Dir. Sydney Pollack (1975) 
Uso ético de la información:...

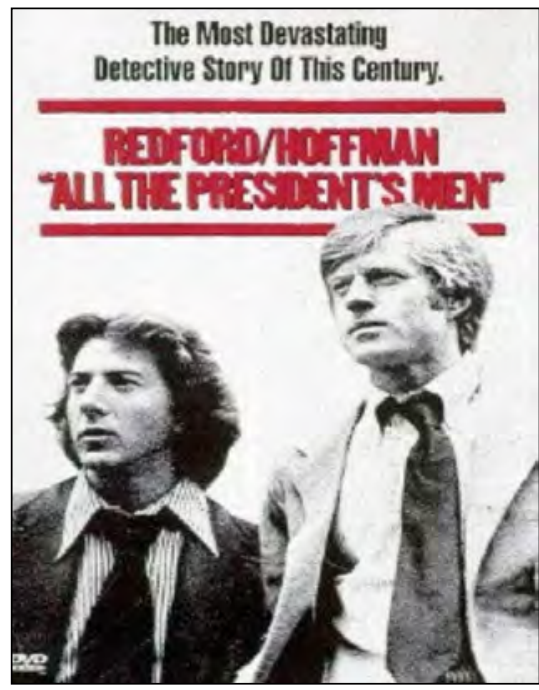

Los hombres del presidente

Dir. Alan J. Pakula (1976)

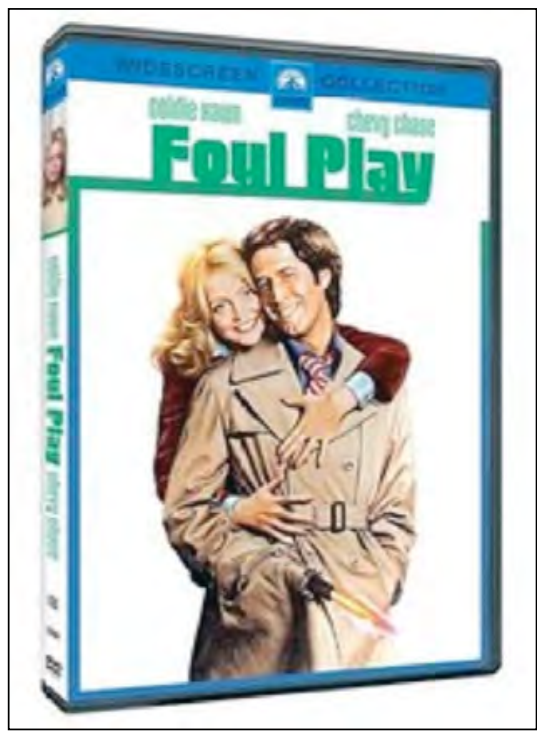

Juego peligroso

Dir. Colin Higgins (1978)

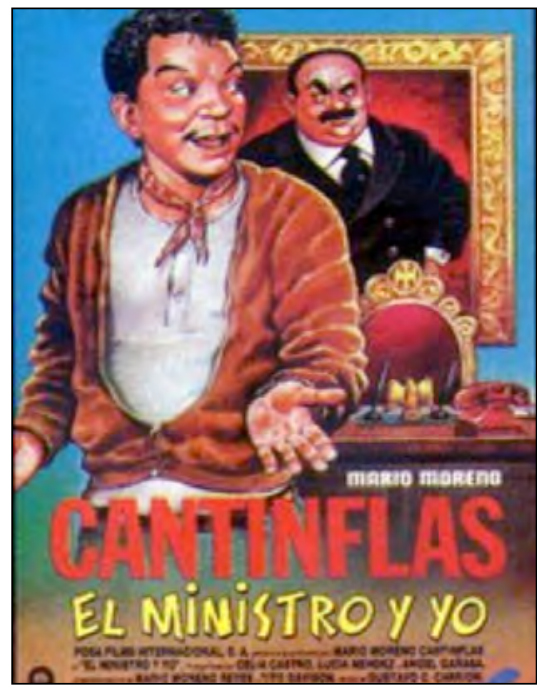

El ministro y yo

Dir. Miguel M. Delgado (1976)

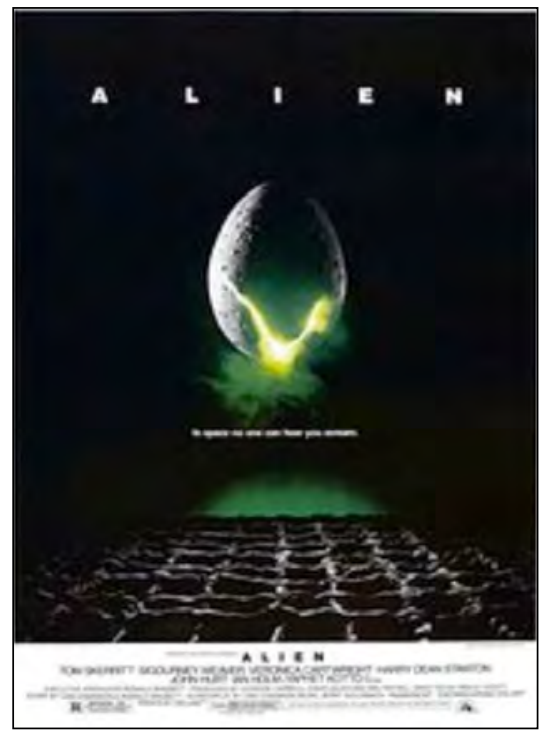

Alien, el octavo pasajero

Dir. Ridley Scott( 1979) 


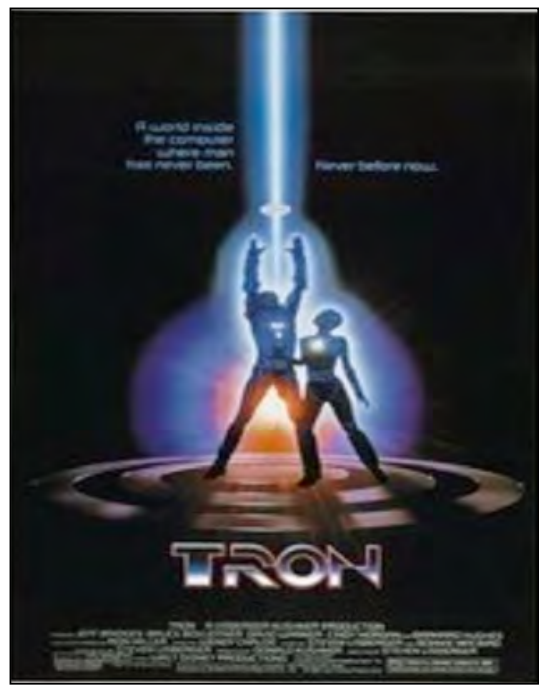

Tron

Dir. Steven Lisberger (1982)

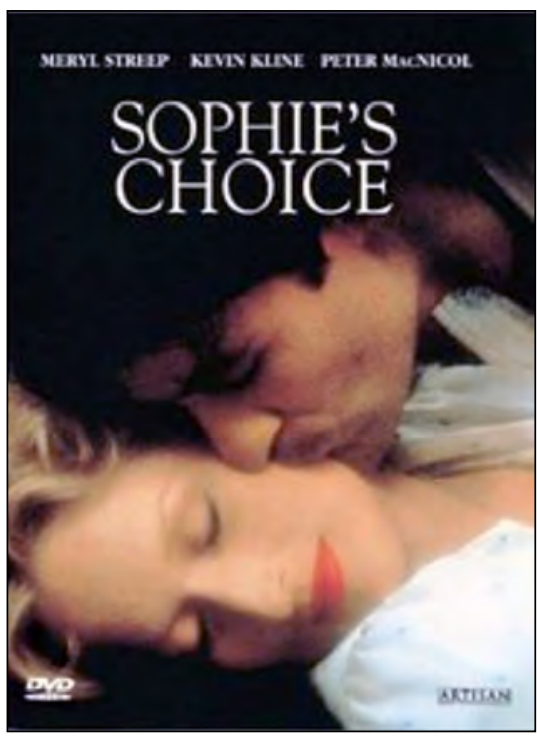

La decisión de Sophie Dir. Alan J. Pakula (1982)

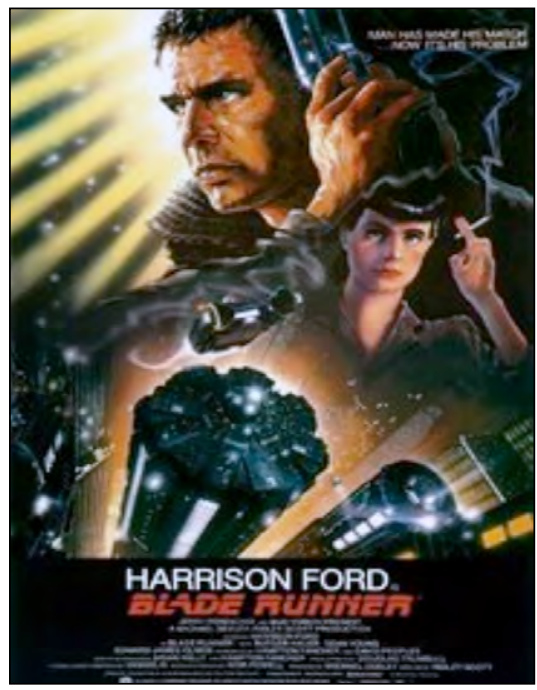

Blade Runner

Dir. Ridley Scott (1982)

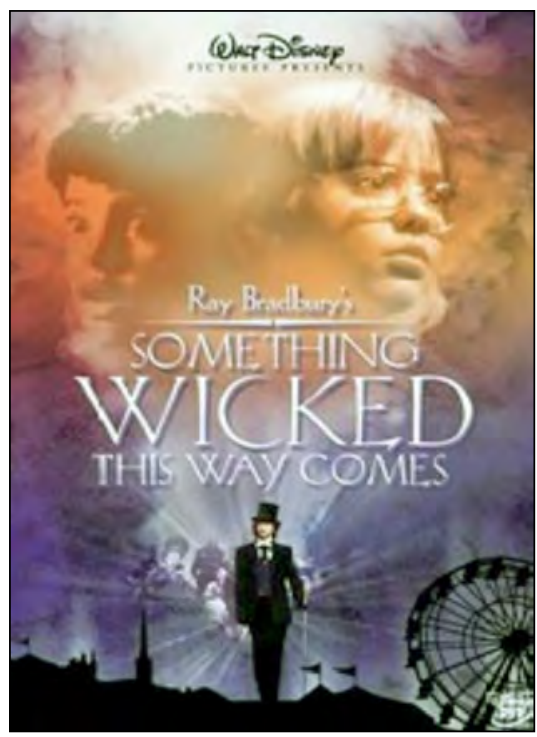

El carnaval de las tinieblas

Dir. Jack Clayton (1983) 
Uso ético de la información:...

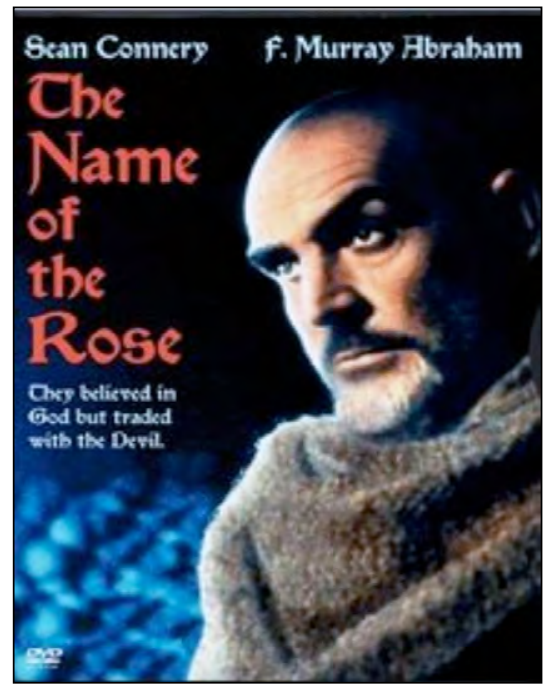

El nombre de la rosa

Dir. Jean-J. Annaud (1986)

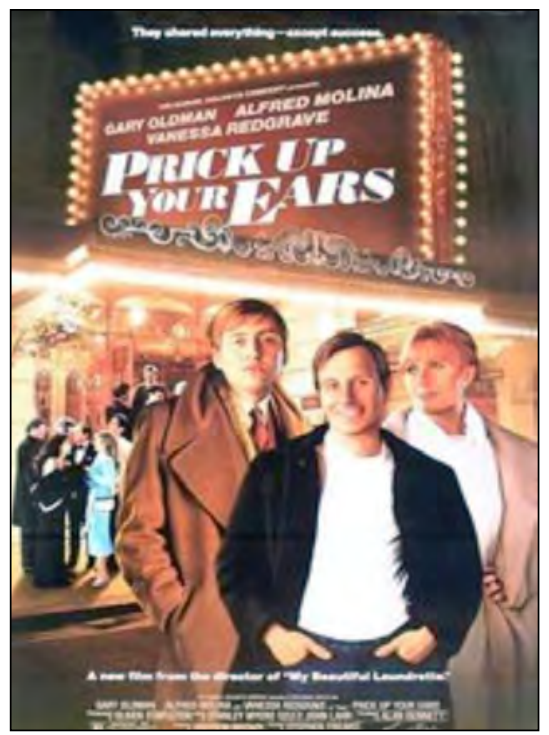

Ábrete de orejas

Dir. Stephen Frears (1987).

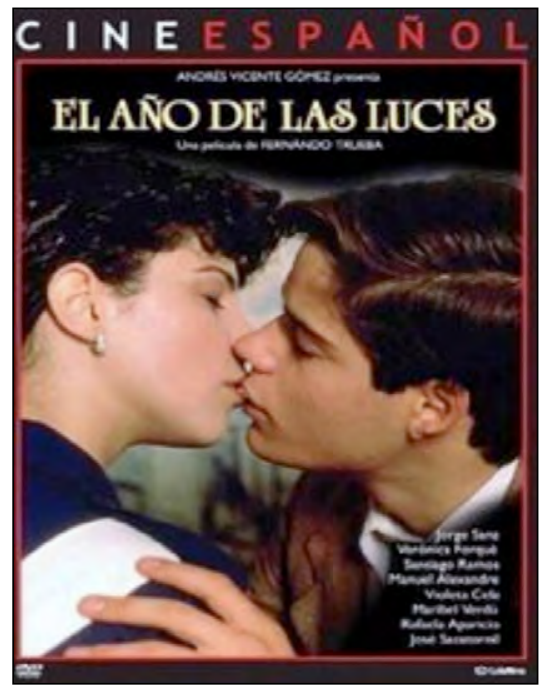

El año de las luces

Dir. Fernando Trueba (1986)

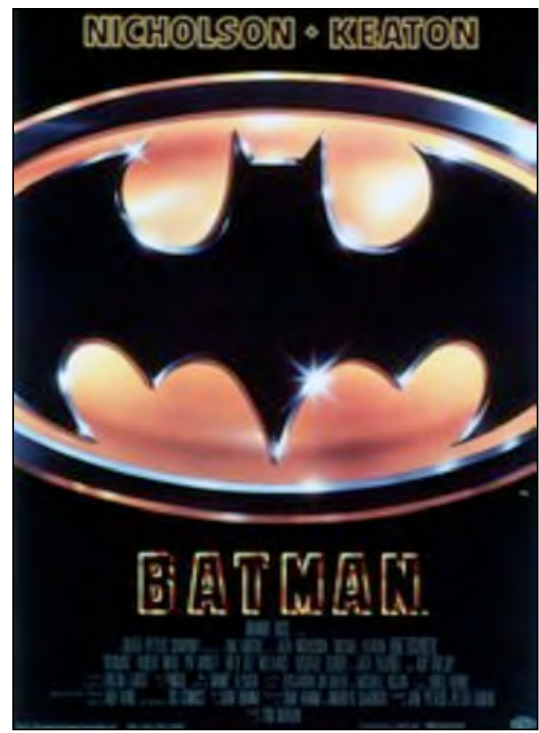

Batman

Dir. Tim Burton (1989) 
La información documental...

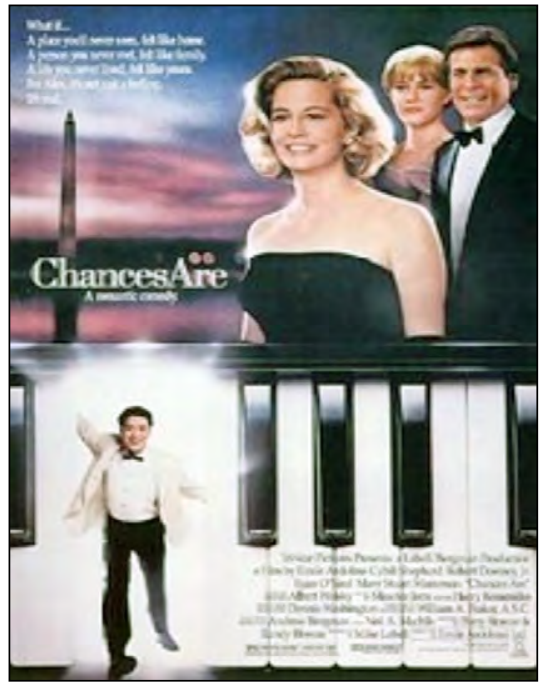

El cielo se equivocó

Dir. Emile Ardolino (1989)

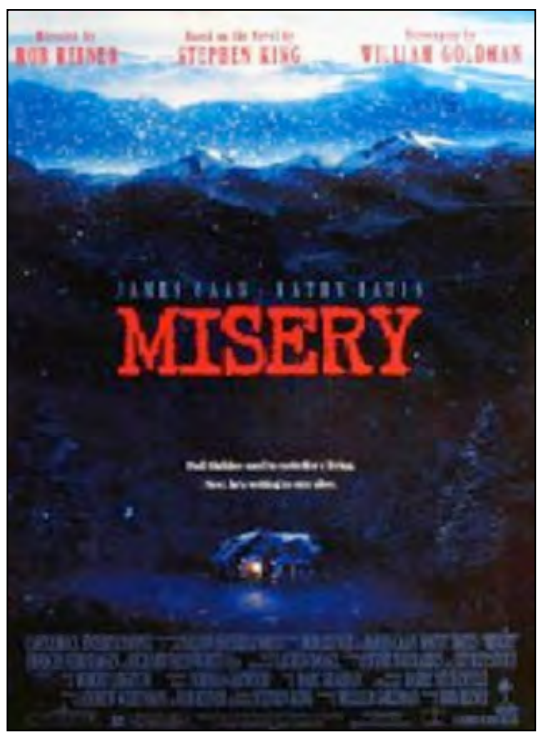

Misery

Dir. Rob Reiner (1990)

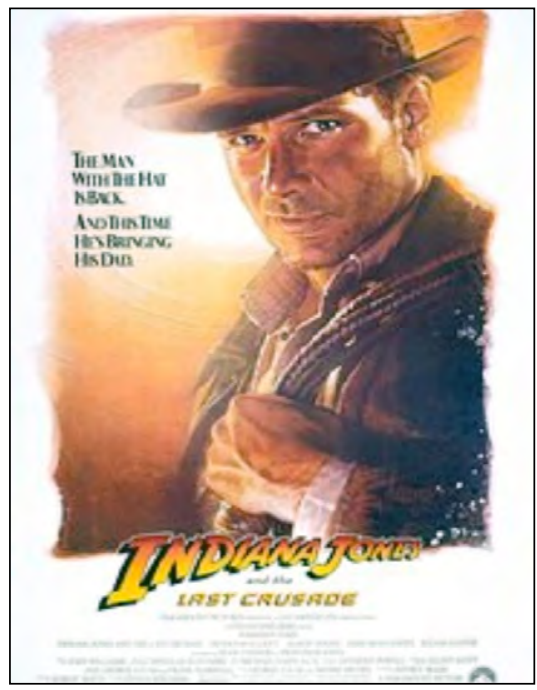

Indiana Jones y la última cruzada

Dir. Steven Spielberg (1989)

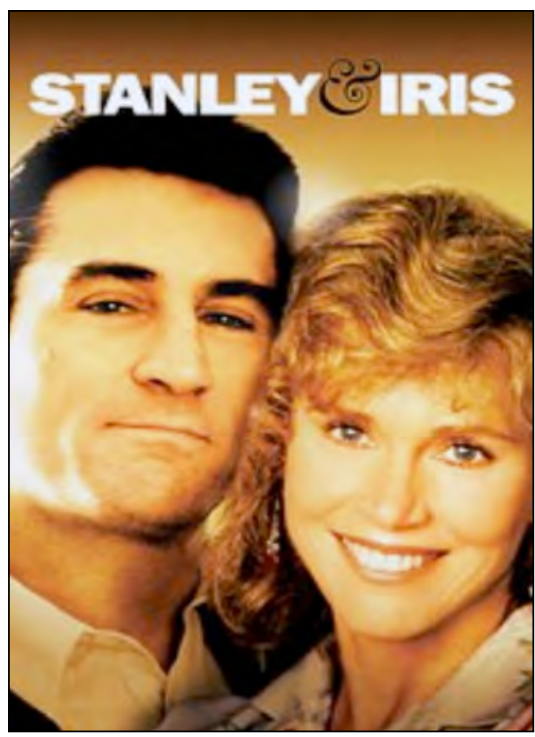

Cartas a Iris

Dir. Martin Ritt (1990) 
Uso ético de la información:...

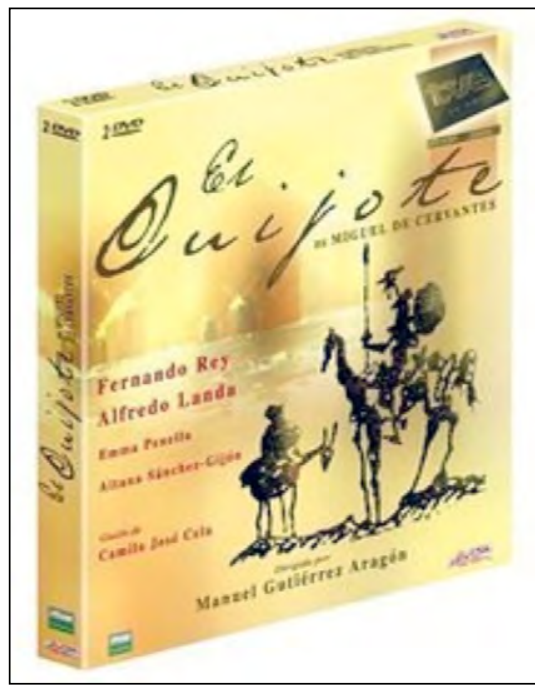

El Quijote de Cervantes (Serie TV)

Dir. Manuel Gutiérrez Aragón (1991-92)

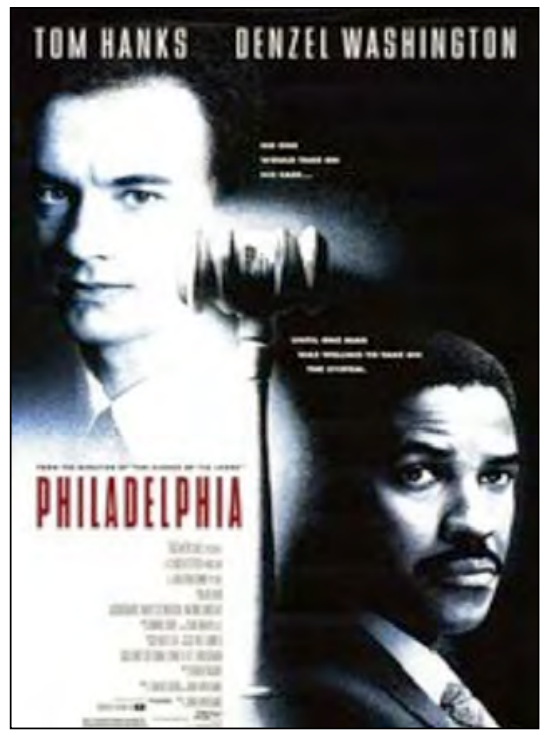

Filadelfia

Dir. Jonathan Demme (1993)

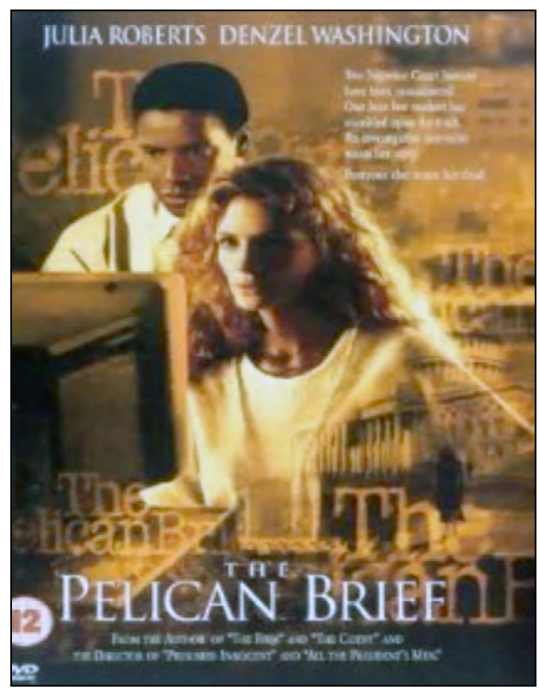

El informe Pelícano

Dir. Alan J. Pakula (1993)

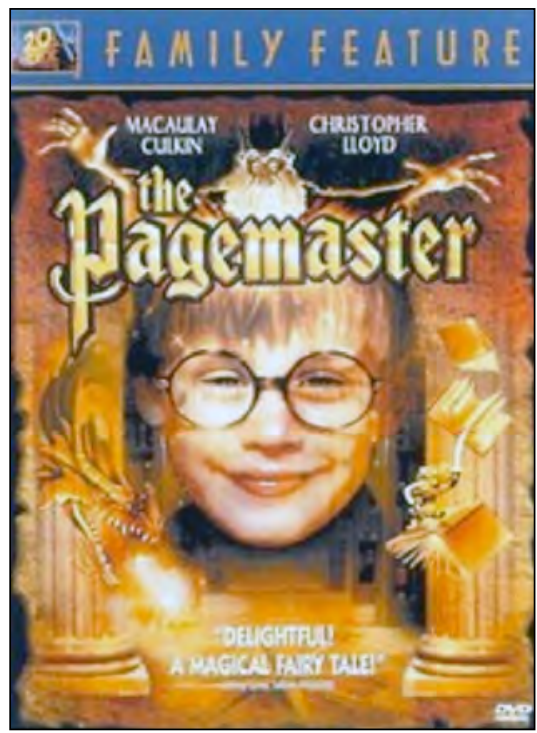

El guardián de las palabras

Dirs. Pixote Hunt y Joe Johnston (1994) 


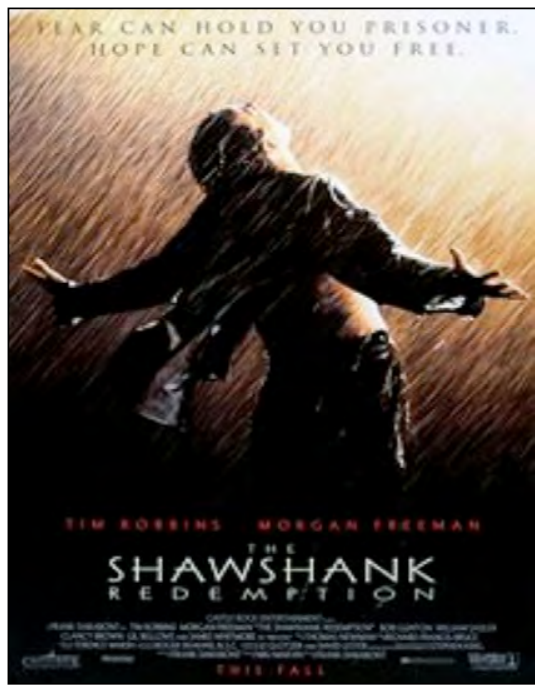

Cadena perpetua

Dir. Frank Darabont (1994)

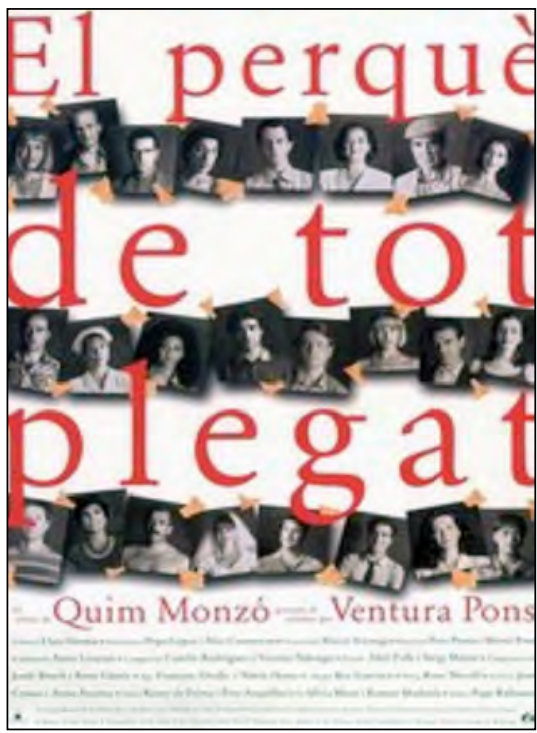

El porqué de las cosas

Dir. Ventura Pons (1995)

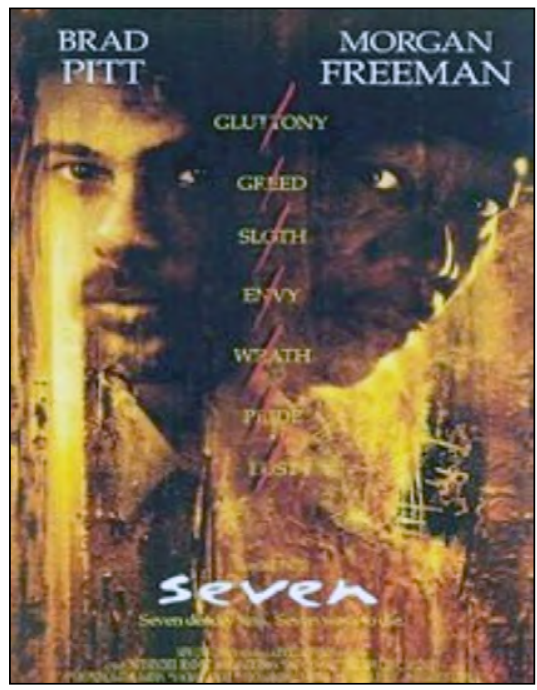

Seven

Dir. David Fincher (1995)

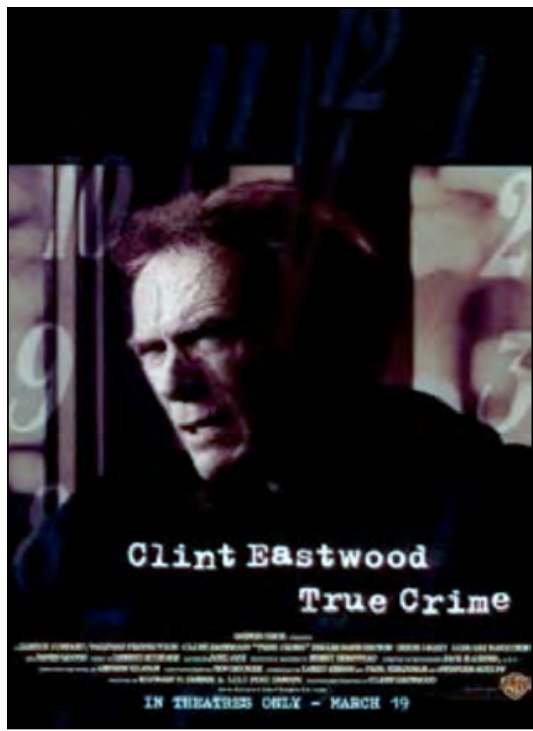

Ejecución inminente / Crimen verdadero Dir. Clint Eastwood (1999). 


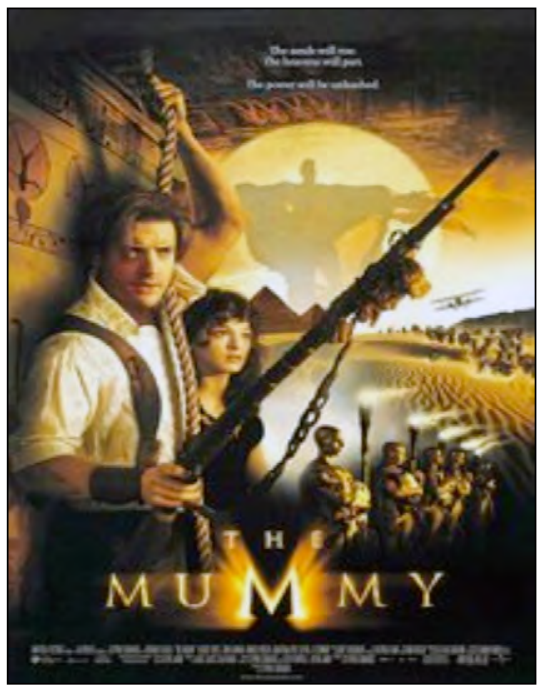

La momia

Dir. Stephen Sommers (1999)

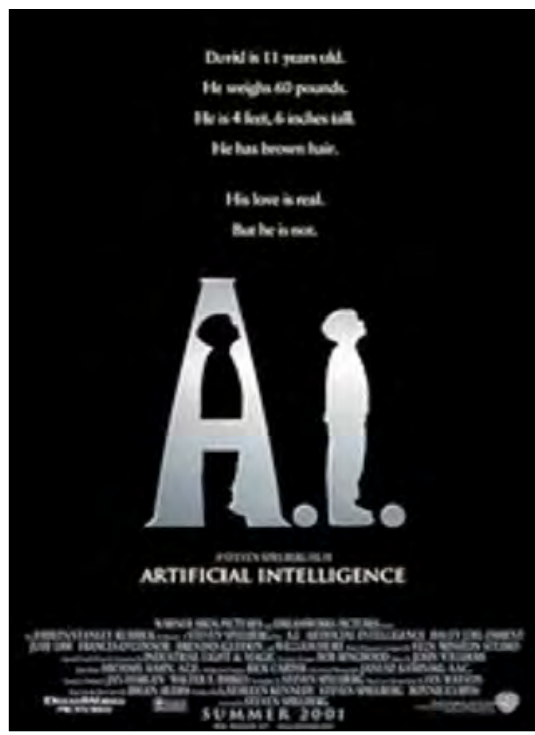

Inteligencia artificial

Dir. Steven Spielberg (2001)

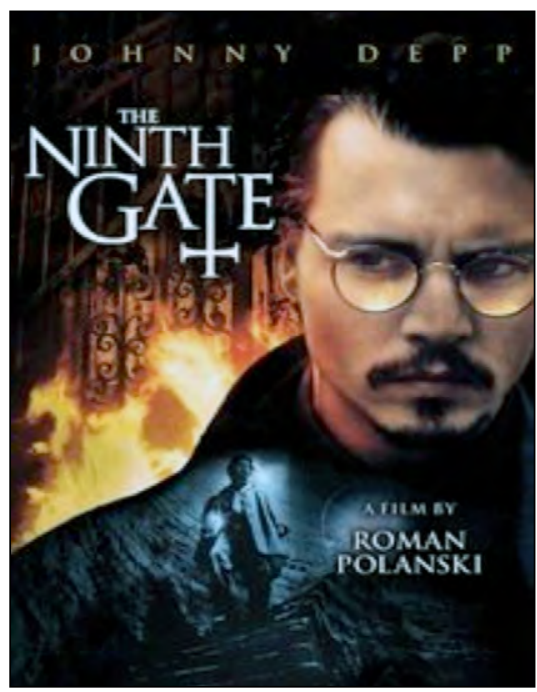

La novena puerta

Dir. Roman Polanski (1999)

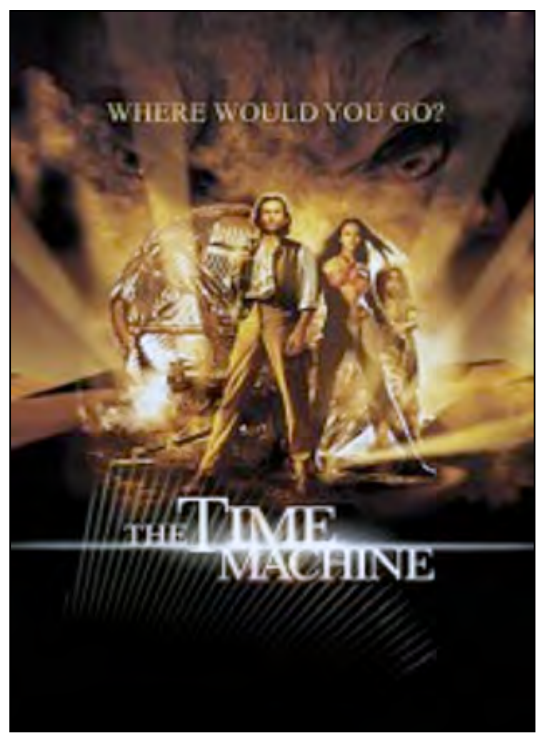

La máquina del tiempo

Dir. Simon Wells (2002) 


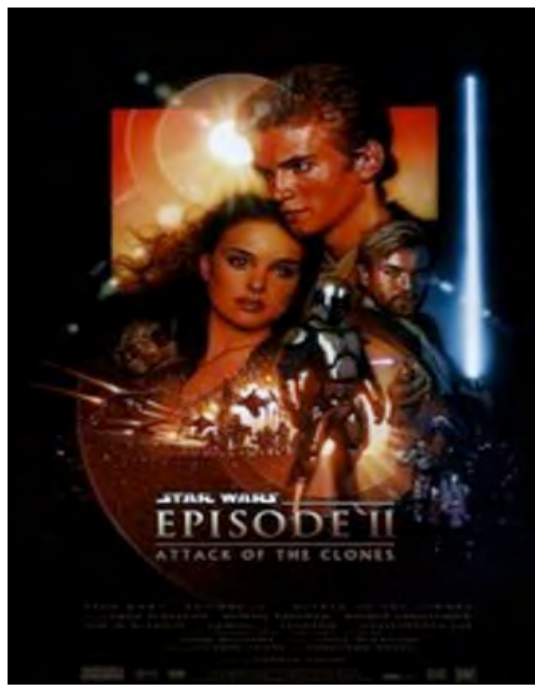

La guerra de las galaxias. El ataque de los clones. Dir. George Lucas (2002)

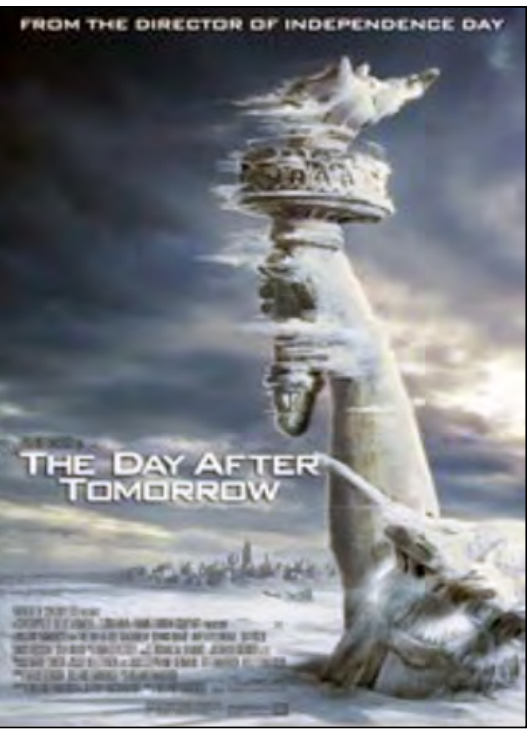

El día de mañana después

Dir. Roland Emmerich (2004)

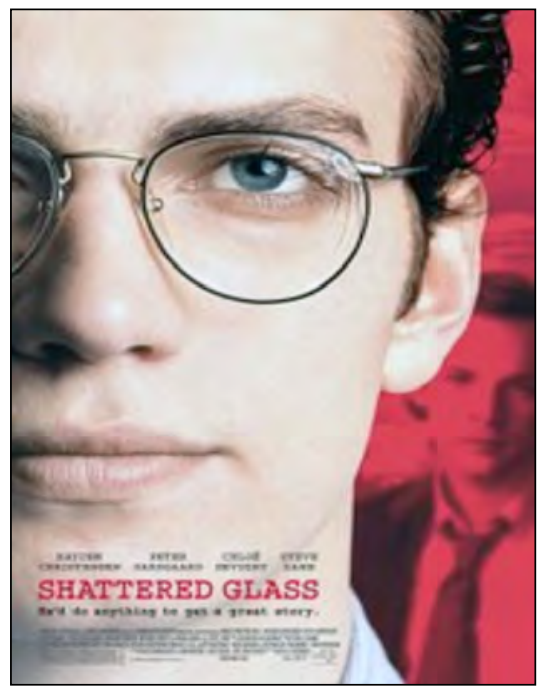

El precio de la verdad

Dir. Billy Ray (2003)

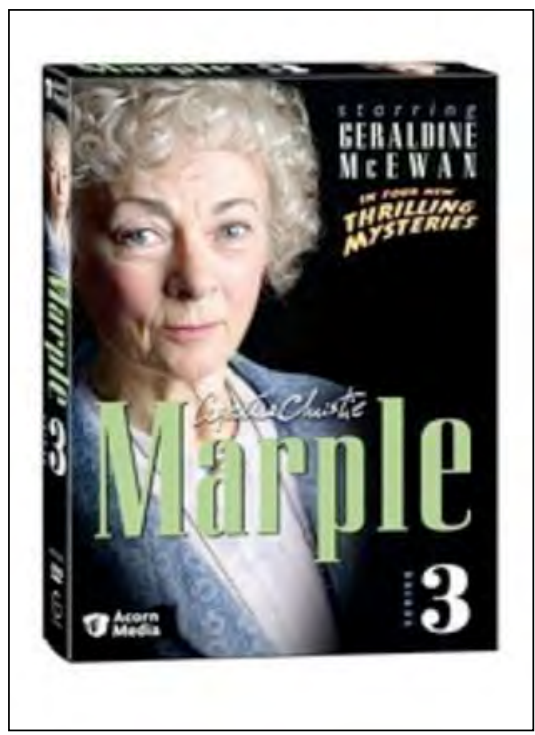

Un cadáver en la biblioteca (Serie TV) Dir. Andy Wilson (2004) 
Uso ético de la información:...

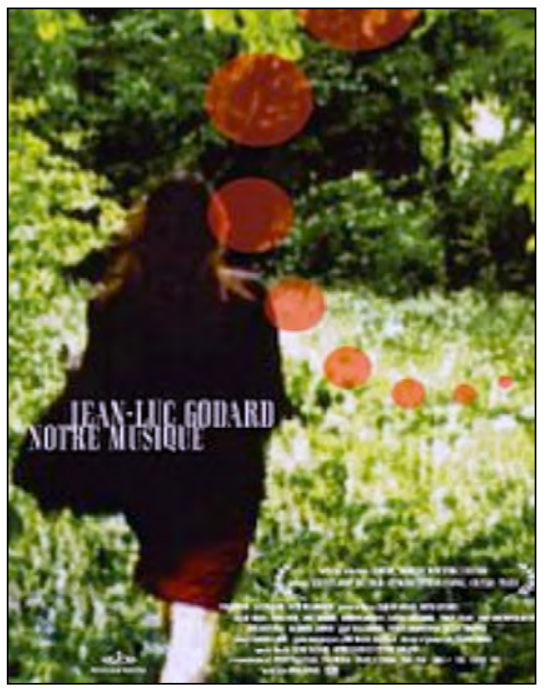

Nuestra música

Dir. Jan-Luc Godard (2004)

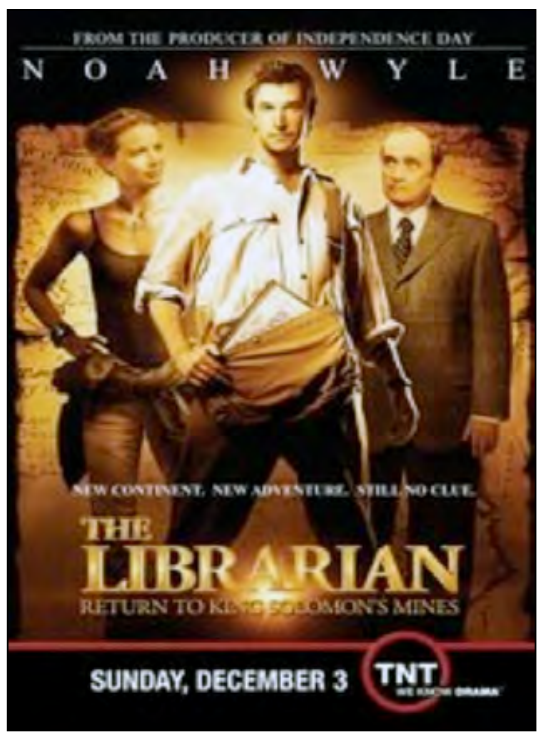

El bibliotecario 2: El mapa del rey Salomón Dir. Jonathan Fraker (2006)

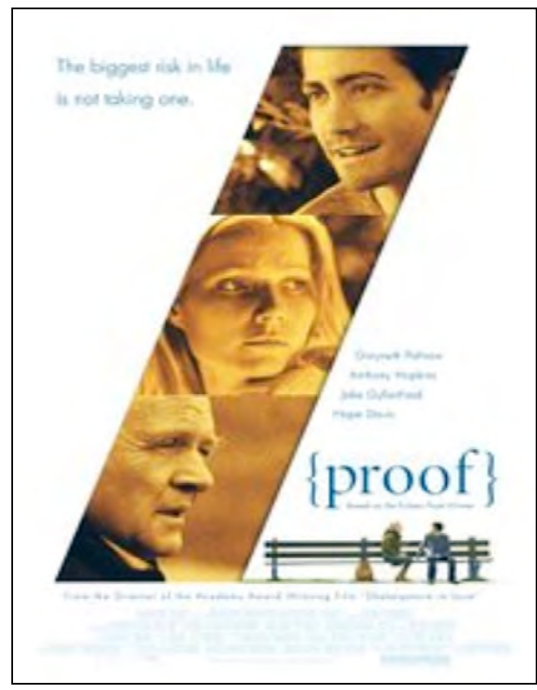

La verdad oculta

Dir. John Madden (2005)

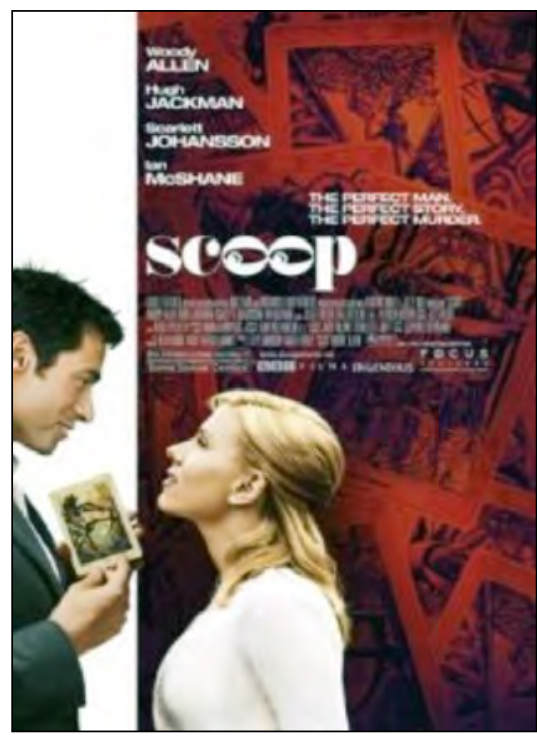

Scoop (Amor y muerte) Dir. Woody Allen (2006) 


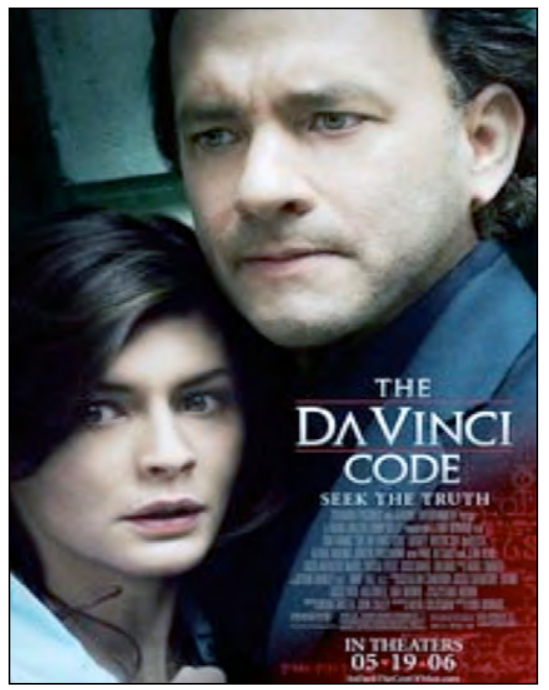

El código Da Vinci

Dir. Ron Howard (2006)

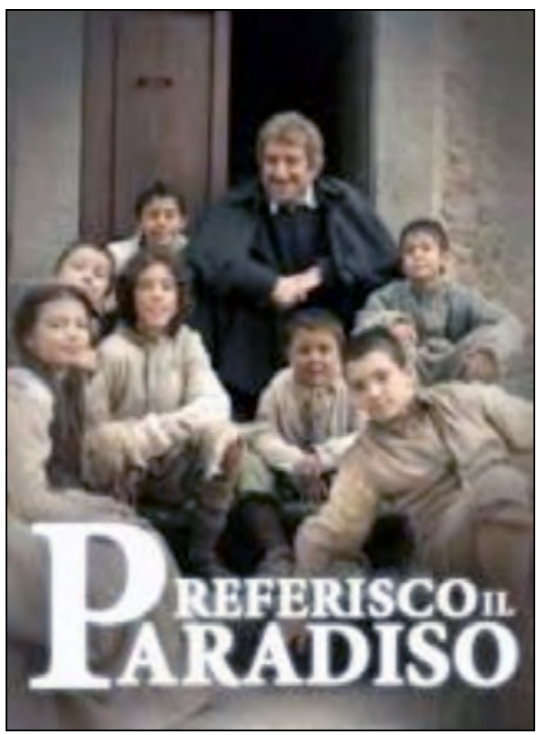

Prefiero el Paraíso

Dir. Giacomo Campiotti (2010)

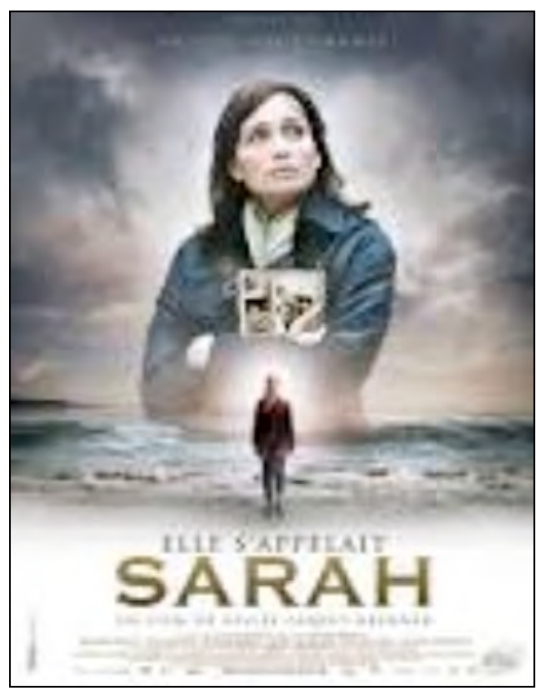

La llave de Sarah

Dir. Gilles Paquet-Brenner (2010)

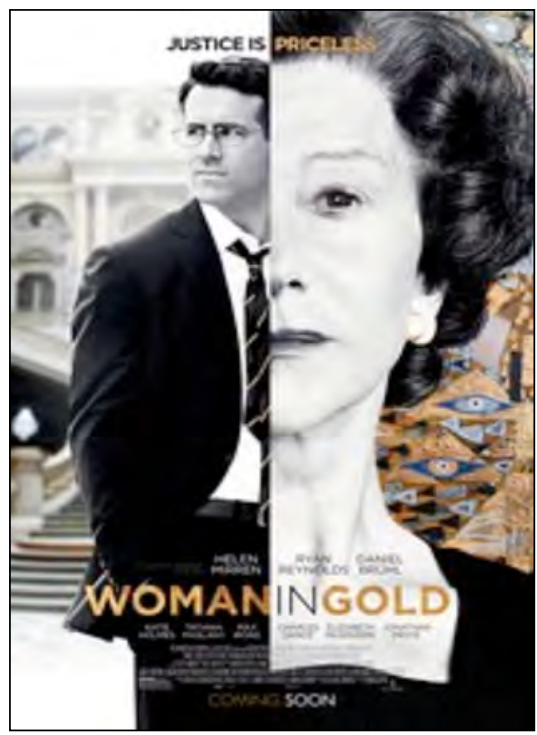

La dama de oro

Dir. Simon Curtis (2015) 
La ética de los sujetos emisores (autor del documento y profesional de la información documental)

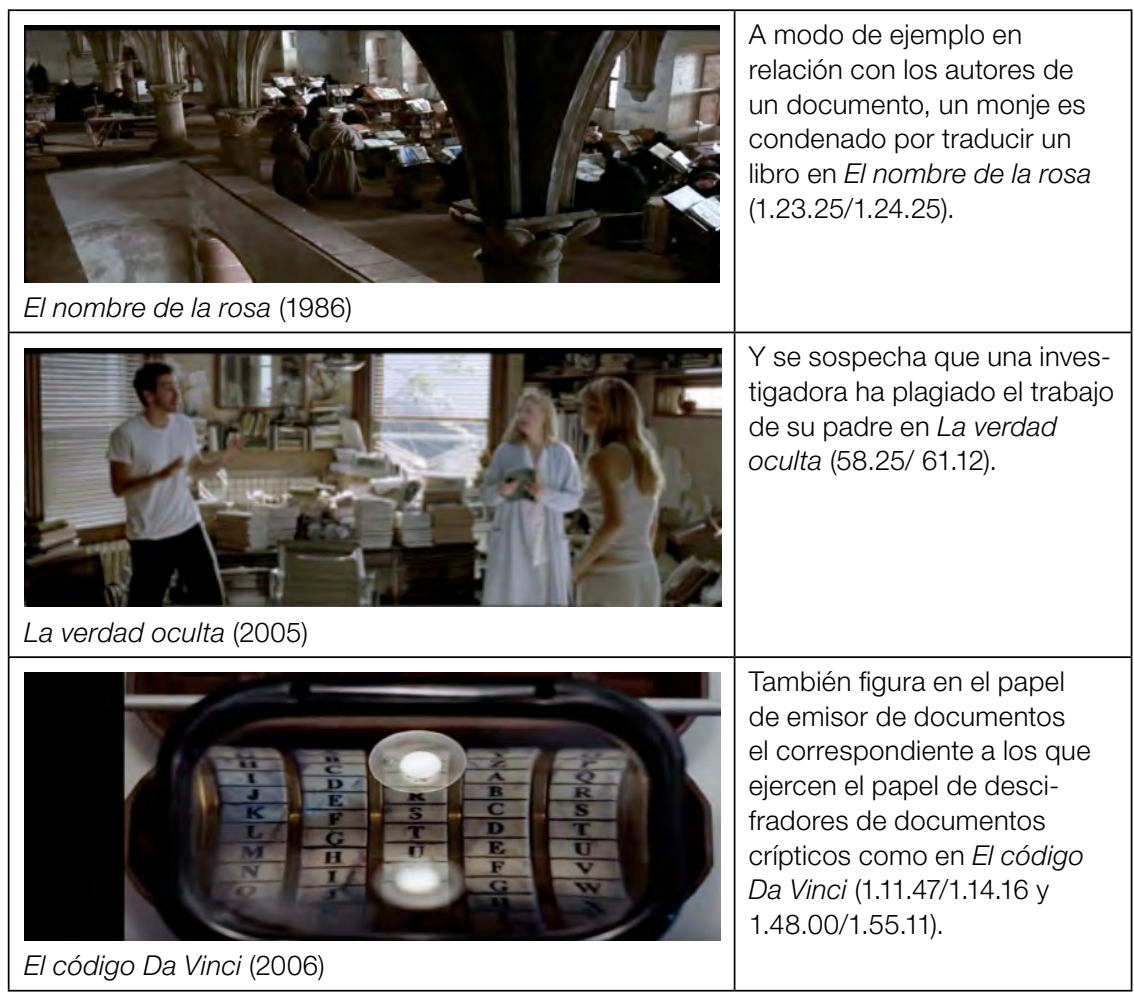

En cuanto a los profesionales de la información documental, sus representantes habituales, los bibliotecarios y archiveros, se han confirmado a lo largo de la historia como arquetipos característicos: el reparto de géneros (archivero y bibliotecaria), ratones de biblioteca, bibliotecarias feas y antipáticas hasta los tiempos más modernos en que dichos arquetipos han ido cambiando a mejor.

Hay ejemplos de todo ello: 


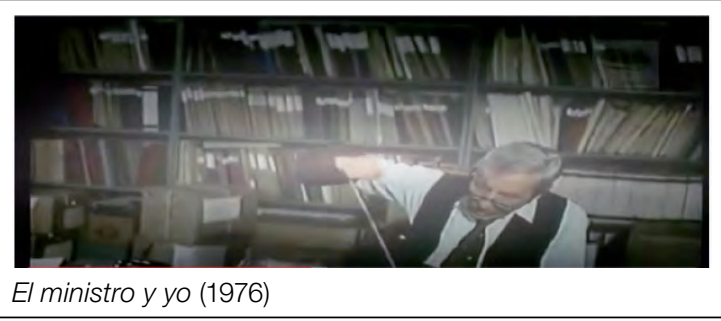

El funcionario archivero al que mandan al sótano donde sestean los expedientes como en El ministro y yo (43.27/47.12).

\section{Bibliotecarias}

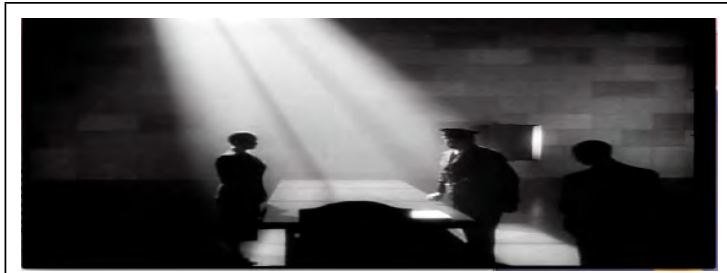

He aquí a la bibliotecaria restrictiva que solo permite la lectura de una parte de un determinado manuscrito en Ciudadano Kane (16.40/18.00).

\section{Ciudadano Kane (1941)}

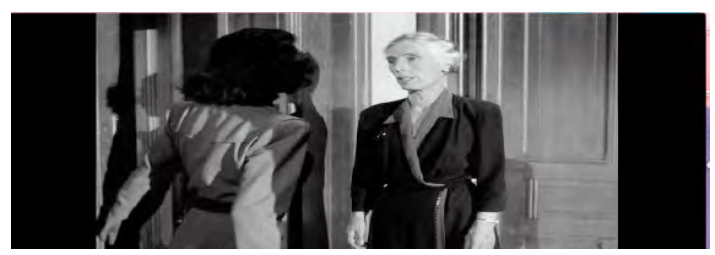

La bibliotecaria desagradable y gruñona o antipática y fea en La sombra de una duda (56.40/57.24).

La sombra de una duda (1943)

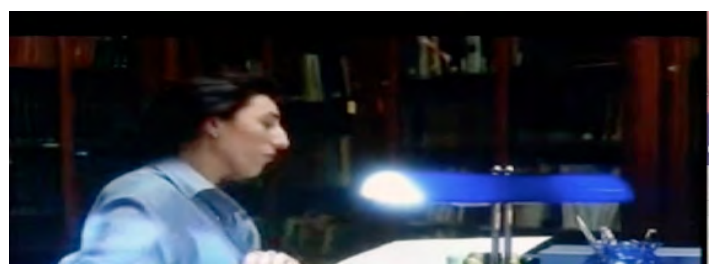

La bibliotecaria que cambia de comportamiento en su relación amorosa en El porqué de las cosas, una de las escasas películas españolas de tema bibliotecario. 


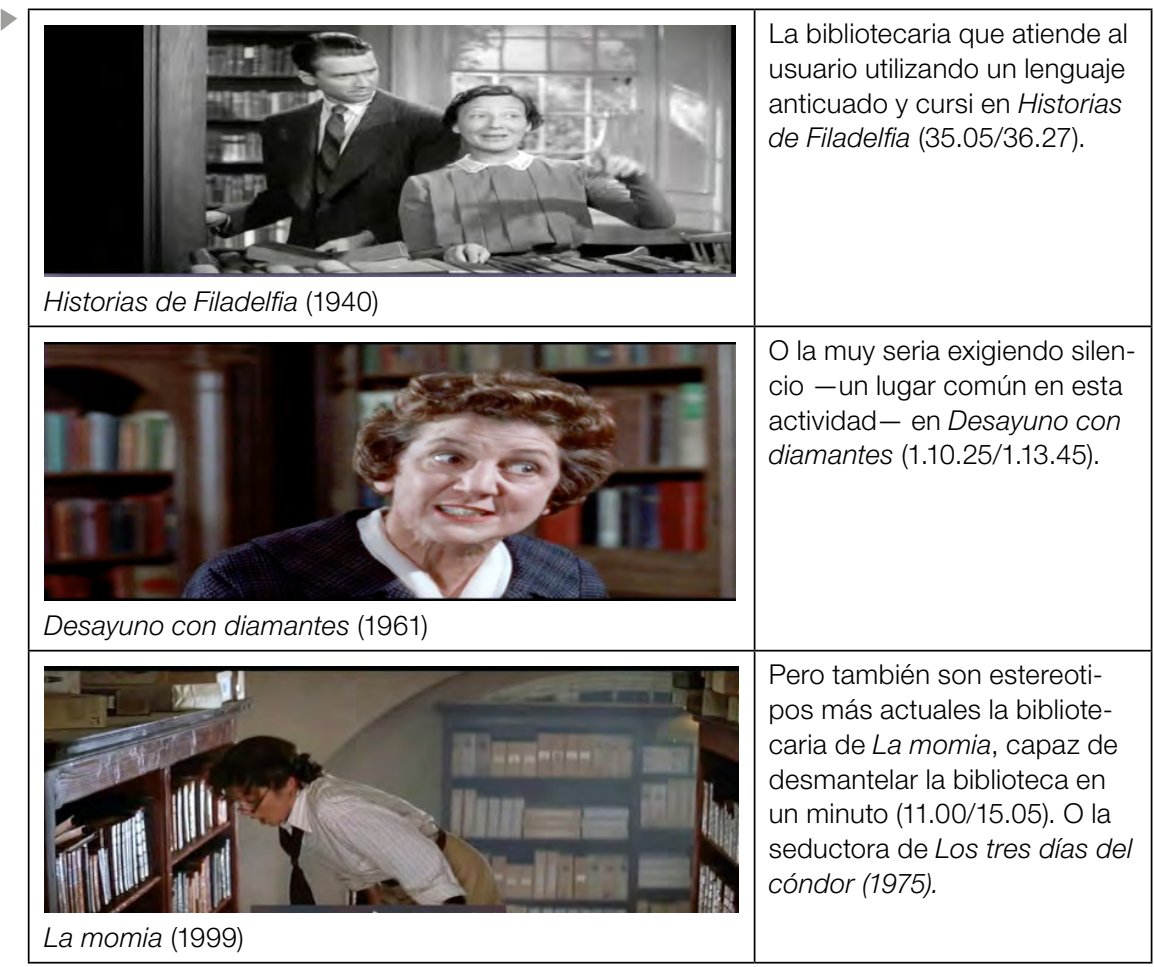

\section{Bibliotecarios}

Son menos los bibliotecarios en el cine pero con papeles más llamativos, acaso, que las bibliotecarias.

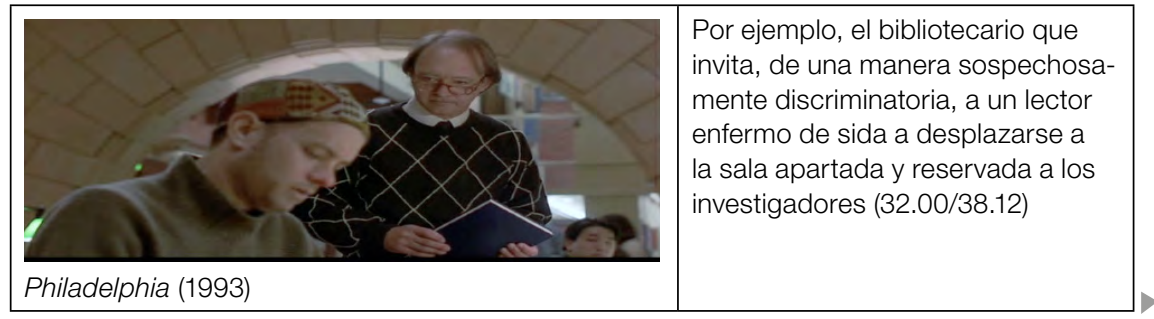




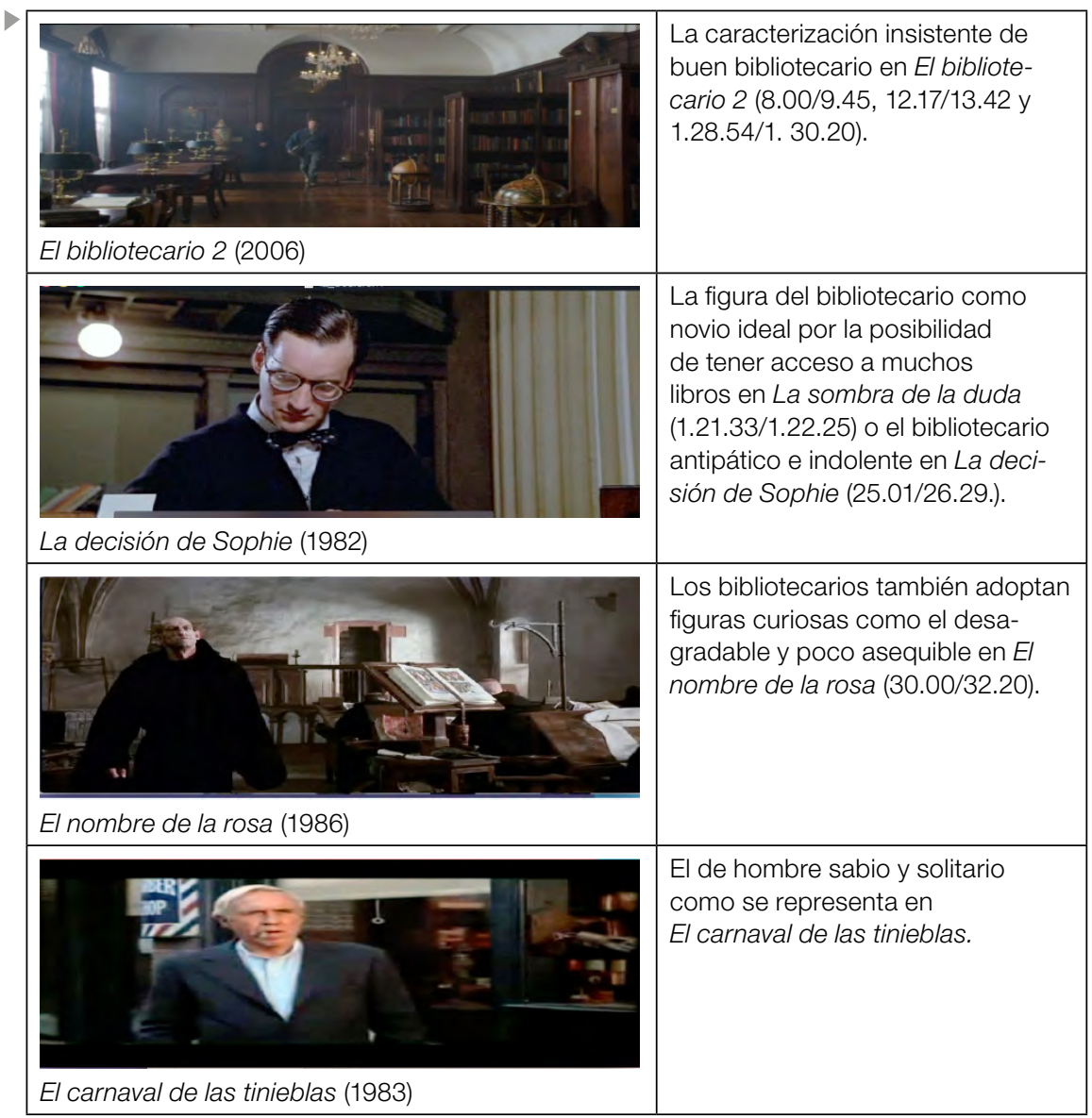

Sin embargo, los estereotipos citados van evolucionando a merced de la importancia cada vez más creciente de la función informativa y la respuesta a las demandas informativas puntuales de los usuarios, una cuestión que se refleja principalmente en el mundo empresarial.

En Su otra esposa, las empleadas del Departamento de Referencias (en el doblaje español se define como Investigación y Consultas) de una gran empresa privada norteamericana actúan más bien como documentalistas que trabajan en una pequeña biblioteca y 
realizan consultas puntuales (04.10/05.09 y 14.10/14.40), aunque también se muestran preocupadas por la posible pérdida de empleo ante la amenaza de instalación de un sorprendente ordenador electrónico (57.29/58.24).

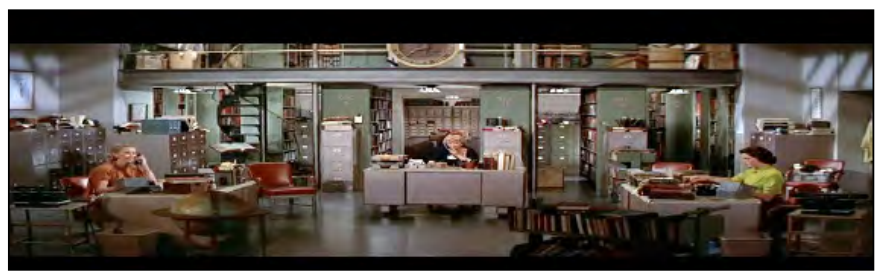

Su otra esposa (1957)

Otra película donde se refleja la demanda previa y urgente de información con objeto de obtener una cuenta publicitaria por dos agencias competidoras es Pijama para dos (4.00/5.24).

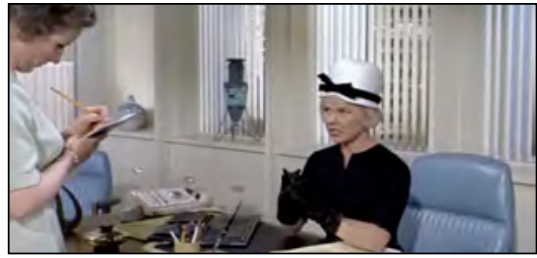

Pijama para dos (1961)

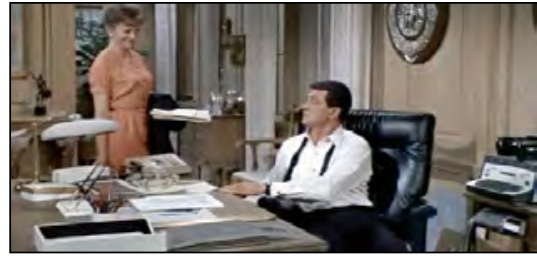

Pijama para dos (1961)

\section{Comportamientos éticos}

Sin embargo, el tema que debe ocupar más nuestra atención es el comportamiento ético positivo y negativo de los bibliotecarios y archiveros: 
La información documental...
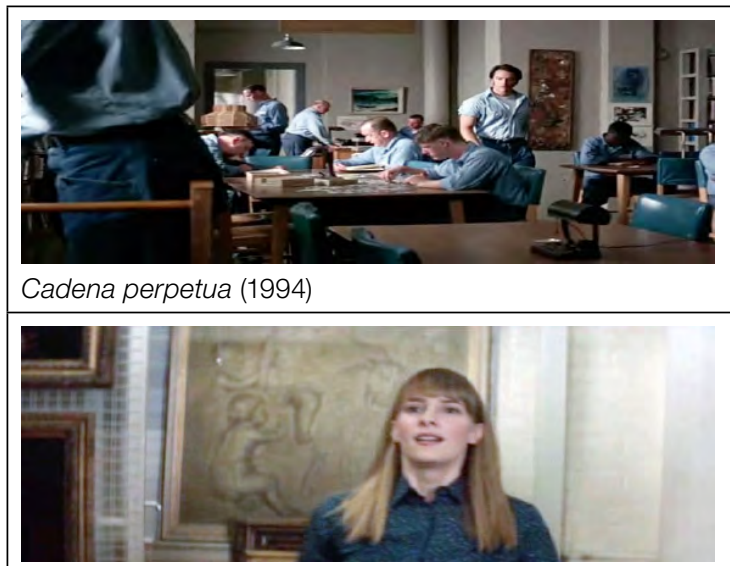

Como el ejemplo del presidiario tornado en bibliotecario de la cárcel como medio de redención y muy insistente en obtener recursos bibliográficos en Cadena perpetua (49. $31 / 59.40,1.02 .52 / 1.06 .40$ y 1.12.59/1.15.20).

En La dama de oro, la archivera se presta con riesgos a dejar de buscar documentos relativos a la restitución de un cuadro expropiado por los nazis a una familia judía (28.27/31.10 y $37.46 / 39.17)$.

La dama de oro (2015)

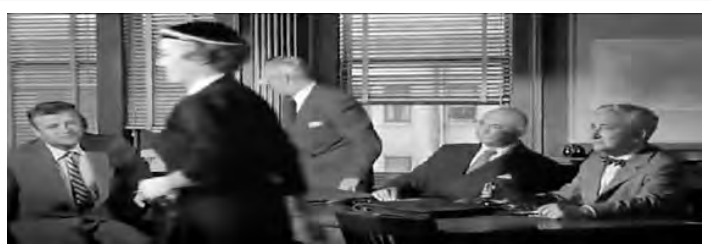

En El ojo del huracán, Storm Center, la bibliotecaria se niega a retirar un libro a pesar de la censura impuesta por el senador Mc Carthy.

En el ojo del huracán, Storm Center (1956)

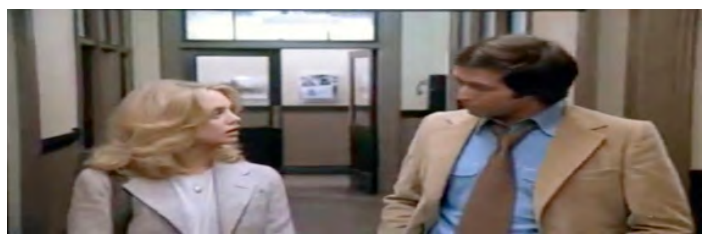

En otros casos, nuestros profesionales contribuyen a resolver crímenes como en Juego peligroso.

Juego peligroso (1978)

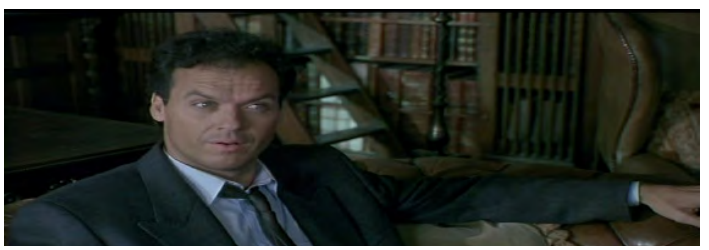

O en el caso de Batman, en que se consulta información en una biblioteca con un objetivo similar (46.38/47.50 y 52.28/53.10).

Batman (1989) 
En sentido contrario, el bibliotecario de El nombre de la rosa asesina a sus compañeros de monasterio al impregnar las hojas de los manuscritos con veneno (1.39.11/1.41.50).

Sin duda, el comportamiento más impactante en este apartado dedicado al buen o mal hacer de los profesionales del documento es el que advertimos en el filme Fabrenheit 451.

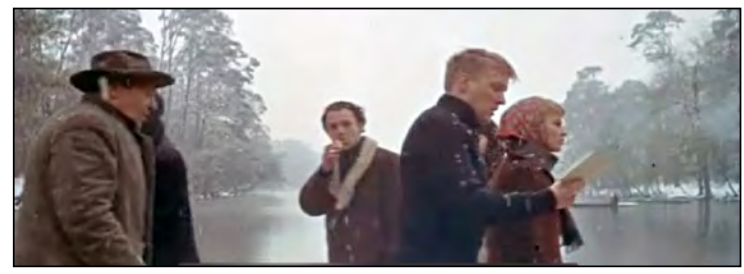

Fahrenheit 451 (1966)

En esta película, donde los lectores y sus libros son perseguidos hasta el exterminio, surge una nueva raza de seres humanos, los llamados hombres-libro que son, a la vez, lectores y profesionales de información, quienes la adecúan para su transmisión mediante el uso de la lectura y la memoria. Su identificación con los libros es tal, que el nombre de las personas es sustituido por el autor y título del libro, los cuales memorizan para la posteridad (1.25.00/1.27.00 y 1.40.16/1.47.29).

\section{LA ÉTICA DEL MENSAJE DOCUMENTARIO}

Como decíamos más arriba, los aspectos éticos relacionados con el mensaje documentario se vinculan a los aspectos de la conservación y preservación de los libros y documentos (memoria); a la censura, en general, y, en particular a la que comprende los libros prohibidos ocultos o secretos; a su destrucción mediante el fuego; a la mutilación; a la relación con la comisión de delitos y, desde un punto de vista positivo, a los intentos desinteresados de salvar libros. 
En nuestra opinión, los filmes que recogen mayormente las notas expuestas son Fabrenbeit 451 y El nombre de la rosa. El primero plantea un problema pavoroso: la persecución violenta de los poseedores de libros, quienes son considerados un mal para la sociedad; sin posibilidad de preservar la memoria de la Humanidad, ocasionan una fusión entre el ser humano y los libros o, dicho de otro modo, la encarnación de los libros concretos en personas concretas, quienes se convierten en el soporte de sus contenidos mediante la conservación de los mismos en la memoria. En el segundo filme, las notas más características son el crimen y la destrucción de libros. Otro de los aspectos en este artículo concierne a los libros secretos, ocultos y prohibidos por la censura.

\section{Libros secretos}

Un misterioso documento envasado y críptico necesita ser descifrado para guiar al hallazgo del Santo Grial. Su leyenda se muestra en El código Da Vinci (46.40/49.20).

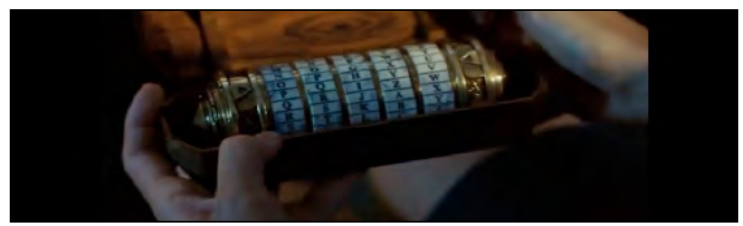

El código Da Vinci (2006)

Por otra parte, en Indiana Jones y la última cruzada, hay un manuscrito que también sirve para lograr el hallazgo del Santo Grial (17.30/17.40 y 19.35/26.23).

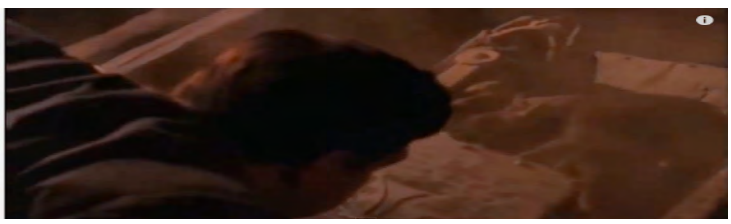

Indiana Jones y la última cruzada (1989) 


\section{Libros censurados}

En Ciudadano Kane, hay un manuscrito que refiere datos del ciudadano, del cual está autorizada una parte de la lectura (16.40/18.00).

La censura en general se observa en el citado Fabrenbeit 451 en el episodio en el que los bomberos, auténtica policía represora, registra a los ciudadanos en busca de libros ocultos (38.12/39.12).

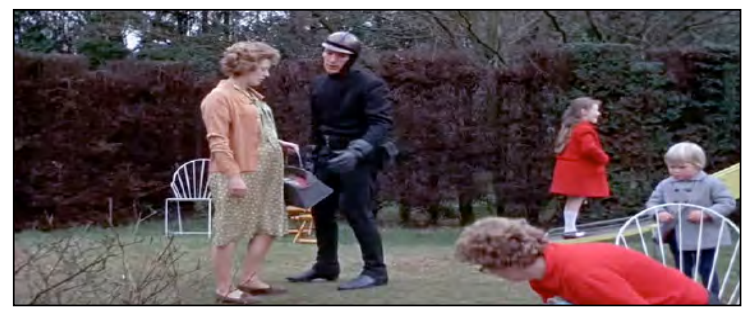

Fahrenheit 451 (1966)

En el filme se comenta la técnica para descubrir los libros que se ocultan en las casas de los particulares (20.34/22.54) y la existencia de los llamados hombres-libro, quienes son guardadores del saber y viven ocultos (1.25.00/1.27.00). En este contexto, no es de extrañar la definición y el significado de los libros que es expresada por el capitán de los bomberos quemadores de libros (1.28.41/1. 33. 38).

\section{Libros perdidos y escondidos}

Otros enfoques similares a éste se encuentran en $E l$ nombre de la rosa cuando el franciscano Baskerville indaga sobre la existencia de la perdida segunda parte de la Poética de Aristóteles (32.26/34.20), pregunta sobre el paradero de los libros de la biblioteca (34.21/36.04), constata que hay libros escondidos (38.00/41.05) y que el acceso a la biblioteca donde tal vez se encuentran es imposible (53.00/54.55). 


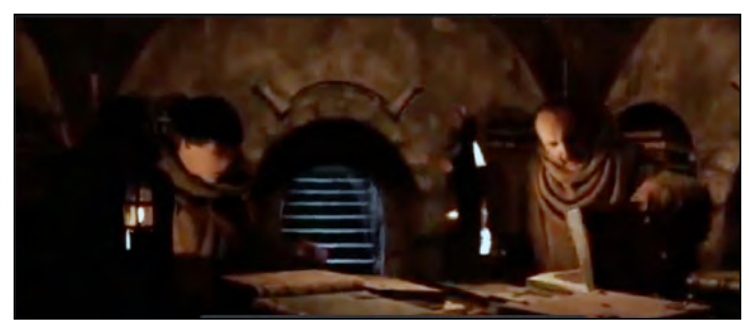

El nombre de la rosa (1986)

El hallazgo de un verdadero tesoro bibliográfico - un libro del rey Salomón- se expone en El bibliotecario 2 (1.08.10/1.10.42).

El tema de los libros perdidos, sugerentes y que son motor de la imaginación aparece en El guardián de las palabras (17.41/19.51).

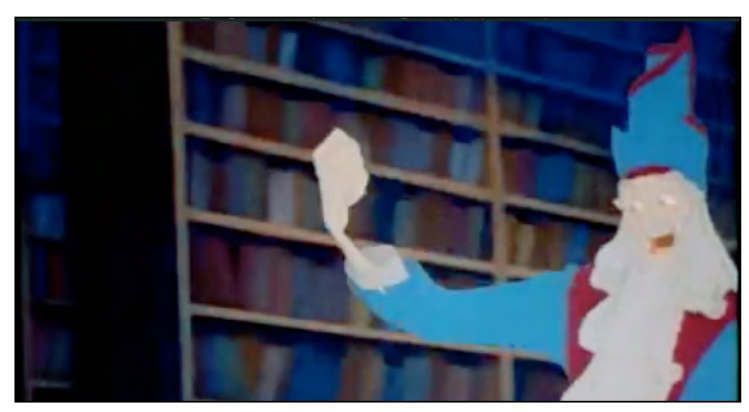

El guardián de las palabras (1994)

Libros mutilados o estropeados

En El cielo se equivocó, el protagonista, ante la actitud antipática de la bibliotecaria, simula que las hojas de un manuscrito han sido estropeadas. 
Uso ético de la información:...

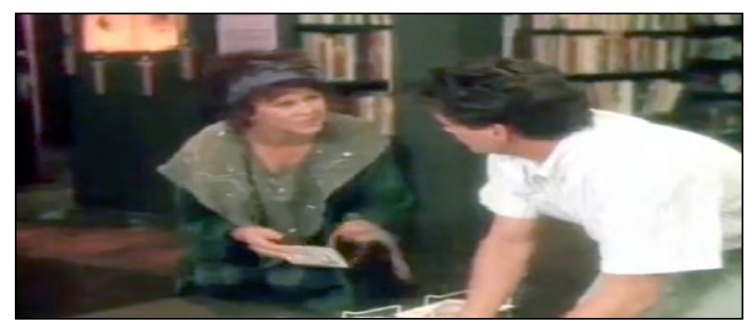

El cielo se equivocó (1989)

Asimismo, observamos la mutilación de libros en los filmes Ábrete de orejas y El carnaval de las tinieblas.

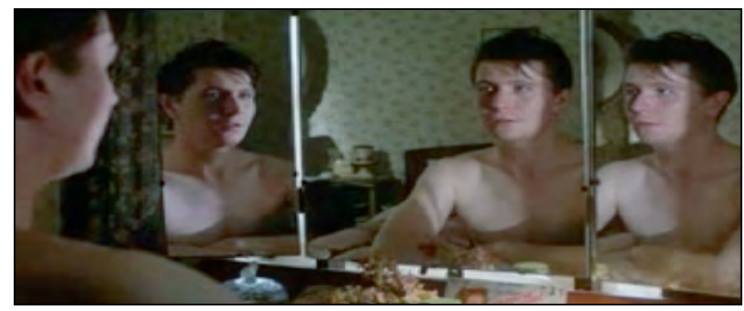

Ábrete de orejas (1987)

Libros quemados

Pero más allá de la mutilación, el fuego cobra un papel protagonista en la destrucción de libros. Por razones ideológicas, en la posguerra civil española fueron quemados libros "antiespañoles". Esto se muestra en El año de las luces (39.10/40.25).

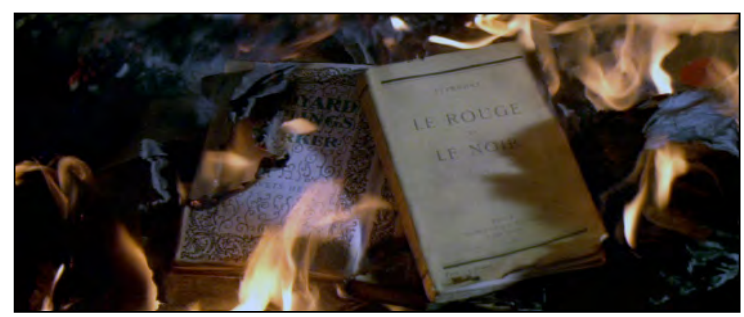

El año de las luces (1986) 
También hay quemas de libros en El nombre de la rosa (1.45.50/1.52.14 1.53.07/1.53.59), en el conocido pasaje de la quema de libros de caballerías en $E l$ Quijote de Cervantes, en $E l$ día de mañana después (2004) y en el filme Prefiero el paraíso (1.17.50/1.19.40).

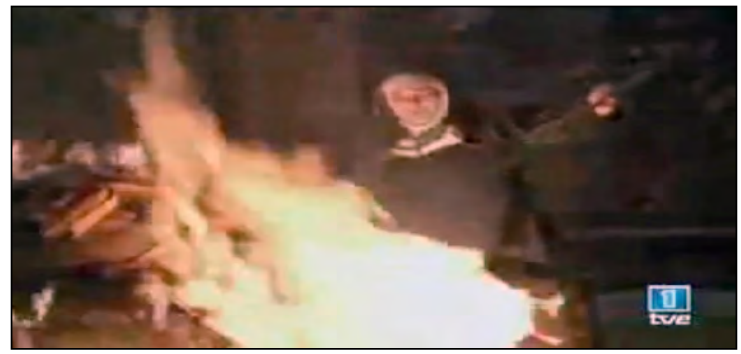

El Quijote de Cervantes (1991-1992)

Sin embargo, los ejemplos más pavorosos de ello los encontramos en Fabrenbeit 451, cuando los bomberos se aprestan en expedición hacia la quema de libros ocultos en la casa de un ciudadano y convierten la hoguera en auténtico ritual (1.05/6.16); se pregunta al bombero protagonista "por qué quemar libros" (11.02/12.24) y la televisión facilita los datos acerca del volumen de libros quemados cada día (14.51/15.20).

\section{Libros incitadores del crimen}

Por culpa de un libro perdido, se producen crímenes en El nombre de la rosa (1. 39.11/1.41.50), algunos de ellos provocados por la inhalación de las hojas envenenadas de un libro (1.45.50/1.52.14). Sin embargo, debemos destacar el noble afán del protagonista Guillermo de Baskerville por descifrar y salvar los libros en el incendio de la biblioteca del monasterio (1.15.00/1.16.29 y 1.55.58/1.58.42). Además, se cometen más crímenes en ocasiones al tener que demostrar la autenticidad de un libro por medio de la comparación con otros dos ejemplares presuntamente falsos. 
En La novena puerta, la búsqueda de los ejemplares del libro Las nueve puertas del reino de las sombras (12.10/17.10) está vinculada al culto al diablo desarrollado por una cofradía mediante rituales (36.10/36/51). Los propietarios de dos ejemplares restantes son ejecutados (56.10/1.00. 31 y 1.23.00/1.25.50).

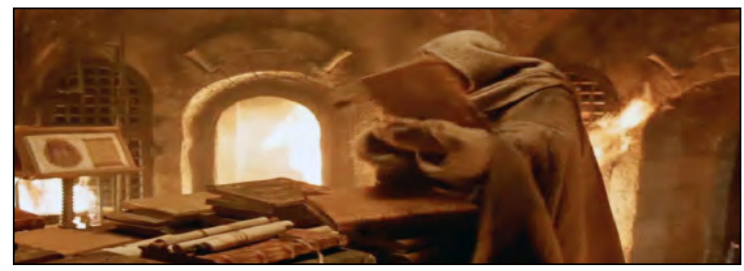

El nombre de la rosa (1986)

\section{La ética del medio}

Los archivos, las bibliotecas y los museos como recintos donde los datos se transforman en información, cobran vida en numerosos filmes donde se presenta la evolución de estas instituciones, que son mostradas como los tradicionales estereotipos o como las modernas unidades de información marcadas por el desarrollo de las nuevas tecnologías que cobran visión de futuro en filmes de ciencia ficción.

El archivo lleno de papeles y en el lugar menos importante de la entidad que lo alberga se observa de modo humorístico en $E l$ ministro y yo (42.12/45.10).

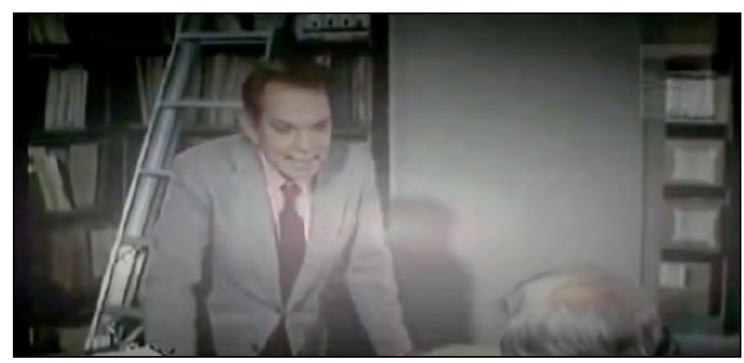

El ministro y yo (1976) 


\section{Biblioteca tradicional}

\section{La biblioteca tradicional estereotipada se muestra en el diálogo "Te sorprendería lo que aprendes en la biblioteca" en El biblioteca- rio 2 (1.20.50/1.21.28).}

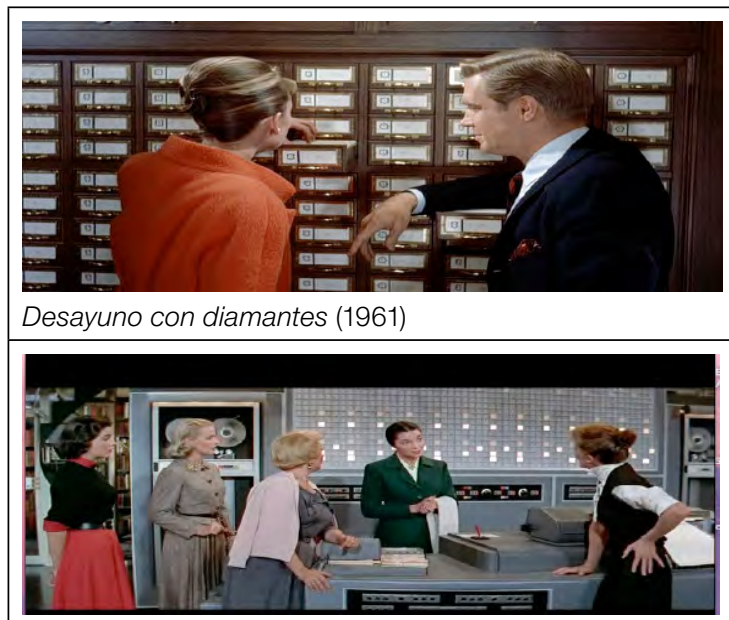

Su otra esposa (1957)

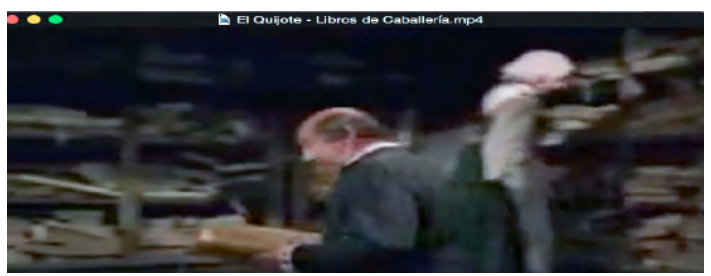

El Quijote de Cervantes (1991-1992)
La biblioteca tradicional de acuerdo con las antiguas técnicas convencionales de catalogación y clasificación se advierten en Desayuno con diamantes (1-10.25/1.13.45)

Podemos ver el choque de la biblioteca tradicional con la emergente que ya se vislumbra en la década de los cincuenta en Su otra esposa con la irrupción de un gran ordenador que trata de responder a todas las preguntas planteadas por los usuarios $(35.00 / 36.10$ y 37. 37/38.15).

La biblioteca permanentemente silenciosa se observa en Desayuno con diamantes y Cartas a Iris o como un espacio sagrado en Cielo sobre Berlín; polvorienta en La máquina del tiempo; lugar mágico en El guardián de las palabras (The Pagemaster) y como un lugar aburrido en El bibliotecario 2 (16.10/16.54).

La biblioteca privada de un lector loco por sus libros la vislumbramos en El Quijote de Cervantes. 
Bibliotecas en películas de ciencia-ficción

En cuanto a los filmes de ciencia ficción, la biblioteca adquiere nuevas formas: aparece como un gran ordenador desprovisto de libros y, por tanto, de acciones lectoras, en 2001.Una odisea del espacio.

En Inteligencia artificial, la biblioteca aparece como un lugar de reunión al principio de la película (1.00/6.50).

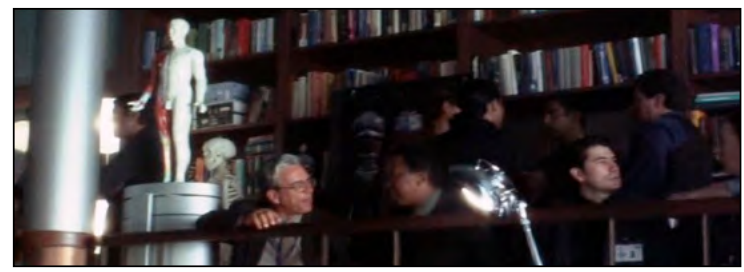

Inteligencia artificial (2001)

\section{Aspectos éticos}

Los aspectos éticos a los que nos referimos a continuación pueden ser positivos, en los que se manifiesta el papel coadyuvador del archivo y la biblioteca a favor de los seres humanos o en su contra. En el primer apartado, un archivo facilita importante documentación para la resolución de un pleito encaminado a la restitución de un cuadro expropiado a una familia judía por el régimen nazi austriaco en La dama de oro. En cuanto a la biblioteca, ésta aparece como dinamizadora en Cadena perpetua, una biblioteca de prisión (49. 31/59.40) 


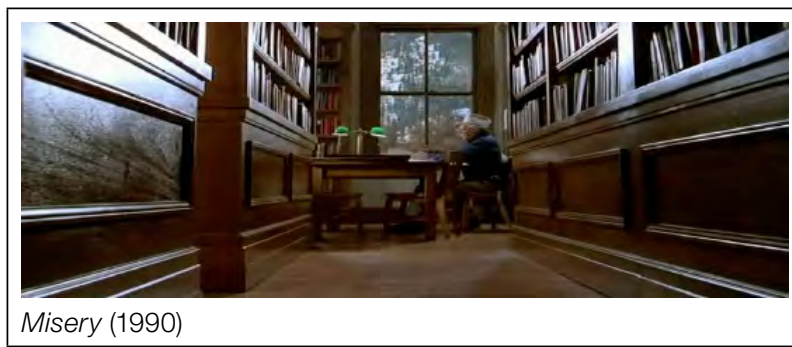

Promoviendo la lectura como un instrumento al servicio del esclarecimiento de crímenes en Misery (1.21.00/1.22.20).

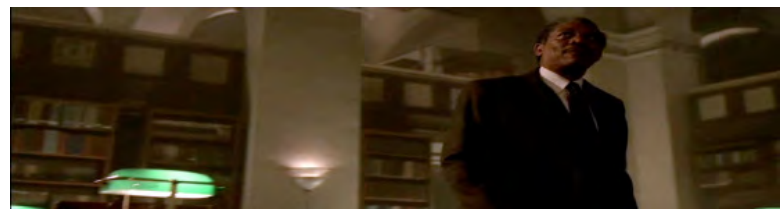

En Seven (24.29/28.00). Seven (1995)

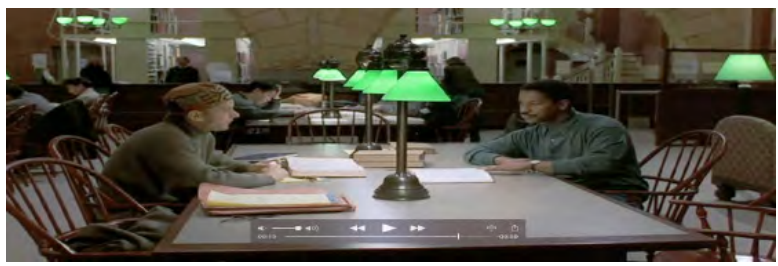

La biblioteca es una fuente para el conocimiento de la discriminación social hacia los enfermos de sida en Philadelphia (32.00/38.12).

Philadelphia (1993)

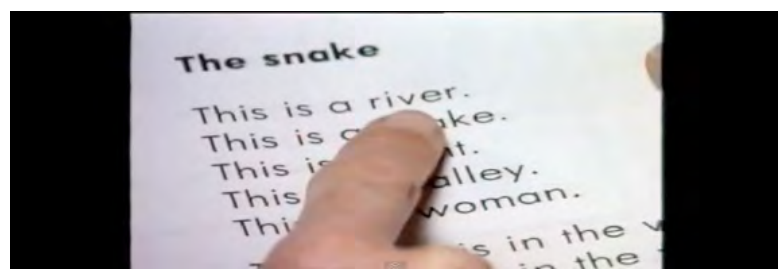

También es un medio de formación para la enseñanza de la lectura o ayuda a estudiantes en Cadena perpetua (1.22.00/1.25.40) y en Cartas a Iris.

Cartas a Iris (1990)

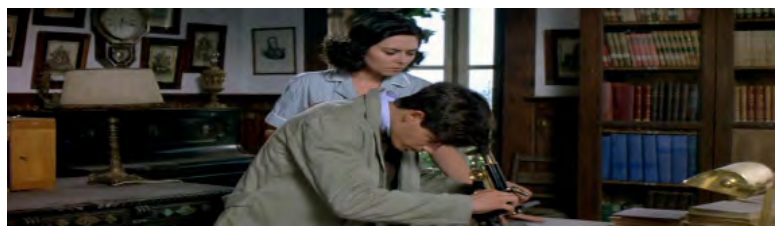

En El año de las luces, una biblioteca es a la vez laboratorio y museo (35.19/38.40 y $55.02 / 56.40)$.

El año de las luces (1986) 
Uso ético de la información:...

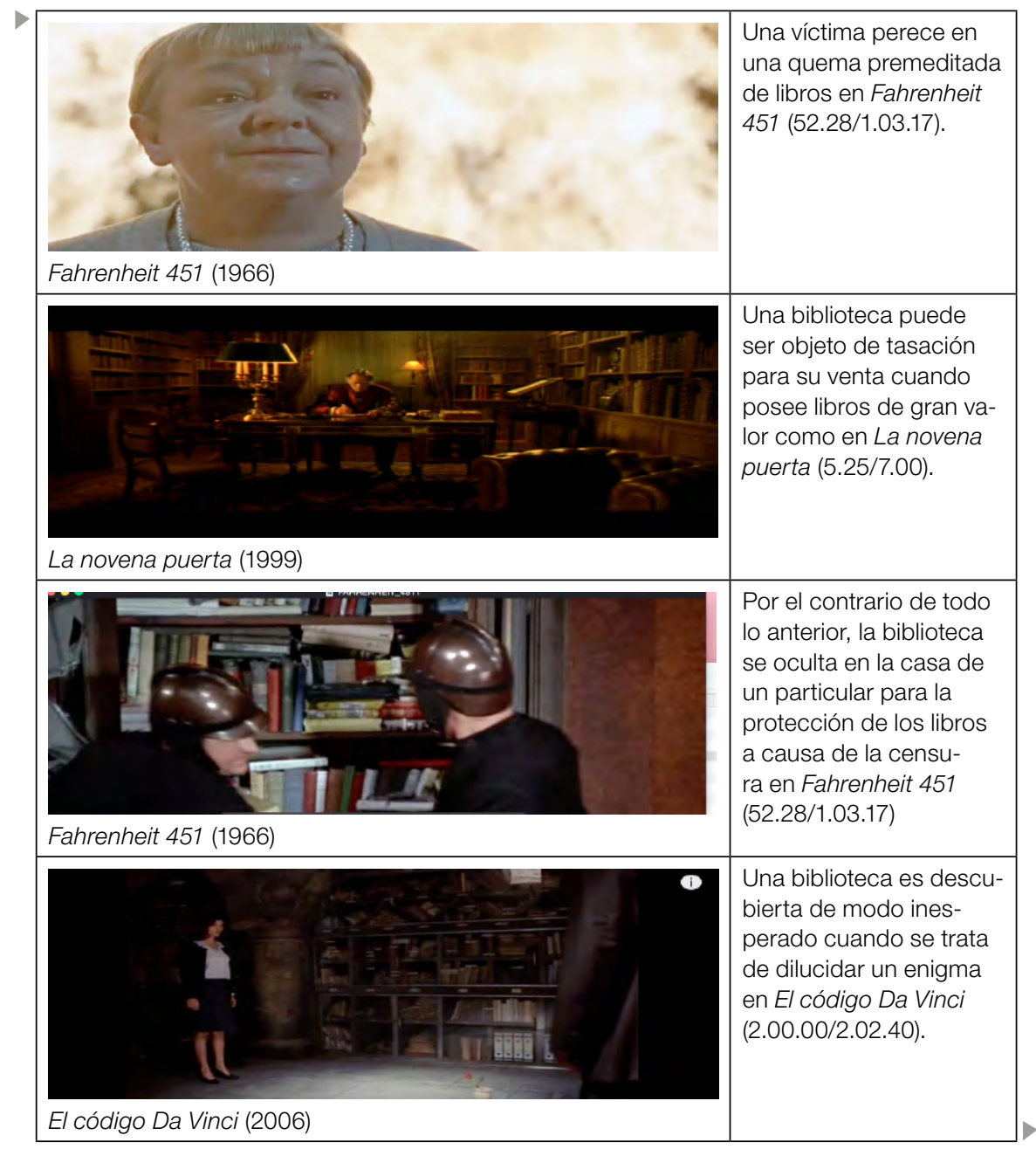




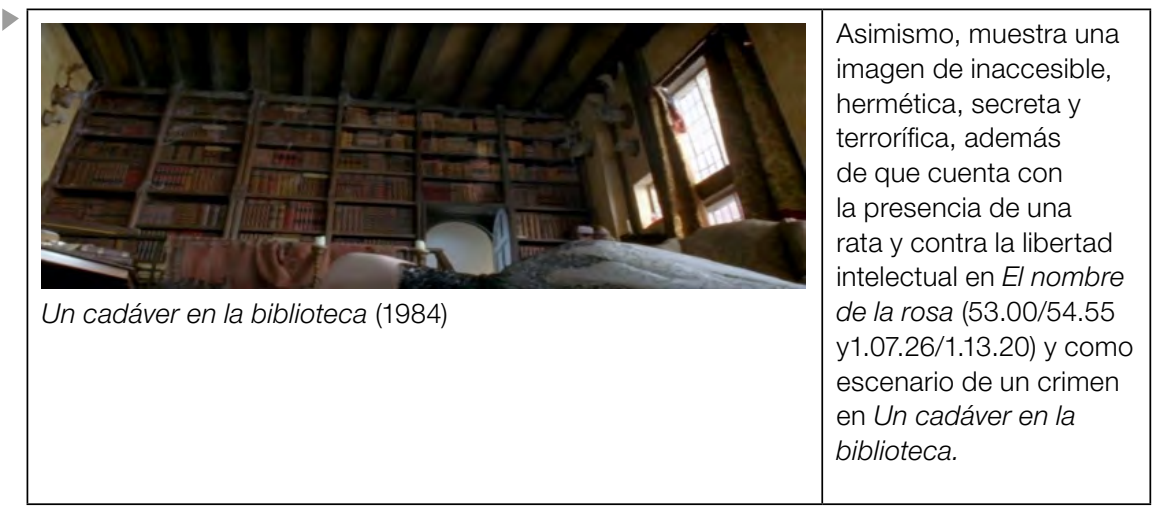

\section{LA ÉTICA DEL SUJETO RECEPTOR (USUARIO, LECTOR, INVESTIGADOR)}

Bajo la denominación de sujeto receptor del proceso informativodocumental, incluimos al usuario en general y, en particular, a los lectores y buscadores o investigadores de datos en las fuentes documentales; específicamente, los profesionales del periodismo. En el ámbito de la ética del sujeto receptor, los lectores desempeñan o han desempeñado diversos papeles.

\section{Lectores/usuarios}

Un típico, tradicional y joven lector aparece en El año de las luces (22.42/25.52).

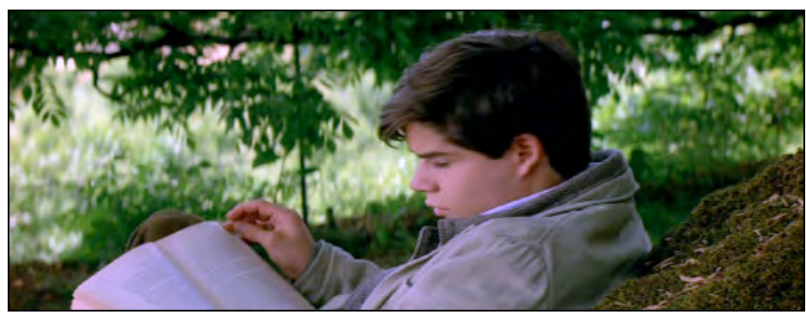

El año de las luces (1986) 
En Su otra esposa, presenciamos la inhóspita experiencia de un usuario que recibe la información puntual por medio de un innovador ordenador electrónico, incluidos errores en sus respuestas (1.20.00/1.23.01 y 1.26.49/1.29.16).

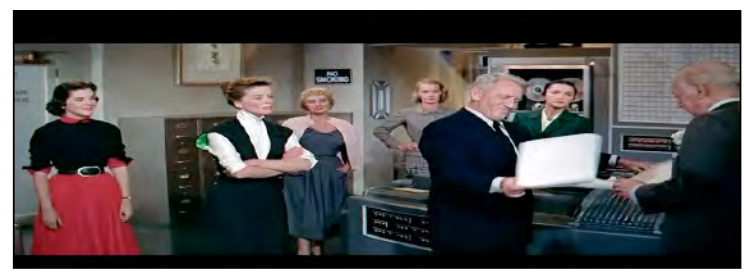

Su otra esposa (1957)

\section{Censura}

En Fabrenheit 451, observamos las denuncias que experimentan personas por el hecho de cultivar la lectura secretamente (43.10/44.10 y 1.20.58/1.21. 34), y a las personas detenidas (14.51/15.20) y conducidas a la muerte en compañía de los libros que guardaban celosamente (52.28/1.03.17). Al parecer, merece la pena el riesgo por el deleite de la lectura como vemos en el caso del protagonista del filme, que lee despacio y en voz alta escondido en su casa (35. 30/38.01).

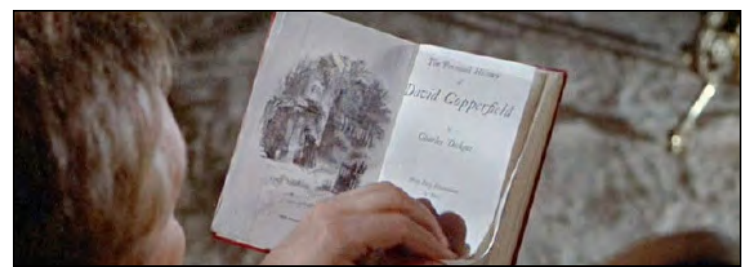

Fahrenheit 451 (1966)

El sentimiento de la lectura se había manifestado previamente cuando alguien con anterioridad le había preguntado "LLee libros? ¿Es usted feliz?” (12.40/13.08). Cuando su esposa descubre los libros ocultos, él manifiesta que los libros son su familia y que le dan cultura (49.20/51.46). Cuando afirma categóricamente "Tengo que 
leer", logra la emoción de las amigas de su esposa al leer un fragmento de un libro (1. 03.57/1.10.94). Por lo demás, la emoción de la lectura llevada a la locura se manifiesta en El Quijote de Cervantes (cap. 6, 0.00/5.11).

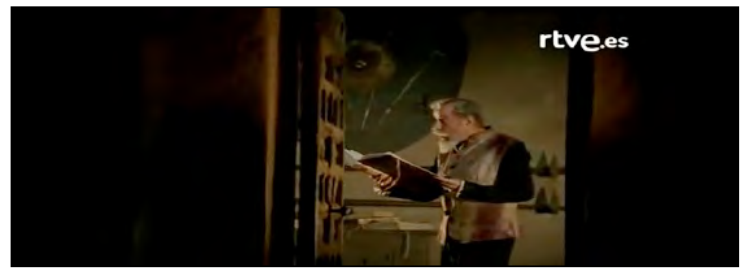

El Quijote de Cervantes (1991-1992)

\section{Lectores envenenados}

En El nombre de la rosa, el monje herbolario muere envenenado a causa de un libro oculto (1.27.58/1.30.12).

\section{Hombres-libro}

En Fabrenheit 451, la necesidad de conservar la cultura y el saber que prestan los libros conduce a la creación de los hombres-libro que viven ocultos por miedo (1.25.00/1.27.00) y que han cambiado su verdadero nombre por el de los títulos de los libros que aprenden de memoria para asegurar su preservación y transmisión a las generaciones venideras (1.40.16/1.47.29).

Investigadores de datos

El otro grupo de usuarios que merecen nuestra atención en el presente apartado lo constituyen investigadores de datos y periodistas que son requeridos para aclarar presuntos asesinatos o asuntos de carácter sociopolítico.

El filme La novena puerta presenta a un marchante de libros antiguos al que se le encarga demostrar la autenticidad de un libro frente a otros dos aparentemente iguales (18.00/20.46). Para ello, se 
documenta en una biblioteca (21. 35/23. 30). Su vida corre peligro en varias ocasiones (1.19.00/1.21.46). Alguien trata de destruir los dos ejemplares objeto de búsqueda. A lo largo del film, se detecta una gran obsesión por el libro por parte de la secta que lo adora a través de un ritual satánico (1.43.20/1.44.20) y de la muerte del bibliófilo admirador de Lucifer a quien se atribuye la autoría del libro en cuestión (1.5300/1.54. 36).

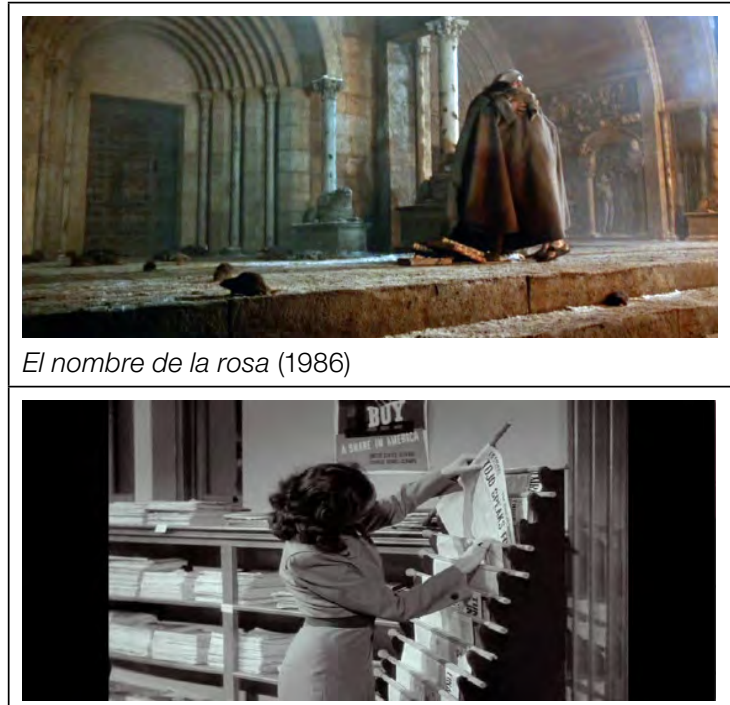

En El nombre de la rosa, el franciscano Guillermo de Baskerville salva in extremis los libros de la biblioteca en medio del incendio que la destruye (1.55.58/1.58.42).

La sombra de una duda (1943)

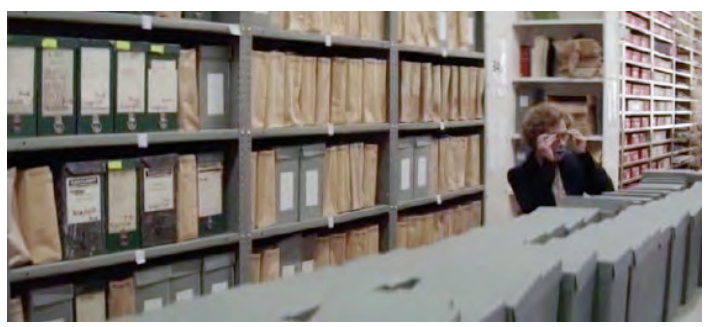

Las investigaciones en bibliotecas permiten vislumbrar pistas para la resolución de sendos delitos en Misery (1.21.00/1.22.20), en Seven (24.29/28.00) y en La sombra de una duda (54.27/58.59).

La dama de oro (2015)

En La dama de oro, el abogado y la protagonista indagan en la búsqueda de los documentos que les permitan recuperar un cuadro expropiado a la familia judía por el régimen nazi de Austria en un museo (28.27/31.10) y en un archivo al que acuden con la actitud del detective que busca pruebas (37.47/39.17). 


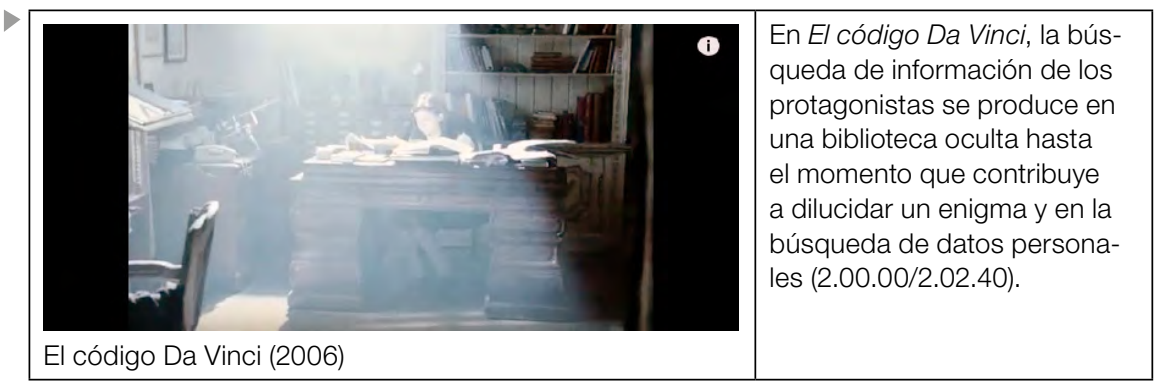

\section{Periodistas}

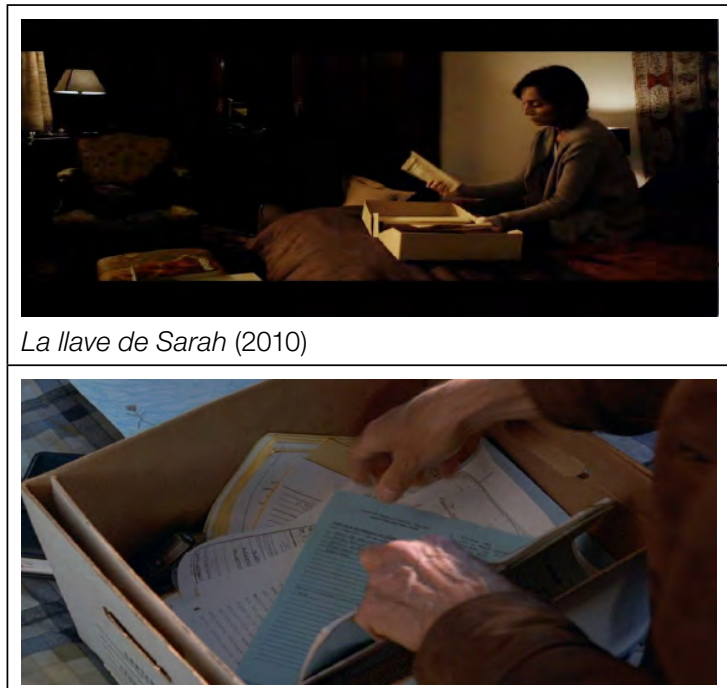

Ejecución inminente (1999)

En La llave de Sarah, la periodista examina los documentos y encuentra al hijo de Sarah que le muestra sus diarios (1.06.16/1.09. 36 y 1. 34.40/1.38.54).

En Ejecución inminente, el periodista investiga en una base de datos acerca del posible testigo de un crimen. Más adelante, en casa de la periodista que llevaba el reportaje sobre el caso, encuentra datos sobre el nombre y domicilio del otro testigo (el que resultó ser el asesino) (1.27.15/1.30.50). En la visita a la abuela del mismo, conoce que éste ha muerto pero se fija en un medallón que la abuela lleva colgado al cuello, detalle que llegará a ser decisivo para lograr la libertad del condenado. 


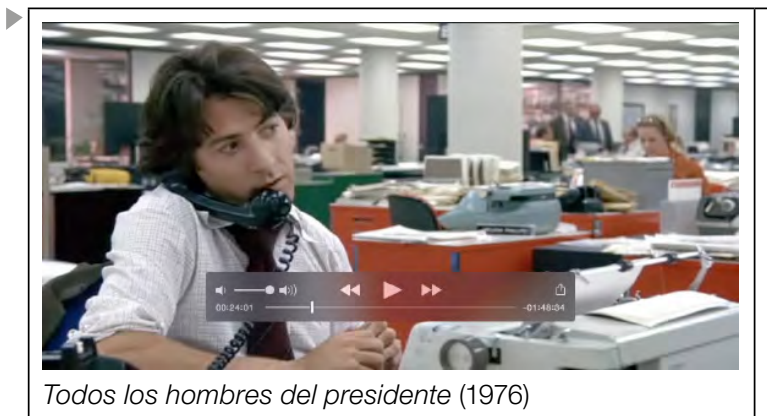

En Todos los hombres del presidente, los periodistas acuden a la Biblioteca del Congreso de los Estados Unidos y analizan diversas fuentes de información (23.50/29.57 y $42.38 / 52.04)$.

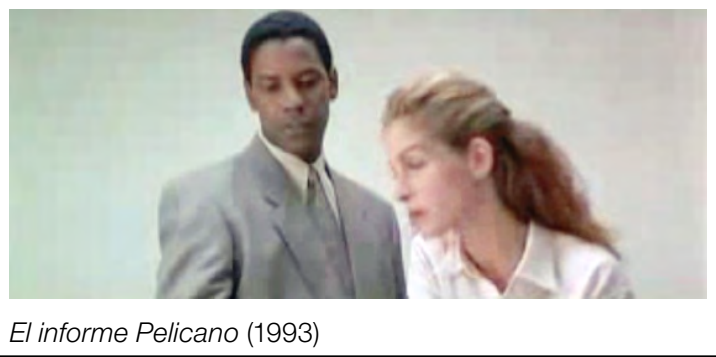

En El informe Pelicano, tras entrevistar a la esposa del asesinado, los protagonistas encuentran los documentos de prueba en una caja de seguridad y, tras ello, sufren acoso y peligro de muerte (30.40/41.00).

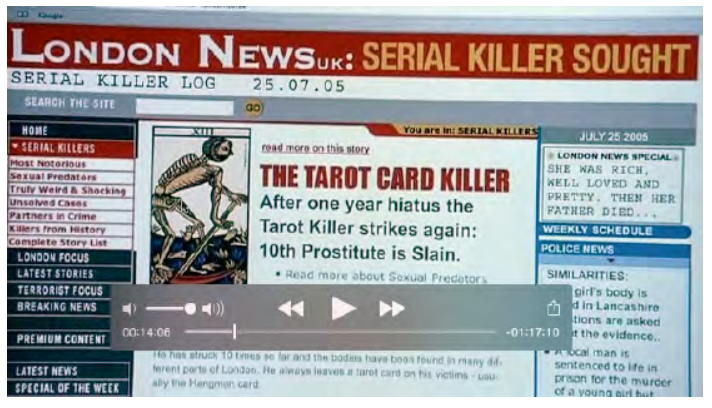
Scoop (2006)

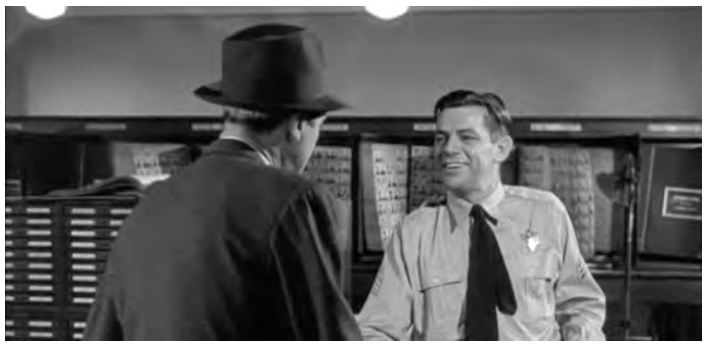

En Yo creo en ti, el periodista, cada vez más identificado con su papel de detective, realiza diversas tareas de búsqueda de fuentes documentales y consulta de archivos de la policía $(09.14 / 10.47$ y 51.41/1.04.15). 


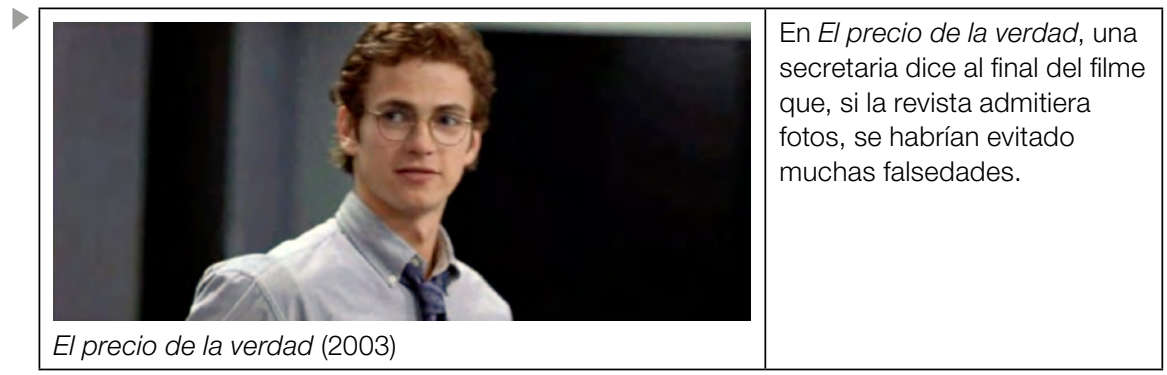

\section{REFERENCIAS BIBLIOGRÁFICAS}

Bustamante Rodríguez, Antonio Tomás (2007). "Ética, bibliotecas y bibliotecarios: deontológica para la profesión bibliotecaria”. Educación y Biblioteca, 159, pp. 117-129.

Gracia Armendáriz, Juan (1995). "Reflexiones en torno a la representación y uso de la biblioteconomía y la documentación en la novela y en el cine". Documentación de las Ciencias de la Información 17, pp. 85-102.

Laudano, Claudia Nora; María Cecilia Corda, Javier Planas y Pamela Pelitti (2012). "Imaginarios futuros sobre el libro y las bibliotecas en el cine de ciencia ficción". Revista Interamericana de Bibliotecología 35, 2, pp. 169-197.

López Yepes, José (2016). Introducción al estudio de la Ética informativa en el cine. Madrid: Icadémica.

Martín Otegui, Virginia (2009). "Las bibliotecas en el cine. Aportes para el análisis de la representación de las bibliotecas en el cine". Revista General de Información y Documentación 19, pp. 61-90.

Ontoria, Antonia (1996). "La biblioteca en el cine. Realidad y ficción". Educación y Biblioteca 8, 74, pp. 46-59. 
Paz Yanes, Claudia (2002). "Bibliotecas de cine: una revisión de la imagen de las bibliotecas y los bibliotecarios en el séptimo arte (tópicos y estereotipos)". Scire 8, 2 (julio-diciembre), pp. 117-140.

\section{FUENTES DE LOS FILMES}

\section{Carátulas:}

Imbd. Disponible en: www.imbd.com.

Sinopsis de las películas citadas:

Martínez-Salanova Sánchez, Enrique. Periodismo y medios de comunicación en el cine. Películas que tienen que ver con los medios de comunicación, el mundo del periodismo y la noticia.

Disponible en: http://www.uhu.es/cine.educacion/cineyedu cacion/periodismo.htm.

Filmaffinity. Disponible en: http://www.filmaffinity.com/mx /main.html. 
Uso ético de la información: implicaciones y desafíos. La edición consta de 100 ejemplares impresos en papel cultural de 90 g. Coordinación editorial, Carlos Ceballos Sosa; revisión especializada de textos y formación editorial, Edgar Abraham Alameda Rangel; revisión de pruebas, Zyanya Benavides. Instituto de Investigaciones Bibliotecológicas y de la Información/UNAM. Se terminó de imprimir en el mes de abril de 2017, en los talleres de AGYS Alevin, S.C., Retorno de Amores, No. 14, colonia Del Valle, C.P. 03100, delegación Benito Juárez, Ciudad de México. 